WSRC-TR-2002-00330, Rev. 0

\title{
THERMODYNAMIC MODELING OF THE SRS EVAPORATORS: PART IV. INCORPORATION OF HIGH CAUSTIC ALUMINOSILICATE SOLUBILITY DATA (U)
}

C. M. Jantzen, J.M. Pareizs, and T.B. Edwards

March 15, 2003

TTP \#: SR-1-9-WT-31, Subtask D

Approved by:

W.L. Tamosaitis, Research Manager

Waste Processing Technology

Westinghouse Savannah River Company

Savannah River Site

Aiken, SC 29808

Savannah River Technology Center
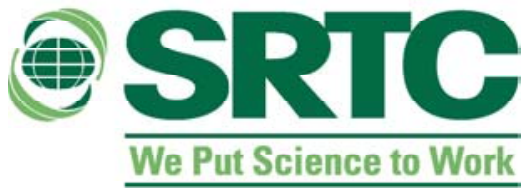

PREPARED FOR THE U.S. DEPARTMENT OF ENERGY UNDER CONTRACT NO. DE-AC09-96SR18500 
This document was prepared in conjunction with work accomplished under Contract No. DE-AC09-96SR18500 with the U. S. Department of Energy.

\section{DISCLAIMER}

This report was prepared as an account of work sponsored by an agency of the United States Government. Neither the United States Government nor any agency thereof, nor any of their employees, makes any warranty, express or implied, or assumes any legal liability or responsibility for the accuracy, completeness, or usefulness of any information, apparatus, product or process disclosed, or represents that its use would not infringe privately owned rights. Reference herein to any specific commercial product, process or service by trade name, trademark, manufacturer, or otherwise does not necessarily constitute or imply its endorsement, recommendation, or favoring by the United States Government or any agency thereof. The views and opinions of authors expressed herein do not necessarily state or reflect those of the United States Government or any agency thereof.

This report has been reproduced directly from the best available copy.

Available for sale to the public, in paper, from: U.S. Department of Commerce, National Technical Information Service, 5285 Port Royal Road, Springfield, VA 22161, phone: (800) 553-6847, fax: (703) 605-6900

email: orders@ntis.fedworld.gov

online ordering: http://www.ntis.gov/help/index.asp

Available electronically at http://www.osti.gov/bridge

Available for a processing fee to U.S. Department of Energy and its contractors, in paper, from: U.S. Department of Energy, Office of Scientific and Technical Information, P.O. Box 62, Oak Ridge, TN 37831-0062,

phone: (865)576-8401,

fax: (865)576-5728

email: $\underline{\text { reports@ adonis.osti.gov }}$ 
WSRC-TR-2002-00330, Rev. 0

WSRC-TR-2002-00330, Rev. 0

Distribution Category: Unlimited

Keywords: Evaporators, activity

diagrams, zeolite, $2 \mathrm{H}$

Evaporator

Retention: Permanent

\section{THERMODYNAMIC MODELING OF THE SRS EVAPORATORS: PART IV. INCORPORATION OF HIGH CAUSTIC ALUMINOSILICATE SOLUBILITY DATA (U)}

C. M. Jantzen, J.M. Pareizs and T.B. Edwards

Publication Date: March 15, 2003

TTP \#: SR-1-9-WT-31, Subtask D

Approved by:

W.L. Tamosaitis, Research Manager

Waste Processing Technology

Westinghouse Savannah River Company

Savannah River Site

Aiken, SC 29808

Savannah River Technology Center
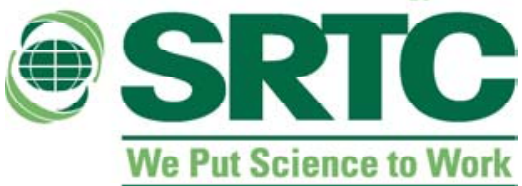

PREPARED FOR THE U.S. DEPARTMENT OF ENERGY UNDER CONTRACT NO. DE-AC09-96SR18500 
WSRC-TR-2002-00330, Rev. 0

\section{Approvals}

Carol M. Jantzen, Author, Immobilization Technology

Date

John M. Pareizs, Author, Immobilization Technology

Date

Tommy B. Edwards, Author, Statistical Consulting

Date

David T. Hobbs, Technical Reviewer, Waste Processing Technology

Date

Richard E. Edwards, Manager, HLW Process Engineering

Date

Eric J. Freed, Manager, CST Process Support

Date

W.L. Tamosaitis, Manager, Waste Processing Technology

Date 


\section{WSRC-TR-2002-00330, Rev. 0}

\section{EXECUTIVE SUMMARY}

Accumulations of two solid phases (a nitrated aluminosilicate) and sodium diuranate, in the form of scale, caused the SRS 2H Evaporator pot to become completely inoperable in October 1999. The accumulation of the sodium diuranate phase, which selectively precipitated with the aluminosilicate phase, caused criticality concerns in the $2 \mathrm{H}$ Evaporator. In order to understand the role of steady state saturation on the scale formation, solutions processed from the SRS $2 \mathrm{H}$, $2 \mathrm{~F}$, and $3 \mathrm{H}$ Evaporators were evaluated with a commercially available thermodynamic equilibrium code known as Geochemist's Workbench (GWB).

Reactive oxides, soluble silicates, and soluble aluminates in caustic solution can form a sodium aluminosilicate gel $\left(\mathrm{NAS}_{\mathrm{gel}}\right)$ at ambient temperature when the solution stoichiometry of the aluminate and silicate species is $\sim 1: 1$. The $\mathrm{NAS}_{\text {gel }}$ converts to Zeolite-A under hydrothermal conditions similar to those existing in the SRS evaporators. The nitrated-cancrinite/sodalite formed in the SRS 2H Evaporator was found to have formed from NAS gel $_{\text {and Zeolite-A. }}$ Zeolite-A and hydroxysodalite formation from NAS $_{\text {gel }}$ has also been observed in evaporators

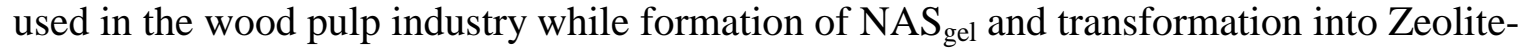
$\mathrm{A} \rightarrow$ sodalite $\rightarrow$ cancrinite has been observed in the Bayer aluminum process. Solubility data for $\mathrm{NAS}_{\text {gel }}$, Zeolite-A, nitrated sodalite, and nitrated cancrinite in SRS high caustic solutions containing nitrate, nitrite and excess $\mathrm{Al}(\mathrm{OH})_{4}{ }^{-}$were recently generated for SRS by researchers at the University of Southern Australia. The new solubility data have been incorporated into the process control model for the SRS evaporators and documented in this study.

The potential to form the $\mathrm{NAS}_{\text {gel }}$ phase in the evaporator was modeled because this phase is the primary phase from which all the other aged crystalline product species are derived. In addition, the formation of the $\mathrm{NAS}_{\text {gel }}$ phase is kinetically the most rapid step in the formation sequence [species in solution] $\rightarrow \mathrm{NAS}_{\mathrm{gel}} \rightarrow$ Zeolite-A $\rightarrow$ sodalite $\rightarrow$ cancrinite. Modeling the denser crystalline phases, which are more thermodynamically stable but less soluble than the $\mathrm{NAS}_{\text {gel, }}$ would unnecessarily constrict the solution chemistry range of the SRS evaporators. New kinetic data developed by researchers at the Pacific Northwest National Laboratory are shown to validate the use of the $\mathrm{NAS}_{\mathrm{gel}}$ precursor phase as the basis for the process control modeling.

Nominal and expanded evaporator process control models are presented in this study based on calculated $\mathrm{NAS}_{\text {gel }}$ supersaturations performed using Geochemist's Workbench. The nominal process control model covers the last 7 years of SRS evaporator operation over a narrower composition range than the expanded model. The nominal evaporator model assumes a nominal $40 \%$ evaporation (defined as $40 \%$ loss of the weight of water) at operating temperature ranges of $120-140^{\circ} \mathrm{C}$. The sensitivity of the nominal model to temperature is shown to be minimal while the sensitivity to evaporation is somewhat greater. The expanded evaporator process control model covers the wider tank farm compositional region expected to be processed in the future for the following types of evaporator operating conditions:

- 0-80 wt \% evaporation

- $100^{\circ} \mathrm{C}$ to $180^{\circ} \mathrm{C}$ 
WSRC-TR-2002-00330, Rev. 0

Both the nominal and the expanded process models are based on solubility data of the NAS gel $_{1}$ phase determined by researchers at the University of Southern Australia. The new solubility data were carefully determined in simulated SRS evaporator solutions including the following:

- solid products were "quenched" and chemically analyzed

- solutions varied from $6 \mathrm{M}$ to $12 \mathrm{M}$ caustic

- runs were reversed to demonstrate that equilibrium had been achieved

- $\quad$ once the solubility data were entered into Geochemist's Workbench, $\log (\mathrm{Q} / \mathrm{K})_{\mathrm{NAS}}$ values were calculated for the solutions at various temperatures and concentrations; values of $\sim 0$ verified that equilibrium had, indeed, been achieved

The stoichiometry of the $\mathrm{NAS}_{\text {gel }}$ phase is $\mathrm{Na}_{12} \mathrm{Al}_{12} \mathrm{Si}_{12} \mathrm{O}_{48} \bullet 27 \mathrm{H}_{2} \mathrm{O}$ in the high caustic SRS simulated evaporator solutions and not $\mathrm{Na}_{12} \mathrm{Al}_{12} \mathrm{Si}_{14} \mathrm{O}_{52} \bullet 31 \mathrm{H}_{2} \mathrm{O}$ used in previous models developed based on the data from the Bayer aluminium industry. The NAS gel was more soluble in the simulated high caustic SRS evaporator solutions than the Bayer solutions. The use of the newly generated solubility data demonstrated that the previous evaporator process control models had underestimated the importance of the $\mathrm{OH}^{-}$term in modeling due to this enhanced solubility.

The revised nominal process control model was derived which takes the form of

$$
\log (Q / K)_{N A S 120-140^{\circ} \mathrm{C} / 40 \% \text { evap }}=\begin{aligned}
& 37.4848+1.0949(12 \log [A l(M)]+12 \log [\operatorname{Si}(M)] \\
& -12 \log [O H(M)])
\end{aligned}
$$

Where $\log (Q / K)_{N A S 120-140^{\circ} \mathrm{C} / 40 \% \text { evap }}$ on the LHS of the equation is the supersaturation that will be experienced in the evaporator pot between $120-140^{\circ} \mathrm{C}$ after a $40 \%$ evaporation of water from an evaporator solution. The compositional dependencies of the initial solution concentrations to the $40 \%$ evaporation are represented by the parameters on the RHS of the equation, which are measurements taken at room temperature before evaporation. The RHS of the nominal process

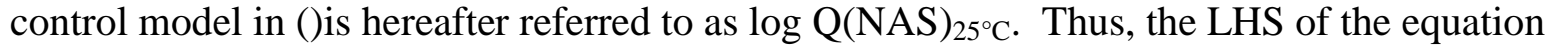
represents saturation in the evaporator after a given percent evaporation and the RHS of the equation represents the feed tank chemistry.

The nominal process control model is based on SRS evaporator feed tank data analyzed only at SRTC and is validated using an Orthogonal Latin Hypercube (OLH) statistical design of simulated evaporator solutions. The OLH for validation of the statistical process control is performed in molar composition space since the solution compositions being modeled exhibited a Gaussian distribution over the 7 year time period (1995-2002) being modeled. The OLH design created some unrealistic combinations of evaporation and sodium content. For example, the OLH may have an evaporation of $40 \%$ for a starting sodium content of $16 \mathrm{M}$. This evaporation would yield an unachievable high final sodium concentration. Therefore, a screening tool was developed to eliminate these unrealistic combinations, e.g. Max Evap $=1-\frac{N a(M)}{19}$, where $\mathrm{Na}(\mathrm{M})$ is the initial sodium content before evaporation. 


\section{WSRC-TR-2002-00330, Rev. 0}

Equations similar to the nominal process control model can be derived for various combinations of operating temperature and percent evaporation. When these equations are solved at $\log (Q / K)=0$, which represents saturation with respect to $\mathrm{NAS}_{\text {gel }}$, a family of $\log \mathrm{Q}(\mathrm{NAS})_{25^{\circ} \mathrm{C}}$

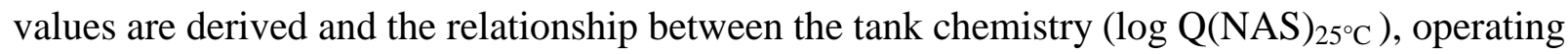
temperature and percent evaporation takes the form

$$
\log \mathrm{Q}(\mathrm{NAS})_{25^{\circ} \mathrm{C}}=-32.1114-0.1119(\% \text { Evaporation })+0.0165\left(\text { Operating Temp }{ }^{\circ} \mathrm{C}\right)
$$

where $\log \mathrm{Q}(\mathrm{NAS})_{25^{\circ} \mathrm{C}}=(12 \log [A l(M)]+12 \log [\operatorname{Si}(M)]-12 \log [O H(M)])$

The coefficients in this equation demonstrate that evaporation and operating temperature have opposite effects. Increased evaporation causes decreased solubility of components while increased temperature causes increased solubility of components. In addition, the coefficients demonstrate that evaporation is a factor of 10 more significant than operating temperature. Due to the insignificance of the temperature term, and the fact that higher temperature causes increased solubility of components, the temperature term can be eliminated from the above equation, which then becomes:

$$
\log \mathrm{Q}(\mathrm{NAS})_{25^{\circ} \mathrm{C}}=-29.9434-0.1092(\% \text { Evaporation })
$$

The above relation between $\log \mathrm{Q}(\mathrm{NAS})_{25^{\circ} \mathrm{C}}$ and percent evaporation can be used to control scaling in the SRS evaporators at a variety of temperatures if the percent evaporation can be monitored. However, this process control approach is only valid over the compositional range of solutions modeled, e.g. the historic composition range experienced between 1995 and 2002.

An expanded process control model was developed using an OLH lognormal experimental design since the composition space over the historic 28 year operational period of the tank farm (1973-2002) indicated a lognormal distribution. As with the OLH validation experimental design, the screening tool was applied to eliminate unrealistic combinations. Half of the remaining 401 data points, randomly chosen, were used to develop the expanded process control model and the remaining half were used for validation. The expanded process control model takes the form

$$
\log (Q / K)_{N A S}=\begin{aligned}
& 9.8691+13.04 \log [\operatorname{Al}(M)]+11.09 \log [\operatorname{Si}(M)]-13.51 \\
& \log [O H(M)]+15.84 \text { Density }+0.0163 \operatorname{Temp}\left({ }^{\circ} \mathrm{C}\right)
\end{aligned}
$$

The usage of the expanded process control model does not entail monitoring of the percent evaporation since the fitted coefficients of $\log \mathrm{Al}(\mathrm{M}), \log \mathrm{Si}(\mathrm{M}), \log \mathrm{OH}(\mathrm{M})$, density, and operating temperature compensate for the missing parameter because they are all related to percent evaporation.

Both the nominal and the expanded process control models have coefficients for the $\log \mathrm{Al}(\mathrm{M})$, $\log \mathrm{Si}(\mathrm{M})$, and $\log \mathrm{OH}(\mathrm{M})$ that are close to the parameters 12:12:-12 developed from the 


\section{WSRC-TR-2002-00330, Rev. 0}

thermodynamic equation governing the phase boundary between $\mathrm{NAS}_{\text {gel }}$ and $\mathrm{AlOOH}$ which in turn is governed by the stoichiometry of the $\mathrm{NAS}_{\text {gel: }}$ :

$$
12 \mathrm{Al}(\mathrm{OH})_{4}^{-}+12 \mathrm{SiO}_{2}(\mathrm{aq})+12 \mathrm{NaOH}+3 \mathrm{H}_{2} \mathrm{O} \Leftrightarrow \mathrm{Na}_{12} \mathrm{Al}_{12} \mathrm{Si}_{12} \mathrm{O}_{48} \bullet 27 \mathrm{H}_{2} \mathrm{O}+12 \mathrm{OH}^{-}
$$

When the expanded process control model is related to the past 7 years of SRS evaporator operating history it demonstrates that normal operation has been at $\log (\mathrm{Q} / \mathrm{K})_{\mathrm{NAS}}<<0$ in the undersaturated $\mathrm{NAS}_{\text {gel }}$ region, e.g. values in the -15 to -10 range for the $2 \mathrm{H}$ evaporator when it was not scaling and for the $2 \mathrm{~F}$ and $3 \mathrm{H}$ evaporators, historically. $\log (\mathrm{Q} / \mathrm{K})_{\mathrm{NAS}}$ has been in the -7 to -5 range for recent $3 \mathrm{H}$ evaporator operation.

Therefore, a $\log (\mathrm{Q} / \mathrm{K})_{\mathrm{NAS}}<0$ process control limit can be set for implementation of the expanded process control model based on operational history or a process control limit of $\log (\mathrm{Q} / \mathrm{K})_{\mathrm{NAS}}=0$ can be implemented except during process upset conditions. The limit of $\log (\mathrm{Q} / \mathrm{K})_{\mathrm{NAS}}=0$ separates the 7 years (1995-2002) of SRS Evaporator operation modeled into two populations, hereafter referred to as "normal operation" and "process upset operation."

Operation "just at saturation," e.g. $\log (\mathrm{Q} / \mathrm{K})_{\mathrm{NAS}}=0$, is an attractive approach because of the following:

- $\quad$ silicate solutions can be $>200 \%$ supersaturated at a given elevated temperature and not precipitate until the solutions are cooled

- $\quad$ precipitation of $\mathrm{NAS}_{\text {gel }}$ historically only occurred during process upset conditions, e.g. when the feed pump for the $2 \mathrm{H}$ evaporator was in the Zone of Turbidity (ZOT) and the evaporator was receiving frequent silica rich frit SME carryovers from DWPF

This demonstrates that it is only necessary to control at $\log (\mathrm{Q} / \mathrm{K})_{\mathrm{NAS}}<0$ if there are known process upsets that could cause increased $\mathrm{Si}$ such as the following:

- $\quad$ evaporator feeds exposed to silica rich frit carryovers from the DWPF Slurry Mix Evaporator

- $\quad$ evaporator feeds pumped when the feed pump was too close to the sludge or in the Zone of Turbidity (ZOT) as defined in Parts I and II of this study

- $\quad$ evaporator feeds containing high silica and/or zeolite seeds such as the HEME/HEPA digests from DWPF

- $\quad$ sludge wash water that may contain elevated levels of silica from degradation of IE-95 resin which liberates 11 moles of $\mathrm{SiO}_{2}$ for every mole of degraded resin, e.g. Tank 19 or Tank 18 wash water

Control at $\log (\mathrm{Q} / \mathrm{K})_{\mathrm{NAS}}=0$ allows credit to be taken for keeping the feed pumps 40 " above the sludge or 20"above the ZOT, so that receipt of silica rich material from the ZOT cannot occur. Due to stratification of the chemistry in the tanks, samples for process control should be taken at the height of the feed pump in feed tanks or at variable depths in tanks about to be qualified as evaporator feed. 


\section{TABLE OF CONTENTS}

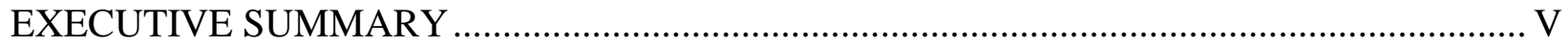

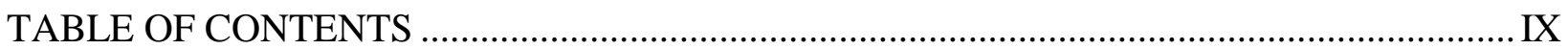

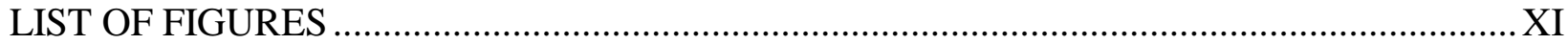

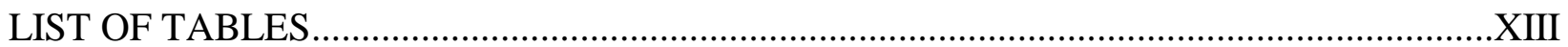

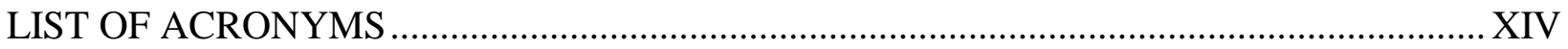

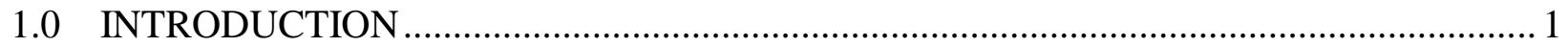

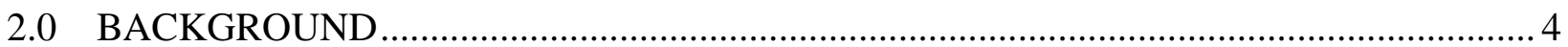

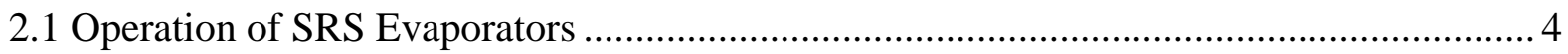

2.2 Geochemist's Workbench (GWB) ……………….................................................... 5

2.3 Orthogonal Latin Hypercube (OLH) Statistical Analysis................................................... 6

2.4 The Role of Kinetics in Thermodynamic Modeling....................................................... 8

3.0 RECENT ANALYTIC DATA AVAILABLE FOR EVAPORATOR MODELING............ 15

3.1 Availability of Analytic Data ………………............................................................. 15

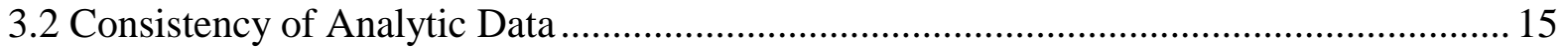

3.3 Quality of Analytic Data............................................................................................ 17

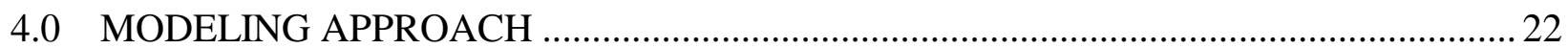

5.0 PROCESS MODELING FOR NOMINAL EVAPORATOR OPERATION …….................22

5.1 Comparison of Evaporator Models Based on Mensah vs. Ejaz ………………………....2 26

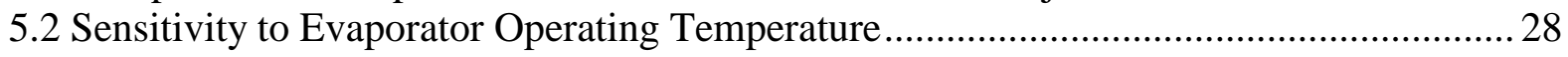

5.3 Sensitivity to Percent Evaporation …………………................................................. 31

6.0 VALIDATION OF NOMINAL PROCESS CONTROL MODEL …………........................ 34

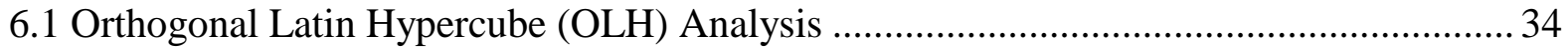

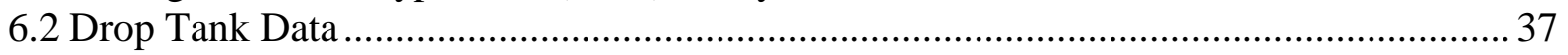

7.0 DEVELOPMENT OF AN EXPANDED EVAPORATOR PROCESS CONTROL

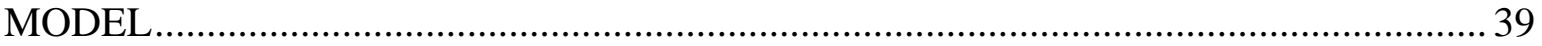

7.1 Orthogonal Latin Hypercube Design ................................................................................ 39

7.2 The OLH Expanded Evaporator Model …………….................................................... 42

7.3 Validation of the OLH Expanded Evaporator Model.......................................................... 45

7.4 Correlation of the OLH Expanded Evaporator Model to Historic Evaporator

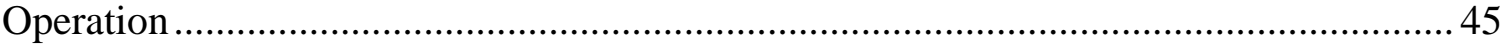

7.5 Justification for Evaporator Operation at Saturation.................................................... 48

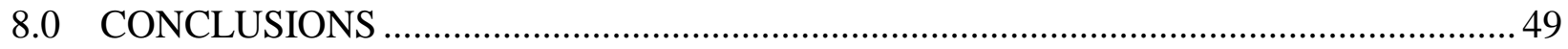


WSRC-TR-2002-00330, Rev. 0

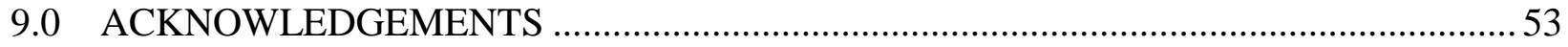

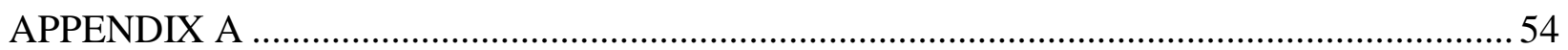

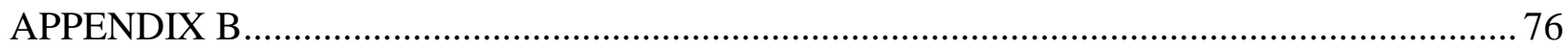

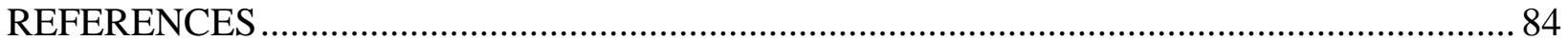


Figure 1. Scatterplot matrix for the Optimized OLH Design. 7

Figure 2. Typical formation and aging (densification) sequence of $\mathrm{NAS}_{\text {gel }} \rightarrow$ Zeolite-A $\rightarrow$ sodalite $\rightarrow$ cancrinite phases depending on the relative concentration of $\mathrm{OH}^{-}, \mathrm{Cl}^{-}$, $\mathrm{NO}_{3}{ }^{-}$, and/or $\mathrm{CO}_{3}{ }^{-}$in the solution in contact with the $\mathrm{NAS}_{\text {gel }}$ (after Gerson, et.al. $)^{20,21}$

Figure 3. Pictorial diagram showing the differences between a sol, gel, and precipitate (after references and ).

Figure 4. Overlays of the activity diagrams for NAS gel, Zeolite-A, nitrated sodalite and nitrated cancrinite showing the kinetic data of Mattigod from PNNL.

Figure 5. Time-Temperature-Transformation (TTT) diagram of the kinetic data developed by PNNL in support of SRS evaporator modeling. The phase field designations are as follows: $*=\mathrm{NAS}_{\text {gel }} ; \bullet=\mathrm{NAS} S_{\text {gel }}+$ Sodalite + Zeolite-A; $\diamond=\mathrm{NAS} S_{\text {gel }}+$ Sodalite; $\forall=\mathrm{NAS}_{\text {gel }}+$ Sodalite + Cancrinite; $\cong=\mathrm{NAS}$ gel + Zeolite- $\mathrm{A} ;+=\mathrm{Al}(\mathrm{OH})_{3}$, gibbsite; !=NAS gel + boehmite+gibbsite

Figure 6. Nominal process control model for the SRS evaporators based on the solubility data of Mensah. ${ }^{8}$ The model is based on the equilibrium between diaspore and $\mathrm{NAS}_{\text {gel }}$ represented on the activity diagrams in Part $\mathrm{I}^{3}$ and Equation 13. It provides a correlation between ambient feed tank chemistry and saturation of the feed tank solutions in the evaporator assuming a nominal $40 \mathrm{wt} \%$ evaporation at temperatures in the range of $120-140^{\circ} \mathrm{C}$.

Figure 7. Comparison of the evaporator process control model based on the data of Ejaz ${ }^{6}$ (red) generated from the Bayer alumina industry aluminosilicate solubility and the data of Mensah et al. ${ }^{8}$ (blue) generated in SRS simulated evaporator solutions

Figure 8 Shift of the $\mathrm{NAS}_{\text {gel- }}$-diaspore boundary based on the solubility data of the $\mathrm{NAS}_{\mathrm{gel}}$ in SRS simulated evaporator solutions as measured by Mensah et. al. (solid lines) ${ }^{8}$ compared to the solubility boundary calculated using the data of Ejaz (dashed line). Diagram generated with composition of evaporator solution FTF-046.

Figure 9. Metastable extension of the equilibrium between $\mathrm{AlOOH}$ and $\mathrm{NAS}_{\text {gel }}$ into the stability field of $\mathrm{NaAlO}_{2}$ for feed tank samples HTK-480-482 (red) and drop tank samples HTK-505-507 (blue) at $180^{\circ} \mathrm{C}$

Figure 10. Relation of $\log \mathrm{Q}(\mathrm{NAS})_{25^{\circ} \mathrm{C}}$ to percent evaporation and evaporator operating temperature. 
Figure 11. Gaussian distribution of $\mathrm{OH}^{-}(\mathrm{M})$ and $\mathrm{Na}^{+}$calc $(\mathrm{M})$ in feed tank solutions used to define the nominal process model. The red line represents an ideal Gaussian distribution.

Figure 12 Assessment of the nominal process control model (Equation 13) to the OLH validation data.

Figure 13. Correlation between the nominal process control model developed based on SRS evaporator feed tank data between 1995-2002 (Equation 13) and a set of simulated evaporator solutions generated by a composition and temperature space filling OLH design (Equation 27).

Figure 14. Bias in supersaturation between drop tank and feed tank data.

Figure 15. Assessment of the nominal process control model (Equation 13) to the drop tank validation data.

Figure 16. Lognormal distribution of tank farm solutions over 28 years (1973-2001).

Figure 17. Bivariate Fit of $\log (\mathrm{Q} / \mathrm{K})_{\mathrm{NAS}}$ versus $\log \mathrm{Q}(\mathrm{NAS})_{25^{\circ} \mathrm{C}}$ for the optimized Orthogonal Latin Hypercube model spanning $40^{\circ} \mathrm{C}-180^{\circ} \mathrm{C}$ and $0-80 \%$ evaporation. Note colors are associated with varying $\mathrm{OH}^{-}$concentrations, warmer colors are lower $\mathrm{OH}^{-}$concentration than cooler colors.

Figure 18 Significance (leverage) of the parameters in Equation 29.

Figure 19. Assessment of the expanded process control model (Equation 30) to the GWB predicted values.

Figure 20. Operational History of SRS Evaporators assessed using Equation 30. .................. 46

Figure A-1.Polynomial fit of Tank Solution Density to Sodium Molarity.................. 55

Figure A-2.Comparison Between Measured (X) and Predicted (-) Denisty.............. 56

Figure A-3.Histogram Showing the Percent Difference Between Predicted and Measured Densities........................................................ 57

Figure B-1.Comparison of $\log \mathrm{K}$ Values Used in GWB.......................... 81

Figure B-2.Calculated $\log \mathrm{Q} / \mathrm{K}$ values for Mensah NAS ${ }_{\text {gel }}$ Saturated Solutions.............. 82 


\section{LIST OF TABLES}

Table I. Analytic data from SRTC for Evaporator Feed Tank 32 Used For Modeling ....... 19

Table II. Analytic data from SRTC for Evaporator Feed Tanks 43 and 26 Used For Modeling (Continued).

Table III. Analytic data from SRTC for Evaporator Drop Tanks 30, 46, 38 Used For Model Validation ......

Table IV. Sensitivity of $\log (\mathrm{Q} / \mathrm{K})_{\mathrm{NAS}}$ at Varying Evaporator Operating Temperatures 31

Table V. Sensitivity of $\log (\mathrm{Q} / \mathrm{K})_{\mathrm{NAS}}$ at Varying Evaporations ................................................ 32

Table VI. Sensitivity of Aluminosilicate Supersaturation to Evaporation and Temperature .......33

Table VII. Ranges Modeled in Section 5.0 (Feed Tank Data from 1995-2002) ............................ 34

Table VIII. Tank Farm Bounding Regions Including Logarithmic Transformations Used in the OLH Statistical Analysis

Table IX. Calculations of $\log (\mathrm{Q} / \mathrm{K})_{\mathrm{NAS}}$ for Selected Samples of Model Data From Equation 30

Table A-1. Measured Tank Solution Densities and Chemical Compositions .68

Table B-1. Initial Solution Composition and Equilibrium Aluminum and Silicon Compositions for $\mathrm{NAS}_{\text {gel }}$ Solubility Experiments.

Table B-2. Molar $\mathrm{NAS}_{\mathrm{gel}}$ Equilibrium Compositions .78

Table B-3. Calculated Solution Density, Solute Mass, and Composition in Molality for NAS $\mathrm{gel}_{\mathrm{gl}}$ Equilibrium Solutions

Table B-4. Calculated log K Values for NAS gel Solutions. 80

Table B-5. NAS $S_{\text {gel }} \log$ K Values for Input into GWB Thermodynamic Database. 
WSRC-TR-2002-00330, Rev. 0

\section{LIST OF ACRONYMS}

ACT-2: $\quad$ ACTivity Diagram Subroutine in GWB

DOE: $\quad$ United States Department of Energy

GDL: $\quad$ Gravity Drain Line

GWB: $\quad$ The Geochemist's Workbench Software

HLW: $\quad$ High Level Waste

LHS: $\quad$ Left Hand Side

LLNL: $\quad$ Lawrence Livermore National Laboratory

NAS: $\quad$ Sodium Aluminosilicate gel

OLS: $\quad$ Ordinary Least Squares

OLH: $\quad$ Orthogonal Latin Hypercube

ORNL: $\quad$ Oak Ridge National Laboratory

PNNL: Pacific Northwest National Laboratory

REACT: $\quad$ Reaction Path Subroutine in GWB

RHS: $\quad$ Right Hand Side

RMSE: $\quad$ Root Mean Square Error

RW-0333P: DOE Level of Quality Assurance

SME: $\quad$ Slurry Mix Evaporator

SRS: $\quad$ Savannah River Site

SRTC: $\quad$ Savannah River Technology Center

TDS: $\quad$ Total Dissolved Solids

TTT: $\quad$ Time-Temperature-Transformation

USA: $\quad$ University of Southern Australia

VDS: $\quad$ Variable Depth Samples

WSRC: Westinghouse Savannah River Company

ZOT: $\quad$ Zone of Turbidity 


\title{
THERMODYNAMIC MODELING OF THE SRS EVAPORATORS: PART IV. INCORPORATION OF HIGH CAUSTIC ALUMINOSILICATE SOLUBILITY DATA (U)
}

\author{
C. M. Jantzen, J.M. Pareizs, and T.B. Edwards \\ Savannah River Technology Center \\ Westinghouse Savannah River Company \\ Aiken, South Carolina 29808
}

\subsection{INTRODUCTION}

Accumulations of two solid phases (nitrated aluminosilicates $f$ and sodium diuranate*) formed scale deposits in the Savannah River Site (SRS) 2H Evaporator system. ${ }^{1,2}$ The sodium aluminosilicate (NAS) scale deposits caused the evaporator pot to become inoperable in October 1999. Accumulations of the diuranate phase have caused criticality concerns in the SRS $2 \mathrm{H}$ Evaporator. In Part I of this study, ${ }^{3}$ thermodynamically derived activity diagrams, also known as stability diagrams, were used on historic $2 \mathrm{H}$ feed tank (Tank 43) and drop tank (Tank 38) chemistries in order to understand the effects of tank chemistry on solids formation in the $2 \mathrm{H}$ Evaporator system. Evaluation of the 2F feed tank (Tank 26) and drop tank (Tank 46) chemistries evaluated in Part I of this study showed that the SRS 2F Evaporator system had not and was not near saturation with respect to aluminosilicate scale. In order to ensure that similar deposits had not and were not depositing in the SRS 3H Evaporator system, a similar evaluation was performed specific to the feeds processed from Tank 32 (feed tank) and Tank 30 (drop tank) in Part II of this study.

A commercially available computer code, Geochemist's Workbench (GWB), was modified to include solubility data for species found in SRS evaporators in high ionic strength solutions. Activity diagram representation was used to evaluate whether an evaporator feed tank composition fell in the formation (stability) field of the undesirable aluminosilicate species, e.g. was a given evaporator solution saturated or supersaturated with respect to the undesirable aluminosilicate species that caused scaling. The operational history of all the SRS evaporators was shown to coincide with the phase fields on the activity diagrams. The SRS 2H Evaporator was inoperable and scaled periodically when the solutions fed to the evaporator were saturated with respect to the sodium aluminosilicate gel $\left(\mathrm{NAS}_{\mathrm{gel}}\right)$ phase. The $\mathrm{SRS} 2 \mathrm{H}, 2 \mathrm{~F}$, and $3 \mathrm{H}$ Evaporators were operational as long as the solutions being processed were saturated with respect to aluminum hydroxide phases such as gibbsite $\left(\mathrm{Al}(\mathrm{OH})_{3}\right)$ or diaspore $(\mathrm{AlOOH})$, since the kinetics of formation of the aluminum hydroxides is on the order of 2 weeks while the evaporator residence times are on the order of 8-12 hours.

\footnotetext{
${ }^{f}$ a mixture of nitrated cancrinite, $\mathrm{Na}_{8} \mathrm{Al}_{6} \mathrm{Si}_{6} \mathrm{O}_{24}\left(\mathrm{NO}_{3}\right)_{2} \bullet 4 \mathrm{H}_{2} \mathrm{O}$, and nitrated sodalite, $\mathrm{Na}_{8} \mathrm{Al}_{6} \mathrm{Si}_{6} \mathrm{O}_{24}\left(\mathrm{NO}_{3}\right)_{2}$

${ }^{*} \mathrm{Na}_{2} \mathrm{U}_{2} \mathrm{O}_{7}$
} 


\section{WSRC-TR-2002-00330, Rev. 0}

Modeling the deposition of the aluminosilicates and sodium diuranate in the SRS evaporators entailed calculations in the complex Na-N-Si-Al-U- $\mathrm{H}_{2} \mathrm{O}$ system at elevated temperatures and at high ionic strengths (I 8.5). Modeling accuracy was evaluated against the following parameters:

- quality of the chemical data available from the feed and drop tanks

- how representative the analytic dip samples from the feed tank are of the feed actually entering the evaporator due to tank chemistry stratification

- the quality of the solution density approximations used to convert from molar to molal units

- quality of the approximations that must be made to determine the activity coefficients for high ionic strength solutions.

The quality of the solution density approximations is discussed in Appendix A. The quality of the approximations made to determine the activity coefficients are discussed in Part I of this study. ${ }^{3}$ The quality of the chemical data available for the SRS $2 \mathrm{H}$ and $2 \mathrm{~F}$ Evaporators between 1992 and 2000 is also discussed in Part $\mathrm{I}^{3}$ while the quality of the chemical data for the SRS $3 \mathrm{H}$ Evaporator for the same time period is discussed in Part II. ${ }^{4}$ The quality of tank data analyzed between 2001 and 2002 is discussed in Part III. ${ }^{5}$ The quality of all the data used in the development of a process control model is discussed in this study (Part IV).

A process control strategy was developed in Part I of this study ${ }^{3}$ to relate the ambient temperature chemistry in an evaporator feed tank to the saturation of that feed in the evaporator pot at elevated temperature during a nominal $40 \mathrm{wt} \%$ evaporation. In Part $\mathrm{III}^{5}$ of this study the usage of the process control strategy was expanded to various temperatures $\left(120-180^{\circ} \mathrm{C}\right)$ and evaporations (0-60\%) based on the extrapolated (from $4 \mathrm{M} \mathrm{NaOH}$ to $8 \mathrm{M} \mathrm{NaOH}$ ) solubility data of Bayer aluminum industry liquors ${ }^{6}$ and wood pulp industry liquors. ${ }^{7}$

In this study (Part IV) the process control approach is modified from that presented in Parts I, ${ }^{3}$ $\mathrm{II}^{4}$ and $\mathrm{III}^{5}$ of this study as follows:

- $\quad$ solubilities of all of the sodium aluminosilicate phases $\left(\mathrm{NAS}_{\mathrm{gel}}\right.$, Zeolite-A, nitrated sodalite and nitrated cancrinite) as measured by Mensah et. al. ${ }^{8}$ in simulated SRS Evaporator liquors from 3-12M NaOH are added to the GWB database replacing the aluminosilicate solubility data from the Bayer aluminum industry and the data from the wood pulp industry (see Appendix B and Part $\mathrm{V}^{9}$ )

- the analyzed SRS evaporator feed tank data are used to develop a nominal process control model at $40 \%$ evaporation and operation between $120-140^{\circ} \mathrm{C}$

- the form of the model, in terms of solution chemistry, is shown to be dependent on the stoichiometry of the $\mathrm{NAS}_{\text {gel }}$ phase as shown in Parts I, II, and III of this study

- $\quad$ variable depth sample data analyzed at SRTC are used exclusively in modeling

-- F-Area laboratory data were shown to be biased high with respect to Si due to high dilution of the solutions being analyzed ${ }^{3,4}$ 
WSRC-TR-2002-00330, Rev. 0

-- F-Area laboratory data were shown to be biased low with respect to $\mathrm{Al}$ since detection limit values were being measured when high $\mathrm{Al}$ canyon waste was being fed $^{3}$

-- the drop tank data are shown to be lower in concentration with respect to the feed tank data since salts such as $\mathrm{NaNO}_{3}, \mathrm{NaAlO}_{2}$, and aluminosilicates crystallize in the drop tank

- $\quad$ the process control model derived in Part I and Part III is shown to underestimate the importance of the $\mathrm{OH}^{-}$concentration since the newly measured solubility of the NAS phases is shown to be a strong function of the $\mathrm{OH}^{-}$concentration ${ }^{8}$

- the nominal process control model is validated using a set of statistically designed orthogonal latin hypercube (OLH) simulated evaporator solutions which lie within the compositional range of the tank data modeled in this study

- the effects of variations in temperature and evaporation are demonstrated on the nominal process control model using the SRS feed tank data measured by SRTC

- an expanded process control model is developed to include evaporations between $0 \%$ and $80 \%$ and temperatures between $120-180^{\circ} \mathrm{C}$ based on a set of statistically designed orthogonal latin hypercube (OLH) solutions which lie within the broader compositional range of the tank data being considered for future processing in the SRS $2 \mathrm{~F}$ and $3 \mathrm{H}$ evaporators

- the process control model can then be expressed as a function of the solution concentrations $(\log [\mathrm{Al}], \log [\mathrm{Si}], \log [\mathrm{OH}])$ in the tank, operating temperature of the evaporator, and final percent evaporation

- alternatively the process control model can be expressed as a function of the solution concentrations $(\log [\mathrm{Al}], \log [\mathrm{Si}], \log [\mathrm{OH}])$ in the tank, operating temperature of the evaporator, and final evaporator liquor density

- the form of the model, in terms of solution chemistry, is dependent on the stoichiometry of the NAS $\mathrm{gel}_{\text {pl }}$ phase consistent with the process models developed in Parts I, II, and III of this study

- the expanded OLH process model is then tied to SRS evaporator operating history

Validation of the GWB calculational approach in simple one component systems and in the complex Na-N-Si-Al-U- $\mathrm{H}_{2} \mathrm{O}$ system, based on the new aluminosilicate solubility data, ${ }^{8}$ is discussed in Part $\mathrm{V}^{9}$ of this study. The validation of the basis for the SRS evaporator process control model, the activity diagrams, is also discussed in Part $\mathrm{V}^{9}$ of this study. 


\subsection{BACKGROUND}

\subsection{Operation of SRS Evaporators}

For 40 years, the SRS tank farm evaporators have run with only occasional operational problems, e.g., salt $\left(\mathrm{NaNO}_{3}\right)$ buildup has caused difficulty in draining evaporators but these deposits are water soluble and easily removed by flushing with hot water. The SRS $2 \mathrm{~F}$ and $3 \mathrm{H}$ Evaporators continue to operate with only occasional salt buildup. However, operation of the SRS $2 \mathrm{H}$ evaporator had become problematic due to the formation of aluminosilicate scale between 1997 and 1999.

A new 2H Evaporator pot was installed and began receiving waste in January 1996. From mid 1996 until August 1997 the SRS 2H Evaporator was increasingly hard to control. When the evaporator was shut down in August 1997 for cleaning, deposits of the sodium aluminosilicate and sodium uranate phases were found in the gravity drain line (GDL). ${ }^{10}$ The GDL was pressure washed in the direction of the drop tank. The line remained clean and the evaporator showed minimal deposits on the walls or in the lines from August 1997 to June 1998. In June 1998 the GDL needed to be pressure washed a second time and deposits were observed in the evaporator cone, on the vessel walls and on the warming tubes. The GDL was pressure washed in the direction of the evaporator and in the direction of the drop tank to ensure that it was clean. Operation continued, with difficulty, from June 1998 until October 1999, when the evaporator was shut down. At this time, significant accumulations of the aluminosilicate scale and sodium diuranate deposits were found on many of the exposed surfaces of the evaporator pot. The scale in the $2 \mathrm{H}$ Evaporator was cleaned using a depleted uranyl nitrate solution in August $2001^{11}$ and began operating again in October 2001.

Several important changes have been made in the handling of wastes entering the SRS evaporators in the last decade. 'Prior to the mid 1990's, high activity waste was stored for $>1$ year before being processed in the evaporators so that the short lived radionuclides could decay before waste was concentrated. This also allowed any solids or colloidal species in the wastes to settle to the bottom of the tank before being processed. When the SRS reactors shut down and wastes were less radioactive, the one year hold strategy was no longer required.

In addition, the evaporators discharged to alternate drop tanks. When one drop tank was filled it was left to settle, and cool, and a second drop tank was used. Typically recycles to the feed tank were made from the passive drop tank and not from the active drop tank. This allowed any particulates or colloids in a given drop tank to settle before being recycled to the feed tank again for further concentration. The active/passive drop tank practice had to be discontinued in the early 1990's since there was no longer enough salt drop space in the concentrate receipt tanks.

In 1997, the $1^{\text {st }}$ inter-area waste transfers were made between the SRS H-area and the SRS F-area waste tanks for the purpose of volume reducing the waste. This allowed co-mingling of wastes of different chemistries.

* Synopsis by Kent Gilbreath, Mark Mahoney, and Thomas Caldwell (May, 2001) 


\section{WSRC-TR-2002-00330, Rev. 0}

More recently, a decision was made to evaporate canyon and back-log waste in the $2 \mathrm{~F}$ evaporator for initial salt separation. This occurs when the hydroxide molarity exceeds 6-8M. Then the desalted liquor is routed to the $3 \mathrm{H}$ evaporator for final dehydration, which can drive the hydroxide molarity above $12 \mathrm{M}$

These changes in operational strategy and co-mingling of waste have caused concerns that the aluminosilicate scaling problems experienced with the operation of the SRS 2H Evaporator could now become system wide. Thus a process control strategy was developed ${ }^{3}$ using Geochemist's Workbench (GWB) to prevent aluminosilicate scale formation in the SRS evaporators. Control of the aluminosilicate scale formation controls any criticality concerns caused by the adherent sodium diuranate, which is partially enriched ${ }^{235} \mathrm{U}$.

\subsection{Geochemist's Workbench (GWB)}

The Geochemist's Workbench (GWB) database was modified to include various solids including stable and metastable aluminosilicate minerals such as Zeolite-A, nitrated-sodalite, nitratedcancrinite, and $\mathrm{NAS}_{\text {gel }}$ (see Appendix B and Reference 9). Modifications to the solid aluminate species had previously been made as well. ${ }^{3}$ The solubility data incorporated into the database for the aluminosilicate and aluminate species had been measured at high $\mathrm{Na}$ molarity which then allowed the GWB code to be used for modeling solutions such as those in the SRS evaporators. In addition the GWB software has the following attributes:

- ability to estimate activity coefficients for high ionic strength solutions such as those in the evaporator

- ability to improve the basis upon which the activity coefficients are estimated

- usage of Lawrence Livermore National Laboratory (LLNL) extensive database for minerals and aqueous species used to model the performance of waste forms in the High Level Waste (HLW) Repository

- includes sodium diuranate and aqueous uranate species

- ability to calculate the relative stability of multiple solid phases simultaneously

- ability to graphically represent the relative stability of multiple phases in terms of three parameters simultaneously on activity or stability diagrams, e.g. Si, Al, and $\mathrm{pH}$ of a solution

- ability to perform polythermal reaction paths, e.g. reaction path can vary temperature linearly from an initial to a final value

- ability to simulate evaporation by removing a percentage of the water from the calculation, e.g. base the calculation on $0.6 \mathrm{~kg}$ of water rather than on the default of $1 \mathrm{~kg}$ of water for a simulated $40 \mathrm{wt} \%$ evaporation

- ability to calculate a supersaturation index for a given solid phase expressed as a ratio of the reaction quotient $(\mathrm{Q})$ over the solubility product $(\mathrm{K})$, e.g. $\log (\mathrm{Q} / \mathrm{K})$

- ability to calculate the amount of the solid phase (in $\mathrm{g}_{\text {(solid) }} / \mathrm{kg}_{\text {(soln) }}$ ) that will form at the given supersaturation if precipitation to equilibrium proceeds.

\footnotetext{
¥HLW System Plan, Rev. 12
} 
WSRC-TR-2002-00330, Rev. 0

Two subroutines in GWB were used to model the precipitation of solids in the complex Na-N-Si$\mathrm{Al}-\mathrm{U}-\mathrm{H}_{2} \mathrm{O}$ system pertinent to the SRS 2H Evaporator; e.g. REACT and ACT2. The REACT subroutine models equilibrium states and processes of solids in equilibrium with aqueous fluids. The program calculates the following:

- equilibrium distribution of aqueous species in a fluid

- the fluid's saturation state with respect to mineral phases

- the fugacities of the gases dissolved in the fluid

During the process control modeling of scale formation in SRS evaporators only the REACT subroutine was used. All mineral formation (precipitation) was suppressed so that a saturation index $(\log \mathrm{Q} / \mathrm{K})$ could be calculated. Positive values of $\log (\mathrm{Q} / \mathrm{K})$ are supersaturated while negative values are undersaturated with respect to the solid phase that could precipitate.

\subsection{Orthogonal Latin Hypercube (OLH) Statistical Analysis}

The statistical perspective of design problems involving computer experimentation, such as GWB, has been explored in references $12,13,14,15$. These references identify and discuss the unique aspects of this type of design and analysis problem. A method for generating Orthogonal Latin Hypercube designs (OLHs)* and their advantages for such problems are presented in Reference 15. An advantage of a Latin Hypercube approach is that it facilitates each of the input variables having all portions of its range represented. ${ }^{15}$ Thus, the approach provides a "spacefilling" (for the factor space of interest, i.e., the concentrations, temperature, and percent evaporation) set of design points. Also, the estimates of linear effects of all factors are uncorrelated with each other, and the orthogonal Latin hypercube designs "guarantee that the estimates of quadratic effects and bilinear interaction effects are uncorrelated with estimates of linear effects. However, the estimates of quadratic and bilinear interaction effects are correlated with each other." 15

From Reference 15, an OLH consisting of $\mathrm{n}$ rows can be constructed when $\mathrm{n}$ is a power of 2 or a power of 2 plus 1 (i.e., $2^{\mathrm{m}}$ or $2^{\mathrm{m}}+1$ ). A method is provided in Reference 15 for constructing and optimizing such an OLH with $2 \mathrm{~m}-2$ columns. The value of $2 \mathrm{~m}-2$ must be equal to or greater than the number of factors of interest. A value of 9 was used for $m$ (with $2 \mathrm{~m}-2=16$, which is greater than the 14 factors used for this study. ${ }^{f}$ A value of $m=9$ leads to a value for $n$ of 512 or 513 . For this design, a value of 513 was selected; thus, the interval of possible values for each input was divided into 513 equal sub-intervals.

Following the guidance provided in Reference 15, a minimax criterion was applied to random permutations of the design to provide a test matrix where the minimum Euclidean distance

* This class of orthogonal Latin hypercubes preserves orthogonality among columns, i.e., any two columns $\mathbf{u}$ and $\mathbf{v}$ of the OLH satisfy $\mathbf{u}^{\mathrm{T}} \mathbf{v}=0$ where $\mathbf{u}^{\mathrm{T}}$ is the transpose of $\mathbf{u}$.

$f \quad$ The 14 factors were derived from the 16 parameters shown in Figure 1 by combining the concentrations nitrate with nitrite as nitrate and carbonate with oxalate as carbonate. This was done since GWB can only handle one nitrogen and one carbon species as input at a time. The 14 parameters included 12 composition parameters, temperature, and percent evaporation 
between any pair of design vectors is a maximum. Such an approach was used to generate the test matrix (or experimental design) to support this study. Figure 1 provides an illustration of the space filling and pairwise orthogonality of the resulting test matrix used in this study with concentrations expressed as the molar concentrations. Brown ${ }^{16}$ provides the details of the design approach.

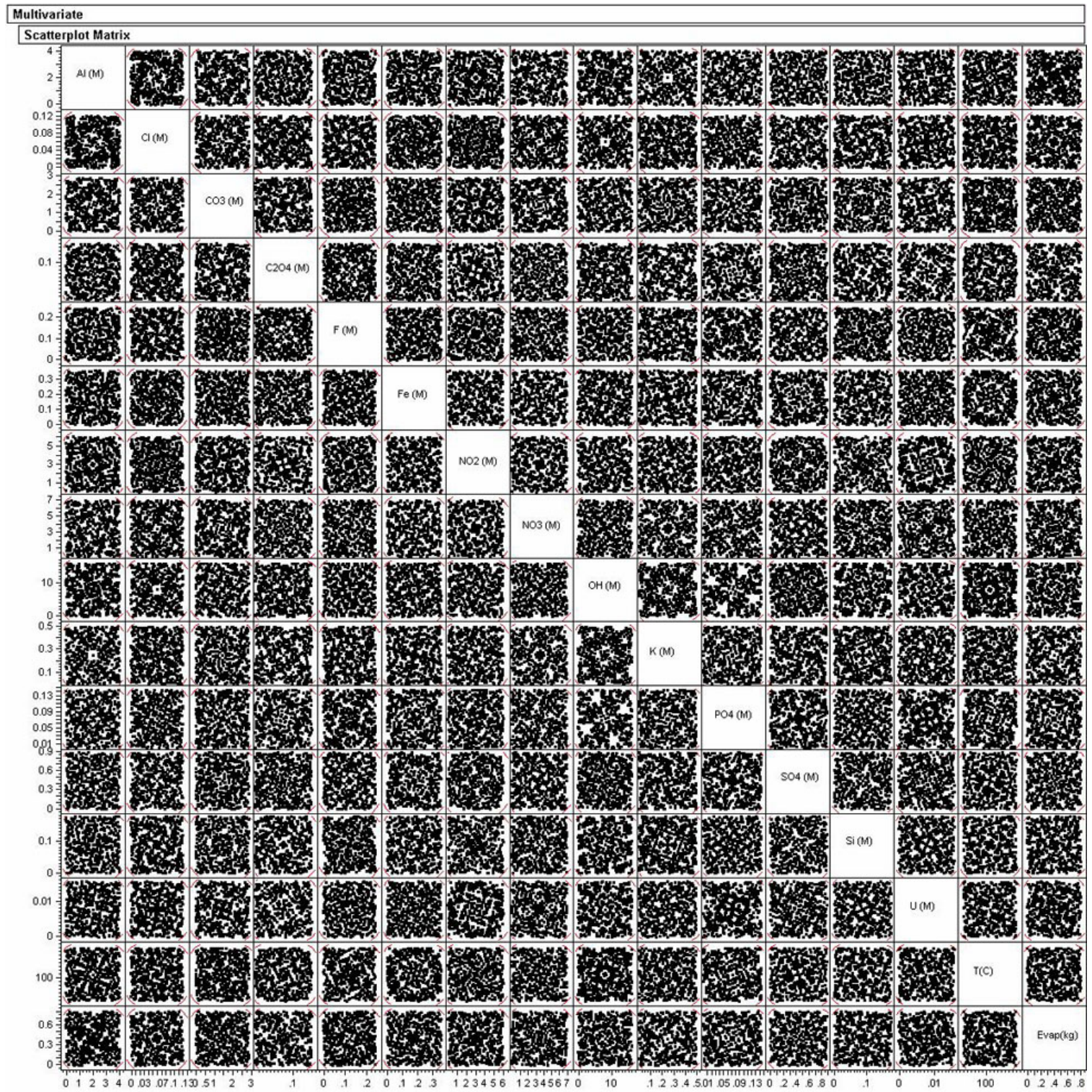

Figure 1. Scatterplot matrix for the Optimized OLH Design. 
WSRC-TR-2002-00330, Rev. 0

\subsection{The Role of Kinetics in Thermodynamic Modeling}

Thermodynamic modeling, when applied to processes that operate for relatively short time durations, is considered to be thermodynamically at steady state with respect to whatever phase is precipitating. Therefore, the kinetics of the formation of the deposits must be understood to determine which steady state phase is the appropriate phase(s) to model. Nitrated sodalites and nitrated cancrinite were found in the SRS evaporators. However, these phases are known to age in aqueous environments by dewatering and densification from a structurally related phase known as Zeolite-A. In turn, the Zeolite-A structure is known to form by any of the following mechanisms:

- from a gel process where the reactants are reactive oxides, soluble silicates, and soluble aluminates in a caustic solution (Figure 2)

- from conversion of clay minerals (specifically kaolin and meta-kaolin) in the presence of soluble silicates and caustic

- by reaction of silica sols, natural $\mathrm{SiO}_{2}$, amorphous minerals, and volcanic glass in the presence of caustic (Figure 3 ). ${ }^{3}$

The gel reactions from solution and/or the silica sol reactions are the most significant of these mechanisms for SRS evaporator modeling although small traces of clay minerals could be introduced via the process water used in the evaporators. The gel reaction from solution assumed in this study takes the form:

\section{Equation 1}

$$
\begin{aligned}
& \mathrm{NaOH}(\mathrm{aq})+\mathrm{NaAl}(\mathrm{OH})_{4}(\mathrm{aq})+\mathrm{Na}_{2} \mathrm{SiO}_{3}(\mathrm{aq}) \stackrel{25^{\circ} \mathrm{C}}{\longrightarrow} \\
& {\left[\mathrm{Na}_{\mathrm{a}}\left(\mathrm{AlO}_{2}\right)_{\mathrm{b}}\left(\mathrm{SiO}_{2}\right)_{\mathrm{c}} \bullet \mathrm{NaOH} \bullet \mathrm{H}_{2} \mathrm{O}\right]_{\mathrm{gel}} \stackrel{25-175^{\circ} \mathrm{C}}{\text { hydrothernal }} \longrightarrow \mathrm{Na}_{\mathrm{x}}\left[\left(\mathrm{AlO}_{2}\right)_{\mathrm{x}}\left(\mathrm{SiO}_{2}\right)_{\mathrm{y}}\right] \bullet \mathrm{mH}_{2} \mathrm{O}}
\end{aligned}
$$

Formation from silica sols would substitute an $\equiv \mathrm{Si}-\mathrm{OH}$ (silanol) term into Equation 1 instead of $\mathrm{Na}_{2} \mathrm{SiO}_{3}(\mathrm{aq})$.

Zeolites are synthesized industrially from solution using the gel process shown in Equation 1 . Upon mixing sodium silicate and sodium aluminate at high $\mathrm{pH}$, an amorphous sodium aluminosilicate gel $\left(\mathrm{NAS}_{\mathrm{gel}}\right)$ phase forms. Transformation of the gel to the zeolite can take hours or days depending upon the synthesis conditions. Industrial synthesis of solid Zeolite-A involves precipitation from solutions of $4.0 \mathrm{M} \mathrm{NaOH}$ to keep the crystallization times short and allow effective recycling of the excess $\mathrm{NaOH}^{17}$

Gels are amorphous, as they are colloids in which the disperse phase has combined with the continuous phase to produce a semisolid material such as a jelly. ${ }^{18}$ As a gel dewaters or ages, it will form a denser gel and/or a crystalline solid phase. This is independent of the route of formation of the gel. Whether the $\mathrm{NAS}_{\text {gel }}$ forms from solution via a hydrogel process or whether 
WSRC-TR-2002-00330, Rev. 0

it forms from a sol (solid particles in liquid) ${ }^{19}$ via a sol-gel process, the aging sequence of the $\mathrm{NAS}_{\text {gel }}$ to denser sodalite and still denser cancrinite species will typically follow an aging path such as that shown in Figure 2 according to Barnes, Mensah and Gerson ${ }^{20}$ and Gerson and

Zheng. ${ }^{21}$ Note that the densification of the phases agrees with the following literature:

- Mensah, et. al. ${ }^{8}$ made phase pure $\mathrm{NAS}_{\mathrm{gel}}$, Zeolite-A, nitrated sodalite, and nitrated cancrinite and then measured the solubility in SRS-type evaporator solutions: the chemically analyzed stoichiometry of the phases are

$$
\begin{array}{ll}
\mathrm{NAS}_{\text {gel }} & 1 \mathrm{Na}_{2} \mathrm{O}: 1 \mathrm{Al}_{2} \mathrm{O}_{3}: 2 \mathrm{SiO}_{2}: 4.5 \mathrm{H}_{2} \mathrm{O} \\
\text { Zeolite-A } & 1 \mathrm{Na}_{2} \mathrm{O}: 1 \mathrm{Al}_{2} \mathrm{O}_{3}: 2 \mathrm{SiO}_{2}: 4.5 \mathrm{H}_{2} \mathrm{O}
\end{array}
$$

Nitrated Sodalite $1 \mathrm{Na}_{2} \mathrm{O}: 1 \mathrm{Al}_{2} \mathrm{O}_{3}: 2 \mathrm{SiO}_{2}: 0.65 \mathrm{NaNO}_{3}: 1.17 \mathrm{H}_{2} \mathrm{O}$

Nitrated Cancrinite $1 \mathrm{Na}_{2} \mathrm{O}: 1 \mathrm{Al}_{2} \mathrm{O}_{3}: 2 \mathrm{SiO}_{2}: 0.67 \mathrm{NaNO}_{3}: 0.83 \mathrm{H}_{2} \mathrm{O}$

- Bayer $^{22}$ and Ejaz ${ }^{6}$ found that the NAS gels would transform to Zeolite-A. Ejaz experimentally determined the composition of the precursor gel at $\mathrm{NaOH}$ concentrations of $3-4.5 \mathrm{M}$ to be $0.93 \mathrm{Na}_{2} \mathrm{O}: 1 \mathrm{Al}_{2} \mathrm{O}_{3}: 2.32 \mathrm{SiO}_{2}: 5.15 \mathrm{H}_{2} \mathrm{O}$.

- Barrer $^{22}$ found that the NAS gels would transform to Zeolite-A at $\mathrm{pH}$ values $>10$ in 23 hours at $110^{\circ} \mathrm{C}$ (the approximate temperature of the SRS evaporators)

- Buhl and Lons ${ }^{23}$ showed that nitrated sodalite and nitrated cancrinite could best be made by starting with a Zeolite-A precursor in concentrated $\mathrm{NaOH}$ at various temperatures

- Wilmarth ${ }^{24}$ showed that the Zeolite-A forms as a precursor but the nitrated cancrinite forms on the order of $3-5$ hours at $110^{\circ} \mathrm{C}$ in simulated $2 \mathrm{H}$ Evaporator solutions

- Gasteiger et al. ${ }^{7}$ found that hydroxysodalite $\mathrm{Na}_{8}\left[\mathrm{Al}_{6} \mathrm{Si}_{6} \mathrm{O}_{24}\right](\mathrm{OH})_{2} \bullet\left(1.5 \mathrm{H}_{2} \mathrm{O}\right)$ and sodalite $\left(\mathrm{Na}_{8}\left[\mathrm{Al}_{6} \mathrm{Si}_{6} \mathrm{O}_{24}\right](\mathrm{Cl})_{2}\right)$ formation was $>99 \%$ complete in 24 hours at $95^{\circ} \mathrm{C}$ and that the sodalites formed via a Zeolite-A precursor

- Subotic, et. al. ${ }^{25}$ demonstrated that aluminosilicate gels that have a $\mathrm{Si} / \mathrm{Al}=1$ form Zeolite-A at lower $\mathrm{NaOH}$ concentrations in solution at $85^{\circ} \mathrm{C}$ which then transforms into hydroxysodalite; at higher $\mathrm{NaOH}$ concentrations the gel can transform into hydroxysodalite without the Zeolite-A precursor formation

- Bosnar and Subotic ${ }^{26}$ demonstrated that Zeolite-A forms from an amorphous aluminosilicate precursor $\left(1.03 \mathrm{Na}_{2} \mathrm{O} \cdot \mathrm{Al}_{2} \mathrm{O}_{3} \cdot 2.38 \mathrm{SiO}_{2} \cdot 1.66 \mathrm{H}_{2} \mathrm{O}\right)$ and the Zeolite-A growth is governed by the Davies-Jones model of growth and dissolution (growth of Zeolite-A from solution coupled with dissolution of the amorphous phase); growth rate decreases with increasing alkalinity 
WSRC-TR-2002-00330, Rev. 0

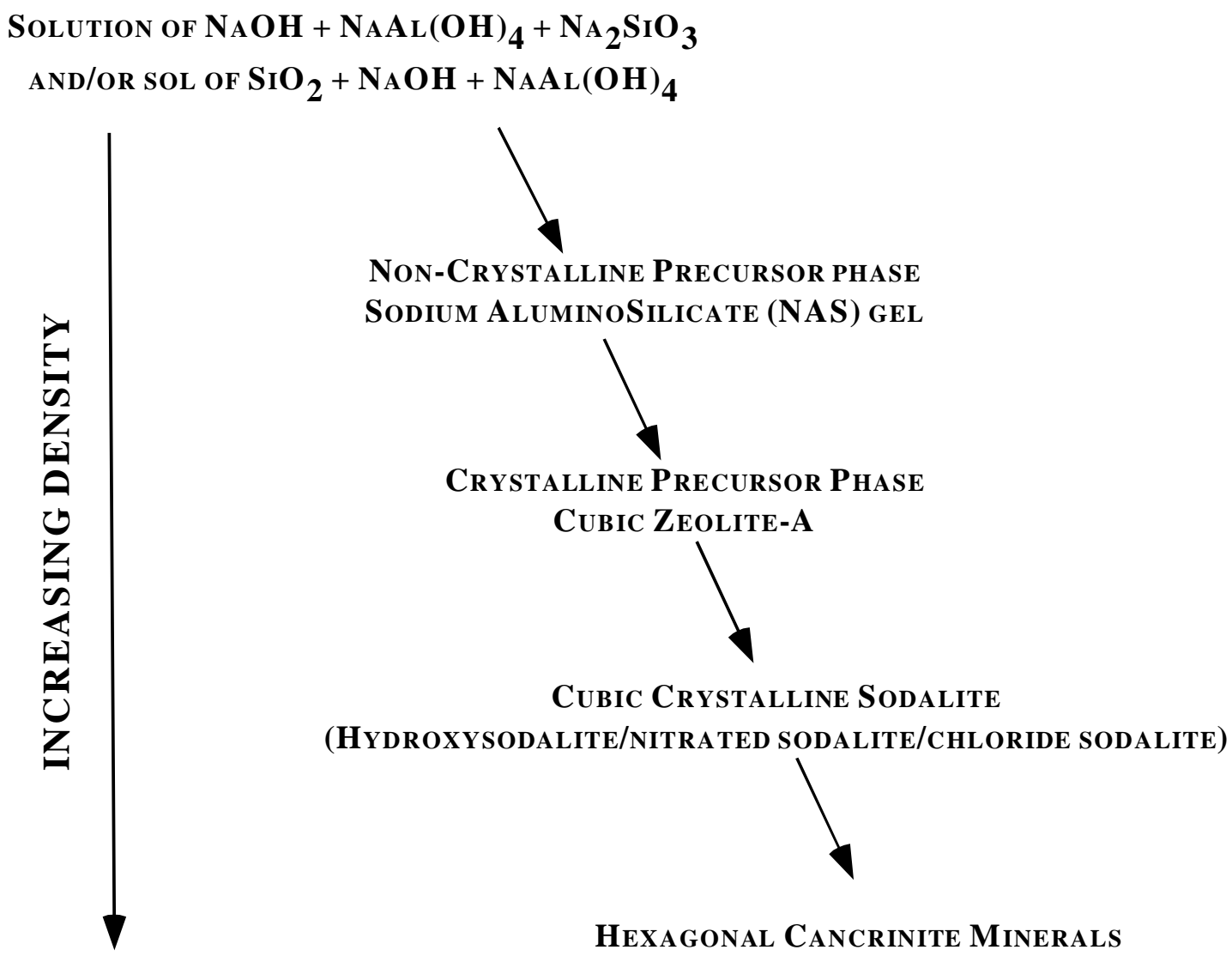

Figure 2. Typical formation and aging (densification) sequence of $\mathrm{NAS}_{\text {gel }} \rightarrow$ Zeolite-A $\rightarrow$ sodalite $\rightarrow$ cancrinite phases depending on the relative concentration of $\mathrm{OH}^{-}, \mathrm{Cl}^{-}$, $\mathrm{NO}_{3}{ }^{-}$, and/or $\mathrm{CO}_{3}{ }^{-}$in the solution in contact with the $\mathrm{NAS}_{\text {gel }}$ (after Gerson, et.al.) ${ }^{20,21}$ 
WSRC-TR-2002-00330, Rev. 0

SOL

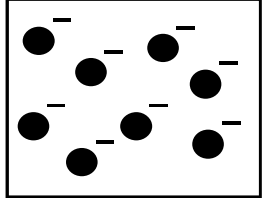

GEL

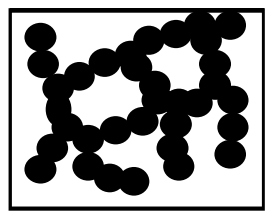

AMORPHOUS

PRECIPITATE

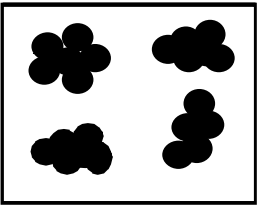

CRYSTALLINE PRECIPITATE

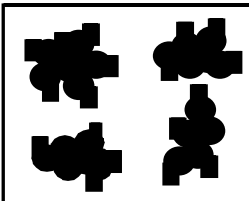

Figure 3. Pictorial diagram showing the differences between a sol, gel, and precipitate (after references 27 and 28). 
As expected due to long aging times, solids isolated from the SRS 2H Evaporator were identified as nitrated sodalite and nitrated cancrinite. In Part $\mathrm{I}^{3}$ of this study the activity diagram modeling indicated that the precursor phase most pertinent to deposition in SRS evaporators was the $\mathrm{NAS}_{\text {gel }}$ due to the short residence times of waste solutions in the evaporators. This was confirmed by kinetic testing performed at $\mathrm{ORNL}^{29}$ and further supported by kinetic testing performed at PNNL. ${ }^{30}$

One set of PNNL kinetic data is plotted as a sequence of overlays showing the activity boundaries for $\mathrm{NAS}_{\mathrm{gel}}$, Zeolite-A, nitrated sodalite and nitrated cancrinite generated using the solubility data of Mensah (Figure 4). This figure demonstrates that when a solution is saturated with respect to $\mathrm{NAS}_{\mathrm{gel}}$ at $80^{\circ} \mathrm{C}$ it first precipitates as the gel, followed by slow dissolution of the gel and formation of Zeolite-A, followed by dissolution of gel and Zeolite-A to form nitrated sodalite as a function of time.

The metastable persistence of an amorphous phase, assumed $f$ to be $\mathrm{NAS}_{\mathrm{gel}}$, and the metastable persistance of sodalite with time complicates using this kinetic data to validate the positions of the phase boundaries based on the Mensah data. ${ }^{8}$ However, in general, the precipitation of Zeolite-A only occurs within its phase field, and the precipitation of cancrinite only occurs within its phase field, confirming that the persistence of the $\mathrm{NAS}_{\mathrm{gel}}$ and sodalite is a metastable phenomenon. More detailed discussion of this data can be found in Part $\mathrm{V}^{9}$ and in the following paragraphs.

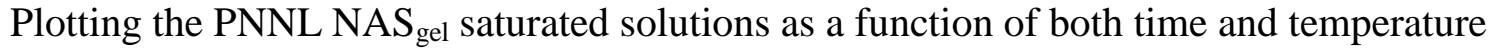
substantiates the presence of the $\mathrm{NAS}_{\text {gel }}$ at elevated temperatures. This graphical representation is known as a time-temperature-transformation (TTT) diagram and is shown in Figure 5. The phase fields represented on the TTT curve obey c-curve kinetics and Hardy's general rule ${ }^{31}$ that the appearance of a more stable decomposition product causes the dissolution of its immediate precursor. The c-shaped curvature of a stable or metastable phase field on a TTT diagram arises from a competition between the driving force for crystallization which increases with decreasing temperature, and the molecular mobility, which decreases with decreasing temperature. ${ }^{32}$ At low temperature, the activation energy for nucleation approaches zero and the low temperature part of the c-curve is approximately linear with a slope of $Q / R$. The numerator, $Q$, is the activation energy of a jump process across an interface and $\mathrm{R}$ is the gas constant. ${ }^{33}$ At low temperatures, the linear portion of the c-curve represents the "retardation temperature" of the nucleation rate and defines a rate curve for a precipitation or reversion reaction ${ }^{34}$ in the absence of nucleating heterogeneities. Hence, the c-curve kinetics define a "nose" in the TTT curve which represents the minimum time required for a given volume fraction to crystallize (precipitate).

The data for all the solutions in Figure 5 indicate that the $\mathrm{NAS}_{\text {gel }}$ persists along with the ZeoliteA and sodalite. With increasing time, the mass percent of the NAS gel $_{\text {decreases as the mass }}$ percent of the crystalline species increases in obeyance of Hardy's law. ${ }^{31}$ The data from solutions \#1 and \#2 in Figure 5 indicate that the phase field of Zeolite-A may persist metastably, e.g. the field of Zeolite-A is truncated by the more stable phase field of NAS gel plus sodalite.

$f \quad$ In the absence of a chemical analysis of the amorphous phase the exact identity of this phase cannot be determined by x-ray diffraction analyses alone, for example it could be amorphous canrinite or amorphous sodalite depending on the anion content and/or on the water of hydrations per unit cell. 
WSRC-TR-2002-00330, Rev. 0

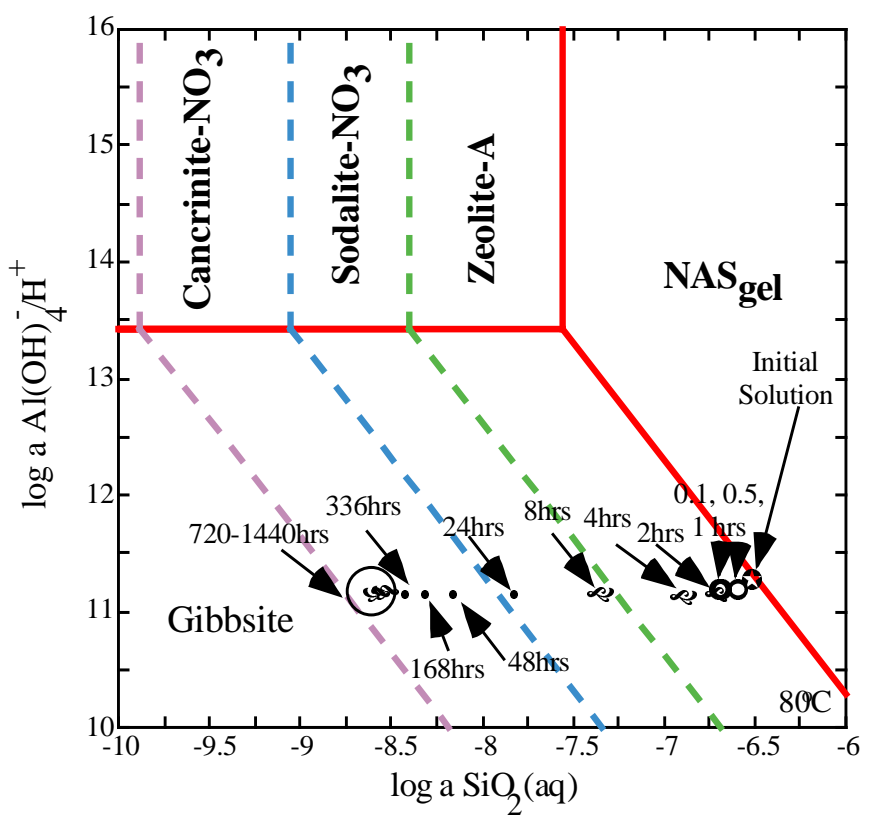

$\mathrm{AS}_{\mathrm{gel}}$

e $\mathbb{N A S}_{\text {gel }}+$ Sodalite + Zeolite-A(tr)

$\leftrightarrow \mathrm{NAS}_{\text {gel }}+$ Sodalite + Cancrinite (tr)

\&NAS gel + Sodalite + Cancrinite (major)

Figure 4. Overlays of the activity diagrams for $\mathrm{NAS}_{\text {gel }}$, Zeolite-A, nitrated sodalite and nitrated cancrinite showing the kinetic data of Mattigod from PNNL. 


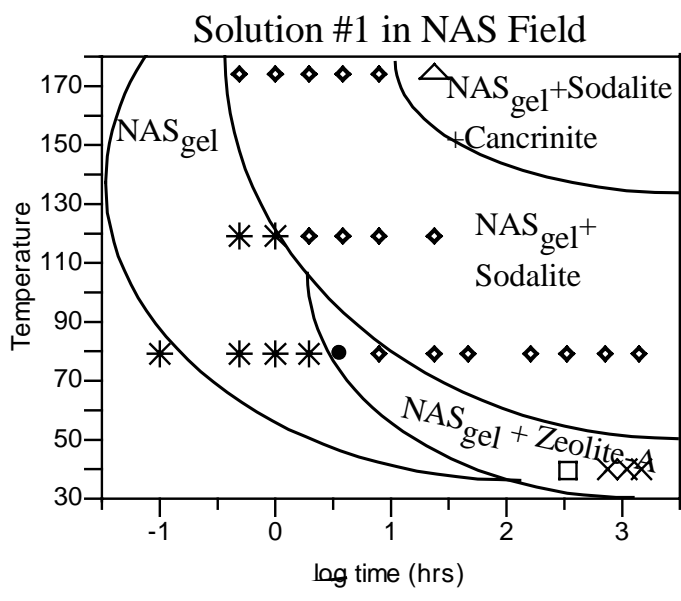

Solution \#3 in NAS Field

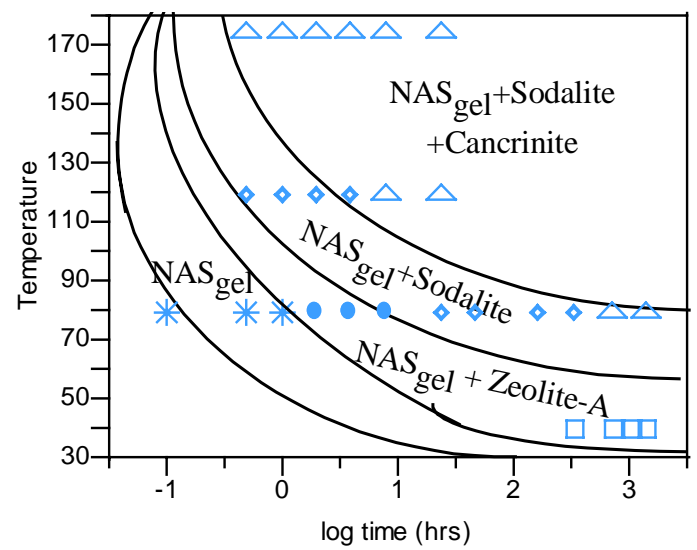

Solution \#2 in NAS Field

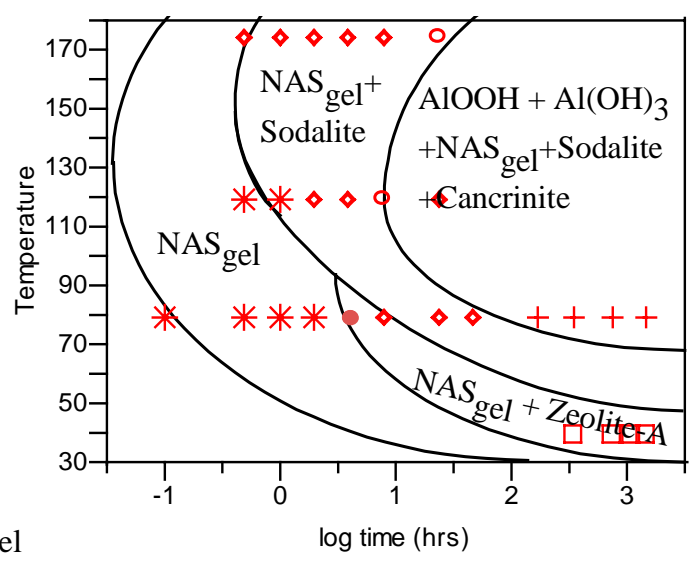

Solution \#4 in NAS Field

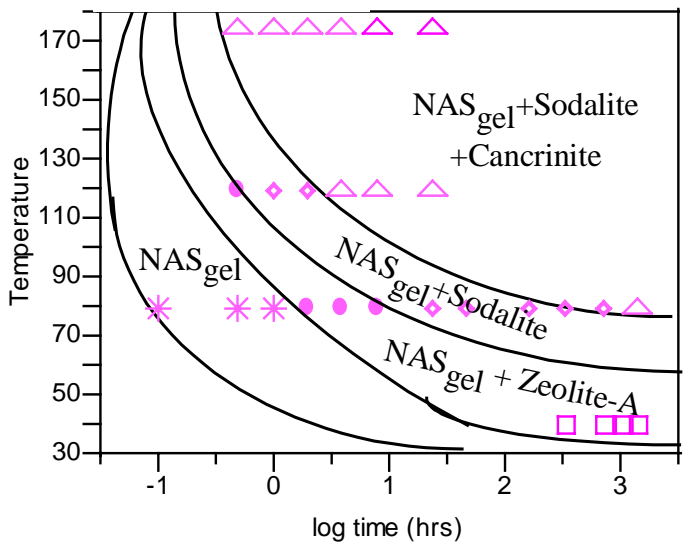

Figure 5. Time-Temperature-Transformation (TTT) diagram of the kinetic data developed by PNNL in support of SRS evaporator modeling. The phase field designations are as follows: $*=\mathrm{NAS}_{\mathrm{gel}} ; \bullet=\mathrm{NAS}_{\mathrm{gel}}+$ Sodalite + Zeolite-A; $\diamond=\mathrm{NAS}_{\mathrm{gel}}+$ Sodalite; $\forall=\mathrm{NAS}_{\text {gel }}+$ Sodalite + Cancrinite; $\cong=\mathrm{NAS}$ gel + Zeolite- $\mathrm{A} ;+=\mathrm{Al}(\mathrm{OH})_{3}$, gibbsite; !=NAS gel $_{\text {boehmite+gibbsite }}$

However, as the $\mathrm{OH}^{-}$concentration is increased (solutions \#3 and \#4) it becomes apparent that the Zeolite-A phase persists up to $120^{\circ} \mathrm{C}$ and may persist at higher temperatures as indicated in Figure 5. The shorter time, higher temperature intervals are under investigation at PNNL.

Based on the kinetic analysis above, it is clear that the $\mathrm{NAS}_{\mathrm{gel}}$ forms first, and that once formed (once a solution is supersaturated with respect to the $\mathrm{NAS}_{\text {gel }}$ ), the $\mathrm{NAS}_{\text {gel }}$ phase can persist at the elevated temperatures in the evaporator along with the more thermodynamically stable sodalite and cancrinite crystalline phases. It is the function of the process control model to prevent the evaporator solutions from ever becoming supersaturated with respect to the $\mathrm{NAS}_{\text {gel }}$; thus preventing the precipitation of the $\mathrm{NAS}_{\text {gel }}$ and all subsequent stable crystalline NAS phases. 
WSRC-TR-2002-00330, Rev. 0

\subsection{RECENT ANALYTIC DATA AVAILABLE FOR EVAPORATOR MODELING}

\subsection{Availability of Analytic Data}

A compilation of molar chemical analyses for Tanks 30, 32, 26, 46, 43, and 38 that were used in the modeling and validation in this study appears in Table I, Table II, and Table III for the time period January 1995 to June 2002. All of this data was analyzed at SRTC where the silicon analyses represent the entire sample instead of one aliquot (one pipette volume). While there is historic data from 1992 available from SRTC, the silicon analyses associated with these historic samples were only measured from one pipette volume, which is inadequate when inhomogeneously dispered colloidal silica is present. There were sparse and incomplete data for many minor cations and anions. When data for these minor cation species (e.g. Fe and K) were missing or below the analytical detection limit, $1 / 2$ the instrument detection limit was substituted assuming that a small concentration below the detection limits was probably present. The latter accounts for errors of 100-200\% for a concentration at or near the instrument detection limit.

Sodium analyses, when available, were added into Table I, Table II, and Table III using data from various SRTC reports by Wilmarth (documented in the tables). ${ }^{35,}{ }^{36}$ Conversely, Wilmarth did not analyze for the cation $\mathrm{K}^{+}$nor several anions, e.g. $\mathrm{Cl}, \mathrm{CO}_{3}{ }^{2-}, \mathrm{F}^{-}, \mathrm{PO}_{4}{ }^{3-}, \mathrm{SO}_{4}{ }^{2-}$. When minor anion species such as these were missing or below the analytical detection limit, $1 / 2$ the instrument detection limit was substituted. Occasionally, data from F-Area laboratory was substituted from samples taken on the same day as the SRTC samples or averaged from F-Area laboratory analyses that bracketed the missing data, e.g. usually taken 3 months before and 3 months after the missing data.

All available tank data modeled were measured at ambient $\left(\sim 25^{\circ} \mathrm{C}\right)$ laboratory conditions and not at the tank temperature at the time of sampling. Bulk supernate temperatures can vary from $30^{\circ} \mathrm{C}$ to $75^{\circ} \mathrm{C}$. Possible changes in solution composition upon cooling of the tank samples were not accounted for during the measurements. However, temperature affects are accounted for during modeling at elevated temperatures with GWB.

\subsection{Consistency of Analytic Data}

In order to use the chemical analyses compiled in Table I, Table II, and Table III for modeling, the data had to be made internally consistent, e.g., anion and cation charges were balanced. Since few measured $\mathrm{Na}^{+}$molarities were available no adjustments were made to the molarities of the three principal anions, $\mathrm{OH}^{-}, \mathrm{NO}_{3}{ }^{-}$, and $\mathrm{NO}_{2}{ }^{-}$to balance against measured $\mathrm{Na}^{+}$concentrations. The charge balance calculations assumed a single ionic species; most importantly, Al was modeled as $\mathrm{Al}(\mathrm{OH})_{4}^{-}$and $\mathrm{Si}$ as $\mathrm{H}_{2} \mathrm{SiO}_{4}{ }^{2-}$.

The GWB software uses molality instead of molarity when performing the basic thermodynamic calculations. If molarity is entered instead of molality, GWB uses a default density of $1 \mathrm{gm} / \mathrm{cm}^{3}$ or the user has to specify both a density and total dissolved solids (TDS). Rather than specify a solution density and TDS, the molar concentration data in Table I, Table II, and were converted 
WSRC-TR-2002-00330, Rev. 0

to molalities (see Section 4.0). The molalities are based on calculated solution densities and total weight of the solutes (Equation 2). ${ }^{37}$ The solution densities were calculated from a calculated $\mathrm{Na}^{+}$ molarity, $\left\lfloor\mathrm{Na}^{+}\right\rfloor_{\text {calc }}$, using Equation 3 derived in Appendix A from over 1800 supernate samples taken over a period of 29 years (1973-2001) and measured at ambient laboratory conditions.

$$
\text { Equation } 2 \quad m=M\left(\frac{\text { weight solution }}{(\text { weight solution }- \text { total weight } \text { solutes })_{\text {ensity }} \text { calc }}\right)
$$

where $\mathrm{m}=$ molality

$$
\mathrm{M}=\text { molarity }
$$

$$
\begin{aligned}
& \text { weight solutes }=\frac{\text { dissolved solids }(\mathrm{g} / \mathrm{L})}{1000 \mathrm{~L}} \\
& \qquad \begin{aligned}
\mathrm{Al}(\mathrm{OH})_{4}^{-}+\mathrm{Cl}^{-}+\mathrm{CO}_{3}^{-2}+\mathrm{C}_{2} \mathrm{O}_{4}^{-2}+\mathrm{F}^{-}+\mathrm{NO}_{2}^{-}+\mathrm{NO}_{3}^{-} \\
\text {dissolved solids }= \\
+\mathrm{OH}^{-}+\mathrm{PO}_{4}^{-3}+\mathrm{SO}_{4}^{-2}+\mathrm{Fe}(\mathrm{OH})_{4}^{-}+\mathrm{K}^{+}+\mathrm{H}_{2} \mathrm{SiO}_{4}^{-2}+ \\
\mathrm{UO}_{2}(\mathrm{OH})_{\frac{7}{3}}+\left[\mathrm{Na}_{\text {calc }}^{+}\right]
\end{aligned}
\end{aligned}
$$

Equation 3 density $_{\text {calc }} \equiv \rho=1.0133+0.05701\left[\mathrm{Na}^{+}\right]_{\text {calc }}-0.001725\left[\mathrm{Na}^{+}\right]_{\text {calc }}^{2}$

where $\rho$ is the calculated solution density (see Appeindix B) in $\mathrm{g} / \mathrm{cm}^{3}$ and $\left[\mathrm{Na}^{+}\right\rfloor_{\text {calc }}$ is the calculated molar $\mathrm{Na}^{+}$concentration from Equation 4.

$$
\mathrm{NaAl}(\mathrm{OH})_{4}+\mathrm{NaCl}+\mathrm{Na}_{2} \mathrm{CO}_{3}+\mathrm{Na}_{2} \mathrm{C}_{2} \mathrm{O}_{4}+\mathrm{NaF}+
$$

Equation $4 \quad \mathrm{Na}_{\text {calc }}^{+}=\mathrm{NaNO}_{2}+\mathrm{NaNO}_{3}+\mathrm{NaOH}+\mathrm{Na}_{3} \mathrm{PO}_{4}+\mathrm{Na}_{2} \mathrm{SO}_{4}+\mathrm{NaFe}(\mathrm{OH})_{4}^{-}$

$$
-\mathrm{KOH}+\mathrm{Na}_{2} \mathrm{H}_{2} \mathrm{SiO}_{4}+\mathrm{Na}\left(\mathrm{UO}_{2}\right)_{3}(\mathrm{OH})_{7}
$$

The molal contributions from $\mathrm{CO}_{3}{ }^{-2}$ and $\mathrm{C}_{2} \mathrm{O}_{4}{ }^{-2}$ were summed as a total $\mathrm{CO}_{3}{ }^{-2}$ contribution, e.g. one mole of $\mathrm{C}_{2} \mathrm{O}_{4}{ }^{-2}$ was considered to be two moles of $\mathrm{CO}_{3}{ }^{-2}$ since Geochemist's Workbench can only accommodate one carbon species at a time. The $\mathrm{NO}_{2}{ }^{-}$and $\mathrm{NO}_{3}{ }^{-}$were summed as $\mathrm{NO}_{3}{ }^{-}$ since Geochemist's Workbench can only accommodate one nitrogen species at a time.

In addition to reporting molar concentrations, Table I, Table II, and Table III compare calculated and measured solution densities. Solution densities were calculated from Equation 3. The majority $(>75 \%)$ of the measured and calculated densities agreed within $5 \%$. 
WSRC-TR-2002-00330, Rev. 0

\subsection{Quality of Analytic Data}

The SRTC and the F-area laboratories both analyzed samples taken between February 2001 and July 2002. The two laboratories never measured the same sample taken on the same day so no comparisons of the analytic bias between the two laboratories can be made for this set of data. However, in Parts $\mathrm{I}^{3}$ and Part $\mathrm{II}^{4}$ of this study it was shown that the $210 \mathrm{X}$ dilution performed by the F-area laboratory always caused their $\mathrm{Si}$ analyses to be biased high compared to those of SRTC. The lower the actual Si concentration $\left(\right.$ Part $\left.\mathrm{II}^{4}\right)$ the higher the bias (compare to Part $\left.\mathrm{I}^{3}\right)$. In addition, samples taken during the receipt of high Al-containing canyon waste in the $2 \mathrm{H}$ Evaporator were analyzed $^{3}$ as being at the detection limit for $\mathrm{Al}$ which is impossible.

SRTC has developed a method by which the entire sample $(70 \mathrm{~mL})$ is filtered so that the total amount of Si (both soluble and colloidal) can be more accurately determined. The filtrate, representing the soluble silicon, is homogeneous and can be accurately measured by ICP. The colloidal silicon on the filter is dissolved and measured separately. The two are added together for a final total silicon analysis that is representative of the entire sample ${ }^{35,36}$ rather than a few milliliters of solution in a pipette. Because of the high bias in the F-area laboratory Si analyses, only the Si analyses reported by Wilmarth were used for modeling in Part $\mathrm{I}^{3}$ and $\mathrm{Part}_{\mathrm{II}}^{4}$ of this study. This is the method used to determine the silica for all samples used in modeling in Table I, Table II, and Table III. Recently, a warm acid strike treatment for silicon analyses of evaporator solutions has been developed ${ }^{38}$ which was determined to be as accurate as the filtration method described above. 



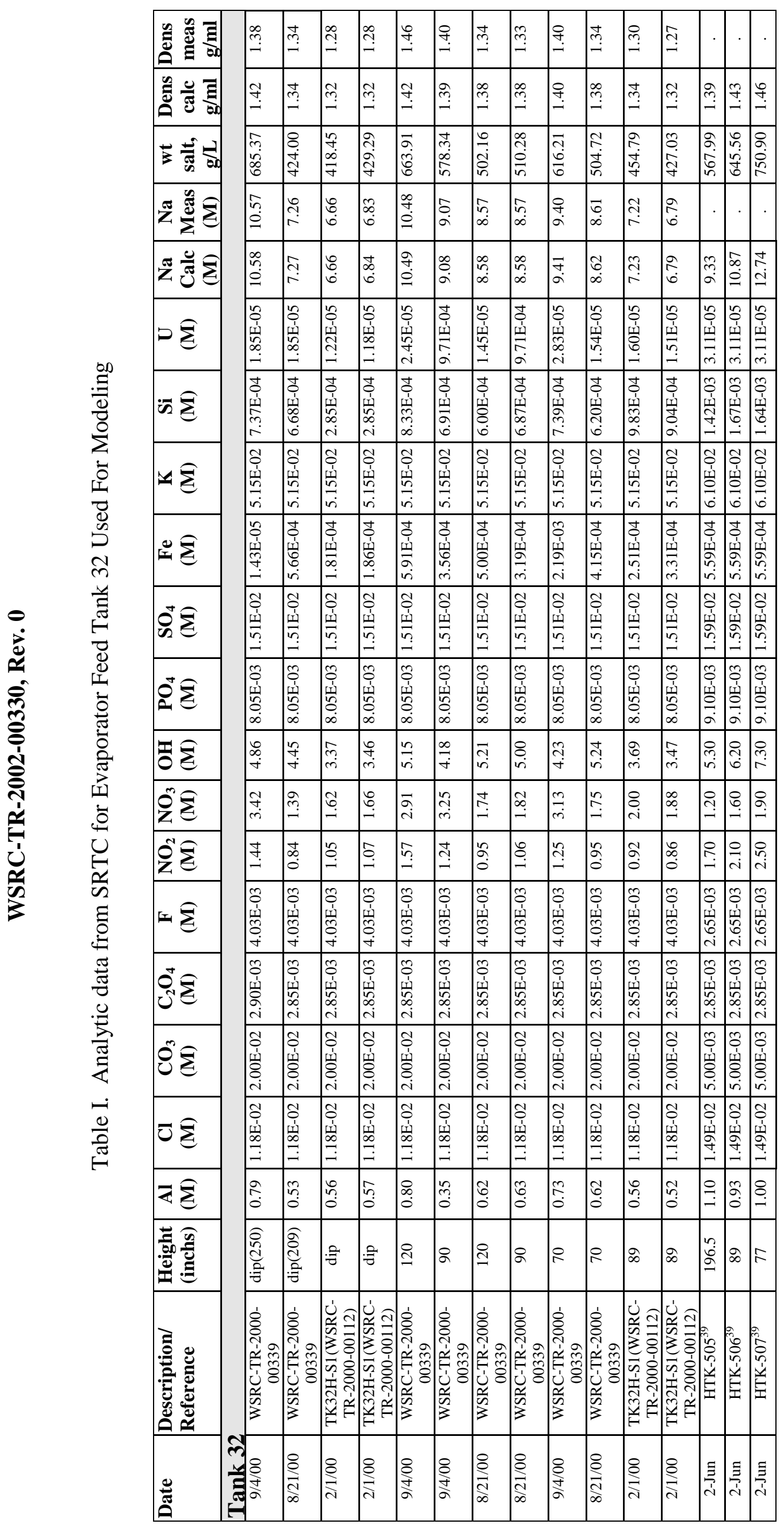




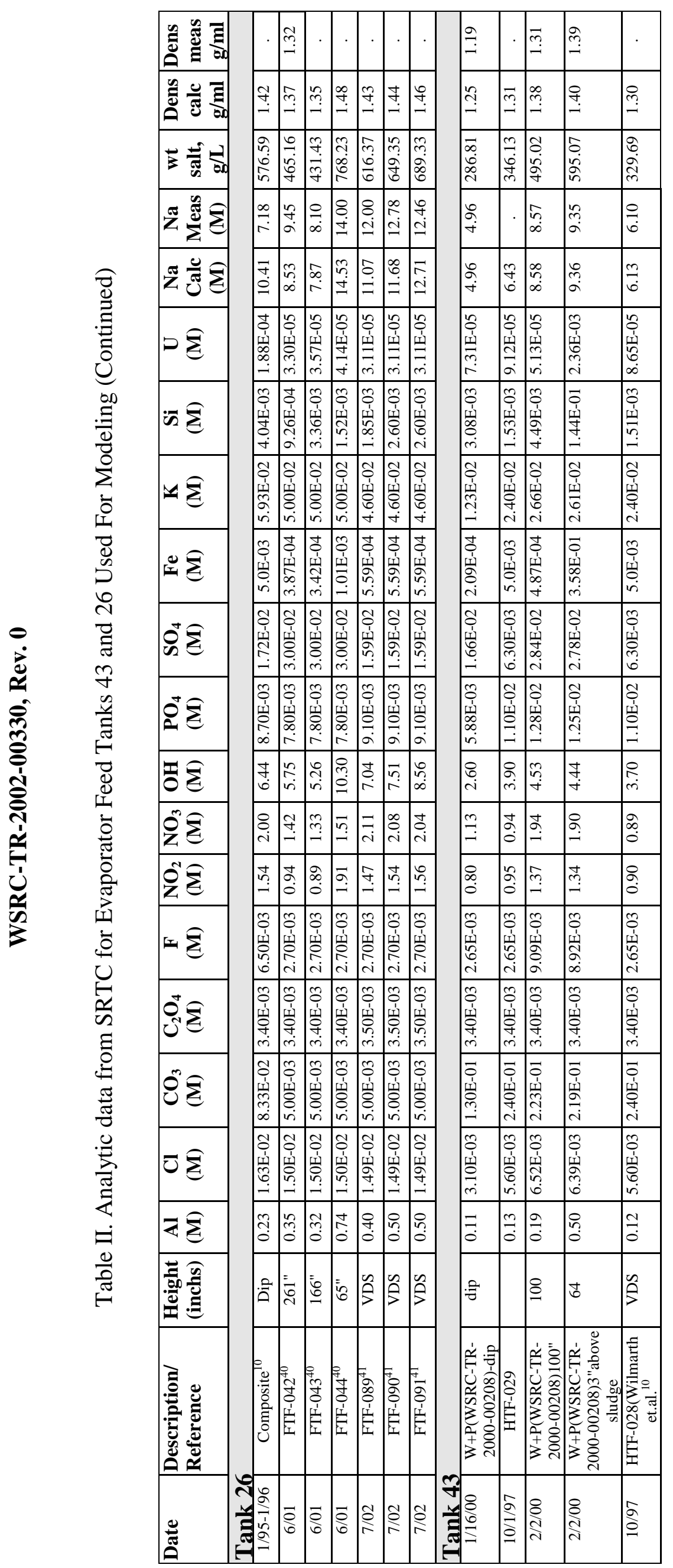




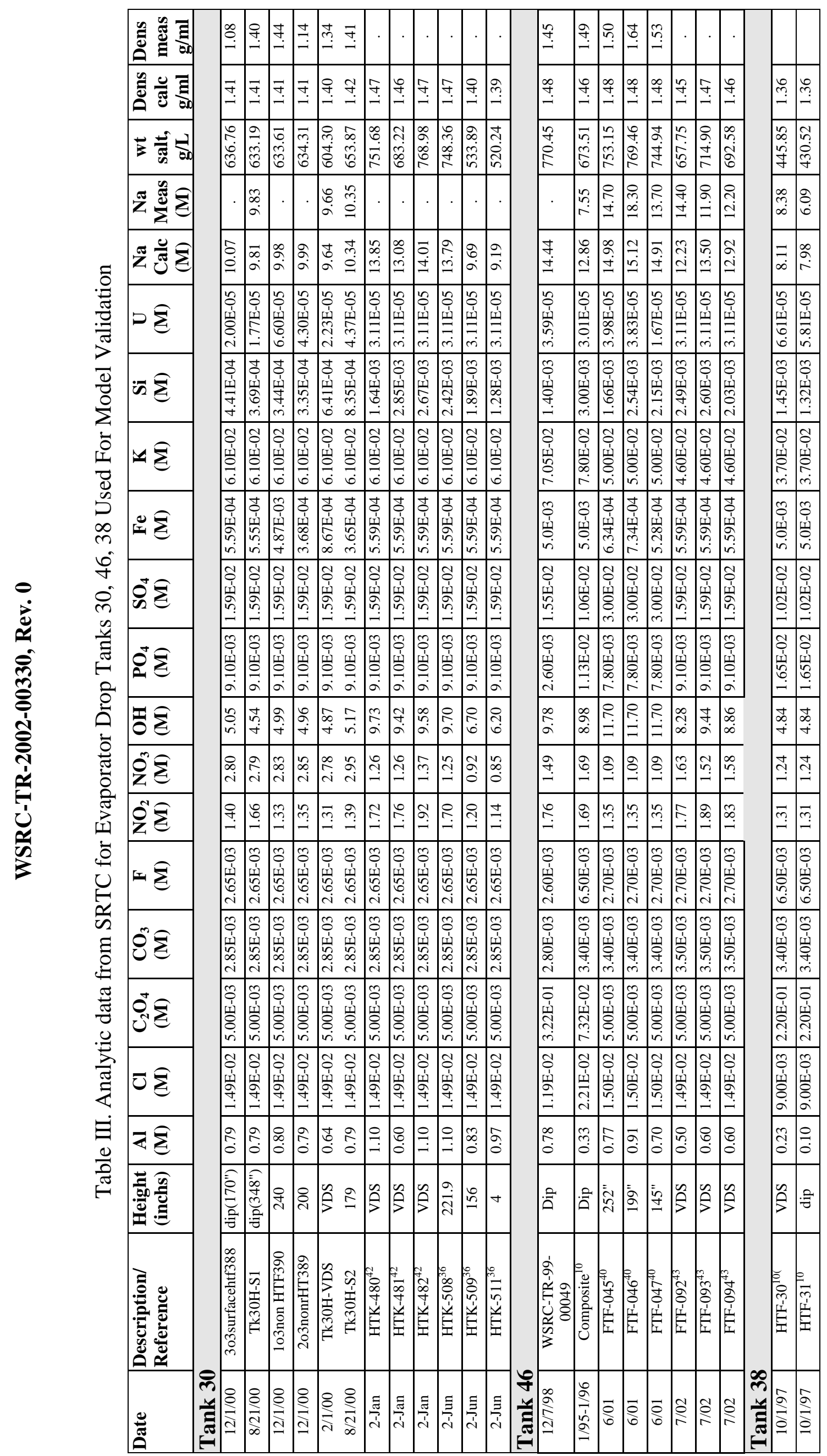




\subsection{MODELING APPROACH}

The molar tank compositions given in Table I, Table II, and Table III were converted into molal units which are the units of preference in the GWB software. The conversion formula takes the form $^{5}$

$$
\left[\mathrm{i}^{+/-}\right]_{\mathrm{m}}=\frac{\left[\mathrm{i}^{+/-}\right]_{\mathrm{M}}}{\rho-\sum \rho_{\text {solutes }}}
$$

where $\left[\mathrm{i}^{+/-}\right]_{\mathrm{M}}$ and $\left[\mathrm{i}^{+/-}\right\rfloor_{\mathrm{m}}$ are the molar and molal concentrations of ionic species $\mathrm{i}$, respectively, $\rho$ is the solution density in $\mathrm{kg} / \mathrm{L}$, and $\Sigma \rho_{\text {solutes }}$ is the sum of the partial densities of the dissolved solids. The solution density is calculated using Equation 3. For each ionic species, the partial dissolved solids density is the product of its molarity and its ionic weight in $\mathrm{g} / \mathrm{mole}$. Ionic weights for the most prevalent species in basic solutions such as the SRS evaporators are used. These are $\mathrm{Al}(\mathrm{OH})_{4}^{-}, \mathrm{Cl}^{-}, \mathrm{CO}_{3}{ }^{2-}, \mathrm{F}^{-}, \mathrm{NO}_{2}{ }^{-}, \mathrm{NO}_{3}{ }^{-}, \mathrm{OH}^{-}, \mathrm{PO}_{4}{ }^{3-}, \mathrm{SO}_{4}{ }^{2-}, \mathrm{Fe}(\mathrm{OH})_{4}{ }^{-}, \mathrm{K}^{+}, \mathrm{H}_{2} \mathrm{SiO}_{4}{ }^{2-}$, $\left(\mathrm{UO}_{2}\right)_{3}(\mathrm{OH})_{7}^{-}$, and $\mathrm{Na}^{+}$.

There is limited solubility data for amorphous $\mathrm{SiO}_{2}$ and $\mathrm{Al}(\mathrm{OH})_{3}$ in very basic, high ionic strength solutions such as those in the SRS evaporators. This is discussed in more detail in Part I. ${ }^{3}$ Comparison with available $\mathrm{SiO}_{2}$ solubility data in the literature showed that the solubility data used in GWB appeared to adequately represent amorphous $\mathrm{SiO}_{2}$ equilibrium in basic solutions. GWB has the mononuclear silicate species $\mathrm{H}_{4} \mathrm{SiO}_{4}$ called $\mathrm{SiO}_{2}(\mathrm{aq}), \mathrm{H}_{3} \mathrm{SiO}_{4}{ }^{-}$and $\mathrm{H}_{2} \mathrm{SiO}_{4}{ }^{2-}$ of which the $\mathrm{H}_{2} \mathrm{SiO}_{4}{ }^{2-}$ species is the most prevalent at $\mathrm{pH}$ values $>13 .{ }^{44} \mathrm{GWB}$ also contains the two most abundant ${ }^{45,44}$ polynuclear silicate species, the tetrameric $\mathrm{H}_{4}\left(\mathrm{H}_{2} \mathrm{SiO}_{4}\right)_{4}{ }^{4-}$ and $\mathrm{H}_{6}\left(\mathrm{H}_{2} \mathrm{SiO}_{4}\right)_{4}{ }^{2-}$ of which the tetrameric $\mathrm{H}_{4}\left(\mathrm{H}_{2} \mathrm{SiO}_{4}\right)_{4}{ }^{4-}$ is the most prevalent species at $\mathrm{pH}$ values $>13 .{ }^{44}$ Polynuclear $\mathrm{Si}(\mathrm{IV})$ species are only significant at $\mathrm{pH}>10$ and at total dissolved $\mathrm{Si}$ concentrations larger than $10^{-3} \mathrm{M}^{46}$ In addition, the significance of the polynuclear $\mathrm{Si}(\mathrm{IV})$ species tends to decrease with increasing temperature. ${ }^{47}$ Since the SRS Evaporator Si concentrations are in the $10^{-4} \mathrm{M}$ range (Table I, Table II, and Table III) and the polynuclear Si(IV) species are of minimal importance at the elevated evaporator operating temperatures $\left(>120^{\circ} \mathrm{C}\right)$, the absence of the remaining polynuclear $\mathrm{Si}(\mathrm{IV})$ species in the GWB database is not considered to significantly impact the modeling.

Examination of the gibbsite solubility data in GWB with that in the literature indicated that Russell's ${ }^{48}$ solubility data at a sodium molality of 8.5 would be more appropriate for modeling at the high ionic strength of the SRS Evaporators. The Russel solubility data for gibbsite (alpha aluminum trihydrate) ${ }^{f}$ and diaspore (alpha aluminum monohydrate) ${ }^{\phi}$ were added to GWB database and designated as "gibbsite-M" and "diaspore-M" to distinguish these modified aluminum hydroxides from the gibbsite and diaspore solubility already in GWB. The Russel gibbsite-M and diaspore-M were used for modeling the SRS 3H Evaporator solutions. The data for the solubility of $\mathrm{NaAlO}_{2}$ and $\mathrm{AlO}_{2}{ }^{-2}$ of Reynolds and Herting ${ }^{49}$ were also added to GWB for

\footnotetext{
$f$ bayerite is the gamma aluminum trihydrate

$\phi$ boehmite is the gamma aluminum monohydrate
} 
WSRC-TR-2002-00330, Rev. 0

completeness. Detailed descriptions of the manner in which the data were added to the GWB database appear in Part I. ${ }^{3}$

The SRS solubility specific data of Mensah et $\mathrm{al}^{8}$ were added to the database for the NAS ${ }_{\text {gel }}$, Zeolite-A, nitrated sodalite, and nitrated cancrinite. The manner in which the aluminosilicate

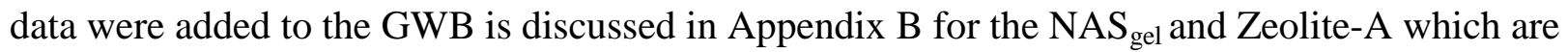
discussed in this study. The database modifications for the nitrated aluminosilicates are discussed in Part V. ${ }^{9}$

\subsection{PROCESS MODELING FOR NOMINAL EVAPORATOR OPERATION}

The new solubility data for $\mathrm{NAS}_{\text {gel }}$ precipitation developed by Mensah et al ${ }^{8}$ of the University of Southern Australia (USA) have been incorporated into a revised thermodynamic model for the SRS evaporators. A nominal evaporation model is developed with a pooled operating temperature data set $\left(120^{\circ} \mathrm{C}\right.$ for the $2 \mathrm{H}$ and $2 \mathrm{~F}$ Evaporators and $140^{\circ} \mathrm{C}$ for the $3 \mathrm{H}$ Evaporator) in order to understand the importance of temperature on the model. The nominal process model is examined at a nominal 40\% evaporation. The nominal evaporation model is based on 27 feed tank data points analyzed at SRTC including data from 1995 to 2002 from all three SRS evaporators (Tables in Part I, ${ }^{3}$ Part II, ${ }^{4}$ and this study). In Sections 5.2 and 5.3 it is shown that the model is relatively insensitive to evaporator operating temperature but more dependent on the percent evaporation. In Section 6.1 the model is validated with an orthogonal latin hypercube $(\mathrm{OLH})$ design in the $120-140^{\circ} \mathrm{C}$ range at the nominal evaporation of $40 \%$ and in Section 6.2 with drop tank data. This demonstrates that tank chemistry can be simulated using the OLH approach when the solution concentration distributions (Gaussian or lognormal) and chemical ranges are matched.

In Section 7.0 a final evaporator model is developed over a wider composition region to accommodate future evaporator liquors to be processed. A temperature term and percent evaporation or evaporator solution density is added to the final process model as well. The final model is based on 200 simulated evaporator solutions calculated over the wider composition region, broader temperature and percent evaporation intervals via an orthogonal latin hypercube $(\mathrm{OLH})$ design.

The stoichiometry of the reaction that forms the $\mathrm{NAS}_{\text {gel }}$ from solution or from silica sols governs the process control model, e.g. the abcissa. The amorphous aluminosilicate gel precursor of Ejaz $^{6}$ was the stoichiometry used in the first SRS evaporator process model

$\left(0.93 \mathrm{Na}_{2} \mathrm{O}: 1 \mathrm{Al}_{2} \mathrm{O}_{3}: 2.32 \mathrm{SiO}_{2}: 5.15 \mathrm{H}_{2} \mathrm{O}\right)$ which is $\mathrm{Na}_{12} \mathrm{Al}_{12} \mathrm{Si}_{14} \mathrm{O}_{52} \bullet 31 \mathrm{H}_{2} \mathrm{O}$ stoichiometry. It is very similar to that reported by Bosnar and Subotic ${ }^{26}$ but not identical (see Section 2.4). Mensah et. al. ${ }^{8}$ chemically analyzed the $\mathrm{NAS}_{\text {gel }}$ and it was this gel that was subsequently used for solubility testing in SRS simulated evaporator solutions up to $12 \mathrm{M} \mathrm{NaOH}$. His composition, is $0.996 \mathrm{Na}_{2} \mathrm{O}: \mathrm{Al}_{2} \mathrm{O}_{3}: 1.994 \mathrm{SiO}_{2}: 4.5 \mathrm{H}_{2} \mathrm{O}$ which in this study is rounded to $\mathrm{Na}_{2} \mathrm{O}: \mathrm{Al}_{2} \mathrm{O}_{3}: 2 \mathrm{SiO}_{2}: 4.5 \mathrm{H}_{2} \mathrm{O}$ or $\mathrm{Na}_{12} \mathrm{Al}_{12} \mathrm{Si}_{12} \mathrm{O}_{48} \bullet 27 \mathrm{H}_{2} \mathrm{O}$.

Geochemist's Workbench assumes that the $\mathrm{NAS}_{\text {gel }}$ is formed from solution species, since the database does not have any solubility data for a silica sol. The equations that represent the saturation of the solution with respect to the $\mathrm{NAS}_{\text {gel }}$ are defined by the steady state equilibrium 


\section{WSRC-TR-2002-00330, Rev. 0}

boundary on the activity diagrams which separates the field of $\mathrm{AlOOH}$ (diaspore) from the field

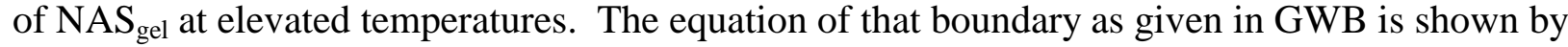
Equation 5.

Equation $5 \quad 6$ Diaspore $+15 \mathrm{H}_{2} \mathrm{O}+6 \frac{\mathrm{Al}(\mathrm{OH})_{4}^{-}}{\mathrm{H}^{+}}+12 \mathrm{SiO}_{2}(\mathrm{aq})+12 \mathrm{Na}^{+} \Leftrightarrow \mathrm{NAS}_{\mathrm{gel}}$

Equation 5 can be rewritten as

Equation 6

$$
6 \mathrm{AlOOH}+15 \mathrm{H}_{2} \mathrm{O}+6 \mathrm{Al}(\mathrm{OH})_{4}^{-}+12 \mathrm{SiO}_{2}(\mathrm{aq})+12 \mathrm{Na}^{+} \Leftrightarrow \mathrm{Na}_{12} \mathrm{Al}_{12} \mathrm{Si}_{12} \mathrm{O}_{48} \bullet 27 \mathrm{H}_{2} \mathrm{O}+6 \mathrm{H}^{+}
$$

where the $\mathrm{NAS}_{\text {gel }}$ formula $\mathrm{Na}_{12} \mathrm{Al}_{12} \mathrm{Si}_{12} \mathrm{O}_{48} \bullet 27 \mathrm{H}_{2} \mathrm{O}$ is the chemical composition from Mensah et. al. ${ }^{8}$ as given in Section 2.4 above.

Use of Equation 6 for the development of the process control algorithm would have resulted in relying on a measurement of the $\mathrm{pH}$ which is inherently inaccurate at $\mathrm{pH}$ values of $>13,{ }^{7,50}$ the $\mathrm{pH}$ values reported for the SRS evaporator feeds. Since free hydroxide is routinely measured for the SRS evaporators and it is a more accurate measurement than the $\mathrm{pH}$ this term was substituted in Equation 6. Likewise, the $\mathrm{Na}^{+}$should be expressed as $\mathrm{NaOH}$ consistent with Equation 1 and the work of Mattigod and McGrail. ${ }^{51}$ Since the kinetics of the formation of AlOOH is slow, on the order of hours to days, all the aluminum species can be represented as $\mathrm{Al}(\mathrm{OH})_{4}^{-}$and Equation 6 rewritten in terms of the hydroxide species as shown in Equation 7:

Equation $712 \mathrm{Al}(\mathrm{OH})_{4}^{-}+12 \mathrm{SiO} 2(\mathrm{aq})+12 \mathrm{NaOH}+3 \mathrm{H}_{2} \mathrm{O} \Leftrightarrow \mathrm{Na}_{12} \mathrm{Al}_{12} \mathrm{Si}_{12} \mathrm{O}_{48} \bullet 27 \mathrm{H}_{2} \mathrm{O}+12 \mathrm{OH}^{-}$

There is a high statistical co-linearity between $\log \mathrm{Na}(\mathrm{M})_{\text {calc }}$ and $\log \mathrm{OH}(\mathrm{M})$ in the SRS evaporator solutions modeled in this study since $\log \mathrm{OH}(\mathrm{M})$ is the major component in the equation defining $\mathrm{Na}(\mathrm{M})_{\text {calc }}$ (see Equation 4 where $\mathrm{OH}(\mathrm{M})$ is expressed as $\mathrm{NaOH}$ ). This is not surprising since the main component of the evaporator solutions is $\mathrm{NaOH}$.

Because of the co-linearity of $\log \mathrm{Na}(\mathrm{M})_{\text {calc }}$ and $\log \mathrm{OH}(\mathrm{M})$, Equation 7 is rewritten subtracting out the $\mathrm{NaOH}$ term:

Equation $8 \quad 12 \mathrm{Al}(\mathrm{OH})_{4}^{-}+12 \mathrm{SiO}_{2}(\mathrm{aq})+3 \mathrm{H}_{2} \mathrm{O} \Leftrightarrow \mathrm{Al}_{12} \mathrm{Si}_{12} \mathrm{O}_{42} \bullet 21 \mathrm{H}_{2} \mathrm{O}+12 \mathrm{OH}^{-}$

The $\mathrm{K}_{\mathrm{sp}}$ for this reaction is 
Equation $9 \quad K_{s p}\left(\mathrm{NAS}_{g e l}\right)=\frac{\left[\mathrm{NAS}_{g e l}\right]\left[\mathrm{OH}^{-}\right]^{12}}{\left[\mathrm{Al}(\mathrm{OH})_{4}^{-}\right]^{12}\left[\mathrm{SiO}_{2}(a q)\right]^{12}\left[\mathrm{H}_{2} \mathrm{O}\right]^{3}}$

Equation 9 can be further simplified since the $\mathrm{NAS}_{\mathrm{gel}}$ and the water are in their standard states and equal to 1 as shown in Equation 10

Equation $10 \quad K_{s p}\left(\mathrm{NAS}_{g e l}\right)=\frac{\left[\mathrm{OH}^{-}\right]^{12}}{\left[\mathrm{Al}(\mathrm{OH})_{4}^{-}\right]^{12}\left[\mathrm{SiO}_{2}(a q)\right]^{12}}$

or in logarithmic form

Equation $11 \log K_{s p}\left(\mathrm{NAS}_{g e l}\right)=12 \log \left[\mathrm{OH}^{-}\right]-12 \log \left[\mathrm{Al}(\mathrm{OH})_{4}{ }^{-}\right]-12 \log \left[\mathrm{SiO}_{2}(\mathrm{aq})\right]$

Rewriting Equation 11 in terms of the species measured in the SRS Evaporator feed tanks, e.g. $\mathrm{Al}(\mathrm{M}), \mathrm{Si}(\mathrm{M}), \mathrm{OH}(\mathrm{M})$, multiplying both sides by -1 , gives the following equation:

Equation $12-\log Q\left(N A S_{g e l}\right)_{25^{\circ} \mathrm{C}}=12 \log [A l(M)]+12 \log [\operatorname{Si}(M)]-12 \log [O H(M)]$

Equation 12 represents the formation of the aluminosilicate "cage" structure of the NAS $S_{\text {gel }}$. Basing the SRS evaporator process control model on Equation 12 allowed an ordinary least squares (OLS) correlation of the measured ambient feed tank concentrations to their potential to saturate in the evaporator pot after a $40 \mathrm{wt} \%$ nominal evaporation (Figure 6). This nominal model is based only on three compositional parameters that are routinely measured in the tank farm, e.g. $\log [\mathrm{Al}(\mathrm{M})], \log [\mathrm{Si}(\mathrm{M})])$, and $\log [\mathrm{OH}(\mathrm{M})]$ at a nominal evaporation of $40 \%$ and an operating temperature interval of $120-140^{\circ} \mathrm{C}$. The OLS correlation between evaporator pot saturation and ambient feed tank chemisty is given in Equation 13 and defined as the nominal SRS evaporator model derived from the SRS specific solubility data. ${ }^{8}$

Equation $13 \log (Q / K)_{N A S 120-140^{\circ} \mathrm{C} / 40 \% \text { evap }}=\begin{aligned} & 37.4848+1.0949(12 \log [A l(M)]+12 \log [\operatorname{Si}(M)] \\ & -12 \log [O H(M)])\end{aligned}$

where the tank chemistry is expressed on the RHS of Equation 13, hereafter referred to as $\log \mathrm{Q}$ $(\mathrm{NAS})_{25^{\circ} \mathrm{C}}$, and the supersaturation index of the feed in the evaporator pot is expressed on the LHS, hereafter referred to as $\log (\mathrm{Q} / \mathrm{K})_{\text {NAS }}$. Note that the temperature affects on the solution concentrations are taken into account by GWB during the calculation of the LHS of the equation. The $\mathrm{R}^{2}$ of the OLS correlation given Equation 13 is 0.93 based on variable depth data analyzed only by SRTC for the evaporator feed tanks, a total of 27 data points (Figure 6). The intercept includes the evaporation term, the numeric conversions from molar to molal concentrations, corrections for the activity coefficients, and temperature corrections for the solubility of the solid species, diaspore and $\mathrm{NAS}_{\text {gel. }}$. The stoichiometry of the x-axis is defined by the stoichiometry of the $\mathrm{NAS}_{\text {gel }}$ and cannot be applied to phases with other stoichiometry. 


\subsection{Comparison of Evaporator Models Based on Mensah vs. Ejaz}

The SRS evaporator model generated based on the data of Ejaz (Parts I, ${ }^{3} \mathrm{II}^{4}$ and $\mathrm{III}^{5}$ of this study) versus the model developed based on the SRS evaporator specific solubility data ${ }^{8}$ is shown in Figure 7. The $\mathrm{NAS}_{\text {gel }}$ measured by Mensah et $\mathrm{al}^{8}$ is more soluble than the $\mathrm{NAS}_{\mathrm{gel}}$ measured by Ejaz ${ }^{6}$ and the solubility is a strong function of $\mathrm{OH}^{-}(\mathrm{M})$ concentration. Therefore, the dependency of the process control model using the data of Ejaz had a factor of $6 \log \mathrm{OH}$ while the model based on the data of Mensah has a factor of 12 dependency. This can be seen by the comparison of the solubilities shown in Appendix B (Figure B-1).

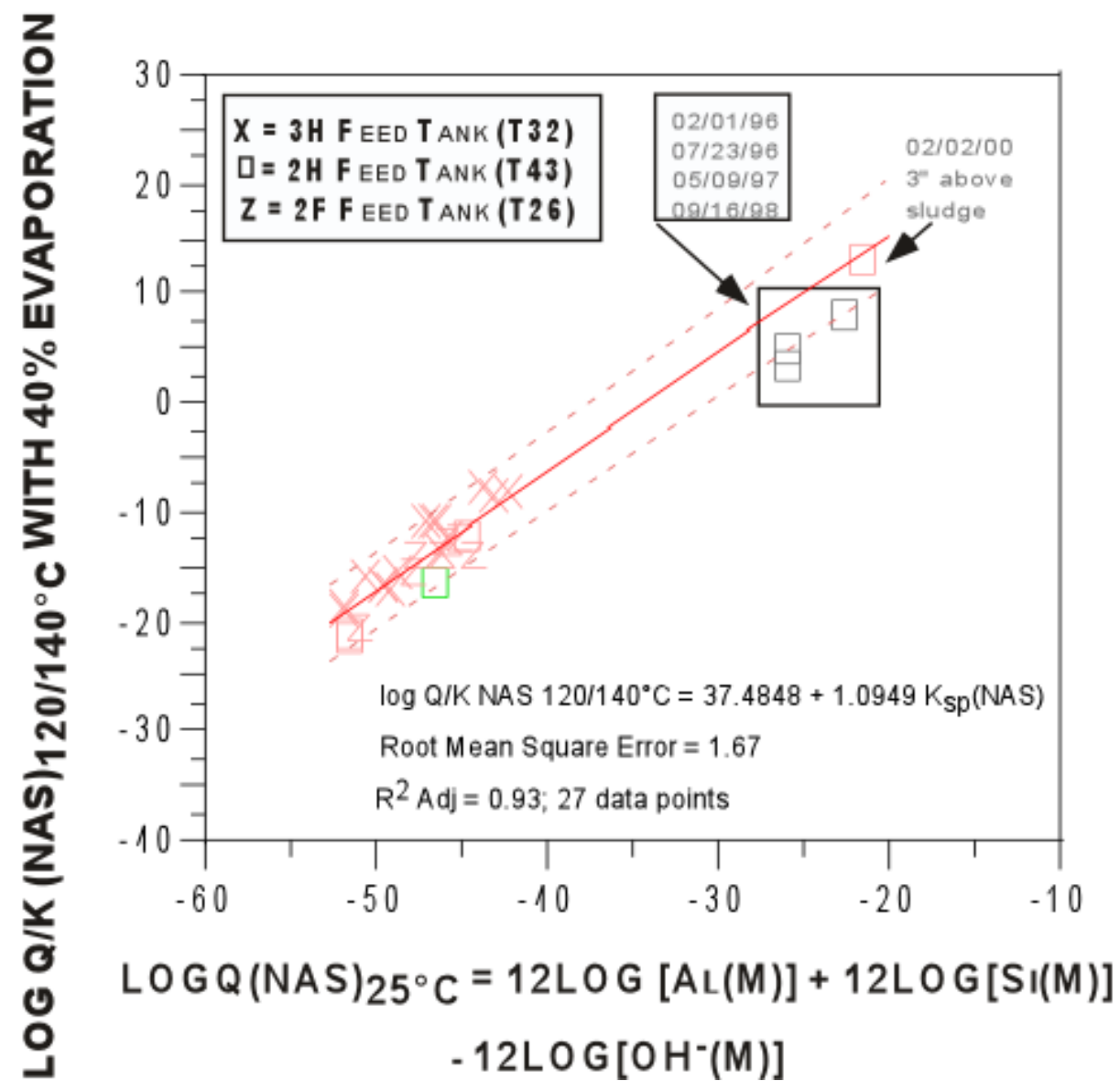

Figure 6. Nominal process control model for the SRS evaporators based on the solubility data of Mensah. ${ }^{8}$ The model is based on the equilibrium between diaspore and NAS ${ }_{\text {gel }}$

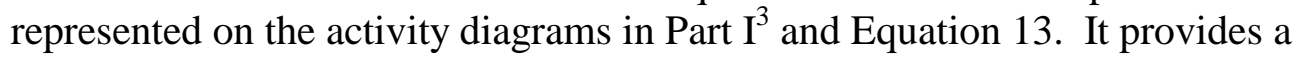
correlation between ambient feed tank chemistry and saturation of the feed tank solutions in the evaporator assuming a nominal $40 \mathrm{wt} \%$ evaporation at temperatures in the range of $120-140^{\circ} \mathrm{C}$. 
WSRC-TR-2002-00330, Rev. 0

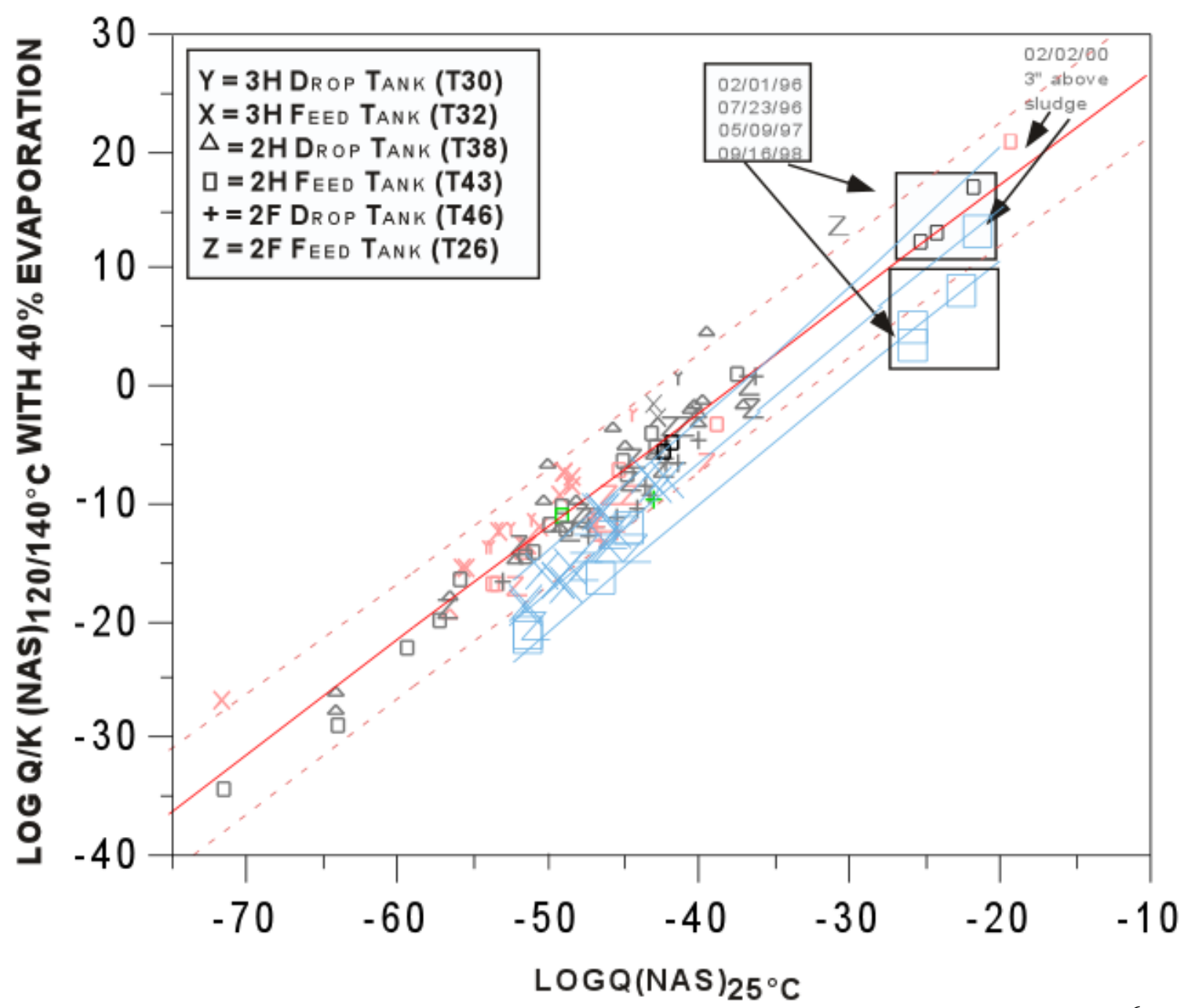

Figure 7. Comparison of the evaporator process control model based on the data of $\mathrm{Ejaz}^{6}$ (red) generated from the Bayer alumina industry aluminosilicate solubility and the data of Mensah et al. ${ }^{8}$ (blue) generated in SRS simulated evaporator solutions.

Since the $\mathrm{NAS}_{\text {gel }}$ solubility measured by Mensah et.al. ${ }^{3}$ is higher than those measured by Ejaz, the evaporator solutions are more undersaturated with respect to NAS gel when modeled using the Mensah et. al. ${ }^{8}$ data. This is demonstrated on the activity diagram representation where it can be seen that the boundary between the $\mathrm{NAS}_{\text {gel }}$ and $\mathrm{AlOOH}$ has shifted to higher $\log \mathrm{SiO}_{2}(\mathrm{aq})$ activities (see Figure 8). This is also seen on the $\log \mathrm{Q} / \mathrm{K}(\mathrm{NAS})_{120 / 140^{\circ} \mathrm{Cwith}} 40 \%$ evaporation vs. $\log$ $\mathrm{Q}(\mathrm{NAS})_{25^{\circ} \mathrm{C}}$ where the process model based on the Mensah data is always calculated to have

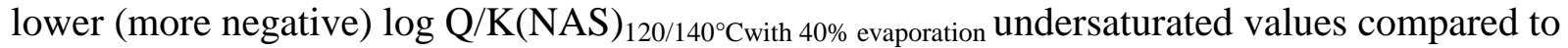
the Ejaz data (see Figure 7). 
WSRC-TR-2002-00330, Rev. 0

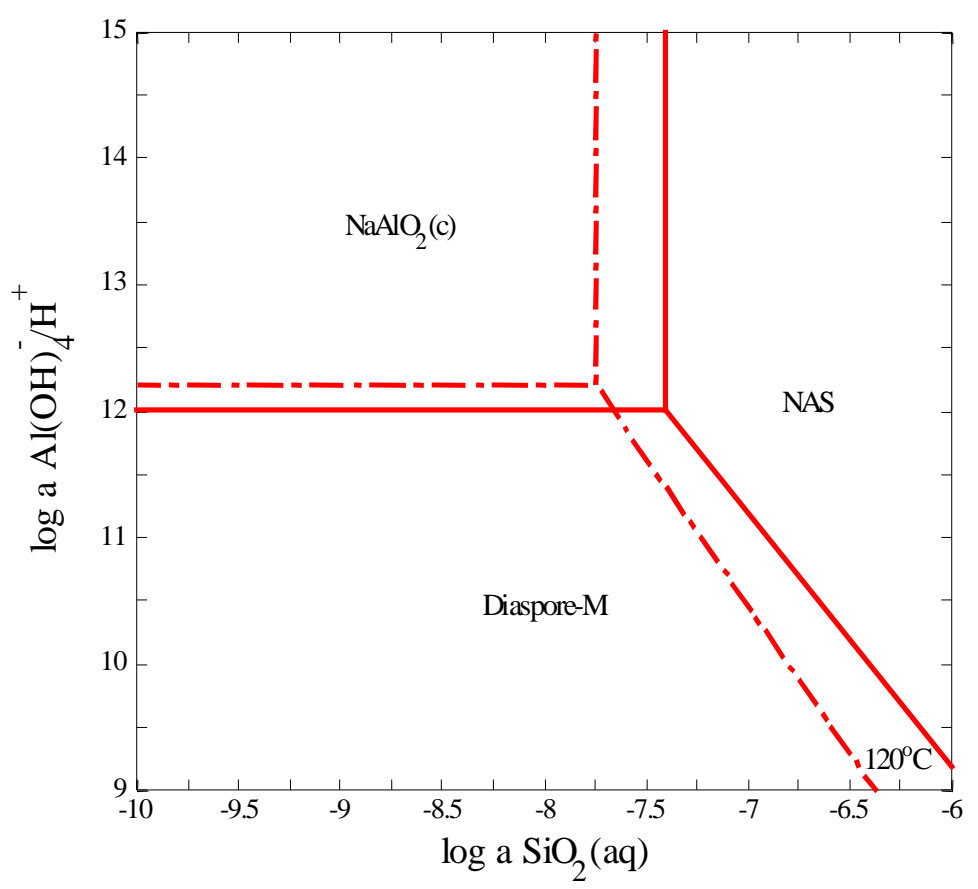

Figure 8 Shift of the $\mathrm{NAS}_{\text {gel }}$-diaspore boundary based on the solubility data of the $\mathrm{NAS}_{\mathrm{gel}}$ in SRS simulated evaporator solutions as measured by Mensah et. al. (solid lines) ${ }^{8}$ compared to the solubility boundary calculated using the data of Ejaz (dashed line). Diagram generated with composition of evaporator solution FTF-046.

\subsection{Sensitivity to Evaporator Operating Temperature}

The nominal evaporator process model was generated using a pooled temperature data set where some of the $\log (\mathrm{Q} / \mathrm{K})_{\text {NAS }}$ values had been calculated at $120^{\circ} \mathrm{C}$ and some had been calculated at $140^{\circ} \mathrm{C}$. The $\log (\mathrm{Q} / \mathrm{K})_{\mathrm{NAS}}$ saturation values had been calculated at $120^{\circ} \mathrm{C}$ for the $\mathrm{SRS} 2 \mathrm{H}$ and $2 \mathrm{~F}$ Evaporator feed tanks since these evaporators ran at $\sim 120^{\circ} \mathrm{C}^{f}$ during the time period modeled in Part $\mathrm{I}^{3}$ of this study. The $\log (\mathrm{Q} / \mathrm{K})_{\text {NAS }}$ saturation values had been calculated at $140^{\circ} \mathrm{C}$ for the SRS $3 \mathrm{H}$ Evaporator since it ran between $135-140^{\circ} \mathrm{C}$ (data from Kent Gilbreath March 2001) during the time period modeled in Part $\mathrm{I}^{3}$ of this study. The pooled data set was used for the following reasons:

- The pooled data spanned the actual operating temperatures of the evaporations that had been performed

- Figure B-1 in Appendix B demonstrates that the solubility of the $\mathrm{NAS}_{\text {gel }}$ as taken from the literature is a linear function of $1 / \mathrm{T}(\mathrm{K})$ for the data examined. 
Currently, the $3 \mathrm{H}$ Evaporator is running at temperatures as high as $\sim 180^{\circ} \mathrm{C}$. Therefore, the applicability of the model over the range of operating conditions for all SRS evaporators, e.g., from $100^{\circ} \mathrm{C}$ to $180^{\circ} \mathrm{C}$, was investigated to further evaluate the dependency of the $\log (\mathrm{Q} / \mathrm{K})_{\mathrm{NAS}}$ saturation values in Figure 6 to temperature.

In order to evaluate the solution equilibrium at elevated temperatures, the solution temperature was incrementally increased in GWB. These calculations simulated evaporation by a stepwise removal of $40 \mathrm{wt} \%$ of the water from the solution. This amount of evaporation changes the solution density from about $1.4 \mathrm{~g} / \mathrm{cm}^{3}$ to about $1.6 \mathrm{~g} / \mathrm{cm}^{3}$, the latter number being the operational target density for the SRS Evaporators.

The temperature variation was evaluated by fitting OLS models to the 27 feed compositions (representing all the evaporator systems) at $120^{\circ} \mathrm{C}, 140^{\circ} \mathrm{C}, 160^{\circ} \mathrm{C}$, and $180^{\circ} \mathrm{C}$. A comparison was then made of the upper and lower temperature bounds to the nominal evaporator process model developed with the pooled $120^{\circ} \mathrm{C} / 140^{\circ} \mathrm{C}$ data set (Equation 13). The relation of the upper temperature bound to the lower temperature bound was also evaluated.

Usage of the Mensah ${ }^{8}$ solubility data at temperatures above $130^{\circ} \mathrm{C}$ is complicated by the rapidity of the kinetics of the formation of NAS gel. However, Figure 5 demonstrates that the NAS $\mathrm{Sel}_{\text {gel }}$ persists up to $175^{\circ} \mathrm{C}$ while the crystalline species are forming. Mensah et. al. ${ }^{8}$ found that they could not "quench" phase pure $\mathrm{NAS}_{\text {gel }}$ samples rapidly enough to prevent the formation of Zeolite-A at temperatures above $130^{\circ} \mathrm{C}$ in $6 \mathrm{M} \mathrm{Na}$ solutions nor above $65^{\circ} \mathrm{C}$ in $12 \mathrm{M} \mathrm{Na}$ solutions.

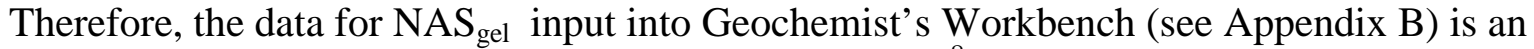
extrapolation of solubility data derived by Mensah et. al. ${ }^{8}$ at $30^{\circ} \mathrm{C}, 65^{\circ} \mathrm{C}$ and $130^{\circ} \mathrm{C}$ in $6 \mathrm{M} \mathrm{Na}$ solutions and extrapolations of NAS gel solubility at $30^{\circ} \mathrm{C}$ and $65^{\circ} \mathrm{C}$ in $12 \mathrm{M} \mathrm{Na}$. An increasingly large field of crystalline $\mathrm{NaAlO}_{2}$ intersects the field of $\mathrm{NAS}_{\text {gel }}$ on the activity (stability) diagrams as temperature is increased (see Figure 9). This can be potentially important when modeling drop tank compositions that are higher in $\mathrm{Na}^{+}$and $\mathrm{Al}(\mathrm{OH})_{4}{ }^{-}$composition as illustrated by the blue stability diagram in Figure 9 overlain on the red feed tank stability diagram. However, Equation 13 applies to both the stable and the metastable equilibrium between $\mathrm{AlOOH}$ and $\mathrm{NAS}_{\mathrm{gel}}$ as shown by the dashed lines on Figure 9. This means that the nominal process model assumes that any evaporator solution in the field of $\mathrm{NaAlO}_{2}$ can metastably precipitate $\mathrm{NAS}_{\text {gel }}$ more rapidly than the stable $\mathrm{NaAlO}_{2}$ phase. Although kinetics on the precipitation of $\mathrm{NaAlO}_{2}$ is not available, the rapidity of the kinetics of $\mathrm{NAS}_{\text {gel }}$ precipitation observed by Mensah et. al. ${ }^{8}$ and the researchers at $\mathrm{ORNL}^{29}$ supports this assumption. 
WSRC-TR-2002-00330, Rev. 0

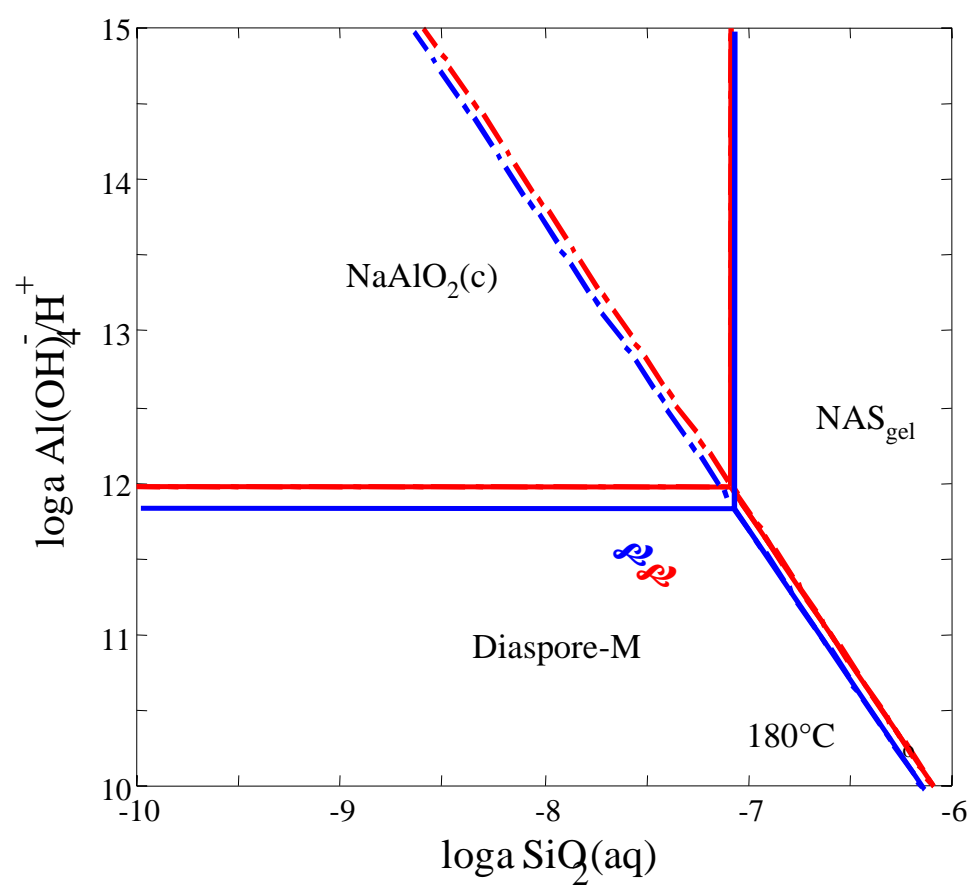

Figure 9. Metastable extension of the equilibrium between $\mathrm{AlOOH}$ and $\mathrm{NAS}_{\text {gel }}$ into the stability field of $\mathrm{NaAlO}_{2}$ for feed tank samples HTK-480-482 (red) and drop tank samples HTK-505-507 (blue) at $180^{\circ} \mathrm{C}$.

In order to evaluate the temperature effects on the nominal process control model, the log $(\mathrm{Q} / \mathrm{K})_{\text {NAS }}$ values were calculated at $120^{\circ} \mathrm{C}$ for the 27 feed tank compositions. The $120^{\circ} \mathrm{C}$ temperature represents the lower bounding temperature at $40 \mathrm{wt} \%$ evaporation (Equation 14). Similarly, the $\log (\mathrm{Q} / \mathrm{K})_{\text {NAS }}$ values were computed for all feed tank compositions at $180^{\circ} \mathrm{C}$ and 40 wt \% evaporation to provide an upper bound for evaporator operations (Equation 17).

Calculations at $140^{\circ} \mathrm{C}$ and $160^{\circ} \mathrm{C}$ and $40 \mathrm{wt} \%$ evaporation are provided as intermediate cases (Equation 15 and Equation 16).

Equation $14 \log \mathrm{Q} / \mathrm{K}_{\left(\mathrm{NAS} @ 120^{\circ} \mathrm{C}\right)}=37.1861+1.1012 \log \mathrm{Q}(\mathrm{NAS})_{25^{\circ} \mathrm{C}} ; \mathrm{R}^{2}=0.96$

Equation $15 \log \mathrm{Q} / \mathrm{K}_{\left(\mathrm{NAS} @ 140^{\circ} \mathrm{C}\right)}=38.0360+1.1000 \log \mathrm{Q}(\mathrm{NAS})_{25^{\circ} \mathrm{C}} ; \mathrm{R}^{2}=0.96$

Equation $16 \log \mathrm{Q} / \mathrm{K}_{\left(\mathrm{NAS} @ 160^{\circ} \mathrm{C}\right)}=37.7169+1.0926 \log \mathrm{Q}(\mathrm{NAS})_{25^{\circ} \mathrm{C}} ; \mathrm{R}^{2}=0.96$

Equation $17 \log \mathrm{Q} / \mathrm{K}_{\left(\mathrm{NAS} @ 180^{\circ} \mathrm{C}\right)}=35.6447+1.0781 \log \mathrm{Q}(\mathrm{NAS})_{25^{\circ} \mathrm{C}} ; \mathrm{R}^{2}=0.96$

Comparison of Equation 13 to Equation 14 and Equation 15 indicates that the response of Equation 13 is intermediate between Equation 14 and Equation 15 since 12 solution $\log (\mathrm{Q} / \mathrm{K})_{\mathrm{NAS}}$ values were calculated at $120^{\circ} \mathrm{C}$ while the remaining 15 solution $\log (\mathrm{Q} / \mathrm{K})_{\text {NAS }}$ values were calculated at $140^{\circ} \mathrm{C}$. Comparison of Equation 14 and Equation 15 indicates that the slopes of the low temperature $\left(120^{\circ} \mathrm{C}\right)$ saturation correlation and the high temperature $\left(180^{\circ} \mathrm{C}\right)$ saturation correlation differ by 0.023 . The main difference in the prediction of saturation at the lower 
temperature $\left(120^{\circ} \mathrm{C}\right)$ and upper temperature $\left(180^{\circ} \mathrm{C}\right)$ evaporator operating temperature bound is expressed in the intercept term that is 1.54 smaller at the higher temperature, e.g. the $\mathrm{NAS}_{\text {gel }}$ is more soluble at higher temperature.

Due to the similarity of the slopes of Equation 13 through Equation 17, one can solve these equations at a fixed $\log \mathrm{Q}(\mathrm{NAS}){ }_{25^{\circ} \mathrm{C}}$ and demonstrate that the $120^{\circ}, 140^{\circ} \mathrm{C}, 160^{\circ} \mathrm{C}$, and $180^{\circ} \mathrm{C}$ variation in $\log \mathrm{Q} / \mathrm{K}_{(\mathrm{NAS})}$ varies little with temperature (see Table IV). In this case a $\log$ $\mathrm{Q}(\mathrm{NAS})_{25^{\circ} \mathrm{C}}$ of -30.00 was chosen to demonstrate that the there is little impact on the calculated $\log \mathrm{Q} / \mathrm{K}(\mathrm{NAS}){ }_{25^{\circ} \mathrm{C}}$ between $120-180^{\circ} \mathrm{C}$. The lack of a strong dependency of the aluminosilicate saturation on temperature was previously demonstrated in Part $\mathrm{III}^{5}$ of this study.

Table IV. Sensitivity of $\log (\mathrm{Q} / \mathrm{K})_{\mathrm{NAS}}$ at Varying Evaporator Operating Temperatures

\begin{tabular}{|l|c|c|}
\hline \multicolumn{1}{|c|}{ Temperature } & Equations Used & $\begin{array}{c}\text { Corresponding } \\
\log \mathbf{Q} / \mathbf{K}_{(\mathbf{N A S})} \text { at } \\
\log \mathbf{Q}(\mathbf{N A S})_{\mathbf{2 5}}{ }^{\circ} \mathrm{C} \\
\mathbf{o f} \mathbf{- 3 0 . 0 0}\end{array}$ \\
\hline $140^{\circ} \mathrm{C}$ & Equation 15 & +5.04 \\
\hline $160^{\circ} \mathrm{C}$ & Equation 16 & +4.94 \\
\hline $120 / 140^{\circ} \mathrm{C}$ pooled & Equation 13 & +4.64 \\
\hline $120^{\circ} \mathrm{C}$ & Equation 14 & +4.15 \\
\hline $180^{\circ} \mathrm{C}$ & Equation 17 & +3.30 \\
\hline
\end{tabular}

\subsection{Sensitivity to Percent Evaporation}

The nominal evaporator process model given in Equation 13 was generated assuming an evaporation of $40 \mathrm{wt} \%$. During routine operation the evaporators do not always achieve $40 \mathrm{wt}$ $\%$. This is especially true when the evaporator solutions approach their operational target density of $1.6 \mathrm{~g} / \mathrm{cm}^{3}$. Therefore, upper and lower bounds on evaporation were calculated spanning 0 wt $\%$ to 60 wt $\%$ evaporations. Since the temperature effects on the model were shown (see Section 5.2) to be minimal, the varying evaporation percentages are calculated using the pooled $120^{\circ} \mathrm{C} / 140^{\circ} \mathrm{C}$ data set. The calculation for the 27 data points from the evaporator feed tanks gives the following equations for a variety of other evaporation rates:

Equation $18 \log \mathrm{Q} / \mathrm{K}_{(\mathrm{NAS} @ 0 \mathrm{wt} \% \text { evaporation })}=32.9085+1.0832 \log \mathrm{Q}(\mathrm{NAS})_{25^{\circ} \mathrm{C}} ; \mathrm{R}^{2}=0.94$

Equation $19 \log \mathrm{Q} / \mathrm{K}_{(\mathrm{NAS} @ 10 \mathrm{wt} \% \text { evaporation })}=33.8403+1.0856 \log \mathrm{Q}(\mathrm{NAS})_{25^{\circ} \mathrm{C}} ; \mathrm{R}^{2}=0.94$

Equation $20 \quad \log \mathrm{Q} / \mathrm{K}_{(\mathrm{NAS} @ 20 \mathrm{wt} \% \text { evaporation })}=34.8898+1.088 \log \mathrm{Q}(\mathrm{NAS})_{25^{\circ} \mathrm{C}} ; \quad \mathrm{R}^{2}=0.94$

Equation $21 \quad \log \mathrm{Q} / \mathrm{K}_{(\mathrm{NAS} @ 30 \text { wt \% evaporation })}=36.0886+1.0913 \log \mathrm{Q}(\mathrm{NAS})_{25^{\circ} \mathrm{C}} ; \mathrm{R}^{2}=0.94$

Equation $22 \log \mathrm{Q} / \mathrm{K}_{(\mathrm{NAS} @ 50 \text { wt \% evaporation })}=39.1522+1.0992 \log \mathrm{Q}(\mathrm{NAS})_{25^{\circ} \mathrm{C}} ; \mathrm{R}^{2}=0.94$

Equation $23 \log \mathrm{Q} / \mathrm{K}_{\text {(NAS @ } 60 \text { wt \% evaporation })}=41.2160+1.1045 \log \mathrm{Q}(\mathrm{NAS})_{25^{\circ} \mathrm{C}} ; \mathrm{R}^{2}=0.94$ 
Due to the similarity of the slopes of Equation 13 and Equation 18 through Equation 23, one can solve these equations at a fixed $\log \mathrm{Q}(\mathrm{NAS}){ }_{25^{\circ} \mathrm{C}}($ see Table V). As with the temperature sensitivity analysis a $\log \mathrm{Q}(\mathrm{NAS})_{25^{\circ} \mathrm{C}}$ of -30.00 was chosen to demonstrate that the $10-60 \%$ evaporation data fell within the $95 \%$ error bands associated with Equation 13. There is a stronger dependency of the aluminosilicate saturation on evaporation than on temperature as was demonstrated in Part $\mathrm{III}^{5}$ of this study.

The sensitivity of aluminosilicate saturation to evaporation can also be accessed by solving Equation 13 and Equation 18 through Equation 23 at $\log \mathrm{Q} / \mathrm{K}_{\text {(NAS }}=0$ and fitting an OLS regression to the calculated $\log \mathrm{Q}(\mathrm{NAS}){ }_{25^{\circ} \mathrm{C}}$ (see Figure 10). The OLS regression takes the form

Equation $24 \log \mathrm{Q}(\mathrm{NAS})_{25^{\circ} \mathrm{C}}=-32.1114-0.1119(\%$ Evaporation $)+0.0165\left(\right.$ Operating Temp $\left.{ }^{\circ} \mathrm{C}\right)$ with an $\mathrm{R}^{2}=0.95$ and $\mathrm{RMS}$ of 0.52 .

The coefficients in Equation 24 demonstrate that evaporation and operating temperature have opposite effects, increased evaporation causes decreased solubility of components while increased temperature causes increased solubility of components. The coefficients in Equation 24 demonstrate that evaporation is a factor of 10 more significant than operating temperature. Due to the insignificance of the temperature term, and the fact that higher temperature causes increased solubility of components, the temperature term can be eliminated from Equation 24 which then becomes:

Equation $25 \quad \log \mathrm{Q}(\mathrm{NAS})_{25^{\circ} \mathrm{C}}=-29.9434-0.1092(\%$ Evaporation $)$

with an $\mathrm{R}^{2}=0.93$ and $\mathrm{RMS}$ of 0.57 .

Equation 25 can be implemented once the chemistry of a given solution is known by monitoring percent evaporation.

Table V. Sensitivity of Log $(\mathrm{Q} / \mathrm{K})_{\mathrm{NAS}}$ at Varying Evaporations

\begin{tabular}{|l|c|c|}
\hline Percent Evaporation & Equations Used & $\begin{array}{c}\text { Corresponding } \\
\mathbf{L o g} \mathbf{Q} / \mathbf{K}_{(\mathbf{N A S})} \text { at } \\
\log \mathbf{Q}(\mathbf{N A S})_{25} \mathbf{C}^{\mathbf{C}} \\
\mathbf{o f ~} \mathbf{- 3 0 . 0 0}\end{array}$ \\
\hline 60 & Equation 23 & +8.08 \\
\hline 50 & Equation 22 & +6.18 \\
\hline $40 \%$ nominal & Equation 13 & +4.64 \\
\hline 30 & Equation 21 & +3.35 \\
\hline 20 & Equation 20 & +2.24 \\
\hline 10 & Equation 19 & +1.27 \\
\hline 0 & Equation 18 & +0.41 \\
\hline
\end{tabular}


WSRC-TR-2002-00330, Rev. 0

Table VI. Sensitivity of Aluminosilicate Supersaturation to Evaporation and Temperature

\begin{tabular}{|c|c|c|c|}
\hline Temperature $\left({ }^{\circ} \mathrm{C}\right)$ & Percent Evaporation & Equations Used & $\begin{array}{c}\text { Corresponding } \\
\log Q(N A S)_{25^{\circ} \mathrm{C}} \\
\text { at } \log Q / K_{(\mathrm{NAS})} \\
\text { of Zero }\end{array}$ \\
\hline 120/140 pooled* & 60 & Equation 23 & -37.32 \\
\hline 120/140 pooled* & 50 & Equation 22 & -35.62 \\
\hline 120 & $40 \%$ nominal & Equation 14 & -33.77 \\
\hline 120/140 pooled* & $40 \%$ nominal & Equation 13 & -34.24 \\
\hline 140 & $40 \%$ nominal & Equation 15 & -34.57 \\
\hline 160 & $40 \%$ nominal & Equation 16 & -34.52 \\
\hline 180 & $40 \%$ nominal & Equation 17 & -33.06 \\
\hline 120/140 pooled* & 30 & Equation 21 & -33.07 \\
\hline 120/140 pooled* & 20 & Equation 20 & -32.06 \\
\hline 120/140 pooled* & 10 & Equation 19 & -31.17 \\
\hline 120/140 pooled* & 0 & Equation 18 & -30.38 \\
\hline
\end{tabular}

$*$ an average value of $130^{\circ} \mathrm{C}$ is used to generate Figure 10

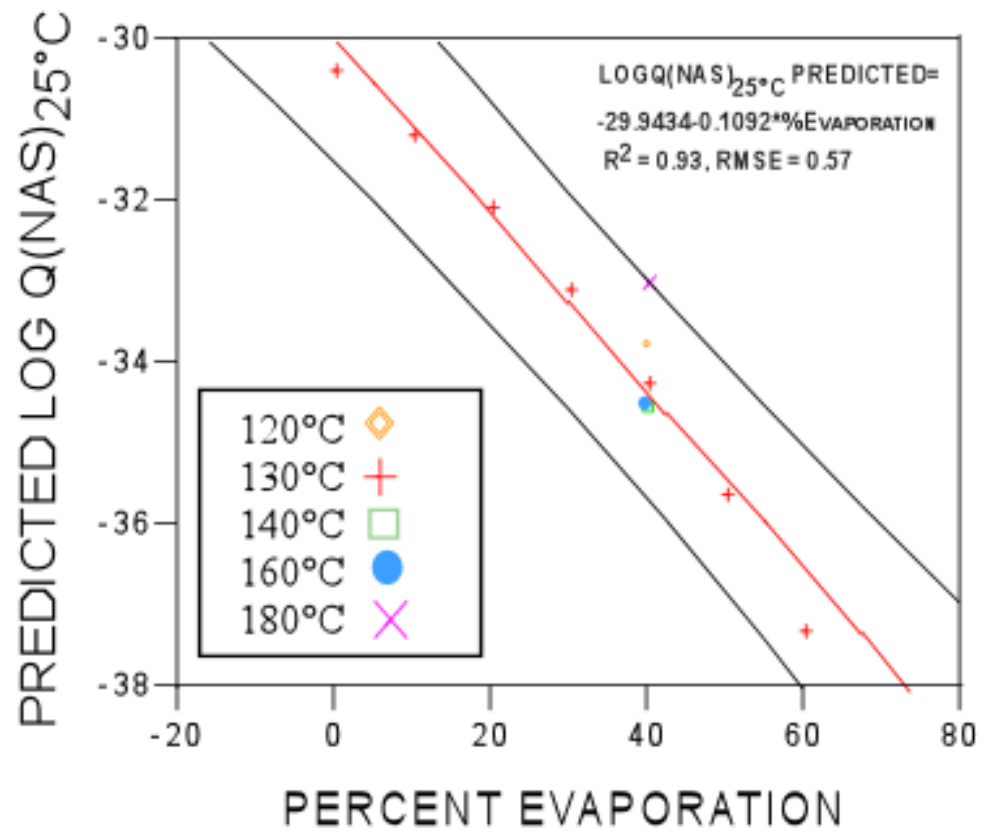

Figure 10. Relation of $\log \mathrm{Q}(\mathrm{NAS})_{25^{\circ} \mathrm{C}}$ to percent evaporation and evaporator operating temperature. 
WSRC-TR-2002-00330, Rev. 0

\subsection{VALIDATION OF NOMINAL PROCESS CONTROL MODEL}

\subsection{Orthogonal Latin Hypercube (OLH) Analysis}

The maximum and minimum values given in Table VII were used to generate the nominal process model given in Equation 13 and shown in Figure 6. In order to validate Equation 13, an Orthogonal Latin Hypercube (OLH) matrix was developed using the maximum and minimum compositions and temperatures shown in Table VII. A nominal evaporation of $40 \%$ was used for all the calculations.

Table VII. Ranges Modeled in Section 5.0 (Feed Tank Data from 1995-2002)

\begin{tabular}{|l|c|c|}
\hline & Minimum (M) & Maximum (M) \\
\hline $\mathrm{Al}(\mathrm{M})$ & 0.11 & 1.1 \\
\hline $\mathrm{Cl}(\mathrm{M})$ & 0.003 & 0.02 \\
\hline $\mathrm{CO}_{3}(\mathrm{M})$ & 0.005 & 0.43 \\
\hline $\mathrm{C}_{2} \mathrm{O}_{4}(\mathrm{M})$ & 0.0025 & 0.0063 \\
\hline $\mathrm{F}(\mathrm{M})$ & 0.0027 & 0.01 \\
\hline $\mathrm{Fe}(\mathrm{M})$ & 0.005 & 0.36 \\
\hline $\mathrm{NO}_{2}(\mathrm{M})$ & 0.80 & 2.5 \\
\hline $\mathrm{NO}_{3}(\mathrm{M})$ & 0.89 & 3.42 \\
\hline $\mathrm{OH}(\mathrm{M})$ & 1.95 & 10.4 \\
\hline $\mathrm{K}(\mathrm{M})$ & 0.01 & 0.085 \\
\hline $\mathrm{PO}_{4}(\mathrm{M})$ & 0.006 & 0.013 \\
\hline $\mathrm{SO}_{4}(\mathrm{M})$ & 0.0063 & 0.03 \\
\hline $\mathrm{Si}_{(\mathrm{M})}$ & $2.00 \mathrm{E}-05$ & 0.143 \\
\hline $\mathrm{U}(\mathrm{M})$ & $1.07 \mathrm{E}-05$ & 0.002 \\
\hline $\mathrm{Na}_{\text {calc }}(\mathrm{M})$ & 5.21 & 17.67 \\
\hline $\mathrm{Temperature}\left({ }^{\circ} \mathrm{C}\right)$ & 120 & 140 \\
\hline Evaporation Fraction & 0.4 & 0.4 \\
\hline
\end{tabular}

Note that in the reproted minimum [Fe] in the feed tank was $0.0 \mathrm{M}$. Therefore, one half the detection limit for this element was substituted for the minimum $[\mathrm{Fe}]$. The $\mathrm{Na}^{+}{ }_{\text {calc }}(\mathrm{M})$ values shown in Table VII are defined by the remaining solution species via the relationship given in Equation 4.

During this study it was determined that design of the OLH factor space was dependent upon whether the solution concentrations exhibited a lognormal or Gaussian distribution. If the solution concentrations are lognormal, then the Orthogonal Latin Hypercube (OLH) designs should be developed using $\log ([])$ values. If the solution concentrations are Gaussian in nature then the OLH designs should be developed on the molar compositions shown in Table VII and not the log of these values. In order to validate the nominal process control model (Equation 13), the distribution of the 27 SRTC feed solutions in terms of $\mathrm{OH}^{-}(\mathrm{M})$ and $\mathrm{Na}^{+}$calc $(\mathrm{M})$ values calculated from measured analyses were examined. Figure 11 demonstrates that the distributions of the measured data were Gaussian and hence the validation was performed by designing the 
OLH simulated solutions based on the molar concentrations in Table VII and not the log of the concentrations.

An OLH design of 513 simulated solutions at temperatures varying between $120-140^{\circ} \mathrm{C}$ at $40 \%$ nominal evaporation was calculated. The OLH design can, however, create unrealistic combinations of evaporation and sodium content. For example, the OLH may have an evaporation of $40 \%$ for a starting sodium content of $16 \mathrm{M}$. This evaporation would yield an unachievably high final sodium concentration. Therefore, a screen was developed to eliminate these unrealistic combinations.

First, it is assumed that the highest possible final sodium concentration in the evaporators is $19 \mathrm{M}$. This corresponds to $50 \%$ wt $\mathrm{NaOH}$ in water. Second, the maximum possible evaporation is calculated from the starting sodium concentration:

Equation $26 \quad$ Max Evap $=1-\frac{N a(M)}{19}$

where $\mathrm{Na}(\mathrm{M})$ is the initial sodium content.

Finally, the calculated maximum evaporation is compared to the evaporation in the OLH. If the OLH evaporation is higher than the calculated maximum, this combination of evaporation and composition is excluded from the OLH.

$\mathrm{OH}^{-}(\mathrm{M})$ in Feed Tank Solutions Used in Development of Equation 13

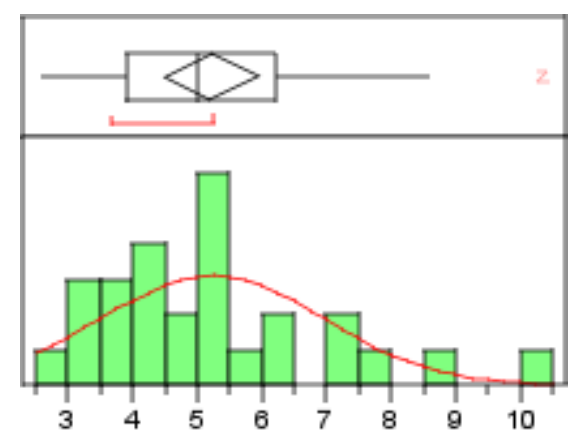

$\mathrm{Na}^{+}$calc $(\mathrm{M})$ in Feed Tank Solutions Used in Development of Equation 13

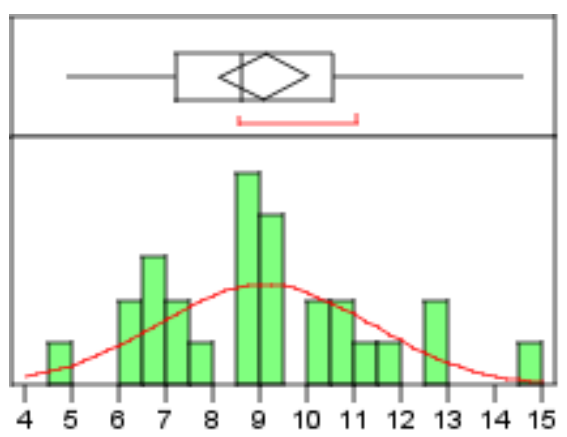

Figure 11. Gaussian distribution of $\mathrm{OH}^{-}(\mathrm{M})$ and $\mathrm{Na}^{+}$calc $(\mathrm{M})$ in feed tank solutions used to define the nominal process model. The red line represents an ideal Gaussian distribution.

The Equation 26 screening tool eliminated 258 of the 513 OLH simulated solutions leaving another 255 for validation of the nominal process model, Equation 13. $\log Q\left(N A S_{g e l}\right)_{25^{\circ} \mathrm{C}}$ values were calculated for the 255 simulated solutions from Equation 12 and these were fitted to the 
WSRC-TR-2002-00330, Rev. 0

255 calculated $\log (Q / K)_{N A S 120-140^{\circ} \mathrm{C} / 40 \% \text { evap }}$ values determined from GWB via an ordinary least squares (OLS) analysis. The OLS generated the validation Equation 27 given below:

Equation $27 \log (Q / K)_{N A S 120-140^{\circ} \mathrm{C} / 40 \% \text { evap }}=\begin{aligned} & 37.3584+1.0839(12 \log [A l(M)]+12 \log [\operatorname{Si}(M)] \\ & -12 \log [O H(M)])\end{aligned}$

Equation 13 the nominal process control model is shown below to be very similar in slope and intercept.

Equation $13 \log (Q / K)_{N A S 120-140^{\circ} \mathrm{C} / 40 \% \text { evap }}=\begin{aligned} & 37.4848+1.0949(12 \log [A l(M)]+12 \log [\operatorname{Si}(M)] \\ & -12 \log [O H(M)])\end{aligned}$

To assess how well Equation 13 fits the validation data generated by the OLH, the residuals calculated from the difference between this equation and the GWB OLH predictions can be assessed (see Figure 12). The distribution of the residuals are shown to be Gaussian and to vary around the prediction by $\pm 4 \log (Q / K)_{N A S 120-140^{\circ} \mathrm{C} / 40 \% \text { evap }}$.

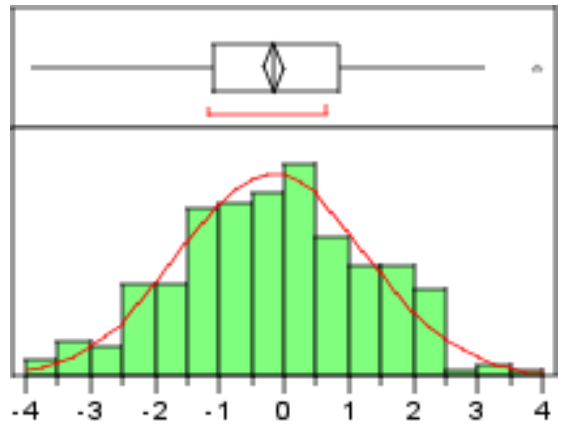

\begin{tabular}{|c|c|c|c|c|}
\hline \multicolumn{3}{|c|}{ Quantiles } & \multicolumn{2}{|l|}{ Moments } \\
\hline $100.0 \%$ & maximum & 3.940 & Mean & -0.162415 \\
\hline $99.5 \%$ & & 3.702 & Std Dev & 1.4423091 \\
\hline $97.5 \%$ & & 2.402 & Std Err Mean & 0.0903209 \\
\hline $90.0 \%$ & & 1.780 & upper $95 \%$ Mean & 0.015458 \\
\hline $75.0 \%$ & quartile & 0.835 & low er $95 \%$ Mean & -0.340289 \\
\hline $50.0 \%$ & median & -0.167 & $\mathrm{~N}$ & 255 \\
\hline $25.0 \%$ & quartile & -1.103 & & \\
\hline $10.0 \%$ & & -2.099 & & \\
\hline $2.5 \%$ & & -3.110 & & \\
\hline $0.5 \%$ & & -3.828 & & \\
\hline $0.0 \%$ & minimum & -3.859 & & \\
\hline
\end{tabular}

Figure 12 Assessment of the nominal process control model (Equation 13) to the OLH validation data.

The nominal process control model generated via the OLH analysis, e.g. Equation 27, is also compared to the nominal feed tank process control model, e.g. Equation 13, for the 27 feed tank compositions used to generate the nominal process control model (see Figure 13). Figure 13 indicates a slope of $\sim 1$ and an intercept of $\sim 0$ and an $\mathrm{R}^{2}=1.0$ for an OLS regression between Equation 13 and Equation 27. Figure 13 validates the nominal process control model based on the highly leveraged feed tank data and demonstrates that the OLH statistical approach can be used to translate between statistically designed simulated SRS evaporator solutions and actual tank data. 


\subsection{Drop Tank Data}

The nominal process model given in Equation 13] and shown in Figure 6 was generated using the 27 feed tank solutions analyzed by SRTC (see Table I and Table II). The corresponding 22 drop tank solution analyses generated by SRTC (see Table III) were used to validate the nominal process model developed from the 27 feed tank solutions. The OLS fit to the 22 drop tank solutions analyzed between 1995-2002 gives the following equation of best fit with an $\mathrm{R}^{2}$ of 0.85 :

Equation $28 \log (Q / K)_{N A S 120-140^{\circ} \mathrm{C} / 40 \% \text { evap }}=\begin{aligned} & 35.1973+1.0306(12 \log [A l(M)]+12 \log [\operatorname{Si}(M)] \\ & -12 \log [O H(M)])\end{aligned}$

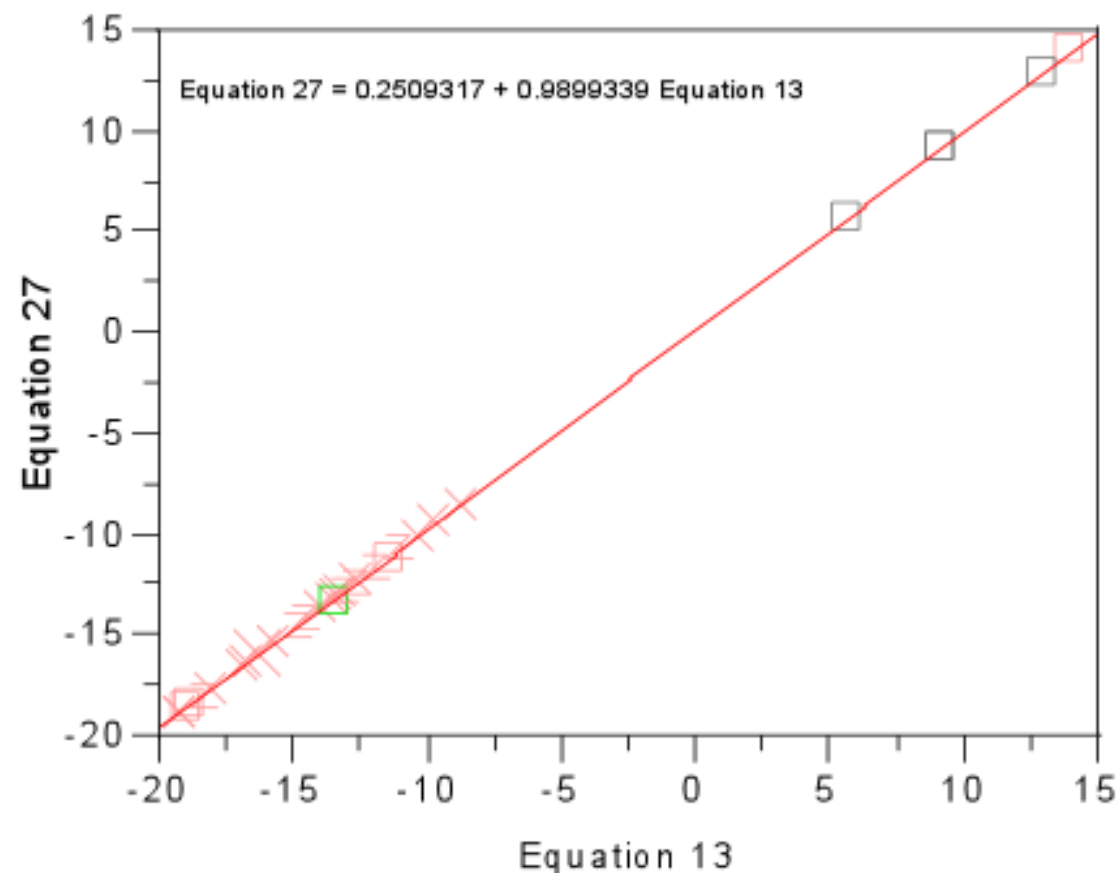

Figure 13. Correlation between the nominal process control model developed based on SRS evaporator feed tank data between 1995-2002 (Equation 13) and a set of simulated evaporator solutions generated by a composition and temperature space filling OLH design (Equation 27).

Comparison of Equation 13, the nominal process control model based on the feed tanks, to Equation 28, the nominal process control model based on the drop tanks, indicates a slope of $<1.0$, e.g. 0.94 and an intercept of $\sim 0$ (Figure 14). The slope $<1.0$ demonstrates a bias in the data from the drop tanks relative to the feed tanks.

The bias in the drop tank data is also shown in Figure 15 where the distribution of the differences in the predictions between Equation 13 (the nominal process control model) and the GWB predictions for the drop tank validation chemistries shows that the drop tanks are less supersaturated with respect to $\mathrm{NAS}_{\text {gel, }}$ e.g. undersaturated with respect to $\log (\mathrm{Q} / \mathrm{K})$. This 
indicates that a feed tank close to saturation, e.g. $\log (\mathrm{Q} / \mathrm{K})_{\mathrm{NAS}} \sim 0$ may supersaturate at the elevated evaporator temperatures with respect to $\mathrm{NAS}_{\mathrm{gel}}$ but then precipitate in the drop tank. This is confirmed by recent findings of NAS crystalline products in the evaporator drop tanks. ${ }^{52,53}$ Precipitation in the evaporator is precluded since the $\log (\mathrm{Q} / \mathrm{K})_{\text {NAS }}$ for these solutions is undersaturated at the evaporator operating temperature. Due to these complexities, the drop tank data was used for validation rather than for modeling.

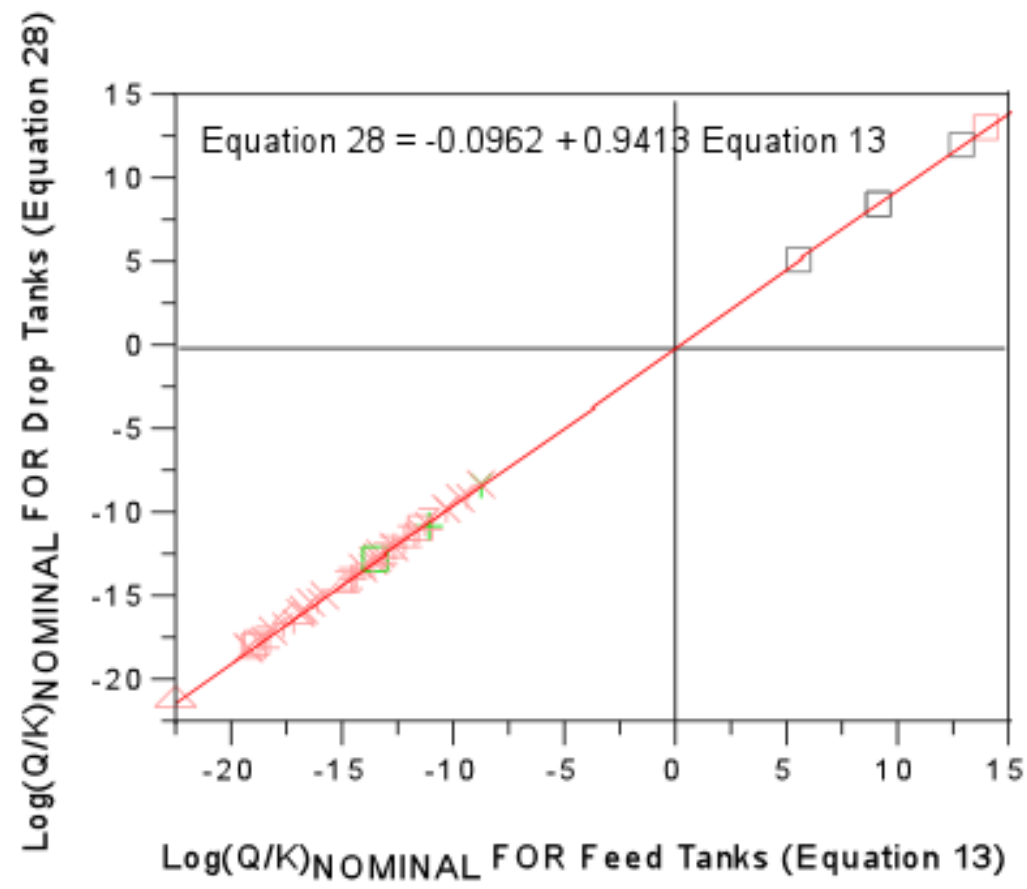

Figure 14. Bias in supersaturation between drop tank and feed tank data.

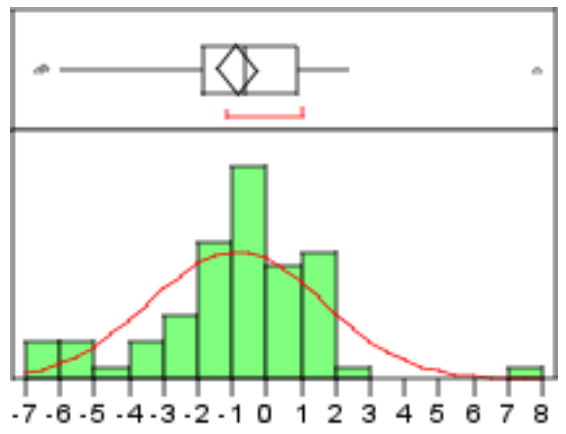

\begin{tabular}{|lrlrr|}
\hline Quantiles & \multicolumn{3}{l|}{ Moments } \\
\cline { 1 - 1 } $100.0 \%$ & maximum & 7.856 & Mean & -0.866987 \\
$99.5 \%$ & 7.856 & Std Dev & 2.5113417 \\
$97.5 \%$ & 4.403 & Std Err Mean & 0.3139177 \\
$90.0 \%$ & & 1.718 & upper 95\% Mean & -0.239673 \\
$75.0 \%$ & quartile & 0.876 & low er 95\% Mean & -1.494302 \\
$50.0 \%$ & median & -0.663 & $\mathrm{~N}$ & 64 \\
$25.0 \%$ & quartile & -1.858 & & \\
$10.0 \%$ & & -5.129 & & \\
$2.5 \%$ & & -6.495 & & \\
$0.5 \%$ & & -6.587 & & \\
$0.0 \%$ & minimum & -6.587 & & \\
\end{tabular}

Figure 15. Assessment of the nominal process control model (Equation 13) to the drop tank validation data. 
WSRC-TR-2002-00330, Rev. 0

\subsection{DEVELOPMENT OF AN EXPANDED EVAPORATOR PROCESS CONTROL MODEL}

\subsection{Orthogonal Latin Hypercube Design}

The validation of the nominal process control model discussed in Section 6.1 demonstrates that the OLH statistical approach can be used to translate between statistically designed simulated SRS evaporator solutions and actual tank data. Since the exact evaporations and temperatures could only be approximated in the nominal evaporator process control model, a second expanded OLH statistical design can be used to incorporate wider composition ranges, temperature sensitivity, and percent evaporation sensitivity into an expanded process control model.

Reasonable maximum concentrations for $\left[\mathrm{NO}_{2}\right],\left[\mathrm{NO}_{3}\right]$, and $[\mathrm{OH}]$ in the tank farm were determined $^{f}$ to be $4 \mathrm{M}, 7 \mathrm{M}$, and $16 \mathrm{M}$, respectively. Somewhat wider upper concentration bounds for $\left[\mathrm{NO}_{2}\right],\left[\mathrm{NO}_{3}\right]$, and $[\mathrm{OH}]$ of $6 \mathrm{M}, 7 \mathrm{M}$, and $16 \mathrm{M}$ were used in modeling to investigate the expansion of this range. In addition, the temperature was varied between $100^{\circ} \mathrm{C}$ and $180^{\circ} \mathrm{C}$ and the evaporation percentage between 0 and $80 \%$.

During this study it was determined that design of the OLH factor space was dependent upon whether the solution concentrations exhibited a lognormal or Gaussian distribution. If the solution concentrations are lognormal, then the Orthogonal Latin Hypercube (OLH) designs should be developed using $\log ([])$ values. If the solution concentrations are Gaussian in nature then the OLH designs should be developed on the molar compositions shown in Table VII and not the log of these values. For the nominal evaporator model based on SRTC data from 19952002, it was determined that the solution concentrations were Gaussian rather than lognormal and the OLH design was caculated in molar concentrations.

An analysis of the long term variation of tank farm concentrations between 1973-2001 (see data in Appendix A) demonstrated that the evaporator solution concentrations were lognormal (see Figure 16). Therefore, the OLH space filling designs for the expanded evaporator model were developed using $\ln ([])$ values. These are provided in Table VIII (where because the minimum [Fe] was 0.0 , the minimum concentration for all those shown in the table-which is that for $[\mathrm{U}]$ - was substituted for the minimum $[\mathrm{Fe}])$.

${ }^{f}$ D.T. Hobbs of SRTC 
WSRC-TR-2002-00330, Rev. 0

$\mathrm{OH}^{-}(\mathrm{M})$ in Feed Tank Solutions Over the Last $28 \mathrm{Na}^{+}$calc $(\mathrm{M})$ in Feed Tank Solutions Over the Last Years 28 Years
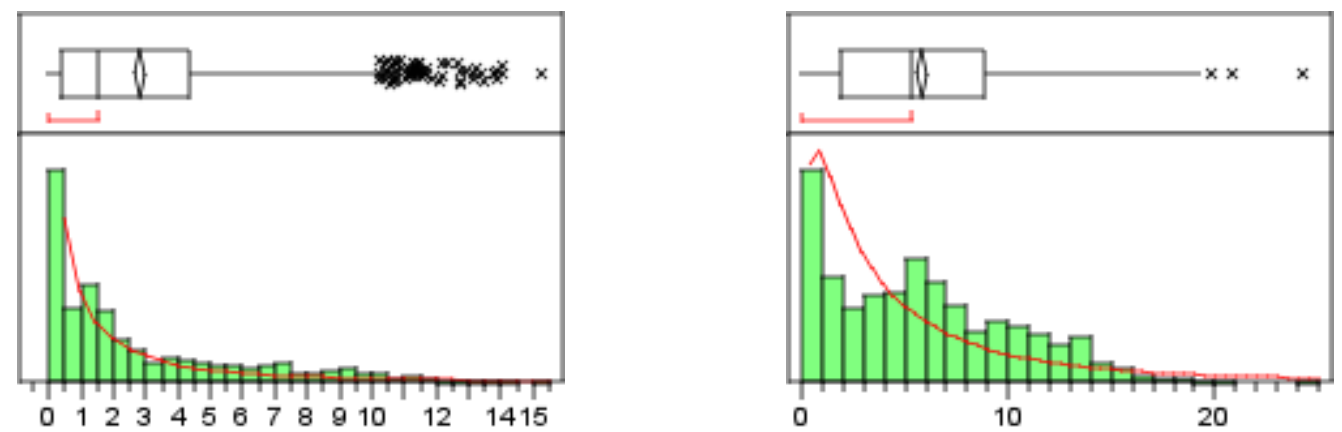

Figure 16. Lognormal distribution of tank farm solutions over 28 years (1973-2001).

Table VIII. Tank Farm Bounding Regions Including Logarithmic Transformations Used in the OLH Statistical Analysis

\begin{tabular}{|l|r|r|r|r|}
\hline & Min & Min (log) & Max & Max (log) \\
\hline $\mathrm{Al}(\mathrm{M})$ & 0.005 & -2.3010 & 4 & 0.6021 \\
\hline $\mathrm{Cl}(\mathrm{M})$ & 0.00020 & -3.6990 & 0.12 & -0.9208 \\
\hline $\mathrm{CO}_{3}(\mathrm{M})$ & 0.005 & -2.3010 & 2.875 & 0.4586 \\
\hline $\mathrm{C}_{2} \mathrm{O}_{4}(\mathrm{M})$ & 0.0005 & -3.3010 & 0.15 & -0.8239 \\
\hline$\left[\mathrm{CO}_{3}\right]+\left[\mathrm{C}_{2} \mathrm{O}_{4}\right]$ & 0.0055 & -2.2596 & 3.025 & 0.4807 \\
\hline $\mathrm{F}(\mathrm{M})$ & 0.00000526 & -5.2840 & 0.2415 & -0.6171 \\
\hline $\mathrm{Fe}(\mathrm{M})$ & 0 & -6.3010 & 0.3581021 & -0.4460 \\
\hline $\mathrm{NO}_{2}(\mathrm{M})$ & 0.0921 & -1.0357 & 6.0 & 0.7782 \\
\hline $\mathrm{NO}_{3}(\mathrm{M})$ & 0.0173 & -1.7620 & 7.0 & 0.8451 \\
\hline$\left[\mathrm{NO}_{2}\right]+\left[\mathrm{NO}_{3}\right]$ & 0.1094 & -0.9610 & 13 & 1.1139 \\
\hline $\mathrm{OH}_{(\mathrm{M})}$ & 0.01 & -2.000 & 16 & 1.2041 \\
\hline $\mathrm{K}(\mathrm{M})^{\mathrm{PO}}(\mathrm{M})$ & 0.001215 & -2.9154 & 0.5 & -0.3010 \\
\hline $\mathrm{SO}{ }_{4}(\mathrm{M})$ & 0.0005 & -3.3010 & 0.145 & -0.8386 \\
\hline $\mathrm{Si}(\mathrm{M})$ & 0.0005 & -3.3010 & 0.8875 & -0.0518 \\
\hline $\mathrm{U}(\mathrm{M})$ & 0.00002136 & -4.6716 & 0.1785714 & -0.7482 \\
\hline $\mathrm{Na}^{(M)}$ & $5.00 \mathrm{E}-07$ & -6.3010 & 0.0155 & -1.8097 \\
\hline Temperature $\left({ }^{\circ} \mathrm{C}\right)$ & 0.2015 & -0.6957 & 23 & 1.3617 \\
\hline Evap. Fraction & 100 & & 180 & \\
\hline
\end{tabular}

The molar concentrations in the design matrix were then transformed into the corresponding molal concentrations per Equation 2 through Equation 4 and then the molal concentrations were analyzed with the REACT subroutine of GWB. 
As shown in Section 6.1, the OLH design can create unrealistic combinations of evaporation and sodium content. For example, the OLH may have an evaporation of $40 \%$ for a starting sodium content of $16 \mathrm{M}$. This evaporation would yield an unachievably high final sodium concentration. Therefore, a screen was developed to eliminate these unrealistic combinations.

First, it is assumed that the highest possible final sodium concentration in the evaporators is $19 \mathrm{M}$. This corresponds to $50 \mathrm{wt} \% \mathrm{NaOH}$ in water. Second, the maximum possible evaporation is calculated from the starting sodium concentration from :

Equation $26 \quad$ Max Evap $=1-\frac{N a(M)}{19}$

where $\mathrm{Na}(\mathrm{M})$ is the initial sodium content.

Finally, the calculated maximum evaporation is compared to the evaporation in the OLH. If the OLH evaporation is higher than the calculated maximum, this combination of evaporation and composition is excluded from the OLH.

This maximum evaporation screening tool elimated 122 of the original 513 design points. The GWB results for the remaining 401 data points are provided in Figure 17. The results do an excellent job of covering the saturation points (i.e., $\log (\mathrm{Q} / \mathrm{K})_{\mathrm{NAS}}=0$ ) for the $\mathrm{NAS}_{\mathrm{gel}}$ phase as shown in Figure 17. Also the biases in the model predictions appear to be reasonably distributed for the optimized design; noting that all deviations shown are biases and not the random measurement errors normally associated with such plots. 
WSRC-TR-2002-00330, Rev. 0

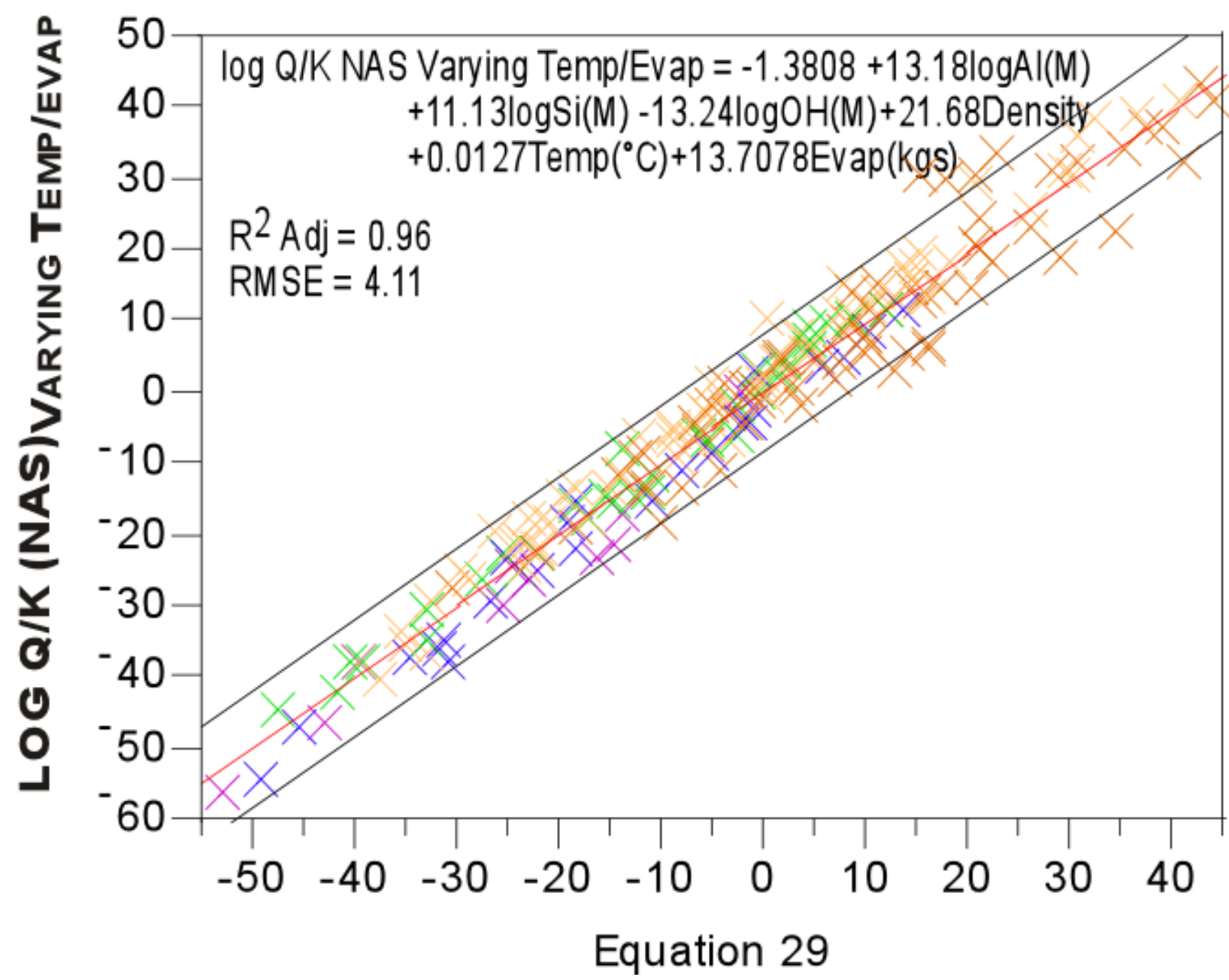

Figure 17. Bivariate Fit of $\log (\mathrm{Q} / \mathrm{K})_{\mathrm{NAS}}$ versus $\log \mathrm{Q}(\mathrm{NAS})_{25^{\circ} \mathrm{C}}$ for the optimized Orthogonal Latin Hypercube model spanning $40^{\circ} \mathrm{C}-180^{\circ} \mathrm{C}$ and $0-80 \%$ evaporation. Note colors are associated with varying $\mathrm{OH}^{-}$concentrations, warmer colors are lower $\mathrm{OH}^{-}$ concentration than cooler colors.

\subsection{The OLH Expanded Evaporator Model}

In order to include the effects of composition, temperature and evaporation (or solution density) into an expanded evaporator model, an OLS regression was performed on a randomly selected subset of the remaining 401 data points in the OLH design to relate $\log [\mathrm{Al}(\mathrm{M})], \log [\mathrm{Si}(\mathrm{M})]$, $\log [\mathrm{OH}(\mathrm{M})]$, evaporator solution density, evaporator operating temperature, and percent evaporation. A uniform random generator was set up in JMP statistical software and rows selected randomly from this column. This provided $200 \mathrm{OLH}$ model data points and $201 \mathrm{OLH}$ validation data points.

A stepwise regression was performed on the 201 randomly selected OLH model data points using the following tank concentrations at ambient temperature as variables, $\log \mathrm{Al}(\mathrm{M}), \log \mathrm{Si}(\mathrm{M}), \log$ 
$\mathrm{OH}(\mathrm{M})$. In addition, evaporator temperature and fraction evaporation in kgs and solution density calculated from ambient tank measurements were used as variables. The OLS generated from the regression of these six variables against the $\log (\mathrm{Q} / \mathrm{K})$ calculated by $\mathrm{GWB}$ yielded Equation 29 with an $\mathrm{R}^{2}=0.96$ and $\mathrm{RMSE}=4.111$ :

$$
-1.3808+13.18 \log [A l(M)]+11.13 \log [\operatorname{Si}(M)]-13.24
$$

Equation $29 \log (Q / K)_{N A S}=\log [O H(M)]+21.68$ Density +0.0127 Temp $\left({ }^{\circ} \mathrm{C}\right)+$

$$
13.7078 \operatorname{Evap}(\mathrm{kgs})
$$

Analysis of the importance (leverage) of each of the factors is shown in Figure 18. It can easily be seen from the leverage plots that the composition effects are more important than the remaining parameters and that the evaporator temperature is the least important of all the effects.
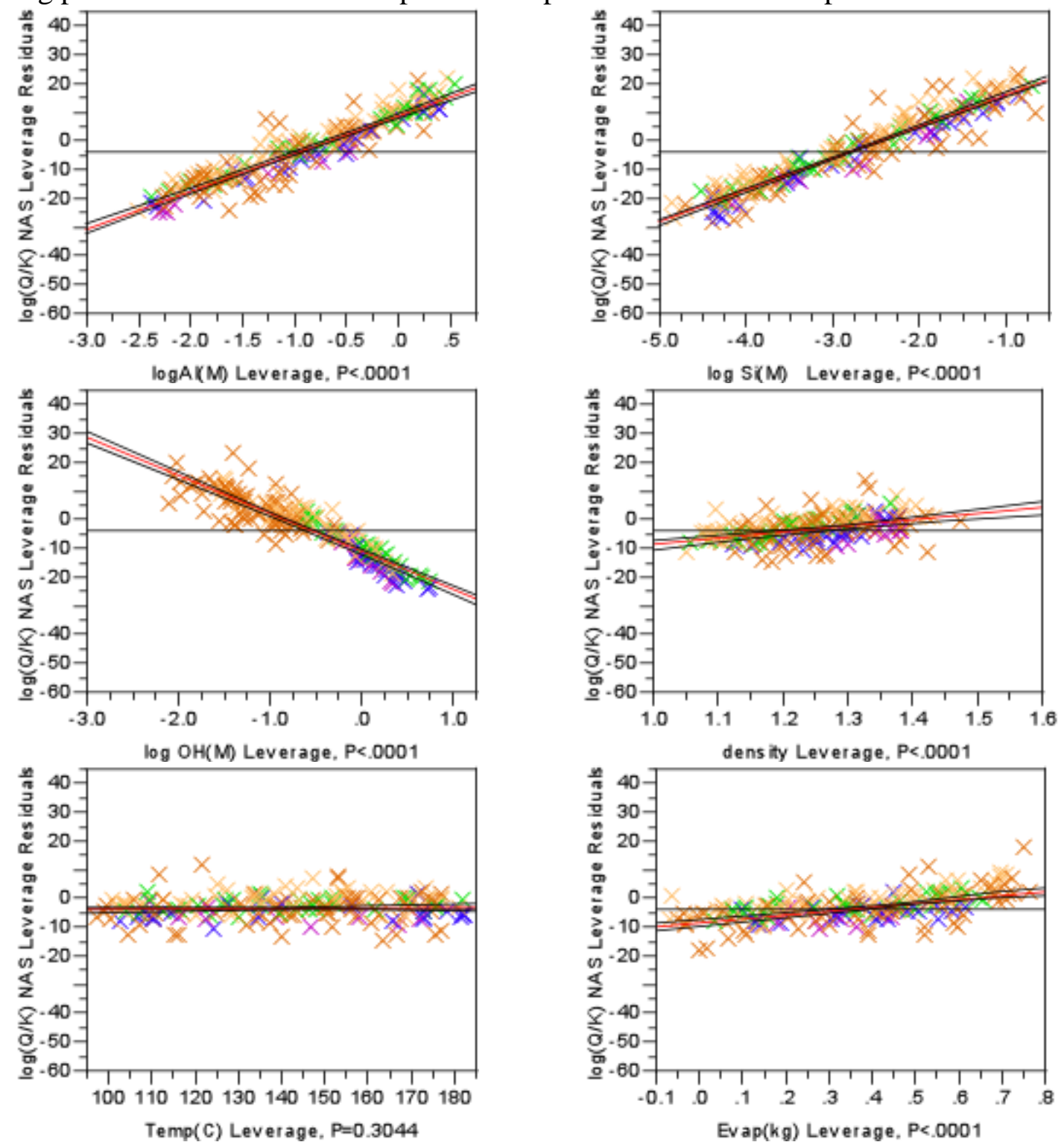

Figure 18 Significance (leverage) of the parameters in Equation 29. 


\section{WSRC-TR-2002-00330, Rev. 0}

Due to strong correlations between $\log \mathrm{Na}(\mathrm{M})$ and density, an alternative equation could be derived using $\log \mathrm{Na}(\mathrm{M})$. However, since this parameter is not routinely measured for evaporator solutions and this measurement is inherently inaccurate at the high molar concentrations of $\mathrm{Na}$ in the evaporator solutions, it is suggested that density not be substituted by $\log \mathrm{Na}(\mathrm{M})$. In addition, there are evaporator temperature effects on solution density, so it is suggested that evaporator operating temperature be kept as a parameter which then allows the density measurement to represent the evaporator operating temperature solution density.

It can then be shown that a model with only five parameters, e.g. $\log \mathrm{Al}(\mathrm{M}), \log \mathrm{Si}(\mathrm{M}), \log$ $\mathrm{OH}(\mathrm{M})$, evaporator operating temperature, and final evaporator solution density, adequately represents the relation between these variables and the $\log (\mathrm{Q} / \mathrm{K})_{\mathrm{NAS}}$ calculated by $\mathrm{GWB}$. A second OLS regression was performed with only five variables (\% evaporation is removed) instead of the six variable used to derive which is shown in Equation 30 with an $R^{2}=0.94$ and RMSE=5.0421.

Equation $30 \quad \log (Q / K)_{N A S}=\begin{aligned} & 9.8691+13.04 \log [\operatorname{Al}(M)]+11.09 \log [\operatorname{Si}(M)]-13.51 \\ & \log [O H(M)]+15.84 \text { Density }+0.0163 \operatorname{Temp}\left({ }^{\circ} \mathrm{C}\right)\end{aligned}$

It should be noted that both Equation 29 and Equation 30 have coefficients for the $\log \mathrm{Al}(\mathrm{M}), \log$ $\mathrm{Si}(\mathrm{M})$, and $\log \mathrm{OH}(\mathrm{M})$ that are close to the parameters 12:12:-12 developed in Equation 13 from the thermodynamic equation governing the precipitation of the $\mathrm{NAS}_{\mathrm{gel}}$.

Either Equation 29 or Equation 30 can be used for SRS evaporator process control. In Equation 29 overheads will have to be monitored to determine the percent evaporation. Use of Equation 30 does not entail monitoring of the percent evaporation since the coefficients of $\log \mathrm{Al}(\mathrm{M}), \log$ $\mathrm{Si}(\mathrm{M}), \log \mathrm{OH}(\mathrm{M})$, density, and operating temperature compensate for the missing parameter because they are all related to percent evaporation. Since Equation 30 is easier to implement than Equation 29, it is recommended that Equation 30 would be easier to implement as the process control model for the SRS $3 \mathrm{H}$ and $2 \mathrm{~F}$ evaporators than Equation 29. However, Figure 19 demonstrates that the residuals span a wider range of $\log (Q / K)_{N A S}$ values, e.g. from +14.90 to 20.45 than the nominal process control model given by Equation 13 and shown in Figure 12 where $\log (Q / K)_{N A S}$ values spanned only \pm 4 . The wider distribution of the residuals for the expanded process control model is due to the expanded range of coverage of all the variables. 
WSRC-TR-2002-00330, Rev. 0

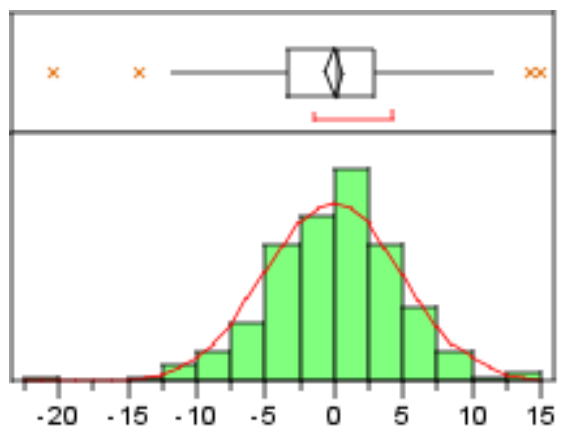

\begin{tabular}{|lrlrr}
\hline Quantiles & \multicolumn{3}{l}{ Moments } \\
\cline { 1 - 4 } $100.0 \%$ & maximum & 14.90 & Mean & -0.000881 \\
$99.5 \%$ & 14.89 & Std Dev & 4.9783151 \\
$97.5 \%$ & 9.84 & Std Err Mean & 0.35202 \\
$90.0 \%$ & & 5.99 & upper 95\% Mean & 0.6932877 \\
$75.0 \%$ & quartile & 2.86 & low er 95\% Mean & -0.695049 \\
$50.0 \%$ & median & 0.24 & $\mathrm{~N}$ & 200 \\
$25.0 \%$ & quartile & -3.38 & & \\
$10.0 \%$ & & -6.06 & & \\
$2.5 \%$ & & -11.08 & & \\
$0.5 \%$ & & -20.42 & & \\
$0.0 \%$ & minimum & -20.45 & & \\
& & &
\end{tabular}

Figure 19. Assessment of the expanded process control model (Equation 30) to the GWB predicted values.

\subsection{Validation of the OLH Expanded Evaporator Model}

A plot of Equation 30, the calculated $\log (\mathrm{Q} / \mathrm{K})_{\mathrm{NAS}}$ from tank parameters to the $\log (\mathrm{Q} / \mathrm{K})_{\mathrm{NAS}}$ calculated by GWB for the 201 OLH model data gave a regression with a zero intercept and a slope of 1.0 (see Equation 31] with an $\mathrm{R}^{2}=0.94$ for the 201 model data points.

Equation $31 \quad \log (Q / K)_{N A S}=0.0009+0.9999($ Equation[31] $)$

When Equation 30 was applied to the remaining 200 OLH validation solutions an OLS regression of the calculated $\log (\mathrm{Q} / \mathrm{K})_{\mathrm{NAS}}$ from tank parameters to the $\log (\mathrm{Q} / \mathrm{K})_{\mathrm{NAS}}$ calculated by GWB an intercept close to zero and a slope of $\sim 1$ was determined as shown in Equation 32.

Equation $32 \quad \log (Q / K)_{N A S}=0.1488+1.0235($ Equation[31])

Equation 32, with an $\mathrm{R}^{2}=0.93$, validates the expanded evaporator model given by Equation 30 . A plot of the residuals for the validation data (similar to the plot shown in Figure 19 for model data) indicates a distribution around $\log (Q / K)_{N A S}$ of zero between +18.28 and -21.45 .

\subsection{Correlation of the OLH Expanded Evaporator Model to Historic Evaporator Operation}

The expanded evaporator process control model (Equation 30) can then be related to recent SRS evaporator operation, in particular the data as measured by SRTC from Table I, Table II, and Table III. The $\log (\mathrm{Q} / \mathrm{K})_{\mathrm{NAS}}$ values calculated from Equation 30 are shown in Table IX for selected data from Table I, Table II, and Table III. The data for all the solutions in Table I, Table II, and Table III is shown in Figure 20. 
WSRC-TR-2002-00330, Rev. 0

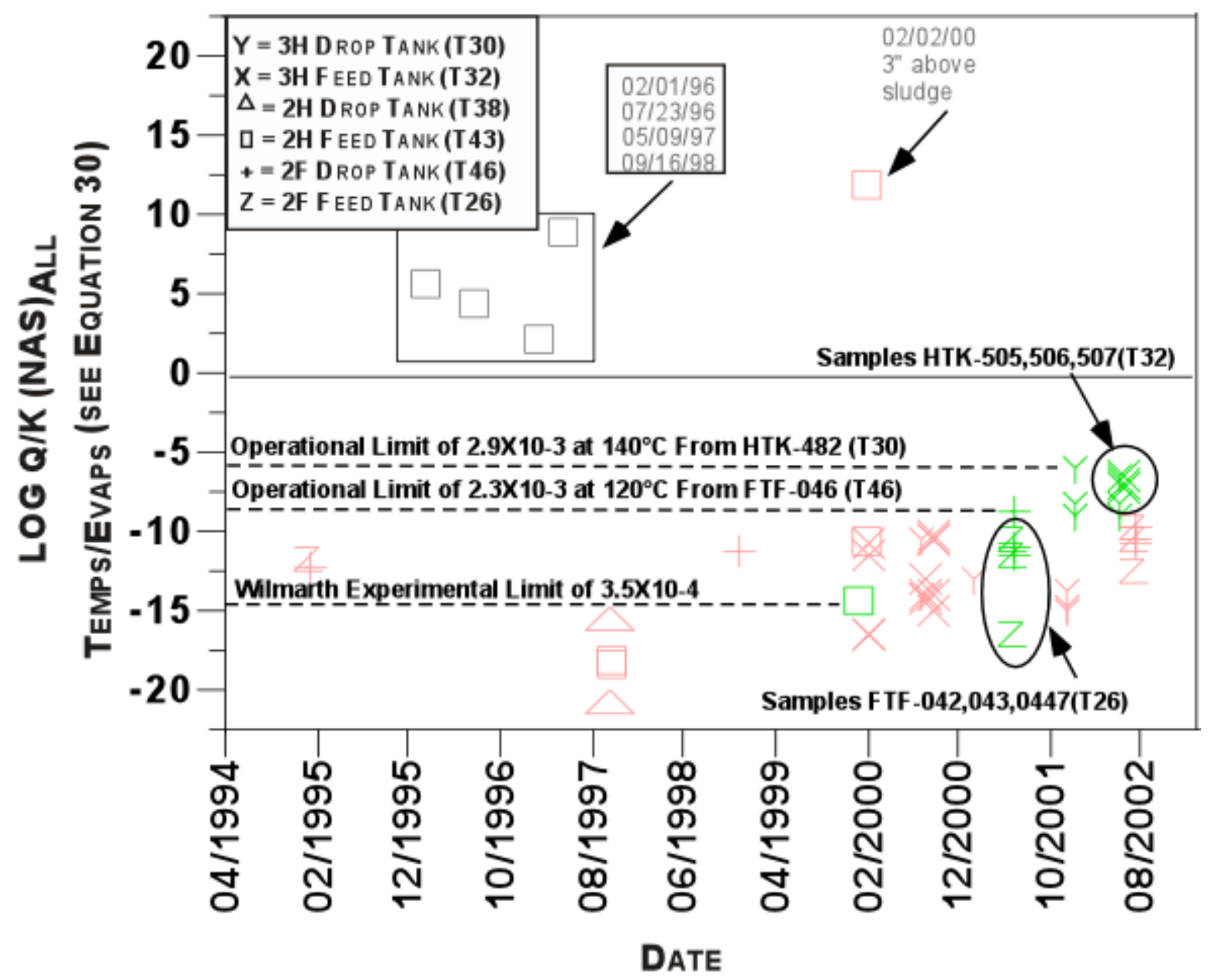

Figure 20. Operational History of SRS Evaporators assessed using Equation 30. 
Table IX. Calculations of $\log (\mathrm{Q} / \mathrm{K})_{\mathrm{NAS}}$ for Selected Samples of Model Data From Equation 30

\begin{tabular}{|c|c|c|c|c|}
\hline Tank/Experiment & Sample & $\begin{array}{l}\text { Height of Sample } \\
\text { in Tank (Inches) }\end{array}$ & $\begin{array}{c}\text { Calculated log } \\
(\mathbf{Q} / \mathrm{K})_{\text {NAS }} \text { from } \\
\text { Equation } 30\end{array}$ & Average \\
\hline Tank $43($ Feed-2H) & $\begin{array}{c}\text { Wilmarth } \\
\text { WSRC-TR- } \\
\text { 2000-00208 }\end{array}$ & Dip & -14.31 & -14.31 \\
\hline Tank 43 (Feed-2H) & $\begin{array}{c}\text { Wilmarth } \\
\text { WSRC-TR- } \\
\text { 2000-00208 }\end{array}$ & $\begin{array}{c}64 \text { (3" above } \\
\text { sludge) }\end{array}$ & +11.92 & +11.92 \\
\hline Tank 46 (Drop 2F) & FTF-045 & 252 & -11.48 & \\
\hline Tank 46 (Drop 2F) & FTF-046 & 199 & -8.50 & \\
\hline Tank 46 (Drop 2F) & FTF-047 & 145 & -10.78 & -10.25 \\
\hline Tank $26($ Feed $2 F)$ & FTF-042 & 261 & -16.29 & \\
\hline Tank $26($ Feed 2F) & FTF-043 & 166 & -10.32 & \\
\hline Tank $26($ Feed 2F) & FTF-044 & 65 & -11.40 & -12.67 \\
\hline Tank $32($ Feed-3H $)$ & HTK-505 & 196.5 & -6.57 & \\
\hline Tank 32 (Feed-3H ) & HTK-506 & 89 & -7.12 & \\
\hline Tank 32 (Feed-3H ) & HTK-507 & 77 & -7.29 & -6.99 \\
\hline Tank 30 (Drop-3H) & HTK-480 & VDS & -8.24 & \\
\hline Tank 30 (Drop-3H) & HTK-481 & VDS & -8.95 & \\
\hline Tank 30 (Drop-3H) & HTK-482 & VDS & -5.78 & -7.66 \\
\hline Tank 30 (Drop-3H) & HTK-508 & 221.9 & -6.35 & \\
\hline Tank 30 (Drop-3H) & HTK-509 & 156 & -8.05 & \\
\hline Tank 30 (Drop-3H) & HTK-511 & 4 & -8.77 & -7.72 \\
\hline
\end{tabular}

Figure 20 demonstrates how the $\log (\mathrm{Q} / \mathrm{K})_{\text {NAS }}$ data for all evaporators at all temperatures and unknown evaporations (calculated using Equation 30), can be related to SRS evaporator operational history between 1995 and 2002. All of the variable depth samples listed in Table IX are highlighted in Figure 20. The expanded process model based on the Mensah et $\mathrm{al}^{8}$ data (Equation 30) can be compared to the solubility product criteria, [Al]*[Si] in $\mathrm{M}^{2} \sim 10^{-4}$, recently used by Wilmarth $^{36,37}$ to determine the acceptability of feed tank solutions for processing in the SRS 3H-Evaporator. The Wilmarth solubility product is shown in Figure 20 compared to recent operational data for Tank 46F and Tank $30 \mathrm{H}$.

Recent Tank 46F samples have been measured by SRTC and this sample can be used to set an operational limit at $\log (\mathrm{Q} / \mathrm{K})_{\mathrm{NAS}}$ of -8.50 since it is based on qualified Si data (sample FTF-046 from the 2F drop tank; see Table IX and Figure 20). More recently, samples from Tank $30 \mathrm{H}$ (sample HTK-482 from the 3H drop tank) analyzed at SRTC and associated with a recent tank 
inspection, indicates that a this sample can be used to set an operational limit at $\log (\mathrm{Q} / \mathrm{K})_{\mathrm{NAS}}=$ 5.78 (see Table IX and Figure 20).

Although these samples are from evaporator drop tanks in the $3 \mathrm{H}$ and $2 \mathrm{~F}$ evaporator systems, the FTF-046 liquor was recycled to the feed tank and experienced an additional evaporation of $31 \%{ }^{54}$. Likewise, the HTK-480, HTK-481, and HTK-482 samples from the SRS 3H evaporator drop tank (Tank 30) were taken on the same day at different depths. The $3 \mathrm{H}$ samples were also recycled to the feed tank and experienced a $9.7 \%$ additional evaporation. ${ }^{54}$ Figure 20 confirms that the HTK-482 series of samples and the FTF-046 series of samples are comfortably below saturation, e.g. $\log (\mathrm{Q} / \mathrm{K})_{\mathrm{NAS}}<<0$. Similarly, the feed tank samples from T26 and T32 (circled in Figure 20) have calculated $\log (\mathrm{Q} / \mathrm{K})_{\mathrm{NAS}}<<0$, e.g. averages of-6.99 and -12.67 , respectively (see Table IX) Therefore, an operation limit of $\log (\mathrm{Q} / \mathrm{K})_{\mathrm{NAS}}<0$ should prohibit aluminosilicate scale formation in SRS evaporators.

Note that the only samples in Figure 20 that have $\log (\mathrm{Q} / \mathrm{K})_{\mathrm{NAS}}>0$ are samples in the gray box that represent the Si enrichment that the SRS 2H Evaporator feed pump was seeing when it was in the Zone of Turbidity between 1996 and 1998, e.g. when the SRS 2H Evaporator was exhibiting copious amounts of aluminosilicate scale. The remaining point at $\log (\mathrm{Q} / \mathrm{K})_{\mathrm{NAS}}>0$ is a sample taken 3" above the sludge at a height of 64"in the $2 \mathrm{H}$ feed tank after the evaporator had been shut down and after feed pump had been moved to a height of 100" so that material had not been processed through the $2 \mathrm{H}$ Evaporator. These data show that precipitation of $\mathrm{NAS}_{\text {gel }}$ historically only occurred during process upset conditions, e.g. when the feed pump for the $2 \mathrm{H}$ evaporator was in the ZOT and the evaporator was receiving frequent silica rich frit SME carryovers from DWPF. $^{3}$

\subsection{Justification for Evaporator Operation at Saturation}

Alternatively, the SRS evaporators could be run at $\log (\mathrm{Q} / \mathrm{K})_{\mathrm{NAS}}=0$ (just saturation) This may be possible since

- $\quad$ silicate solutions can be $>200 \%$ supersaturated at a given elevated temperature and not precipitate until the solutions are cooled. ${ }^{55}$

- $\quad$ precipitation of $\mathrm{NAS}_{\text {gel }}$ historically only occurred during process upset conditions, e.g. when the feed pump for the $2 \mathrm{H}$ evaporator was in the ZOT and the evaporator was receiving frequent silica rich frit SME carryovers from DWPF

The $\log (\mathrm{Q} / \mathrm{K})_{\mathrm{NAS}}=0$ limit on Figure 20 corresponds to a region of 7 years of successful evaporator operation without scaling $\left(\log (\mathrm{Q} / \mathrm{K})_{\text {NAS }}<0\right)$ and evaporator operation with scaling $\left(\log (\mathrm{Q} / \mathrm{K})_{\mathrm{NAS}}>0\right)$. This demonstrates that control at $\log (\mathrm{Q} / \mathrm{K})_{\mathrm{NAS}}=0$ may be possible if samples for analysis are taken at the height of the feed pump and analyzed by an accurate method for $\mathrm{Si}$ unless a process upset, that could cause increased $\mathrm{Si}$, is experienced such as the following:

- $\quad$ evaporator feeds exposed to silica rich frit (SME) carryovers (samples in box shown on Figure 20) 


\section{WSRC-TR-2002-00330, Rev. 0}

- $\quad$ evaporator feeds pumped when the feed pump was too close to the sludge or in the Zone of Turbidity (ZOT) as defined in Parts I and II of this study ${ }^{3,4}$

- $\quad$ evaporator feeds containing high silica and/or zeolite seeds such as the HEME/HEPA digests from DWPF ${ }^{56}$

- $\quad$ sludge wash water that may contain enriched silica from degradation of IE-95 resin which liberates 11 moles of $\mathrm{SiO}_{2}$ for every mole of degraded resin. ${ }^{57}$

This implies that evaporator control at $\log (\mathrm{Q} / \mathrm{K})_{\mathrm{NAS}}=0$ may be acceptable, rather than control at $\log (\mathrm{Q} / \mathrm{K})_{\mathrm{NAS}}<0$, except during process upsets that could bring high concentrations of silica into the evaporator feed or drop tanks.

\subsection{CONCLUSIONS}

Nominal and expanded evaporator process control models are presented in this study based on calculated NAS $_{\text {gel }}$ supersaturations performed using Geochemist's Workbench. Both models are based on solubility data of the NAS gel phase determined by researchers at the University of Southern Australia (Mensah et.al. ${ }^{8}$ ). The kinetic data of Mattigod ${ }^{30}$ is shown to validate the use of the $\mathrm{NAS}_{\text {gel }}$ precursor phase as the basis for the process control modeling. Use of the Mensah ${ }^{8}$ data demonstrated that the previous evaporator process control models had underestimated the importance of the $\mathrm{OH}^{-}$term in modeling.

The nominal process control model covers the last 7 years of SRS evaporator operation over the compositional ranges given in Table VII for a nominal $40 \%$ evaporation at an operating temperature interval of $120-140^{\circ} \mathrm{C}$. The sensitivity of this model to temperature is minimal while the sensitivity to percent evaporation is ten times larger. The revised nominal process control model was derived which takes the form of

$$
\log (Q / K)_{N A S 120-140^{\circ} / 40 \% \text { evap }}=\begin{aligned}
& 37.4848+1.0949(12 \log [A l(M)]+12 \log [\operatorname{Si}(M)] \\
& -12 \log [O H(M)])
\end{aligned}
$$

Where $\log (Q / K)_{N A S 120-140^{\circ} \mathrm{C} / 40 \% \text { evap }}$ on the LHS of the equation is the supersaturation that will be experienced in the evaporator pot between $120-140^{\circ} \mathrm{C}$ after a $40 \%$ evaporation of a solution represented at room temperature by the parameters on the RHS of the equation.

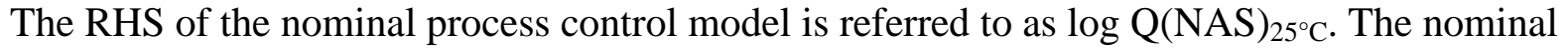
process control model is based on SRS evaporator feed tank data analyzed only at SRTC and is validated using an Orthogonal Latin Hypercube (OLH) statistical design of simulated evaporator solutions. Errors in this model are $\log (\mathrm{Q} / \mathrm{K})_{\mathrm{NAS}}$ of \pm 2 at $90 \%$ confidence (Figure 12).

Equations similar to the nominal process control model can be derived for various combinations of operating temperature and percent evaporation; each should have similar errors in $\log (\mathrm{Q} / \mathrm{K})_{\mathrm{NAS}}$ as the nominal process control model. When these equations are solved at $\log (Q / K)=0$, which

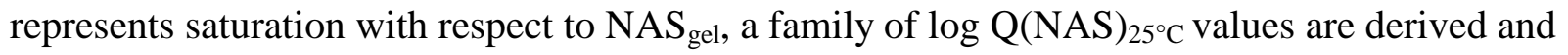


WSRC-TR-2002-00330, Rev. 0

the relationship between the tank chemistry $\left(\log \mathrm{Q}(\mathrm{NAS})_{25^{\circ} \mathrm{C}}\right)$, operating temperature and percent evaporation takes the form

$$
\log \mathrm{Q}(\mathrm{NAS})_{25^{\circ} \mathrm{C}}=-32.1114-0.1119(\% \text { Evaporation })+0.0165\left(\text { Operating Temp }{ }^{\circ} \mathrm{C}\right)
$$

where $\log \mathrm{Q}(\mathrm{NAS})_{25^{\circ} \mathrm{C}}=(12 \log [A l(M)]+12 \log [\operatorname{Si}(M)]-12 \log [O H(M)])$

The coefficients in this equation demonstrate that evaporation and operating temperature have opposite effects. Increased evaporation causes decreased solubility of components while increased temperature causes increased solubility of components. In addition, the coefficients demonstrate that evaporation is a factor of 10 more significant than operating temperature. Due to the insignificance of the temperature term, and the fact that higher temperature causes increased solubility of components, the temperature term can be eliminated from the above equation, which then becomes:

$$
\log \mathrm{Q}(\mathrm{NAS})_{25^{\circ} \mathrm{C}}=-29.9434-0.1092(\% \text { Evaporation })
$$

The above relation between $\log \mathrm{Q}(\mathrm{NAS}){ }_{25^{\circ} \mathrm{C}}$ and percent evaporation can be used to control scaling in the SRS evaporators at a variety of temperatures if the percent evaporation can be monitored. However, this process control approach is only valid over the compositional range of solutions modeled, e.g. the historic composition range experienced between 1995 and 2002 (Table VII).

The expanded evaporator process control model covers the wider tank farm compositional region given in Table VIII over evaporator operating conditions of:

- $0-80$ wt \% evaporation

- $100^{\circ} \mathrm{C}$ to $180^{\circ} \mathrm{C}$

- wider composition ranges defined in Table VIII

The expanded process control model was developed using an OLH experimental design covering the composition region defined over a 28 year operational period of the tank farm (1973-2001). Half of the data points, randomly chosen, were used to develop the expanded process control model and the remaining half were used for validation. The expanded process control model takes the form

$$
\log (Q / K)_{N A S}=\begin{aligned}
& 9.8691+13.04 \log [\operatorname{Al}(M)]+11.09 \log [\operatorname{Si}(M)]-13.51 \\
& \log [O H(M)]+15.84 \text { Density }+0.0163 \operatorname{Temp}\left({ }^{\circ} \mathrm{C}\right)
\end{aligned}
$$

The usage of the expanded process control model does not entail monitoring of the percent evaporation since the coefficients of $\log \mathrm{Al}(\mathrm{M}), \log \mathrm{Si}(\mathrm{M}), \log \mathrm{OH}(\mathrm{M})$, density, and operating temperature compensate for the missing parameter because they are all related to percent evaporation. However, the errors in this model are $\log (\mathrm{Q} / \mathrm{K})_{\mathrm{NAS}}$ of \pm 6 at $90 \%$ confidence (Figure 19). 


\section{WSRC-TR-2002-00330, Rev. 0}

It should be noted that the nominal process control model uses coefficients for the $\log \mathrm{Al}(\mathrm{M}), \log$ $\mathrm{Si}(\mathrm{M})$, and $\log \mathrm{OH}(\mathrm{M})$ that are the parameters 12:12:-12 developed from the thermodynamic equation governing the phase boundary between $\mathrm{NAS}_{\text {gel }}$ and $\mathrm{AlOOH}$ which in turn is governed by the stoichiometry of the $\mathrm{NAS}_{\text {gel: }}$ :

$$
12 \mathrm{Al}(\mathrm{OH})_{4}^{-}+12 \mathrm{SiO}_{2}(\mathrm{aq})+12 \mathrm{NaOH}+3 \mathrm{H}_{2} \mathrm{O} \Leftrightarrow \mathrm{Na}_{12} \mathrm{Al}_{12} \mathrm{Si}_{12} \mathrm{O}_{48} \bullet 27 \mathrm{H}_{2} \mathrm{O}+12 \mathrm{OH}^{-}
$$

The and the expanded process control model uses coefficients that are similar to those governed by the stoichiometry of the $\mathrm{NAS}_{\mathrm{gel}}$.

When the expanded process control model is related to the past 7 years of SRS evaporator operating history it demonstrates that normal operation has been at $\log (\mathrm{Q} / \mathrm{K})_{\mathrm{NAS}}<<0$ undersaturated region, e.g. values in the -15 to -10 range for the $2 \mathrm{H}$ evaporator when it was not scaling, for the $2 \mathrm{~F}$ and $3 \mathrm{H}$ evaporators and in the -7 to -5 range for recent $3 \mathrm{H}$ evaporator operation (Table IX).

Therefore, a $\log (\mathrm{Q} / \mathrm{K})_{\mathrm{NAS}}<0$ process control limit can be set for implementation of either the nominal or the expanded process control model based on operational history or a process control limit of $\log (\mathrm{Q} / \mathrm{K})_{\mathrm{NAS}}=0$ can be implemented except during process upset conditions. The limit of $\log (\mathrm{Q} / \mathrm{K})_{\mathrm{NAS}}=0$ separates the 7 years (1995-2002) of SRS Evaporator operation modeled into two populations, referred to as "normal operation" and "process upset operation." This allows the simplified nominal process control model relating $\mathrm{NAS}_{\text {gel }}$ supersaturation to chemistry and percent evaporation, e.g. $\log \mathrm{Q}(\mathrm{NAS})_{25^{\circ} \mathrm{C}}=-29.9434-0.1092$ (\%Evaporation), to be implemented.

Operation "just at saturation" is an attractive approach because of the following:

- $\quad$ silicate solutions can be $>200 \%$ supersaturated at a given elevated temperature and not precipitate until the solutions are cooled

- $\quad$ precipitation of $\mathrm{NAS}_{\text {gel }}$ historically only occurred during process upset conditions, e.g. when the feed pump for the $2 \mathrm{H}$ evaporator was in the Zone of Turbidity (ZOT) and the evaporator was receiving frequent silica rich frit SME carryovers from DWPF

This demonstrates that it is only necessary to control at $\log (\mathrm{Q} / \mathrm{K})_{\mathrm{NAS}}<0$ if there are known process upsets that could cause increased $\mathrm{Si}$ such as the following:

- $\quad$ evaporator feeds exposed to silica rich frit (SME) carryovers (samples in box shown on Figure 20)

- $\quad$ evaporator feeds pumped when the feed pump was too close to the sludge or in the Zone of Turbidity (ZOT) as defined in Parts I and II of this study 
WSRC-TR-2002-00330, Rev. 0

- $\quad$ evaporator feeds containing high silica and/or zeolite seeds such as the HEME/HEPA digests from DWPF

- $\quad$ sludge wash water that may contain enriched silica from degradation of IE-95 resin which liberates 11 moles of $\mathrm{SiO}_{2}$ for every mole of degraded resin

Control at $\log (\mathrm{Q} / \mathrm{K})_{\mathrm{NAS}}=0$ allows credit to be taken for keeping the feed pumps 40 " above the sludge or 20"above the ZOT, so that receipt of silica rich material from the ZOT cannot occur. 
WSRC-TR-2002-00330, Rev. 0

\subsection{ACKNOWLEDGEMENTS}

Kent Gilbreath from the SRS H-Area Tank farm is thanked for providing the data about sludge levels, feed pump levels, and operating temperatures of the SRS 3H from the Tank Farm morning reports. Ken Jones of the F-Area laboratory is acknowledged for discussions about the F-Area Si analytic methodology and dilution factors.

Thomas B. Caldwell is also especially thanked for the database that he provided with $>1800$ datapoints spanning 29 years of operating history in the tank farm that related tank composition to density. This data is shown in Appendix A and was of great assistance in converting the molar to molal compositions by developing a solution density correlation.

Many thanks are due to David Hobbs and Bill Wilmarth of SRTC for their frequent and always helpful counsel. Kevin G. Brown, formerly of SRTC, is also thanked for his encouragement and help in setting up computer interfaces between the GWB, Excel, and JMP softwares to eliminate human error when transferring database calculations between the different software packages.

This work was performed under contract No. DE-AC09-96SR18500 with the Department of Energy and co-funded by the Tank Focus Area under Technical Task Plan \# SR-1-9-WT-31. 
WSRC-TR-2002-00330, Rev. 0

\section{APPENDIX A}

\section{DENSITY CORRELATION}

\section{$\underline{\text { Summary }}$}

Tank compositions and analytical results are typically reported on a solution basis (e.g., mg/L solution). For input into the Geochemist's Workbench (GWB), molality (moles per kilogram of solvent) is used. To convert from a solution based concentration to a solvent based concentration, the solution density must either be measured or estimated. Using historical solution density data from Tank Farm analyses, a correlation to relate density to sodium content was developed. The correlation is:

$$
\begin{aligned}
& \text { For } \mathrm{Na}(\mathrm{M}) \leq 16.5, \\
& \qquad \text { density }=1.013+5.701 \cdot 10^{-2} \cdot \mathrm{Na}(\mathrm{M})-1.725 \cdot 10^{-3} \cdot \mathrm{Na}(\mathrm{M})^{2} \\
& \text { Else } \quad \text { density }=1.483
\end{aligned}
$$

This correlation is based on data measured at ambient temperature (nominally $25^{\circ} \mathrm{C}$ ). This correlation is used to convert from molarity to molality for all compositions input into GWB for evaporator modelling.

\section{Correlation Derivation}

A relationship to calculate tank salt solution density from solution composition was developed using past waste tank analyses. T. B. Caldwell of High Level Waste Division Program Management compiled a table of historic tank analyses with measured densities (see Table A-1). In Table A-1, the sodium concentration is calculated from a charge balance rather than a direct measurement. All other values in the table were measured. This table was imported into the statistical software JMP ${ }^{\circledR}$. Samples with sodium concentrations less than $0.05 \mathrm{M}$ were deleted. These few points had unrealistically high measured densities. Other than deleting these points, there was no other screening of the data. As can be seen from Figure A-1, there are some obvious points with few potentially bad data have little impact on the correlation.

The Fit $\mathrm{Y}$ by $\mathrm{X}$ function of JMP was then used to fit a curve of density as a function of sodium concentration. A second order polynomial fit was chosen. This choice gave a good balance between simplicity and representation of the data. The results of the curve fit are given in Figure A-1.

$1 \quad$ JMP $^{\circledR}$ Version 4.0.5, SAS Institute Inc., SAS Campus Drive, Cary, North Carolina 27513 
WSRC-TR-2002-00330, Rev. 0

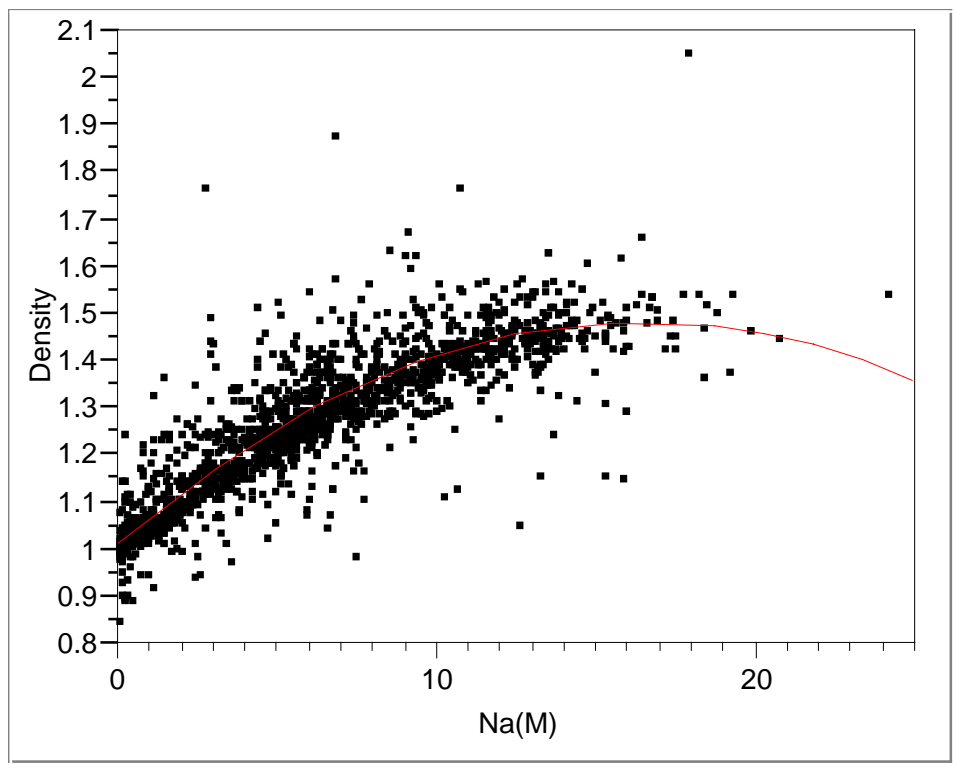

Polynomial Fit Degree=2

Density $=1.0713231+0.0369386 \mathrm{Na}(\mathrm{M})-0.0017254(\mathrm{Na}(\mathrm{M})-5.81717)^{\wedge} 2$

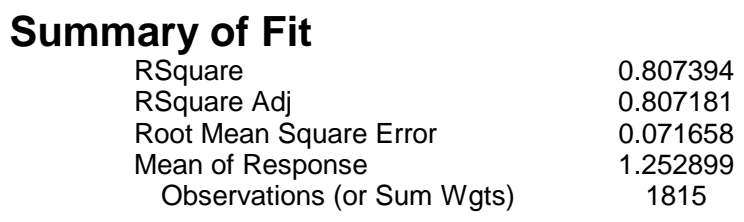

Figure A-4. Polynomial fit of Tank Solution Density to Sodium Molarity

The correlation given in Figure A-1, when expanded, yields:

$$
\text { density }=1.013+5.701 \cdot 10^{-2} \cdot N a(M)-1.725 \cdot 10^{-3} \cdot N a(M)^{2}
$$

Taking the derivative of the above equation, setting to zero, and solving for $\mathrm{Na}(\mathrm{M})$, the maximum predicted density (1.483) occurs at a sodium concentration of $16.5 \mathrm{M}$. Because a positively sloped regression of densities at sodium concentrations grater than $16.5 \mathrm{M}$ was not found, the predicted density is set to 1.483 for these high sodium concentrations. This modified density correlation is shown graphically in Figure A-2.

By setting the density of salt solutions with $\mathrm{Na}(\mathrm{M})>16.5$ to 1.483 , higher concentration solution densities will undoubtedly be underestimated. In normal evaporator operations, salt solutions are concentrated to a density of approximately 1.6, implying that evaporator feeds would have densities less than 1.6. Therefore, by setting the maximum density in the correlation to 1.483 , the worst case underestimation of density would still be less than $10 \%$. 
WSRC-TR-2002-00330, Rev. 0

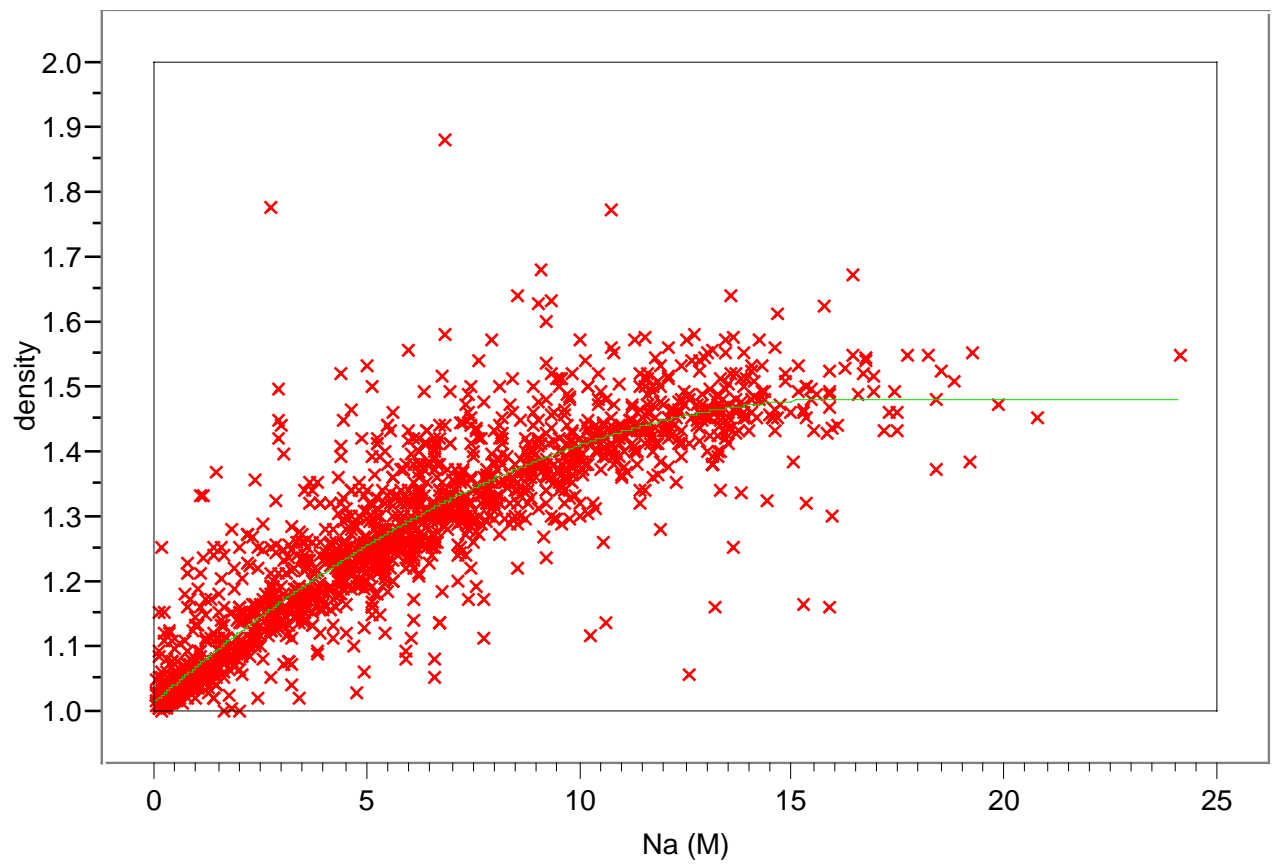

Figure A-5. Comparison Between Measured (X) and Predicted (-) Denisty

Figure A-3 shows the absolute value of the percent difference between the predicted and measured densities. It should be noted that the difference between the predicted and measured densities was less than $10 \%$ in over $90 \%$ of the samples. 
WSRC-TR-2002-00330, Rev. 0

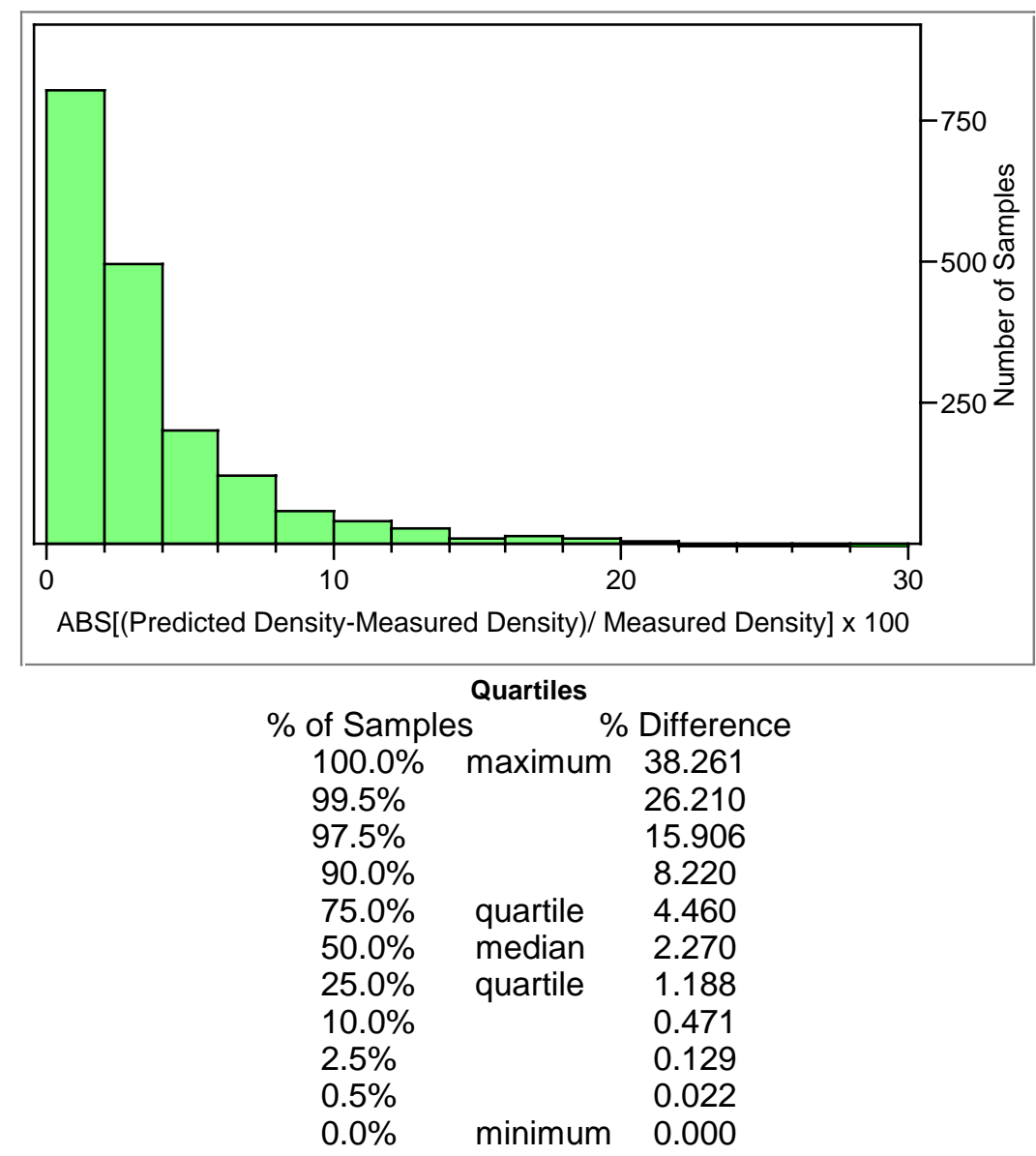

Figure A-6. Histogram Showing the Percent Difference Between Predicted and Measured Densities 
WSRC-TR-2002-00330, Rev. 0

Table A-2. Measured Tank Solution Densities and Chemical Compositions

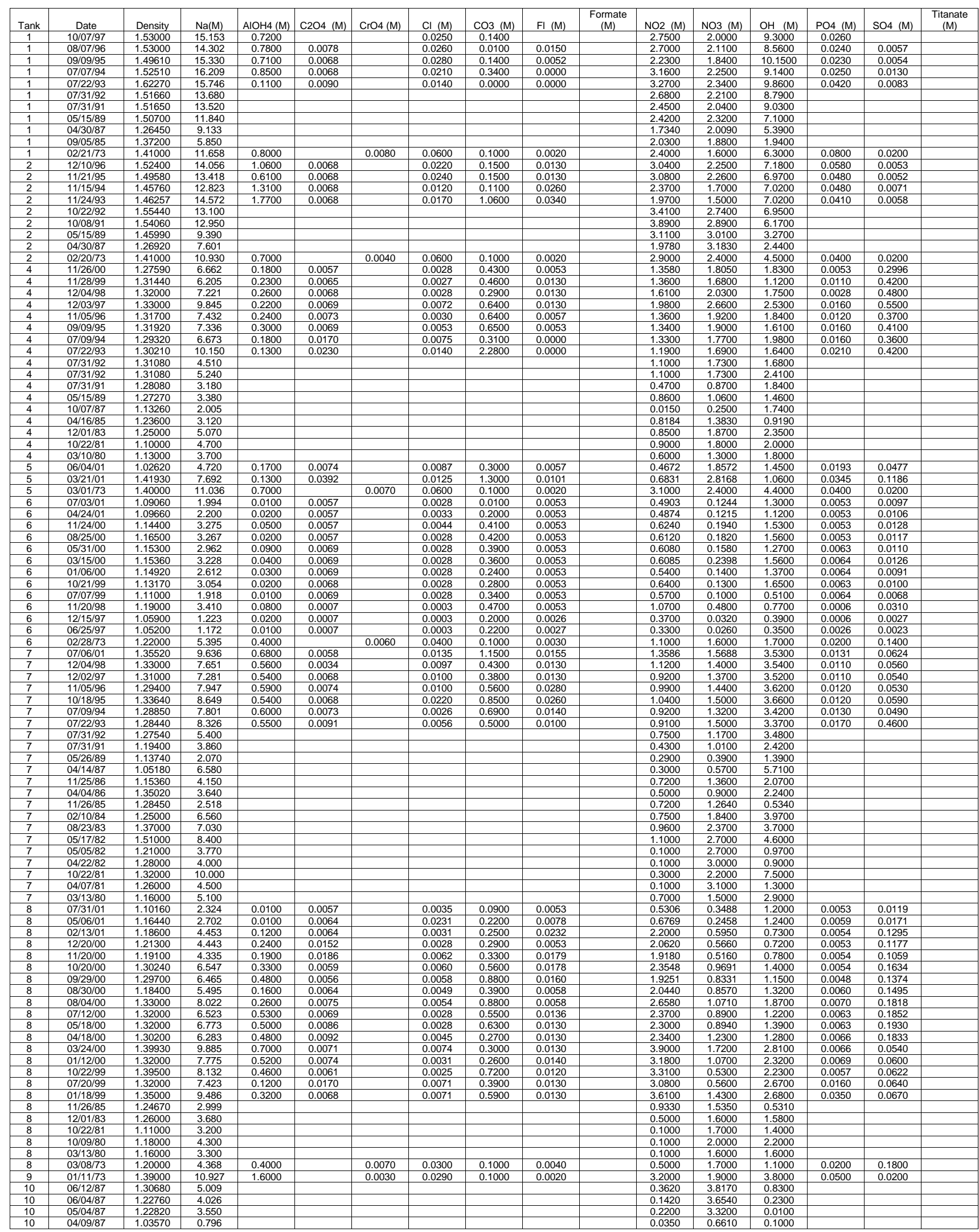


WSRC-TR-2002-00330, Rev. 0

\begin{tabular}{|c|c|c|c|c|}
\hline Tank & $\begin{array}{c}\text { Date } \\
\end{array}$ & Density & $\frac{\mathrm{Na}(\mathrm{M})}{1.520}$ & $\mathrm{AlOH} 4(\mathrm{M})$ \\
\hline$\frac{10}{10}$ & \begin{tabular}{|l|}
$04 / 07 / 87$ \\
$04 / 25 / 86$
\end{tabular} & $\begin{array}{l}1.17630 \\
1.06020\end{array}$ & $\begin{array}{l}1.520 \\
0.740\end{array}$ & \\
\hline 10 & $12 / 20 / 85$ & 1.35550 & 2.377 & \\
\hline$\frac{10}{10}$ & $\begin{array}{l}11 / 26 / 85 \\
07 / 199 / 85\end{array}$ & $\begin{array}{l}1.41000 \\
1.37000\end{array}$ & $\begin{array}{l}7.440 \\
6590\end{array}$ & \\
\hline 10 & $02 / 28 / 85$ & 1.43000 & $\begin{array}{l}0.590 \\
7.993\end{array}$ & \\
\hline 10 & $09 / 14 / 84$ & 1.41000 & 5.220 & \\
\hline 10 & $09 / 14 / 84$ & 1.41000 & 5.230 & \\
\hline 10 & $05 / 21 / 83$ & 1.41000 & 6.910 & \\
\hline$\frac{10}{10}$ & $\begin{array}{l}03 / 26 / 83 \\
03 / 26 / 83\end{array}$ & $\begin{array}{l}1.41000 \\
1.33000\end{array}$ & $\frac{6.560}{4.910}$ & \\
\hline 10 & $03 / 01 / 83$ & $\begin{array}{l}1.03000 \\
.43000\end{array}$ & $\begin{array}{l}.9910 \\
5.550\end{array}$ & \\
\hline 10 & $12 / 14 / 82$ & 1.39000 & 5.100 & \\
\hline 10 & $10 / 07 / 82$ & $\begin{array}{l}1.42000 \\
\end{array}$ & 6.100 & \\
\hline 10 & $\begin{array}{l}09 / 30 / 82 \\
09 / 23 / 81\end{array}$ & $\begin{array}{l}1.20000 \\
1.2600\end{array}$ & $\begin{array}{r}4.800 \\
4800\end{array}$ & \\
\hline$\frac{10}{10}$ & $\begin{array}{l}09 / 23 / 81 \\
09 / 22 / 81\end{array}$ & $\begin{array}{l}1.26000 \\
1.18000\end{array}$ & $\frac{4.800}{2.700}$ & \\
\hline 10 & $\begin{array}{l}09 / 22 / 81 \\
01 / 13 / 81 \\
\end{array}$ & $\begin{array}{l}1.18000 \\
.09000 \\
\end{array}$ & $\begin{array}{l}. .1500 \\
1.500\end{array}$ & \\
\hline 10 & $12 / 19 / 80$ & 1.13000 & 1.580 & \\
\hline 10 & $06 / 10 / 80$ & 1.02000 & 0.500 & \\
\hline$\frac{10}{10}$ & $\begin{array}{l}05 / 19 / 80 \\
04 / 28 / 80\end{array}$ & $\begin{array}{l}1.02000 \\
1.02000\end{array}$ & $\frac{1.400}{2400}$ & \\
\hline$\frac{10}{10}$ & $\begin{array}{l}04 / 288 / 80 \\
04 / 28 / 80\end{array}$ & $\begin{array}{l}1.02000 \\
1.02000\end{array}$ & $\begin{array}{l}2.400 \\
1.400\end{array}$ & \\
\hline 10 & $04 / 04 / 80$ & 1.18000 & 5.200 & \\
\hline 10 & $03 / 24 / 80$ & 1.32000 & 6.250 & \\
\hline 10 & $01 / 18 / 80$ & $\begin{array}{l}1.20000 \\
1.8000\end{array}$ & $\begin{array}{l}2.800 \\
7060\end{array}$ & \\
\hline$\frac{10}{10}$ & $\begin{array}{r}08 / 29 / 79 \\
08 / 27 / 74\end{array}$ & $\begin{array}{l}1.38000 \\
1.39000\end{array}$ & $\begin{array}{l}7.960 \\
9.647\end{array}$ & $\frac{0.1000}{10000}$ \\
\hline 11 & $085 / 22 / 100$ & $\begin{array}{l}1.39000 \\
1.42000\end{array}$ & $\begin{array}{l}9.641 \\
8.705\end{array}$ & 0.3000 \\
\hline 11 & $05 / 29 / 99$ & 1.38000 & 8.780 & 0.2000 \\
\hline $\begin{array}{l}11 \\
11\end{array}$ & $06 / 13 / 98$ & $\begin{array}{l}1.38000 \\
138400\end{array}$ & $\begin{array}{l}8.439 \\
7952\end{array}$ & $\begin{array}{l}0.2800 \\
03800\end{array}$ \\
\hline 11 & 05/09/97 & $\begin{array}{r}1.38400 \\
13630\end{array}$ & $\begin{array}{l}7.952 \\
7.9158\end{array}$ & 0.3800 \\
\hline$\frac{11}{11}$ & $\begin{array}{l}05 / 08 / 96 \\
03 / 27 / 95\end{array}$ & $\begin{array}{l}1.36300 \\
1.336\end{array}$ & $\begin{array}{l}7.158 \\
9.171\end{array}$ & $\begin{array}{l}0.1600 \\
0.2600\end{array}$ \\
\hline 11 & $\begin{array}{l}03 / 27 / 95 \\
03 / 24 / 94\end{array}$ & $\begin{array}{l}1.33660 \\
1.28700\end{array}$ & $\begin{array}{l}9.1 / 1 \\
8.536\end{array}$ & $\begin{array}{l}0.2600 \\
0.6200\end{array}$ \\
\hline 11 & $03 / 03 / 93$ & 1.32240 & 7.717 & 0.3000 \\
\hline 11 & $02 / 17 / 92$ & 1.29080 & 6.480 & \\
\hline 11 & $02 / 25 / 91$ & 1.28560 & 9.540 & \\
\hline 11 & $03 / 08 / 90$ & 1.20850 & 4.970 & \\
\hline 11 & 03/20/89 & 1.08790 & $\begin{array}{l}2.070 \\
4184\end{array}$ & \\
\hline 11 & $\begin{array}{l}03 / 7 / 888 \\
06198 / 8\end{array}$ & $\begin{array}{l}1.28000 \\
1.23200\end{array}$ & $\begin{array}{l}\frac{4.184}{3.989} \\
\end{array}$ & \\
\hline 11 & $00 / 9 / 866$ & 1.232000 & 7.530 & \\
\hline 11 & $10 / 10 / 82$ & 1.36000 & 5.600 & \\
\hline 11 & $01 / 21 / 82$ & 1.38000 & 6.100 & \\
\hline 11 & $07 / 15 / 81$ & 1.28000 & 5.500 & \\
\hline 11 & $06 / 24 / 80$ & 1.23000 & 4.800 & \\
\hline 11 & $04 / 01 / 80$ & 1.12000 & & \\
\hline 11 & 06/0/101 & 1.46350 & 9.604 & 0.2300 \\
\hline 12 & $11 / 29 / 84$ & 1.36800 & 1.411 & \\
\hline 12 & $09 / 10 / 81$ & 1.44000 & 6.700 & \\
\hline 12 & $04 / 01 / 80$ & 1.20000 & 5.600 & \\
\hline 13 & 08/24/01 & 1.46310 & 4.623 & 0.1000 \\
\hline 13 & 08/25/01 & 1.38160 & 19.193 & 1.0100 \\
\hline$\frac{13}{12}$ & 09010900 & $\begin{array}{l}1.44700 \\
.4250\end{array}$ & $\begin{array}{l}11.231 \\
11.90\end{array}$ & 0.1600 \\
\hline 13 & 10.0709 & 1.405000 & 10.477 & 0.0400 \\
\hline 13 & - $04 / 15 / 99$ & 1.40000 & 10.608 & 0.4800 \\
\hline 13 & $10 / 18 / 98$ & 1.36000 & 10.953 & 0.7200 \\
\hline 13 & 09/24/97 & 1.40000 & 13.299 & 0.6800 \\
\hline 13 & $09 / 19 / 96$ & 1.43000 & 10.341 & 0.4500 \\
\hline 13 & $10 / 01 / 95$ & 1.45000 & 10.706 & 0.6700 \\
\hline 13 & $09 / 29 / 94$ & 1.41100 & $\begin{array}{ll}11.498 \\
\end{array}$ & 0.6100 \\
\hline 13 & $09 / 05 / 93$ & 1.38220 & 11.916 & 0.6800 \\
\hline 13 & $04 / 30 / 93$ & 1.41380 & $\begin{array}{l}12.823 \\
14500\end{array}$ & 0.6700 \\
\hline 13 & $\begin{array}{l}11 / 30 / 92 \\
\end{array}$ & $\begin{array}{l}1.45048 \\
15124\end{array}$ & $\begin{array}{l}14.500 \\
12070\end{array}$ & $\begin{array}{l}0.5400 \\
07500\end{array}$ \\
\hline $\begin{array}{l}13 \\
13\end{array}$ & $\begin{array}{l}05 / 29 / 91 \\
02 / 25 / 91\end{array}$ & $\begin{array}{l}\frac{1.51240}{1.43100} \\
\end{array}$ & $\frac{12.070}{11.650}$ & 0.7500 \\
\hline 13 & $03 / 09 / 90$ & 1.43490 & 10.780 & \\
\hline 13 & $03 / 20 / 89$ & 1.43040 & 7.560 & \\
\hline 13 & $\begin{array}{c}03 / 21 / 88 \\
\end{array}$ & $\begin{array}{l}1.39880 \\
.2050\end{array}$ & 8.723 & \\
\hline$\frac{13}{13}$ & $\begin{array}{r}09 / 28 / 87 \\
12 / 2 / 18\end{array}$ & $\begin{array}{l}1.23590 \\
13\end{array}$ & $\begin{array}{l}9.220 \\
8560\end{array}$ & \\
\hline$\frac{13}{13}$ & $\begin{array}{l}12 / 12186 \\
04 / 21 / 86\end{array}$ & $\begin{array}{l}1.30000 \\
1.28940\end{array}$ & $\begin{array}{l}8.560 \\
6.655 \\
\end{array}$ & \\
\hline 13 & $05 / 01 / 85$ & 1.42000 & 2.930 & \\
\hline 13 & 05/02/84 & 1.44800 & 2.930 & \\
\hline 13 & $\begin{array}{r}08 / 05 / 83 \\
0715 / 182\end{array}$ & $\begin{array}{l}1.15800 \\
111500\end{array}$ & $\begin{array}{l}15.870 \\
13200\end{array}$ & \\
\hline 13 & $\begin{array}{l}07 / 15 / 82 \\
08 / 30 / 81\end{array}$ & $\begin{array}{l}1.16000 \\
1.50000\end{array}$ & $\frac{13.200}{10.200}$ & \\
\hline 13 & $06 / 29 / 81$ & $\begin{array}{l}1.50000 \\
1.48000\end{array}$ & $\frac{0.200}{9.740}$ & \\
\hline 13 & $06 / 29 / 81$ & 1.5 & 8.9 & \\
\hline 13 & $04 / 12 / 81$ & 1.41000 & 9.700 & \\
\hline 13 & $\begin{array}{l}02 / 25 / 81 \\
11 / 19 / 80\end{array}$ & $\begin{array}{l}1.42000 \\
1.5200\end{array}$ & $\begin{array}{l}4.840 \\
9.8000\end{array}$ & \\
\hline $\begin{array}{l}13 \\
13\end{array}$ & $\begin{array}{l}111 / 19980 \\
02 / 20 / 80\end{array}$ & $\begin{array}{l}1.52000 \\
1.44000\end{array}$ & $\begin{array}{l}9.800 \\
8.900\end{array}$ & \\
\hline 13 & $02 / 20 / 80$ & 1.50000 & 9.5 & \\
\hline 13 & $01 / 29 / 80$ & 1.5 & 11.5 & \\
\hline 13 & $01 / 26 / 80$ & $\begin{array}{l}1.30000 \\
1.2000\end{array}$ & 10.010 & \\
\hline 13 & $\begin{array}{r}01 / 18 / 80 \\
08 / 20 / 70\end{array}$ & $\begin{array}{l}1.42000 \\
1.41000\end{array}$ & $\frac{11.670}{10.210}$ & \\
\hline & $04 / 27 / 79$ & 1.410000 & $\frac{10.210}{10.620}$ & \\
\hline 14 & $10 / 0$ & 1.77000 & 10700 & \\
\hline 14 & 04 & 1.2 & & \\
\hline & & & 8.7 & 1.1000 \\
\hline 15 & $03 / 07 / 88$ & 1.26600 & 2.3 & \\
\hline 15 & $12 / 01 / 87$ & 1.23000 & 3.0 & \\
\hline 15 & $09 / 0$ & 1.17000 & 3.3 & 0.0800 \\
\hline 15 & 121 & 1.10500 & 0.395 & \\
\hline 15 & 12213 & 1.10 & 1.996 & \\
\hline$\frac{15}{15}$ & $09 / 2$ & 1.14700 & $\begin{array}{l}5.309 \\
520\end{array}$ & \\
\hline 15 & 09/1/1/81 & 1.24000 & 3500 & \\
\hline 15 & $09 / 2$ & 106 & 07 & \\
\hline 15 & & & & \\
\hline 17 & & & 0.751 & 0.0200 \\
\hline $\begin{array}{l}17 \\
\end{array}$ & $07 / 01 / 96$ & 1.04200 & 0.936 & 0.0 \\
\hline 17 & $11 / 21 / 95$ & 1.03930 & 0.719 & 0.0100 \\
\hline 17 & $08 / 18 / 95$ & 1.03013 & 0.900 & 0.0200 \\
\hline
\end{tabular}


WSRC-TR-2002-00330, Rev. 0

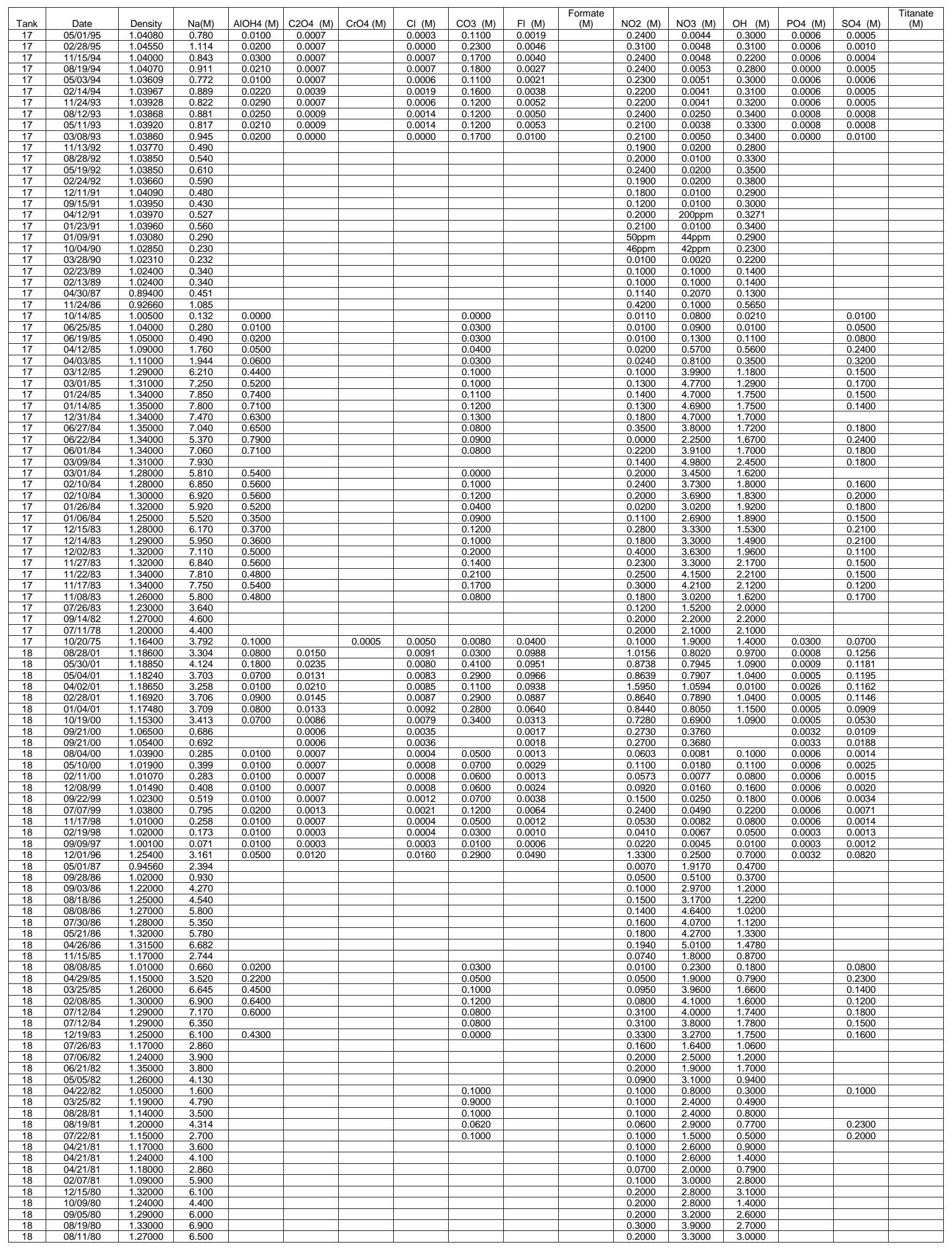


WSRC-TR-2002-00330, Rev. 0

\begin{tabular}{|c|c|c|c|c|c|}
\hline Tank & Date & Density & $\mathrm{Na}(\mathrm{M})$ & AlOH4 (M & $\mathrm{C} 204(\mathrm{M})$ \\
\hline 18 & $\begin{array}{c}07 / 25 / 80 \\
\end{array}$ & $\begin{array}{l}\text { Detsyy } \\
1.33000\end{array}$ & 5.500 & & \\
\hline 18 & $07 / 10 / 80$ & 1.27000 & 6.600 & & \\
\hline 18 & $06 / 24 / 80$ & 1.36000 & 9.300 & & \\
\hline $\begin{array}{l}18 \\
19\end{array}$ & $\begin{array}{l}10 / 14 / 75 \\
00 / 724 / 01\end{array}$ & $\begin{array}{l}1.36400 \\
1.18360\end{array}$ & $\begin{array}{l}10.061 \\
3.420\end{array}$ & $\begin{array}{l}0.7000 \\
0.0700\end{array}$ & \\
\hline $\begin{array}{l}19 \\
19\end{array}$ & $\begin{array}{l}07 / 24 / 01 \\
06 / 27 / 01\end{array}$ & $\begin{array}{l}1.1 .18360 \\
1.8450\end{array}$ & $\begin{array}{l}3.420 \\
3771\end{array}$ & $\frac{0.0700}{0.1100}$ & \begin{tabular}{|l|}
0.0145 \\
0.0154
\end{tabular} \\
\hline 19 & $02 / 28 / 01$ & 1.16920 & 3.706 & 0.0900 & 0.0145 \\
\hline 19 & $02 / 01 / 01$ & 1.17900 & 3.676 & 0.1000 & 0.0153 \\
\hline 19 & $01 / 01 / 01$ & 1.17900 & 3.676 & 0.1000 & 0.0153 \\
\hline 19 & $12 / 05 / 00$ & 1.17100 & 3.402 & 0.0700 & \\
\hline 19 & $10 / 31 / 00$ & 1.21990 & 4.785 & 0.1200 & 0.0130 \\
\hline 19 & $10 / 02 / 100$ & 1.28600 & 7.093 & 0.1500 & 0.0052 \\
\hline 19 & $09 / 15 / 00$ & 1.28200 & 6.069 & 0.0100 & 0.0057 \\
\hline 19 & $\begin{array}{l}08 / 23 / 00 \\
\end{array}$ & $\begin{array}{l}1.28800 \\
125520\end{array}$ & $\begin{array}{l}7.360 \\
5026\end{array}$ & 0.0900 & 0.0059 \\
\hline 19 & 03/21/00 & $\begin{array}{l}1.25520 \\
102500\end{array}$ & $\begin{array}{l}5.236 \\
5012\end{array}$ & 0.0800 & $\begin{array}{l}0.0063 \\
.0014\end{array}$ \\
\hline $\begin{array}{l}19 \\
19\end{array}$ & $\begin{array}{r}04 / 22 / 99 \\
09 / 2 / 9\end{array}$ & $\begin{array}{l}1.25300 \\
1.25400\end{array}$ & $\begin{array}{r}5.042 \\
5623\end{array}$ & \begin{tabular}{|l|}
0.0600 \\
\end{tabular} & $\begin{array}{l}0.0061 \\
0.0668\end{array}$ \\
\hline 19 & $01 / 13 / 98$ & 1.25600 & 4.434 & 0.0400 & 0.0068 \\
\hline 19 & $07 / 08 / 97$ & 1.25300 & 5.924 & 0.0800 & 0.0070 \\
\hline 19 & $01 / 21 / 97$ & 1.25200 & 5.706 & 0.0800 & 0.0075 \\
\hline $\begin{array}{l}19 \\
19\end{array}$ & $\begin{array}{l}08 / 101 / 96 \\
11 / 121 / 95\end{array}$ & $\begin{array}{l}1.25200 \\
1.25160\end{array}$ & $\begin{array}{l}5.568 \\
5.5252\end{array}$ & $\begin{array}{l}0.0700 \\
0.0500\end{array}$ & $\begin{array}{l}0.0073 \\
0.0065\end{array}$ \\
\hline $\begin{array}{l}19 \\
19\end{array}$ & $\begin{array}{l}11 / 121 / 95 \\
08 / 26 / 95 \\
\end{array}$ & $\begin{array}{l}\frac{1.25160}{1.21840} \\
\end{array}$ & $\begin{array}{l}5.252 \\
5.558\end{array}$ & $\begin{array}{l}0.0500 \\
0.1000\end{array}$ & $\begin{array}{l}0.0065 \\
0.0075\end{array}$ \\
\hline 19 & $05 / 01 / 95$ & 1.25690 & 5.654 & 0.0600 & 0.0073 \\
\hline 19 & $11 / 15 / 94$ & 1.24920 & 5.572 & 0.1000 & 0.0093 \\
\hline $\begin{array}{l}19 \\
19 \\
\end{array}$ & $\begin{array}{l}08 / 19 / 94 \\
05 / 93 / 94\end{array}$ & $\begin{array}{l}1.24960 \\
1.24893\end{array}$ & $\begin{array}{l}6.151 \\
4.777\end{array}$ & $\begin{array}{l}0.0900 \\
0.0720\end{array}$ & 0.0099 \\
\hline$\frac{19}{19}$ & $\begin{array}{l}05 / 03 / 94 \\
02 / 1 / 49\end{array}$ & $\begin{array}{r}1.24893 \\
1.24722\end{array}$ & $\begin{array}{l}\frac{4.777}{5.733} \\
\end{array}$ & $\begin{array}{l}0.0720 \\
0.0650\end{array}$ & $\begin{array}{l}0.0006 \\
0.0082\end{array}$ \\
\hline 19 & $\begin{array}{l}11 / 24 / 93 \\
\end{array}$ & $\begin{array}{l}1.2 .242 .22 \\
1.24490\end{array}$ & $\begin{array}{l}5 . / 33 \\
5.802\end{array}$ & 0.1600 & $\begin{array}{l}0.0082 \\
0.0074 \\
\end{array}$ \\
\hline 19 & $07 / 23 / 93$ & 1.24400 & 5.667 & 0.0820 & 0.0071 \\
\hline 19 & $04 / 12 / 93$ & $\begin{array}{l}1.24792 \\
.12060\end{array}$ & 5.185 & 0.0660 & 0.0083 \\
\hline 19 & $\begin{array}{l}01 / 18 / 93 \\
10 / 2 / 93\end{array}$ & $\begin{array}{l}1.23860 \\
12000\end{array}$ & $\begin{array}{l}4.862 \\
1902\end{array}$ & 0.0078 & 0.0087 \\
\hline 19 & $\begin{array}{l}10 / 3 / 3 / 92 \\
07 / 30 / 92\end{array}$ & $\begin{array}{l}1.224090 \\
1.23950\end{array}$ & $\begin{array}{l}4.190 \\
4.410\end{array}$ & & \\
\hline 19 & $04 / 06 / 92$ & 1.23890 & 4.610 & & \\
\hline 19 & $01 / 16 / 92$ & 1.24140 & 3.980 & & \\
\hline 19 & $\begin{array}{l}10 / 30 / 91 \\
\end{array}$ & $\begin{array}{l}1.23720 \\
120200\end{array}$ & $\begin{array}{r}4.130 \\
\end{array}$ & & \\
\hline $\begin{array}{l}19 \\
19\end{array}$ & $\begin{array}{c}08 / 03 / 91 \\
07 / 3 / 191\end{array}$ & $\begin{array}{l}1.22200 \\
1.23390\end{array}$ & $\begin{array}{r}4.670 \\
4.300\end{array}$ & & \\
\hline 19 & $04 / 12 / 91$ & $\begin{array}{r}1.233990 \\
1.23590\end{array}$ & $\begin{array}{l}4.300 \\
.519\end{array}$ & & \\
\hline 19 & $02 / 28 / 91$ & 1.22530 & 5.467 & 0.0200 & 0.0110 \\
\hline 19 & $01 / 09 / 91$ & 1.23520 & 1.140 & & \\
\hline $\begin{array}{r}19 \\
19\end{array}$ & $10 / 04 / 90$ & $\begin{array}{l}1.23400 \\
1.18980\end{array}$ & $\begin{array}{r}5.990 \\
\end{array}$ & & \\
\hline $\begin{array}{l}19 \\
19\end{array}$ & $\begin{array}{r}04 / 23 / 90 \\
04 / 3 / 30\end{array}$ & $\begin{array}{r}1.18980 \\
1.77400\end{array}$ & $\begin{array}{r}2.960 \\
2750\end{array}$ & & \\
\hline 19 & $04 / 17 / 90$ & 1.17460 & 2.660 & & \\
\hline 19 & $04 / 17 / 90$ & 1.18810 & 2.730 & & \\
\hline 19 & $\begin{array}{r}03 / 28 / 90 \\
\end{array}$ & $\begin{array}{l}1.16270 \\
1.159020\end{array}$ & 2.283 & & \\
\hline $\begin{array}{r}19 \\
19\end{array}$ & $\begin{array}{r}02 / 23 / 89 \\
02 / 1 / 3 / 8\end{array}$ & $\begin{array}{l}1.15820 \\
1.15900\end{array}$ & $\begin{array}{l}2.010 \\
\end{array}$ & & \\
\hline $\begin{array}{l}19 \\
19 \\
\end{array}$ & $\begin{array}{l}2 / 3 / 389 \\
11 / 26 / 86 \\
\end{array}$ & $\begin{array}{l}.1 .15800 \\
1.01950\end{array}$ & $\begin{array}{r}2.0100 \\
3.400 \\
\end{array}$ & & \\
\hline 19 & $03 / 05 / 85$ & 1.11000 & 2.230 & & \\
\hline 19 & $01 / 27 / 84$ & 1.13000 & 2.820 & & \\
\hline $\begin{array}{l}19 \\
19\end{array}$ & 06/08/83 & $\begin{array}{l}1.13000 \\
120000\end{array}$ & $\begin{array}{r}2.700 \\
\end{array}$ & & \\
\hline $\begin{array}{l}19 \\
19\end{array}$ & $\begin{array}{l}01 / 166 / 83 \\
10 / 15 / 82\end{array}$ & $\begin{array}{l}1.220000 \\
1.15000\end{array}$ & $\begin{array}{l}2.400 \\
1.500\end{array}$ & & \\
\hline 19 & $10 / 15 / 82$ & 1.15000 & 1.800 & & \\
\hline 19 & $09 / 14 / 82$ & 1.08000 & 1.922 & & \\
\hline 19 & $09 / 14 / 82$ & 1.08000 & 1.900 & & \\
\hline $\begin{array}{l}19 \\
19\end{array}$ & 09/07/82 & $\begin{array}{l}1.08000 \\
1 \\
100000\end{array}$ & $\begin{array}{l}2.540 \\
1650\end{array}$ & & \\
\hline $\begin{array}{l}19 \\
19\end{array}$ & $\begin{array}{r}08 / 04 / 82 \\
\end{array}$ & $\begin{array}{r}1.000000 \\
1.11000\end{array}$ & $\begin{array}{l}1.650 \\
1700\end{array}$ & & \\
\hline 19 & $01 / 08 / 82$ & 1.04000 & 0.700 & & \\
\hline 19 & $11 / 30 / 81$ & 1.12000 & 1.400 & & \\
\hline $\begin{array}{l}19 \\
19\end{array}$ & $07 / 03 / 81$ & $\begin{array}{r}1.22000 \\
132000\end{array}$ & $\begin{array}{r}3.600 \\
5.400\end{array}$ & & \\
\hline 19 & $\begin{array}{r}03 / 31 / 81 \\
\end{array}$ & $\begin{array}{r}1.32000 \\
120000\end{array}$ & $\begin{array}{r}5.400 \\
7500\end{array}$ & & \\
\hline $\begin{array}{l}19 \\
19 \\
\end{array}$ & $03 / 02 / 81$ & $\begin{array}{l}1.2 .29000 \\
1.27000\end{array}$ & $\begin{array}{l}1.500 \\
5.300\end{array}$ & & \\
\hline 19 & $12 / 12 / 80$ & 1.25000 & 5.100 & & \\
\hline 19 & $10 / 30 / 80$ & 1.32000 & 3.900 & & \\
\hline 19 & 09/17/80 & $\begin{array}{r}1.35000 \\
13000\end{array}$ & $\begin{array}{r}6.400 \\
6800\end{array}$ & & \\
\hline $\begin{array}{l}19 \\
19\end{array}$ & $\begin{array}{r}09 / 03 / 80 \\
0\end{array}$ & $\begin{array}{r}1.34000 \\
1.20000\end{array}$ & $\begin{array}{l}6.800 \\
5800\end{array}$ & & \\
\hline 19 & $08 / 14 / 80$ & $\begin{array}{l}1.2 .20000 \\
1.28000\end{array}$ & $\begin{array}{l}0.800 \\
1.800\end{array}$ & & \\
\hline 19 & $07 / 21 / 80$ & 1.38000 & 6.400 & & \\
\hline 19 & $07 / 18 / 80$ & 1.39000 & 6.600 & & \\
\hline 19 & $07 / 14 / 80$ & 1.37000 & 5.800 & & \\
\hline 19 & $02 / 20 / 80$ & 1.42000 & 10.000 & & \\
\hline 19 & $02 / 15 / 80$ & 1.40000 & 5.380 & & \\
\hline 19 & $02 / 104 / 80$ & 1.43000 & 10.400 & & \\
\hline 19 & $10 / 14 / 75$ & 1.43000 & 10.961 & 0.6600 & \\
\hline 20 & $04 / 299 / 96$ & $\begin{array}{l}1.24510 \\
\end{array}$ & 2.5331 & 0.0100 & 0.0170 \\
\hline 20 & 16 & 1.49500 & $\frac{1.951}{2057}$ & 0.0020 & 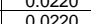 \\
\hline & 0 & 1.21800 & $\frac{1.50}{1888}$ & 0.0100 & 0.0230 \\
\hline & 03 & 1115951 & 2689 & 0.0800 & 0.6 \\
\hline 20 & 194 & 1.24211 & 2829 & 0.0100 & 0.0440 \\
\hline 20 & $09 / 06 / 94$ & 12 & 6.517 & $\frac{0}{00}$ & \\
\hline 20 & $06 / 17 / 94$ & 1.21399 & 3.180 & 0 & 0.0290 \\
\hline 20 & $03 / 17 / 94$ & 1.23470 & 3.426 & 0.0000 & 0.0260 \\
\hline 20 & $12 / 01 / 89$ & 1.22720 & 6.443 & 0.1500 & 0. \\
\hline 20 & $10 / 1$ & 1.21000 & 6.231 & 0.2500 & 0.0260 \\
\hline 20 & $06 / 14 / 93$ & $\begin{array}{l}1.20634 \\
.1 .7020\end{array}$ & 6.206 & 0.2800 & 0.0300 \\
\hline 20 & $\begin{array}{l}03 / 08 / 93 \\
1 / 1 / 49\end{array}$ & $\begin{array}{l}1.17630 \\
123400\end{array}$ & $\begin{array}{r}5.149 \\
3800\end{array}$ & & 0.0310 \\
\hline 20 & $\begin{array}{r}12 / 14 / 92 \\
09 / 15 / 92\end{array}$ & $\begin{array}{l}1.21400 \\
1.11190\end{array}$ & $\begin{array}{l}3.800 \\
11080\end{array}$ & 0.0100 & 0.0400 \\
\hline 20 & $06 / 18 / 92$ & $\frac{1.2150}{1.20050}$ & $\begin{array}{l}1.000 \\
1.580\end{array}$ & & \\
\hline 20 & 05/19/92 & 1.17020 & 0.800 & & \\
\hline 20 & $02 / 04 / 92$ & $\begin{array}{l}1.16860 \\
1.090\end{array}$ & $\begin{array}{r}1.330 \\
\end{array}$ & & \\
\hline 20 & $\begin{array}{l}12 / 11 / 91 \\
09 / 15 / 91\end{array}$ & $\begin{array}{l}1.16880 \\
1.15630\end{array}$ & $\begin{array}{l}1.180 \\
1.070\end{array}$ & & \\
\hline 20 & $04 / 16 / 91$ & 1.14570 & 1.203 & & \\
\hline 20 & $01 / 09 / 91$ & 1.13130 & 0.960 & & \\
\hline 20 & $03 / 28 / 90$ & 1.04420 & 0.057 & & \\
\hline 00 & $12 / 105 / 88$ & 0.96880 & 0.400 & & \\
\hline 20 & $09 / 08 / 88$ & $\frac{1.08840}{1.25140}$ & $\begin{array}{l}0.065 \\
0.180\end{array}$ & & \\
\hline 20 & $08 / 23 / 88$ & 1.3140 & 1.120 & & \\
\hline
\end{tabular}


WSRC-TR-2002-00330, Rev. 0

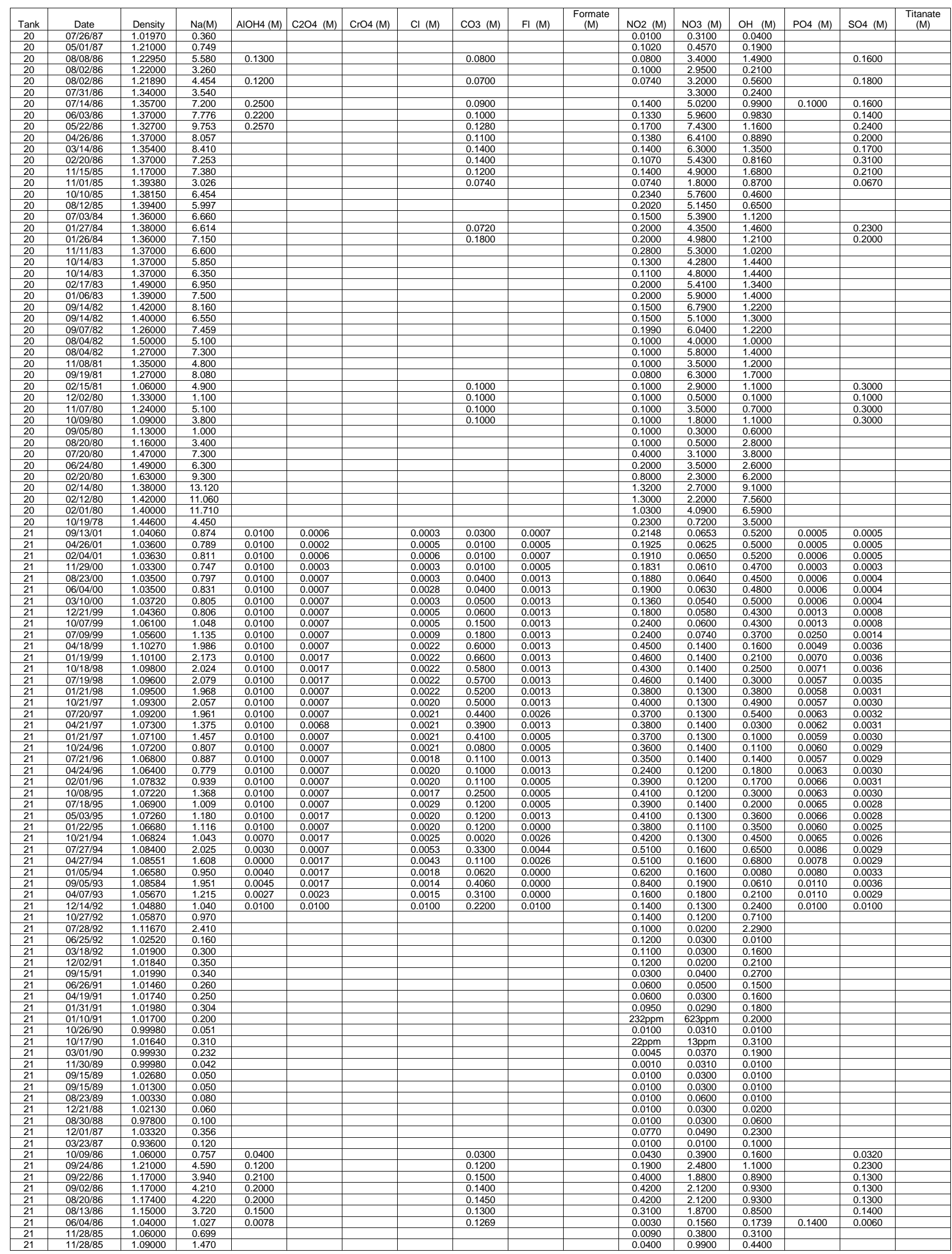


WSRC-TR-2002-00330, Rev. 0

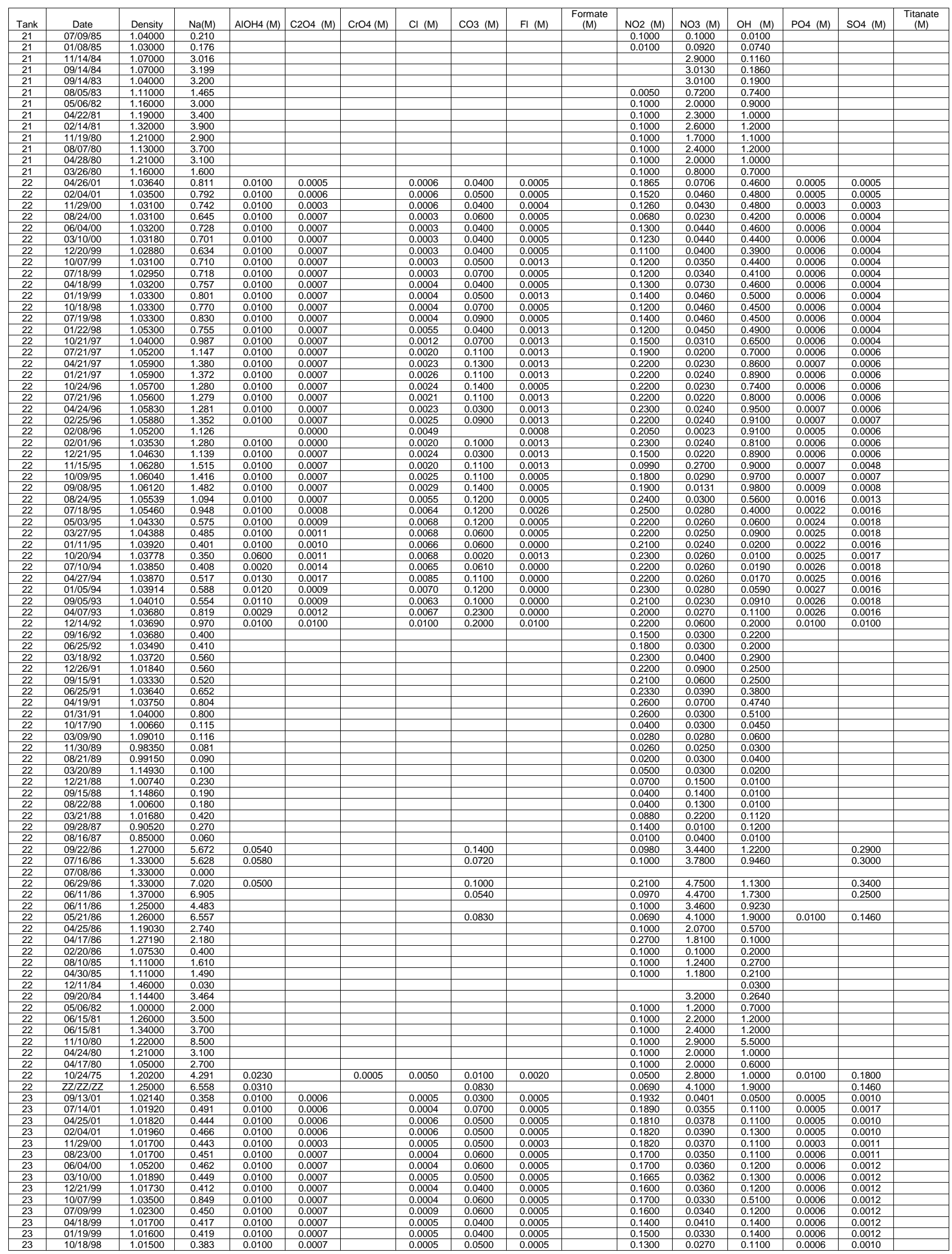


WSRC-TR-2002-00330, Rev. 0

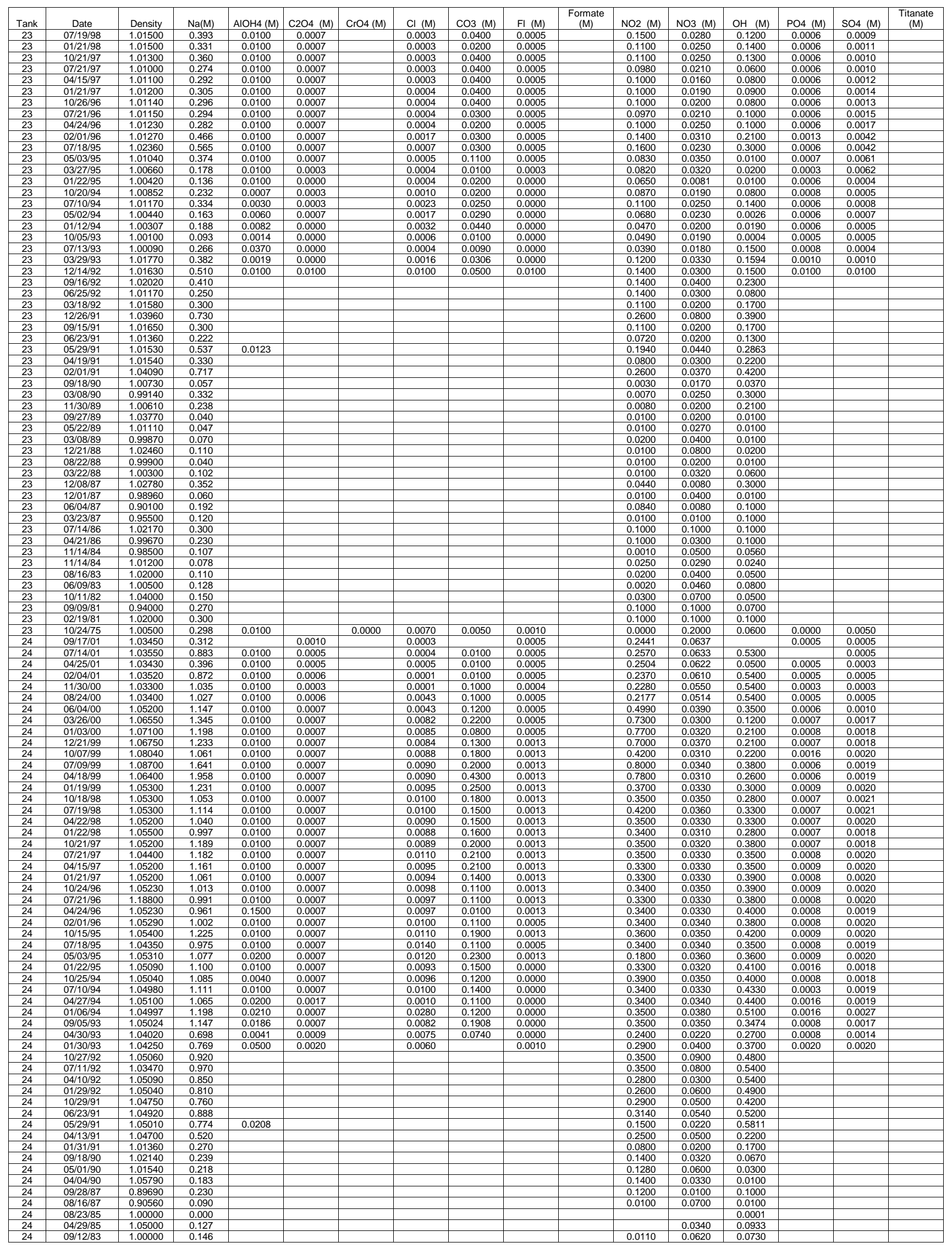


WSRC-TR-2002-00330, Rev. 0

\begin{tabular}{|c|c|c|c|c|c|}
\hline Tank & $\begin{array}{c}\text { Date } \\
09 / 1383\end{array}$ & Density & $\mathrm{Na}(\mathrm{M})$ & $\mathrm{AlOH} 4(\mathrm{M})$ & $\mathrm{C} 2 \mathrm{O} 4(\mathrm{M})$ \\
\hline $\begin{array}{l}24 \\
24\end{array}$ & $\begin{array}{l}09 / 03 / 83 \\
08 / 22 / 83 \\
\end{array}$ & $\begin{array}{l}1.06000 \\
1.50000\end{array}$ & $\begin{array}{l}1.090 \\
11.690\end{array}$ & & \\
\hline 24 & $08 / 22 / 83$ & 1.32000 & 5.040 & & \\
\hline$\frac{24}{24}$ & $\begin{array}{l}08 / 15 / 83 \\
08 / 12 / 83\end{array}$ & $\begin{array}{l}1.38000 \\
138000\end{array}$ & $\begin{array}{l}5.480 \\
5890\end{array}$ & & \\
\hline 24 & $\begin{array}{l}08 / 126 / 83 \\
07 / 26 / 83\end{array}$ & $\begin{array}{l}1.38000 \\
1.34000\end{array}$ & $\begin{array}{l}\frac{3.890}{6.160} \\
\end{array}$ & & \\
\hline 24 & $07 / 18 / 83$ & 1.34000 & 5.980 & & \\
\hline 24 & $06 / 18 / 82$ & 1.34000 & 5.800 & & \\
\hline 24 & $04 / 16 / 82$ & 1.43000 & 6.400 & & \\
\hline$\frac{24}{24}$ & $\begin{array}{l}03 / 099 / 82 \\
01 / 29 / 82\end{array}$ & $\begin{array}{l}1.360000 \\
1.41000\end{array}$ & $\frac{4.300}{6.660}$ & & \\
\hline $\begin{array}{l}24 \\
24\end{array}$ & $\begin{array}{c}11 / 25 / 81 \\
\end{array}$ & $\begin{array}{l}1.470000 \\
\end{array}$ & 18.370 & & \\
\hline 24 & $10 / 20 / 81$ & 1.41000 & 10.050 & 0.5900 & \\
\hline 24 & $10 / 20 / 81$ & 1.44000 & 6.800 & & \\
\hline 24 & $\begin{array}{l}10 / 20 / 81 \\
\end{array}$ & 1.42000 & 6.600 & & \\
\hline$\frac{24}{24}$ & $\begin{array}{l}10 / 06 / 81 \\
08 / 25 / 81\end{array}$ & $\begin{array}{l}1.37000 \\
1.29000\end{array}$ & $\begin{array}{l}6.600 \\
7.400\end{array}$ & & \\
\hline 24 & $\begin{array}{l}08 / 25 / 81 \\
08 / 25 / 81\end{array}$ & $\begin{array}{l}1.29000 \\
1.24000\end{array}$ & $\begin{array}{l}4.400 \\
4.500\end{array}$ & & \\
\hline 24 & $02 / 14 / 81$ & 1.33000 & 6.300 & & \\
\hline 24 & $10 / 24 / 75$ & 1.11300 & 2.647 & 0.0590 & \\
\hline 24 & $02 / 06 / 73$ & 1.39000 & 9.845 & 0.9000 & \\
\hline 25 & $\begin{array}{r}02 / 12 / 198 \\
04 / 10 / 97\end{array}$ & $\begin{array}{l}1.44000 \\
1.45000\end{array}$ & $\begin{array}{l}12.724 \\
13068\end{array}$ & 0.5000 & $\begin{array}{l}0.0068 \\
0.160\end{array}$ \\
\hline 25 & $02 / 13 / 97$ & $\begin{array}{l}1.45000 \\
1.45000\end{array}$ & $\begin{array}{l}13.060 \\
13.832 \\
\end{array}$ & 0.7640 & 0.1160 \\
\hline & $01 / 13 / 97$ & 1.45400 & 12.855 & 0.3400 & 0.0068 \\
\hline $\begin{array}{l}25 \\
25\end{array}$ & $\begin{array}{l}12 / 01 / 95 \\
11 / 10 / 95\end{array}$ & $\begin{array}{l}1.45460 \\
13970\end{array}$ & $\begin{array}{l}14.463 \\
10.440 \\
\end{array}$ & 0.5000 & 0.0067 \\
\hline 25 & $\begin{array}{l}11 / 30 / 95 \\
08 / 31 / 95\end{array}$ & $\begin{array}{l}1.39700 \\
1.44340\end{array}$ & $\frac{10.440}{13505}$ & 0.4700 & 0.0068 \\
\hline 25 & $08 / 18 / 94$ & $\begin{array}{l}1.44040 \\
1.45390\end{array}$ & 13.267 & 0.4700 & 0.0069 \\
\hline 25 & $08 / 05 / 93$ & 1.45900 & 17.455 & 0.6100 & 0.0090 \\
\hline 25 & $07 / 30 / 92$ & 1.45060 & $\begin{array}{l}14.128 \\
12850\end{array}$ & & 0.0050 \\
\hline 25 & $\begin{array}{l}07 / 30 / 92 \\
\end{array}$ & $\begin{array}{l}1.45060 \\
1.820\end{array}$ & $\begin{array}{l}13.850 \\
114068\end{array}$ & & \\
\hline 25 & $\begin{array}{l}0 / 30 / 92 \\
07 / 26 / 91\end{array}$ & $\begin{array}{l}1.48200 \\
1.45500\end{array}$ & $\begin{array}{l}\frac{14.068}{12.970} \\
\end{array}$ & 0.5500 & 0.0050 \\
\hline 25 & $05 / 15 / 89$ & $\begin{array}{l}1.405000 \\
\end{array}$ & 10.200 & & \\
\hline 25 & $11 / 04 / 88$ & 1.46000 & 8.870 & & \\
\hline 25 & $\begin{array}{l}04 / 21 / 88 \\
\end{array}$ & 1.45008 & \begin{tabular}{|l|l|}
20.732 \\
7.12
\end{tabular} & & \\
\hline$\frac{25}{25}$ & $\begin{array}{l}10 / 07 / 87 \\
0404 / 86\end{array}$ & $\begin{array}{l}1.32160 \\
1.460000\end{array}$ & $\begin{array}{l}7.150 \\
11.650\end{array}$ & & \\
\hline 25 & $\begin{array}{l}0404 / 86 \\
08 / 19 / 85 \\
\end{array}$ & $\begin{array}{l}1.460000 \\
1.64000 \\
\end{array}$ & $\begin{array}{l}11.650 \\
8.550\end{array}$ & & \\
\hline 25 & $03 / 19 / 85$ & 1.41000 & 6.370 & & \\
\hline 25 & $02 / 09 / 84$ & 1.41000 & $\begin{array}{l}11.220 \\
10.170\end{array}$ & & \\
\hline 25 & $03 / 18 / 83$ & 1.42000 & $\begin{array}{l}10.470 \\
11700\end{array}$ & & \\
\hline$\frac{25}{25}$ & $\begin{array}{l}06 / 30 / 82 \\
11 / 10 / 81\end{array}$ & $\begin{array}{r}1.47000 \\
1.460\end{array}$ & $\frac{11.700}{8400}$ & & \\
\hline 25 & $11 / / 06 / 81$ & 1.46000 & $\frac{8.400}{11.400}$ & & \\
\hline 25 & $10 / 16 / 81$ & 1.43000 & 6.400 & & \\
\hline 25 & $04 / 08 / 81$ & $\begin{array}{l}1.42000 \\
15200\end{array}$ & 9.000 & & \\
\hline 25 & $\begin{array}{r}09 / 22 / 80 \\
\end{array}$ & $\begin{array}{l}1.52000 \\
1.460\end{array}$ & $\begin{array}{l}10.400 \\
13663\end{array}$ & & 0.0057 \\
\hline 26 & $\begin{array}{l}08 / 15 / 171 \\
\end{array}$ & $\begin{array}{l}1.460000 \\
1.46990 \\
\end{array}$ & $\begin{array}{l}\frac{13.663}{12.439} \\
\end{array}$ & 0.9500 & $0.005 / 1$ \\
\hline 26 & $02 / 27 / 01$ & 1.35130 & 8.530 & 0.3100 & 0.0063 \\
\hline & $12 / 06 / 00$ & 1.32700 & 8.834 & 0.4200 & 0.0058 \\
\hline 26 & $\begin{array}{c}09 / 08 / 00 \\
\end{array}$ & 1.46000 & $\begin{array}{l}14.044 \\
12700\end{array}$ & 0.6300 & 0.0056 \\
\hline 26 & $\begin{array}{l}06 / 30 / 00 \\
\end{array}$ & $\begin{array}{l}1.47000 \\
131000\end{array}$ & $\begin{array}{l}12.729 \\
10.387\end{array}$ & 0.8600 & $\begin{array}{l}0.0012 \\
\end{array}$ \\
\hline 26 & $\begin{array}{l}04 / 111 / 00 \\
12 / 09 / 99\end{array}$ & $\begin{array}{l}1.31000 \\
1.37870\end{array}$ & $\begin{array}{l}0.381 \\
9.774\end{array}$ & $\frac{0.7000}{0.4600}$ & $\begin{array}{l}0.0070 \\
0.0068\end{array}$ \\
\hline 26 & $10 / 06 / 99$ & 1.48431 & 12.536 & 0.7600 & 0.0068 \\
\hline 26 & $07 / 22 / 99$ & 1.43000 & 11.235 & 0.5500 & 0.0068 \\
\hline 26 & $05 / 18 / 99$ & 1.43000 & 9.818 & 0.5200 & 0.0067 \\
\hline 26 & $12 / 02 / 98$ & 1.32000 & 9.629 & 0.4590 & 0.0061 \\
\hline 26 & $09 / 16 / 98$ & 1.41000 & 13.474 & 3.0000 & 0.0068 \\
\hline 26 & $04 / 20 / 98$ & 1.43000 & 11.531 & 0.4100 & 0.0068 \\
\hline 26 & $02 / 18 / 98$ & 1.36000 & 9.636 & 0.3800 & 0.0068 \\
\hline 26 & $12 / 103 / 97$ & 1.42000 & 10.912 & 0.4200 & 0.0068 \\
\hline 26 & 0130097 & $\begin{array}{r}1.40000 \\
1.4290\end{array}$ & $\begin{array}{ll}11.333 \\
1.332\end{array}$ & 0.4800 & 0.0068 \\
\hline 26 & $01 / 13 / 97$ & 1.46900 & 9.530 & $\begin{array}{l}0.4200 \\
0.3200\end{array}$ & $\begin{array}{l}0.0068 \\
0.0068\end{array}$ \\
\hline 26 & $11 / 05 / 96$ & 1.35700 & 7.745 & 0.2200 & 0.0072 \\
\hline 26 & $08 / 01 / 96$ & $\begin{array}{l}1.40900 \\
141300\end{array}$ & $\begin{array}{l}10.033 \\
10361\end{array}$ & $\begin{array}{l}0.1900 \\
0.0100\end{array}$ & 0.0068 \\
\hline 26 & $\begin{array}{r}05 / 17 / 96 \\
11 / 21 / 95\end{array}$ & & & 0.0100 & 0.0071 \\
\hline 26 & $\begin{array}{l}11 / 21 / 95 \\
08 / 18 / 95\end{array}$ & $\begin{array}{l}1.36 / 50 \\
1.33900\end{array}$ & $\frac{8.101}{9192}$ & 0.2800 & $\frac{0.0068}{0.0068}$ \\
\hline 26 & $05 / 11 / 95$ & $\begin{array}{l}1.339000 \\
1.38410\end{array}$ & $\begin{array}{l}\frac{7.153}{8.123} \\
\end{array}$ & 0 & 0.0075 \\
\hline 26 & $02 / 28 / 95$ & 1.42480 & 8.149 & 0.2400 & 0.0090 \\
\hline 26 & $11 / 23 / 94$ & 1.37850 & 9.210 & 0.2600 & 0.0097 \\
\hline 26 & $\begin{array}{c}08 / 20 / 94 \\
\end{array}$ & $\begin{array}{r}1.23140 \\
1.467\end{array}$ & $\begin{array}{l}5.964 \\
15.960\end{array}$ & 0.1100 & 0.0092 \\
\hline 26 & $\begin{array}{r}05 / 03 / 94 \\
0309 / 94\end{array}$ & $\begin{array}{r}1.46708 \\
1.35004\end{array}$ & $\frac{15.860}{12.237}$ & 0.4500 & $\frac{0.0170}{0.0068}$ \\
\hline 26 & $02 / 24 / 93$ & $\begin{array}{l}1.35004 \\
1.38980\end{array}$ & $\frac{12.257}{12.400}$ & 0.45000 & 0.0100 \\
\hline 26 & 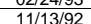 & 1.50500 & 24.140 & 0.5300 & \\
\hline 26 & 08/14/92 & 1.51790 & 16.660 & 0.5400 & \\
\hline 26 & $08 / 14 / 92$ & 1.54600 & 18.179 & 0.5900 & 0.0050 \\
\hline 26 & $05 / 19 / 92$ & 1.50640 & 14.820 & 0.44 & \\
\hline 26 & $02 / 26 / 92$ & 1.43230 & 13.500 & 0.2700 & \\
\hline 26 & $01 / 15 / 92$ & $1.44 \varepsilon$ & 15.288 & 0.4600 & \\
\hline 26 & $11 / /$ & 1.37 & $10.8 \mathrm{r}$ & 0.3500 & \\
\hline 26 & 10/30/91 & $\begin{array}{l}1.259900 \\
1597\end{array}$ & 6.44 & 0.2300 & \\
\hline 26 & 081261 & 1.42500 & 13. & & \\
\hline 26 & $0701 / 91$ & 1.476 & 11. & 0.4200 & \\
\hline 26 & 05/24/91 & 1.45800 & 17 & 0.5170 & \\
\hline 26 & $04 /$ & 1.4 & 12.7 & & \\
\hline & 0 & 11.4 & 15.5 & & \\
\hline 26 & $08 / 15 / 89$ & 1.42260 & 13.2 & & \\
\hline 26 & $02 / 13$ & 1.37030 & 10.040 & & \\
\hline 26 & $10 / 3$ & 1.49420 & 2.8 & & \\
\hline 26 & $04 / 21 / 188$ & 1.53150 & 14.050 & & \\
\hline 26 & 0 & 1.29 & 9.7 & & \\
\hline$\frac{20}{26}$ & $\frac{081}{014}$ & $\begin{array}{l}1.40160 \\
\end{array}$ & $\frac{6.5}{54}$ & & \\
\hline$\frac{20}{26}$ & $05 / 19$ & 1.42800 & $\frac{.4 .40}{4.430}$ & & \\
\hline 26 & & 1.3 & 7 & & \\
\hline 26 & 071 & 1.1 & 4.5 & & \\
\hline 26 & & & & & \\
\hline 26 & $07 / 12 / 83$ & 1.41000 & 11.810 & & \\
\hline 26 & $03 / 18 / 83$ & 1.39000 & 8.31 & & \\
\hline 26 & $12 / 30 / 82$ & 1.39000 & 5.300 & & \\
\hline
\end{tabular}


WSRC-TR-2002-00330, Rev. 0

\begin{tabular}{|c|c|c|c|c|c|c|c|}
\hline Tank & Date & Density & $\mathrm{Na}(\mathrm{M})$ & $\mathrm{AlOH} 4(\mathrm{M})$ & $\mathrm{C} 204$ (M) & $\mathrm{CrO} 4(\mathrm{M})$ & $\mathrm{Cl}(\mathrm{M})$ \\
\hline 26 & $\begin{array}{c}09 / 16 / 82 \\
\end{array}$ & $\begin{array}{l}\text { Detsily } \\
1.32000\end{array}$ & $\begin{array}{l}4.150 \\
\end{array}$ & AlU & $0<\mathrm{V}_{4}(\mathrm{I}$ (II) & CIV4 (III) & \\
\hline 26 & $06 / 21 / 82$ & 1.20000 & 4.500 & & & & \\
\hline 26 & $06 / 03 / 82$ & 1.27000 & 6.000 & & & & \\
\hline $\begin{array}{l}26 \\
26\end{array}$ & $\begin{array}{l}05 / 24 / 82 \\
05 / 2482\end{array}$ & $\begin{array}{l}1.26000 \\
1.26000\end{array}$ & $\begin{array}{l}3.430 \\
3.340 \\
\end{array}$ & & & & \\
\hline 26 & $\begin{array}{l}055 / 242 / 82 \\
0 / 2 / 82\end{array}$ & $\begin{array}{l}1.2 .26000 \\
.49000\end{array}$ & $\begin{array}{l}3.340 \\
10.500\end{array}$ & & & & \\
\hline 26 & $02 / 22 / 82$ & 1.48000 & 10.600 & & & & \\
\hline 26 & $12 / 03 / 81$ & 1.52000 & 9.300 & & & & \\
\hline $\begin{array}{l}26 \\
26\end{array}$ & $06 / 12 / 81$ & $\begin{array}{l}1.42000 \\
142000\end{array}$ & $\begin{array}{l}9.500 \\
7600\end{array}$ & & & & \\
\hline $\begin{array}{l}26 \\
26\end{array}$ & $\begin{array}{l}03 / 24 / 81 \\
09 / 22 / 80\end{array}$ & $\begin{array}{l}1.420000 \\
1.32000\end{array}$ & $\begin{array}{l}7.600 \\
11.400\end{array}$ & & & & \\
\hline 26 & $03 / 06 / 80$ & 1.16000 & 5.100 & & & & \\
\hline 26 & $02 / 01 / 80$ & 1.14000 & 3.020 & & & & \\
\hline 26 & $01 / 25 / 80$ & $\begin{array}{l}1.08000 \\
\end{array}$ & $\begin{array}{l}1.700 \\
1.01\end{array}$ & & & & \\
\hline $\begin{array}{l}27 \\
27\end{array}$ & $\begin{array}{l}06 / 24 / 99 \\
07 / 28 / 97\end{array}$ & $\begin{array}{r}1.48000 \\
1.48000\end{array}$ & $\begin{array}{r}14.012 \\
14319\end{array}$ & $\begin{array}{l}0.0100 \\
10800\end{array}$ & \begin{tabular}{|l|}
0.0067 \\
\end{tabular} & & 0.0210 \\
\hline $\begin{array}{l}27 \\
27\end{array}$ & $\begin{array}{l}0708 / 9797 \\
07 / 09 / 96\end{array}$ & $\begin{array}{l}1.48000 \\
1.45060\end{array}$ & $\begin{array}{l}14.319 \\
12.626 \\
\end{array}$ & $\begin{array}{l}1.0800 \\
0.3400\end{array}$ & $\begin{array}{l}0.0068 \\
0.0068\end{array}$ & & 0.02200 \\
\hline 27 & $08 / 21 / 95$ & 1.43840 & 13.286 & 0.4100 & 0.0069 & & 0.0190 \\
\hline $\begin{array}{l}27 \\
27 \\
\end{array}$ & $08 / 18 / 94$ & $\begin{array}{l}1.46035 \\
145024\end{array}$ & $\begin{array}{l}3.291 \\
15251\end{array}$ & 0.3800 & 0.0170 & & 0.0140 \\
\hline 27 & $08 / 05 / 93$ & 1.45624 & 15.251 & 0.5100 & 0.0090 & & 0.0140 \\
\hline 27 & $07 / 21 / 92$ & $\begin{array}{l}1.50820 \\
150820\end{array}$ & $\begin{array}{l}13.782 \\
1320 \\
\end{array}$ & 0.4200 & 0.0050 & & 0.0210 \\
\hline$\frac{27}{27}$ & $\begin{array}{l}0 / 1 / 21 / 92 \\
07 / 21 / 92\end{array}$ & $\begin{array}{l}1.50820 \\
1.45300\end{array}$ & $\begin{array}{l}13.280 \\
12.962 \\
\end{array}$ & 0.4200 & 0.0050 & & 0.0210 \\
\hline 27 & $08 / 02 / 91$ & 1.42230 & 12.120 & & & & \\
\hline 27 & $05 / 24 / 90$ & 1.43280 & 11.370 & & & & \\
\hline 27 & $\begin{array}{l}05 / 15 / 89 \\
11 / 04 / 88\end{array}$ & $\begin{array}{l}1.40170 \\
120390\end{array}$ & $\begin{array}{l}10.570 \\
6200\end{array}$ & & & & \\
\hline 27 & $\begin{array}{l}11104 / 88 \\
04 / 21 / 88\end{array}$ & $\begin{array}{l}1.263900 \\
1.66810\end{array}$ & $\begin{array}{r}6.200 \\
16.390 \\
\end{array}$ & & & & \\
\hline 27 & $10 / 07 / 87$ & 1.30180 & 7.149 & & & & \\
\hline 27 & $04 / 03 / 87$ & 1.32250 & 2.870 & & & & \\
\hline 27 & 11/25/86 & $\begin{array}{l}1.29840 \\
1.25000\end{array}$ & 6.810 & & & & \\
\hline $\begin{array}{l}27 \\
27 \\
\end{array}$ & $10 / 20 / 84$ & $\begin{array}{l}1.35800 \\
1.40000\end{array}$ & \begin{tabular}{|l|l|}
6.213 \\
0.780
\end{tabular} & & & & \\
\hline 27 & $\begin{array}{r}00 / 90 / 84 \\
08 / 23 / 83 \\
\end{array}$ & $\begin{array}{l}1.40000 \\
1.43000\end{array}$ & $\begin{array}{l}9.780 \\
5.990\end{array}$ & & & & \\
\hline 27 & $03 / 18 / 83$ & $\begin{array}{l}1.45000 \\
1.35000\end{array}$ & 7.170 & & & & \\
\hline 27 & $\begin{array}{l}03 / 25 / 82 \\
\end{array}$ & 1.58000 & 6.800 & & & & \\
\hline 27 & 10/16/81 & $\begin{array}{l}1.30000 \\
1.37000\end{array}$ & $\begin{array}{l}5.700 \\
\end{array}$ & & & & \\
\hline $\begin{array}{l}27 \\
27 \\
\end{array}$ & $\begin{array}{l}08 / 19 / 80 \\
03 / 106 / 80\end{array}$ & $\begin{array}{l}1.37600 \\
1.36000\end{array}$ & $\begin{array}{r}9.500 \\
7.400\end{array}$ & & & & \\
\hline 27 & $\begin{array}{l}03 / 061 / 80 \\
02 / 01 / 80\end{array}$ & $\begin{array}{l}1.330000 \\
.32000\end{array}$ & $\begin{array}{l}7.400 \\
10.280\end{array}$ & & & & \\
\hline 27 & $01 / 25 / 80$ & 1.38000 & 9.540 & & & & \\
\hline 27 & $01 / 24 / 80$ & 1.38000 & 9.540 & & & & \\
\hline $\begin{array}{l}28 \\
28 \\
28\end{array}$ & $\begin{array}{l}06 / 29 / 99 \\
08 / 26 / 99\end{array}$ & $\begin{array}{l}1.46000 \\
1.4000\end{array}$ & $\begin{array}{l}11.578 \\
12092\end{array}$ & $\begin{array}{l}0.5100 \\
0.5800\end{array}$ & \begin{tabular}{|l}
0.0068 \\
00068
\end{tabular} & & $\begin{array}{l}0.0210 \\
00200\end{array}$ \\
\hline $\begin{array}{l}28 \\
28 \\
\end{array}$ & $\begin{array}{l}08 / 26 / 97 \\
08 / 26 / 96\end{array}$ & $\begin{array}{r}1.44000 \\
1.4420\end{array}$ & $\begin{array}{r}12.092 \\
12888\end{array}$ & $\begin{array}{l}0.5800 \\
0.100\end{array}$ & \begin{tabular}{|l|}
0.0068 \\
\end{tabular} & & $\begin{array}{l}0.0200 \\
0,020\end{array}$ \\
\hline 28 & $\begin{array}{l}08 / 26 / 96 \\
08 / 31 / 95\end{array}$ & $\begin{array}{l}1.44420 \\
1.46490\end{array}$ & $\begin{array}{l}1.2888 \\
13.674 \\
\end{array}$ & $\begin{array}{l}0.01000 \\
0.6000\end{array}$ & $\begin{array}{l}0.0068 \\
0.0069\end{array}$ & & $\begin{array}{l}0.0200 \\
0.1000\end{array}$ \\
\hline 28 & $07 / 08 / 94$ & 1.42380 & 13.038 & 0.6300 & 0.0069 & & 0.0084 \\
\hline 28 & $\begin{array}{l}07 / 23 / 93 \\
\end{array}$ & $\begin{array}{l}1.37550 \\
142500\end{array}$ & $\begin{array}{l}11.033 \\
12011\end{array}$ & $\begin{array}{l}0.8800 \\
06100\end{array}$ & 0.0090 & & 0.0110 \\
\hline $\begin{array}{l}28 \\
28 \\
\end{array}$ & $\begin{array}{l}07 / 21 / 92 \\
07 / 21 / 12\end{array}$ & $\begin{array}{l}1.46320 \\
1.43230\end{array}$ & $\begin{array}{l}3.031 \\
12311\end{array}$ & 0.6400 & & & 0.0260 \\
\hline 28 & $\begin{array}{l}0 . / 21 / 92 \\
07 / 21 / 92\end{array}$ & $\begin{array}{l}1.443200 \\
.47400\end{array}$ & $\frac{12.310}{11.911}$ & 0.6400 & & & 0.0260 \\
\hline 28 & $07 / 26 / 91$ & 1.45090 & 11.750 & & & & \\
\hline 28 & $05 / 24 / 90$ & $\begin{array}{l}1.45090 \\
10200\end{array}$ & $\begin{array}{l}12.080 \\
10002\end{array}$ & & & & \\
\hline $\begin{array}{l}28 \\
28\end{array}$ & $05 / 15 / 89$ & $\begin{array}{l}1.43990 \\
148860\end{array}$ & $\begin{array}{l}10.930 \\
11.170\end{array}$ & & & & \\
\hline 28 & $\begin{array}{l}11104 / 88 \\
04 / 21 / 88\end{array}$ & $\begin{array}{l}1.42860 \\
1.57486\end{array}$ & $\begin{array}{l}11.100 \\
13.609\end{array}$ & & & & \\
\hline 28 & $10 / 07 / 87$ & 1.31620 & 7.057 & & & & \\
\hline 28 & $11 / 26 / 86$ & 1.18450 & 4.940 & & & & \\
\hline 28 & $04 / 04 / 86$ & 1.38000 & 9.560 & & & & \\
\hline $\begin{array}{l}28 \\
28\end{array}$ & $\begin{array}{l}08 / 19 / 85 \\
03 / 19 / 85\end{array}$ & $\begin{array}{l}1.41000 \\
14000\end{array}$ & 6.960 & & & & \\
\hline 28 & $\begin{array}{l}03 / 199 / 85 \\
12 / 01 / 83\end{array}$ & $\begin{array}{r}1.44000 \\
1.48000\end{array}$ & $\begin{array}{l}7.450 \\
12350\end{array}$ & & & & \\
\hline 28 & $03 / 18 / 83$ & $\begin{array}{l}1.40000 \\
1.47000\end{array}$ & 10.780 & & & & \\
\hline 28 & $04 / 22 / 82$ & 1.57000 & 13.400 & & & & \\
\hline 28 & 10/16/81 & $\begin{array}{l}1.53000 \\
120000\end{array}$ & $\begin{array}{l}11.900 \\
11.000\end{array}$ & & & & \\
\hline 28 & $\begin{array}{l}04 / 08 / 81 \\
11 / 10 / 80\end{array}$ & $\begin{array}{r}1.28000 \\
15000\end{array}$ & $\begin{array}{r}11.900 \\
1260\end{array}$ & & & & \\
\hline 28 & $09 / 08 / 80$ & $\begin{array}{l}1.554000 \\
1.55000\end{array}$ & 13.400 & & & & \\
\hline 28 & $03 / 13 / 80$ & 1.36000 & 7.900 & & & & \\
\hline 28 & $02 / 01 / 80$ & 1.24000 & 5.940 & & & & \\
\hline $\begin{array}{l}29 \\
29\end{array}$ & $06 / 19 / 01$ & $\begin{array}{r}1.18630 \\
1323800\end{array}$ & $\begin{array}{l}4.097 \\
8.090\end{array}$ & 0.3200 & 0.0064 & & 0.0053 \\
\hline 29 & $\begin{array}{l}05 / 02 / 01 \\
02 / 15 / 01\end{array}$ & $\begin{array}{l}1.3 .3380 \\
1.10000\end{array}$ & $\begin{array}{l}8.990 \\
2.210\end{array}$ & $\begin{array}{l}0 . / 1700 \\
0.1000\end{array}$ & $\begin{array}{l}0.0058 \\
0.0062\end{array}$ & & $\begin{array}{l}0.01199 \\
0.0034\end{array}$ \\
\hline 29 & $12 / 02 / 00$ & 1.36200 & 7.822 & 0.4800 & 0.0057 & & 0.0126 \\
\hline 29 & 09/10/00 & 1.30000 & 6.024 & 0.6200 & 0.0057 & & 0.0094 \\
\hline 29 & $03 / 18 / 00$ & 1.41000 & 9.866 & 0.7700 & 0.0068 & & 0.0082 \\
\hline $\begin{array}{l}29 \\
29 \\
\end{array}$ & 09/24/99 & $\begin{array}{r}1.43000 \\
140000\end{array}$ & $\begin{array}{r}10.192 \\
10599\end{array}$ & $\begin{array}{l}0.4800 \\
07000\end{array}$ & 0.0069 & & $\begin{array}{l}0.0040 \\
00087\end{array}$ \\
\hline 29 & $\frac{03 / 292 / 99}{12 / 0298}$ & $\begin{array}{l}1.40000 \\
1.42000\end{array}$ & $\begin{array}{l}1.559 \\
12.338\end{array}$ & $\begin{array}{l}0.1800 \\
0.8130\end{array}$ & $\begin{array}{l}0.0069 \\
0.0062\end{array}$ & & 0.00054 \\
\hline 29 & $01 / 22 / 98$ & 1.36000 & 8.813 & 0.5800 & 0.0068 & & 0.0074 \\
\hline 29 & $12 / 18 / 96$ & 1.47000 & 11.558 & 0.9400 & 0.0068 & & 0.0100 \\
\hline 29 & $11 / 16 / 95$ & 1.44070 & $\begin{array}{l}11.311 \\
12050\end{array}$ & $\begin{array}{l}0.8400 \\
.8000\end{array}$ & 0.0067 & & $\begin{array}{l}0.0150 \\
.0077\end{array}$ \\
\hline & $\begin{array}{l}11 / 22 / 94 \\
11 / 21 / 93\end{array}$ & $\begin{array}{l}1.44900 \\
1.4140\end{array}$ & $\begin{array}{r}12.052 \\
1462 ?\end{array}$ & $\begin{array}{l}0.8200 \\
1200\end{array}$ & 0.0069 & & $\begin{array}{l}0.0072 \\
0.140\end{array}$ \\
\hline 29 & $11 / 21 / 935$ & $\begin{array}{l}1.45140 \\
1.43000\end{array}$ & $\begin{array}{l}1.6222 \\
11.551 \\
\end{array}$ & $\begin{array}{l}1.9100 \\
0.9300\end{array}$ & \begin{tabular}{|l|}
0.0068 \\
0.0100
\end{tabular} & & $\begin{array}{l}0.0140 \\
0.0170\end{array}$ \\
\hline 29 & $12 / 26 / 91$ & 1.45300 & 9.340 & & & & \\
\hline 29 & $06 / 23 / 91$ & 1.45250 & 9.620 & & & & \\
\hline 29 & $12 / 15 / 89$ & 1.44300 & 10.530 & & & & \\
\hline $\begin{array}{l}29 \\
29\end{array}$ & $\begin{array}{l}05 / 22 / 89 \\
08 / 22 / 88\end{array}$ & $\begin{array}{l}1.41390 \\
1136570\end{array}$ & $\begin{array}{l}9.000 \\
8.650\end{array}$ & & & & \\
\hline 29 & $07 / 17 / 887$ & $\frac{1.505 / 0}{1.13540}$ & 6.710 & & & & \\
\hline 29 & $07 / 17 / 87$ & 1.13 & 6.710 & & & & \\
\hline 29 & $02 / 26 / 85$ & 1.40000 & 8.900 & & & & \\
\hline $\begin{array}{l}29 \\
29 \\
\end{array}$ & 10/12/84 & $\begin{array}{r}1.46600 \\
1.560000\end{array}$ & $\begin{array}{l}7.360 \\
1450\end{array}$ & & & & \\
\hline 29 & $09 / 10 / 83$ & $\begin{array}{l}1.50000 \\
1.48000\end{array}$ & $\frac{14.550}{10.400}$ & & & & \\
\hline 29 & $02 / 1552$ & $\begin{array}{l}1.400000 \\
1.35000\end{array}$ & 9.400 & & & & \\
\hline 29 & & 1.24 & 1.600 & & & & \\
\hline 29 & $11 / 10 / 80$ & & 7400 & & & & \\
\hline 29 & $06 / 20 / 80$ & 1.40000 & 7.458 & 0.1600 & & & \\
\hline 29 & $06 / 17 / 80$ & 1.40000 & 6.200 & & & & \\
\hline 29 & $06 / 10 / 80$ & 1.30000 & 6.200 & & & & \\
\hline 29 & $05 / 28 / 80$ & 1.38000 & 6.700 & & & & \\
\hline 29 & $05 / 19 / 80$ & 1.57000 & 7.890 & & & & \\
\hline 29 & & $\begin{array}{l}1.43000 \\
13000\end{array}$ & $\begin{array}{l}12.050 \\
14.050\end{array}$ & & & & \\
\hline 30 & 0 & 1.400700 & $\begin{array}{l}14.250 \\
11586\end{array}$ & 03900 & & & \\
\hline 30 & $05 / 30 / 01$ & 1.3720 & 6.697 & 0.3900 & & & 0.0072 \\
\hline
\end{tabular}


WSRC-TR-2002-00330, Rev. 0

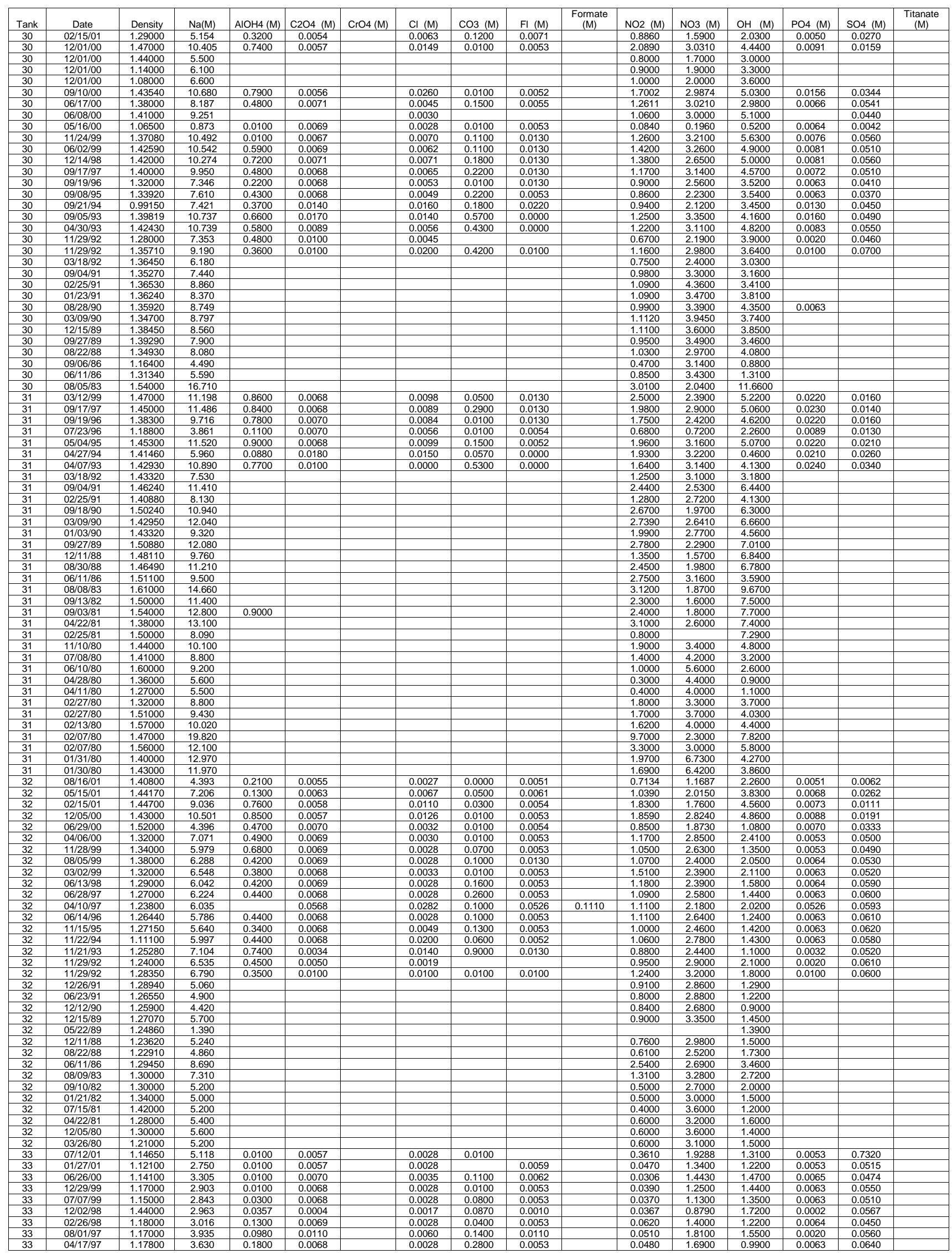


WSRC-TR-2002-00330, Rev. 0

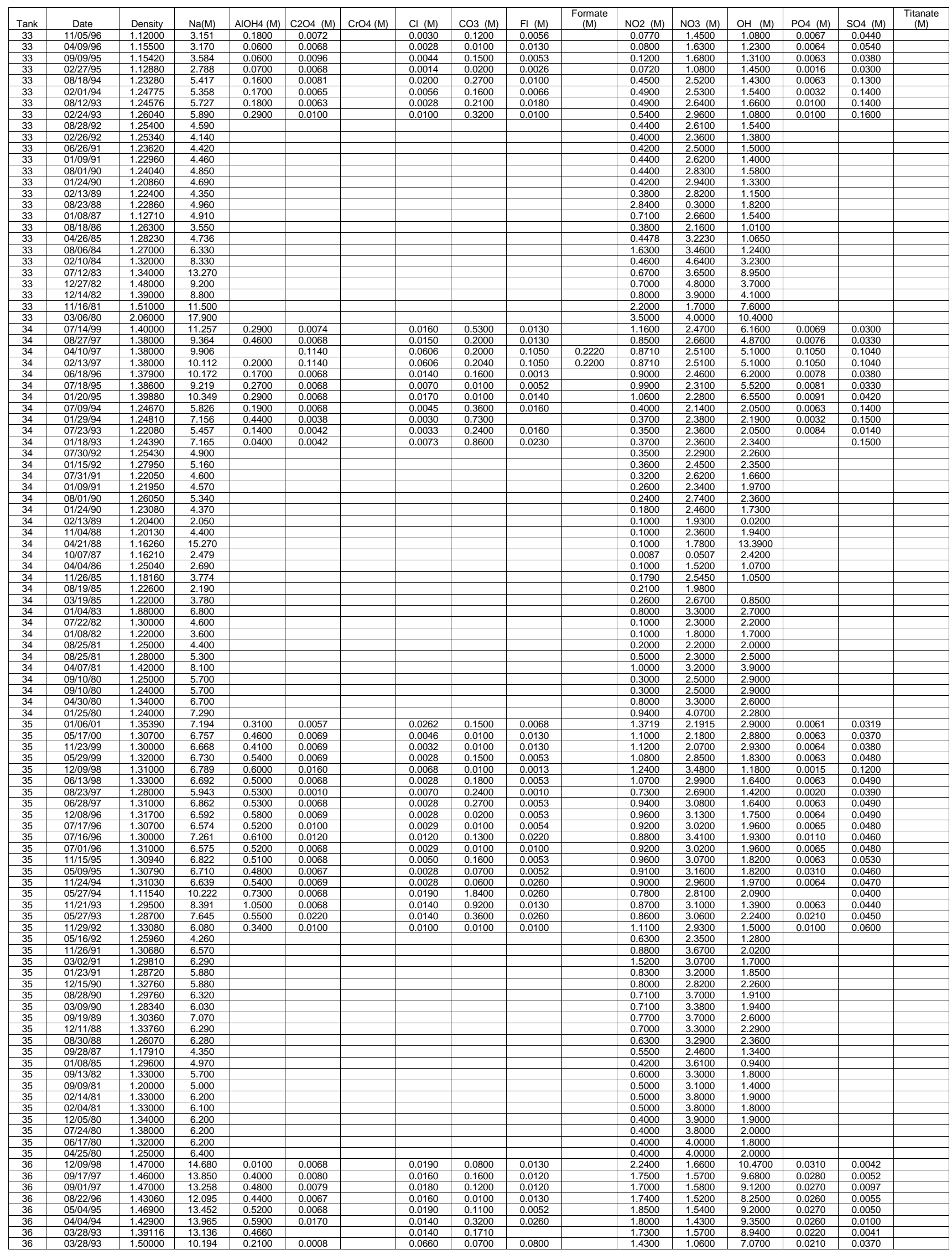


WSRC-TR-2002-00330, Rev. 0

\begin{tabular}{|c|c|c|c|c|c|c|c|}
\hline Tank & Date & Density & $\mathrm{Na}(\mathrm{M})$ & $\mathrm{AlOH} 4(\mathrm{M})$ & $\mathrm{C} 204(\mathrm{M})$ & $\mathrm{CrO} 4(\mathrm{M})$ & $\mathrm{Cl}(\mathrm{M})$ \\
\hline 36 & $03 / 02 / 92$ & 1.50291 & 13.490 & & & & \\
\hline 36 & $03 / 09 / 90$ & 1.48210 & 14.100 & & & & \\
\hline 36 & $01 / 03 / 90$ & 1.46200 & 13.240 & & & & \\
\hline $\begin{array}{l}36 \\
36 \\
\end{array}$ & \begin{tabular}{|l|}
$09 / 29 / 89$ \\
$03 / 20 / 89$ \\
\end{tabular} & $\begin{array}{l}1.48440 \\
1.63720\end{array}$ & $\begin{array}{l}16.560 \\
13.510\end{array}$ & & & & \\
\hline $\begin{array}{l}36 \\
36\end{array}$ & $\begin{array}{l}03 / 201 / 89 \\
03 / 21 / 88\end{array}$ & $\begin{array}{l}1.63720 \\
1.29740\end{array}$ & $\begin{array}{l}13.510 \\
7.164\end{array}$ & & & & \\
\hline 36 & $09 / 28 / 87$ & 1.39000 & 9.960 & & & & \\
\hline 36 & $03 / 23 / 87$ & 1.38300 & 14.980 & & & & \\
\hline 36 & \begin{tabular}{|l|}
$04 / 21 / 86$ \\
$08 / 105 / 83$
\end{tabular} & $\begin{array}{l}1.51370 \\
152000\end{array}$ & \begin{tabular}{|l|}
6.750 \\
11.50
\end{tabular} & & & & \\
\hline $\begin{array}{l}36 \\
36\end{array}$ & $\begin{array}{l}08 / 05 / 83 \\
07 / 17 / 82\end{array}$ & $\begin{array}{l}1.52000 \\
1.68000\end{array}$ & $\begin{array}{l}11.590 \\
9.100\end{array}$ & & & & \\
\hline 36 & $07 / 17 / 82$ & $\begin{array}{l}1.660000 \\
.55000\end{array}$ & $\begin{array}{l}9.100 \\
10.800\end{array}$ & & & & \\
\hline 36 & $09 / 03 / 81$ & 1.41000 & 6.300 & & & & \\
\hline 36 & $02 / 14 / 81$ & $\begin{array}{l}1.30000 \\
150000\end{array}$ & $\begin{array}{l}15.900 \\
12700\end{array}$ & & & & \\
\hline 36 & $\begin{array}{l}11 / 19 / 80 \\
02 / 25 / 80\end{array}$ & $\begin{array}{r}1.58000 \\
130000\end{array}$ & 12.700 & & & & \\
\hline $\begin{array}{l}36 \\
37\end{array}$ & $\begin{array}{l}02 / 25 / 80 \\
09 / 14 / 01\end{array}$ & $\begin{array}{l}1.300000 \\
1.43020\end{array}$ & $\begin{array}{r}9.340 \\
11.463\end{array}$ & 0.4900 & 0.0133 & & 0.0183 \\
\hline 37 & $03 / 12 / 99$ & 1.47000 & 11.971 & 0.4800 & 0.0170 & & 0.0130 \\
\hline 37 & $\begin{array}{l}06 / 29 / 97 \\
\end{array}$ & $\begin{array}{l}1.43000 \\
14000\end{array}$ & $\begin{array}{r}11.510 \\
10502\end{array}$ & 0.4800 & \begin{tabular}{|l|l|}
0 \\
\end{tabular} & & 0.0110 \\
\hline 37 & $04 / 24 / 96$ & 1.43000 & 10.502 & 0.3600 & 0.0068 & & 0.0100 \\
\hline \begin{tabular}{|l}
37 \\
37 \\
\end{tabular} & $\begin{array}{l}03 / 27 / 95 \\
03 / 24 / 94\end{array}$ & $\begin{array}{l}1.41090 \\
1.36100\end{array}$ & $\begin{array}{l}12.319 \\
10.986\end{array}$ & $\begin{array}{l}0.5100 \\
0.9900\end{array}$ & $\begin{array}{l}0.0068 \\
0.0068 \\
\end{array}$ & & $\begin{array}{l}0.0100 \\
0.0004\end{array}$ \\
\hline $\begin{array}{l}37 \\
37\end{array}$ & $\begin{array}{l}03 / 24 / 94 \\
03 / 29 / 93\end{array}$ & $\begin{array}{l}1.36100 \\
1.34650\end{array}$ & $\begin{array}{l}10.986 \\
9.594\end{array}$ & $\begin{array}{l}0.9900 \\
0.4700\end{array}$ & \begin{tabular}{|l|}
0.0068 \\
0.0090
\end{tabular} & & $\frac{0.0000}{0.0056}$ \\
\hline 37 & $03 / 29 / 93$ & 1.40000 & 6.192 & 0.2100 & \begin{tabular}{|l}
0.0018 \\
\end{tabular} & & 0.0640 \\
\hline 37 & $03 / 18 / 92$ & 1.32410 & $\begin{array}{l}5.660 \\
\end{array}$ & & & & \\
\hline $\begin{array}{l}37 \\
37 \\
\end{array}$ & $09 / 04 / 91$ & $\begin{array}{l}1.29850 \\
157410\end{array}$ & $\begin{array}{l}5.860 \\
11.50 \\
\end{array}$ & & & & \\
\hline $\begin{array}{l}37 \\
37 \\
\end{array}$ & $\begin{array}{l}02 / 25 / / 1 \\
01 / 23 / 91\end{array}$ & $\begin{array}{l}1.5 .54710 \\
1.46310\end{array}$ & $\begin{array}{l}11.520 \\
12.130\end{array}$ & & & & \\
\hline 37 & $08 / 28 / 90$ & $\begin{array}{l}1.40010 \\
1.47570\end{array}$ & $\begin{array}{l}1.1 .100 \\
8900\end{array}$ & & & & \\
\hline & $03 / 09 / 90$ & 1.47320 & 13.780 & & & & \\
\hline $\begin{array}{l}37 \\
27\end{array}$ & $01 / 04 / 90$ & $\begin{array}{l}1.50810 \\
1.200\end{array}$ & $\begin{array}{l}13.930 \\
15050\end{array}$ & & & & \\
\hline $\begin{array}{r}37 \\
37 \\
\end{array}$ & 09/29/89 & $\begin{array}{l}1.43420 \\
1.53360\end{array}$ & $\begin{array}{r}15.950 \\
12000\end{array}$ & & & & \\
\hline 37 & $\begin{array}{l}03 / 20 / 89 \\
03 / 21 / 88\end{array}$ & $\begin{array}{l}1.55360 \\
1.52960\end{array}$ & $\begin{array}{l}12.8000 \\
12.387\end{array}$ & & & & \\
\hline 37 & $09 / 28 / 87$ & 1.29230 & 9.360 & & & & \\
\hline 37 & $03 / 23 / 87$ & 1.42470 & 13.690 & & & & \\
\hline $\begin{array}{l}37 \\
37\end{array}$ & $06 / 11 / 86$ & $\begin{array}{l}1.48420 \\
1.5000\end{array}$ & \begin{tabular}{|l|l|}
9.662 \\
10702
\end{tabular} & & & & \\
\hline $\begin{array}{l}37 \\
37 \\
\end{array}$ & $\begin{array}{r}08 / 16 / 83 \\
07 / 17 / 82\end{array}$ & $\begin{array}{l}1.56600 \\
1.51000\end{array}$ & $\begin{array}{l}10.730 \\
11600\end{array}$ & & & & \\
\hline 37 & $09 / 09 / 81$ & $\begin{array}{l}1.551000 \\
1.34000\end{array}$ & $\begin{array}{l}11.600 \\
9.600\end{array}$ & & & & \\
\hline 37 & $02 / 14 / 81$ & 1.34000 & 11.500 & & & & \\
\hline 37 & $12 / 05 / 80$ & 1.35000 & 8.200 & & & & \\
\hline $\begin{array}{l}37 \\
37\end{array}$ & $11 / 19 / 80$ & $\begin{array}{l}1.35000 \\
1.4500\end{array}$ & 8.200 & & & & \\
\hline $\begin{array}{l}37 \\
37 \\
\end{array}$ & $\begin{array}{l}06 / 10 / 80 \\
02 / 25 / 80\end{array}$ & $\begin{array}{l}1.45000 \\
1.40000\end{array}$ & $\begin{array}{l}7.400 \\
11250\end{array}$ & & & & \\
\hline 38 & $\begin{array}{l}02 / 258 / 80 \\
07 / 08 / 01\end{array}$ & $\begin{array}{l}1.40000 \\
1.06350\end{array}$ & $\begin{array}{l}11.250 \\
1.738 \\
\end{array}$ & 0.0100 & 0.0059 & & 0.0029 \\
\hline 38 & $05 / 16 / 01$ & 1.17410 & 3.111 & 0.1600 & 0.0090 & & 0.0033 \\
\hline 38 & $02 / 26 / 00$ & $\begin{array}{l}1.04920 \\
1.16000\end{array}$ & 1.441 & 0.0500 & 0.0057 & & 0.0028 \\
\hline $\begin{array}{l}38 \\
38\end{array}$ & $12 / 15 / 00$ & $\begin{array}{l}1.16000 \\
10900\end{array}$ & $\begin{array}{l}2.495 \\
1667 \\
\end{array}$ & 0.1100 & $\begin{array}{l}0.0057 \\
0059\end{array}$ & & $\begin{array}{l}0.0031 \\
\\
\end{array}$ \\
\hline 38 & $\begin{array}{l}111 / 30 / 00 \\
08 / 27 / 00\end{array}$ & $\begin{array}{l}1.093300 \\
1.09000\end{array}$ & $\begin{array}{l}1.66 / \\
1.893 \\
\end{array}$ & $\begin{array}{l}0.00500 \\
0.0100\end{array}$ & $\begin{array}{l}0.0058 \\
0.0069\end{array}$ & & $\begin{array}{l}0.0054 \\
0.0040\end{array}$ \\
\hline 38 & $06 / 10 / 00$ & 1.24200 & 4.935 & 0.1600 & 0.0111 & & 0.0044 \\
\hline 38 & $03 / 21 / 00$ & 1.13620 & 1.942 & 0.1000 & 0.0068 & & 0.0028 \\
\hline 38 & $12 / 18 / 99$ & $\begin{array}{l}1.30220 \\
120200\end{array}$ & 6.385 & 0.2800 & 0.0140 & & 0.0048 \\
\hline $\begin{array}{l}38 \\
38\end{array}$ & $\begin{array}{l}11 / 29 / 99 \\
08 / 25 / 99\end{array}$ & $\begin{array}{l}1.23000 \\
1.42090\end{array}$ & $\begin{array}{l}4.118 \\
11.052\end{array}$ & $\begin{array}{l}0.28800 \\
0.2600\end{array}$ & $\begin{array}{l}0.0140 \\
0.0150\end{array}$ & & $\begin{array}{l}0.00033 \\
0.0080\end{array}$ \\
\hline 38 & $03 / 07 / 99$ & 1.52000 & 11.411 & 0.1200 & 0.0180 & & 0.0096 \\
\hline 38 & $11 / 30 / 98$ & 1.24000 & 7.124 & 0.0100 & 0.0120 & & 0.0057 \\
\hline 38 & $08 / 30 / 98$ & $\begin{array}{l}1.39000 \\
10000\end{array}$ & $\begin{array}{l}10.612 \\
7019\end{array}$ & 0.1500 & 0.0068 & & 0.0100 \\
\hline $\begin{array}{l}38 \\
38\end{array}$ & $\begin{array}{l}05 / 26 / 98 \\
02 / 25 / 98\end{array}$ & $\begin{array}{l}1.29000 \\
1.4000\end{array}$ & \begin{tabular}{|l|l|}
7.218 \\
10218 \\
\end{tabular} & $\begin{array}{l}0.0300 \\
0.3600\end{array}$ & 0.1500 & & $\begin{array}{l}0.0076 \\
00120\end{array}$ \\
\hline $\begin{array}{l}38 \\
38\end{array}$ & $\begin{array}{r}02 / 25 / 98 \\
11 / 101 / 97\end{array}$ & $\begin{array}{r}1.41000 \\
1.30000\end{array}$ & $\begin{array}{l}10.218 \\
8492\end{array}$ & $\begin{array}{l}0.3600 \\
0.200\end{array}$ & $\begin{array}{l}0.0068 \\
0.0688\end{array}$ & & $\begin{array}{l}0.0120 \\
0.090\end{array}$ \\
\hline 38 & $\begin{array}{l}11 / 1 / 1 / 7 \\
08 / 09 / 97\end{array}$ & $\begin{array}{l}1.300000 \\
1.30000\end{array}$ & $\begin{array}{l}8.492 \\
7.845 \\
\end{array}$ & $\begin{array}{l}0.2200 \\
0.2700\end{array}$ & $\begin{array}{l}0.0008 \\
0.0069\end{array}$ & & $\begin{array}{l}0.0900 \\
0.0090\end{array}$ \\
\hline 38 & $05 / 09 / 97$ & 1.45700 & 14.959 & 3.0000 & 0.0068 & & 0.0140 \\
\hline 38 & $02 / 25 / 97$ & 1.42000 & 12.049 & 0.2600 & 0.0068 & & 0.0130 \\
\hline $\begin{array}{l}38 \\
38\end{array}$ & 10/03/96 & $\begin{array}{r}1.40100 \\
14300\end{array}$ & $\begin{array}{r}10.769 \\
11202 \\
\end{array}$ & 0.0100 & \begin{tabular}{|l}
0.0089 \\
\end{tabular} & & \\
\hline $\begin{array}{l}0 \\
38 \\
\end{array}$ & $\begin{array}{l}10 / 03 / 96 \\
07 / 23 / 96\end{array}$ & $\begin{array}{l}1.44400 \\
1.35900\end{array}$ & $\begin{array}{l}11.222 \\
8.976\end{array}$ & $\begin{array}{l}.3 .3400 \\
0.1500\end{array}$ & 0.0070 & & 0.0 .0140 \\
\hline 38 & $06 / 20 / 96$ & 1.29600 & 7.563 & 0.1200 & 0.0074 & & 0.0110 \\
\hline 38 & $02 / 01 / 96$ & 1.37500 & 9.832 & 0.3000 & 0.0068 & & 0.0150 \\
\hline 38 & $\begin{array}{l}10 / 15 / 95 \\
\end{array}$ & $\begin{array}{r}1.17540 \\
1.16012\end{array}$ & $\begin{array}{l}3.768 \\
3936\end{array}$ & 0.1700 & 0.0068 & & $\begin{array}{l}0.0069 \\
\end{array}$ \\
\hline $\begin{array}{l}38 \\
38\end{array}$ & $\begin{array}{r}09 / 07 / 95 \\
\\
07 / 18 / 15\end{array}$ & $\begin{array}{l}1.16012 \\
147490\end{array}$ & $\begin{array}{l}3.936 \\
12340\end{array}$ & 0.1200 & \begin{tabular}{|l|}
0.0068 \\
\end{tabular} & & $\begin{array}{l}0.0048 \\
0.071\end{array}$ \\
\hline 38 & $05 / 03 / 95$ & $\begin{array}{l}1.44490 \\
1.43100\end{array}$ & $\begin{array}{l}1.540 \\
11.528 \\
\end{array}$ & $\begin{array}{l}0.4500 \\
0.5400\end{array}$ & $\begin{array}{l}0.00067 \\
0.0067\end{array}$ & & 0.0180 \\
\hline 38 & $01 / 26 / 95$ & 1.13550 & 10.617 & 0.3900 & 0.0066 & & 0.0130 \\
\hline 38 & $09 / 28 / 94$ & 1.49570 & 15.424 & \begin{tabular}{l|l|}
0.5074 \\
05800
\end{tabular} & 0.0067 & & 0.0280 \\
\hline $\begin{array}{l}38 \\
38\end{array}$ & $\begin{array}{c}07 / 14 / 94 \\
\end{array}$ & $\begin{array}{r}1.47700 \\
1.35410\end{array}$ & $\begin{array}{r}18.343 \\
0.733\end{array}$ & 0.5800 & \begin{tabular}{|l|}
0.0068 \\
\end{tabular} & & $\begin{array}{l}0.0028 \\
0.007\end{array}$ \\
\hline $\begin{array}{l}50 \\
38\end{array}$ & $\begin{array}{l}10 / 04 / 1 / 33 \\
07 / 13 / 93\end{array}$ & $\begin{array}{l}1.534510 \\
1.45603\end{array}$ & $\begin{array}{l}9.133 \\
12.793\end{array}$ & $\begin{array}{l}0.4000 \\
0.4800\end{array}$ & \begin{tabular}{|l|}
0.0068 \\
0.0090
\end{tabular} & & 0.00140 \\
\hline 38 & $03 / 03 / 93$ & 1.36430 & 11.076 & 0.3000 & $\begin{array}{l}0.0220 \\
\end{array}$ & & 0.0140 \\
\hline 38 & $11 / 24 / 92$ & 1.47000 & 12.891 & 0.5300 & 0.0050 & & 0.0200 \\
\hline 38 & $11 / 24 / 92$ & $\begin{array}{l}1.47880 \\
1.12800\end{array}$ & $\begin{array}{l}15.440 \\
15100\end{array}$ & 0.4900 & & & \\
\hline 38 & $\begin{array}{l}09 / 14 / 92 \\
06 / 25 / 92\end{array}$ & $\frac{1.42880}{1141340}$ & $\begin{array}{r}15.490 \\
9800\end{array}$ & 0.23300 & & & \\
\hline 38 & $03 / 16 / 92$ & $\begin{array}{l}1.41540 \\
1.46070\end{array}$ & 13.090 & 0.5500 & & & \\
\hline 38 & $12 / 26 / 91$ & 1.46360 & 12.220 & 0.3100 & & & \\
\hline 38 & $11 / 26 / 91$ & 1.46520 & 13.330 & & & & \\
\hline 38 & 10/01/91 & $\begin{array}{l}1.44980 \\
15080\end{array}$ & $\begin{array}{l}13.450 \\
1.802\end{array}$ & 0.3800 & & & \\
\hline $\begin{array}{l}38 \\
38\end{array}$ & $\begin{array}{l}08 / 28 / 91 \\
07 / 26 / 91\end{array}$ & $\begin{array}{l}1.54980 \\
1.43893 \\
\end{array}$ & $\begin{array}{l}13.830 \\
10.520\end{array}$ & & & & \\
\hline 38 & $05 / 29 / 91$ & $\begin{array}{l}1.44095 \\
1.45890\end{array}$ & $\begin{array}{l}1.50 \mathrm{U} \\
12.294\end{array}$ & 0.4900 & & & \\
\hline 38 & $02 / 25 / 91$ & 1.27 & 4.600 & & & & \\
\hline 38 & $01 / 23 / 91$ & $\begin{array}{l}1.38310 \\
13000\end{array}$ & $\begin{array}{l}9.850 \\
\end{array}$ & & & & \\
\hline $\begin{array}{l}38 \\
38\end{array}$ & 03/09/90 & $\begin{array}{r}1.38980 \\
1117230\end{array}$ & $\begin{array}{l}10.570 \\
3400\end{array}$ & & & & \\
\hline 38 & $02 / 13 / 89$ & 1.17 & $\frac{3.400}{13200}$ & & & & \\
\hline 38 & $08 / 22 / 88$ & 1.08140 & 2.250 & & & & \\
\hline 38 & 03 & 1.3 & 9.492 & & & & \\
\hline 38 & & 118430 & 4.600 & & & & \\
\hline 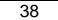 & $01 / 01 / 87$ & 1.17200 & 6.100 & & & & \\
\hline 38 & $09 / 09 / 86$ & 0.98760 & 2.460 & & & & \\
\hline 38 & $09 / /$ & 1.07600 & 3.126 & & & & \\
\hline 38 & 09/09/86 & 1.07 & 3.146 & & & & \\
\hline 势8 & $04 / 21 / 86$ & 1.27790 & 2.180 & & & & \\
\hline 势 & $04 / 21786$ & $\frac{1.27190}{1.2719}$ & $\begin{array}{l}3.478 \\
3.590\end{array}$ & & & & \\
\hline 38 & $\begin{array}{l}04 / 2400 \\
12106 / 84\end{array}$ & $\frac{1.2140}{1.2000}$ & $\begin{array}{l}.5304 \\
1364\end{array}$ & & & & \\
\hline 38 & $12 / 106 / 84$ & 1.24000 & 3.360 & & & & \\
\hline
\end{tabular}


WSRC-TR-2002-00330, Rev. 0

\begin{tabular}{|c|c|c|c|c|c|}
\hline Tank & Date & Density & $\mathrm{Na}(\mathrm{M})$ & AlOH4 (M & $\mathrm{C} 204(\mathrm{M})$ \\
\hline 38 & $03 / 12 / 83$ & 1.07000 & 1.460 & & \\
\hline 38 & $02 / 18 / 83$ & 1.42000 & $\begin{array}{l}1.700 \\
\end{array}$ & & \\
\hline 38 & $09 / 13 / 82$ & 1.16000 & 1.960 & & \\
\hline \begin{tabular}{|l}
38 \\
38
\end{tabular} & $\begin{array}{l}06 / 18 / 82 \\
05 / 14 / 82\end{array}$ & $\begin{array}{l}1.38000 \\
1.50000\end{array}$ & $\begin{array}{l}9.000 \\
10.100\end{array}$ & & \\
\hline 38 & $\begin{array}{l}05 / 144 / 82 \\
05 / 06 / 82\end{array}$ & $\begin{array}{l}1.54000 \\
1.18000\end{array}$ & $\frac{10.100}{2.800}$ & & \\
\hline 38 & $01 / 28 / 82$ & 1.17000 & 3.200 & & \\
\hline 39 & $07 / 08 / 01$ & 1.23610 & 5.721 & 0.0100 & 0.0064 \\
\hline 39 & $02 / 02 / 01$ & 1.32000 & 5.506 & 0.3100 & 0.0057 \\
\hline 39 & $07 / 30 / 00$ & 1.30000 & 6.000 & 0.3300 & 0.0069 \\
\hline & $02 / 17 / 00$ & 1.28000 & 5.709 & 0.1500 & 0.0068 \\
\hline 39 & $08 / 25 / 99$ & 1.28050 & 6.413 & 0.2600 & 0.0068 \\
\hline 39 & 03/07/99 & 1.28000 & 5.695 & 0.1400 & 0.0068 \\
\hline 39 & 09/07/98 & $\begin{array}{l}1.26000 \\
1.25000\end{array}$ & \begin{tabular}{|l|l|}
6.037 \\
5780
\end{tabular} & 0.2600 & 0.0069 \\
\hline $\begin{array}{l}39 \\
39\end{array}$ & $\begin{array}{r}03 / 17 / 178 \\
09 / 17 / 97\end{array}$ & $\begin{array}{l}\frac{1.25000}{1.22000} \\
\end{array}$ & $\begin{array}{l}5.899 \\
6.060\end{array}$ & $\begin{array}{l}0.2200 \\
0.1700\end{array}$ & $\begin{array}{l}0.0068 \\
0.0068\end{array}$ \\
\hline 39 & $04 / 10 / 97$ & 1.24600 & $\begin{array}{l}0.000 \\
5.129\end{array}$ & 0.4510 & 0.0310 \\
\hline 39 & $12 / 02 / 96$ & 1.38800 & 6.562 & 0.4200 & 0.0068 \\
\hline 39 & $06 / 19 / 96$ & $\begin{array}{l}1.31000 \\
1.30000\end{array}$ & $\begin{array}{l}6.764 \\
6.807 \\
\end{array}$ & 0.5400 & \begin{tabular}{|l}
0068 \\
\end{tabular} \\
\hline 39 & $11 / 16 / 95$ & 1.29800 & 6.807 & 0.4000 & 0.0068 \\
\hline \begin{tabular}{|l}
39 \\
39 \\
\end{tabular} & $\begin{array}{r}05 / 09 / 95 \\
112 / 2 / 94\end{array}$ & $\begin{array}{l}1.29290 \\
1.30290\end{array}$ & \begin{tabular}{|l|l|}
7.463 \\
6.490 \\
\end{tabular} & $\begin{array}{l}0.4100 \\
0.5100\end{array}$ & \begin{tabular}{|l|}
0.0067 \\
0.068
\end{tabular} \\
\hline $\begin{array}{l}39 \\
39 \\
\end{array}$ & $\begin{array}{r}1112 / 2 / 44 \\
05 / 31 / 94\end{array}$ & $\begin{array}{l}1.302900 \\
1.21840\end{array}$ & $\begin{array}{l}6.490 \\
5.928 \\
\end{array}$ & $\begin{array}{l}0.51100 \\
0.4300\end{array}$ & \begin{tabular}{|l|}
0.0068 \\
0.0007
\end{tabular} \\
\hline 39 & $11 / 21 / 93$ & 1.29400 & $\begin{array}{l}.219 \\
\end{array}$ & 0.8000 & 0.0047 \\
\hline 39 & $11 / 29 / 92$ & $\begin{array}{l}1.32210 \\
.32200\end{array}$ & 7.270 & 0.3200 & 0.0100 \\
\hline 39 & $\begin{array}{l}03 / 16 / 92 \\
01 / 4 / 19\end{array}$ & $\begin{array}{l}1.28550 \\
133800\end{array}$ & $\begin{array}{l}4.690 \\
6520 \\
652\end{array}$ & & \\
\hline $\begin{array}{l}39 \\
39\end{array}$ & $\begin{array}{l}01 / 14 / 92 \\
09 / 04 / 91\end{array}$ & $\begin{array}{r}1.308000 \\
1.29800\end{array}$ & $\begin{array}{l}6.520 \\
5.860\end{array}$ & & \\
\hline 39 & $03 / 02 / 91$ & 1.29260 & 6.740 & & \\
\hline 39 & $09 / 18 / 90$ & 1.35360 & 7.000 & & \\
\hline 39 & $04 / 09 / 90$ & $\begin{array}{l}1.27620 \\
150270\end{array}$ & $\begin{array}{l}5.900 \\
\end{array}$ & & \\
\hline $\begin{array}{r}39 \\
39 \\
\end{array}$ & $\begin{array}{l}05 / 22 / 89 \\
2 / 11 / 88\end{array}$ & $\begin{array}{l}1.52870 \\
1336000\end{array}$ & $\begin{array}{r}5.010 \\
\end{array}$ & & \\
\hline $\begin{array}{l}399 \\
39 \\
\end{array}$ & $\begin{array}{l}121 / 1188 \\
12 / 01 / 87 \\
\end{array}$ & $\begin{array}{l}1.306000 \\
1.29840\end{array}$ & $\begin{array}{l}4.920 \\
4.480 \\
\end{array}$ & & \\
\hline 39 & $03 / 23 / 87$ & 1.19450 & 5.380 & & \\
\hline 39 & $09 / 09 / 86$ & 1.15710 & $\begin{array}{l}4.220 \\
\end{array}$ & & \\
\hline $\begin{array}{l}39 \\
39\end{array}$ & $07 / 14 / 86$ & $\begin{array}{l}1.31380 \\
1.30200\end{array}$ & 5.120 & & \\
\hline $\begin{array}{r}39 \\
39 \\
\end{array}$ & $\begin{array}{l}03 / 14 / 86 \\
08 / 12 / 85\end{array}$ & $\begin{array}{l}1.30200 \\
1.32800\end{array}$ & \begin{tabular}{|l|l|}
4.294 \\
5218 \\
\end{tabular} & & \\
\hline 39 & $07 / 09 / 85$ & $\begin{array}{l}1.338800 \\
1.39000\end{array}$ & $\begin{array}{r}0.110 \\
4.340 \\
\end{array}$ & & \\
\hline 39 & $08 / 03 / 84$ & 1.35000 & 6.090 & & \\
\hline 39 & $02 / 21 / 84$ & $\begin{array}{l}1.33000 \\
12000\end{array}$ & $\begin{array}{l}7.300 \\
11.270\end{array}$ & & \\
\hline $\begin{array}{l}399 \\
39\end{array}$ & $\begin{array}{l}08 / 18 / 83 \\
02 / 5 / 153\end{array}$ & $\begin{array}{l}1.34000 \\
133000\end{array}$ & $\begin{array}{l}11.370 \\
5.270\end{array}$ & & \\
\hline $\begin{array}{l}39 \\
39 \\
\end{array}$ & $\begin{array}{l}02 / 15 / 83 \\
07 / 20 / 82\end{array}$ & $\begin{array}{l}1.30000 \\
1.32000\end{array}$ & $\begin{array}{l}5.270 \\
4.400\end{array}$ & & \\
\hline 39 & $\begin{array}{l}03 / 09 / 82 \\
\end{array}$ & $\begin{array}{l}1.330000 \\
1.24000\end{array}$ & $\begin{array}{l}4.400 \\
6.100\end{array}$ & & \\
\hline 40 & $09 / 18 / 01$ & 1.04850 & 0.097 & 0.0100 & 0.0009 \\
\hline 40 & $07 / 22 / 01$ & 1.02440 & 1.273 & 0.0200 & 0.0115 \\
\hline 40 & $\begin{array}{l}07 / 22 / 01 \\
\end{array}$ & $\begin{array}{l}1.05300 \\
105650\end{array}$ & $\begin{array}{l}1.261 \\
1.846\end{array}$ & 0.0200 & $\begin{array}{l}0.0162 \\
00203\end{array}$ \\
\hline $\begin{array}{l}40 \\
40\end{array}$ & $\begin{array}{l}06 / 14 / 01 \\
07 / 10 / 00\end{array}$ & $\begin{array}{l}1.00550 \\
1.14000\end{array}$ & $\begin{array}{l}1.846 \\
2.156\end{array}$ & 0.0100 & 0.02240 \\
\hline 40 & $07 / 10 / 00$ & 1.11000 & 2.355 & & 0.0270 \\
\hline 40 & $04 / 18 / 00$ & 1.17000 & 3.527 & 0.1800 & 0.0110 \\
\hline 40 & $10 / 23 / 99$ & $\begin{array}{l}1.32000 \\
130000\end{array}$ & $\begin{array}{l}7.866 \\
9.191\end{array}$ & 0.2000 & 0.0067 \\
\hline $\begin{array}{l}40 \\
40\end{array}$ & $\begin{array}{c}03 / 29 / 99 \\
09 / 28 / 98\end{array}$ & $\begin{array}{r}1.36000 \\
133000\end{array}$ & $\begin{array}{r}9.181 \\
8.538 \\
\end{array}$ & $\begin{array}{l}0.2800 \\
01500\end{array}$ & $\begin{array}{l}0.0068 \\
00067\end{array}$ \\
\hline 40 & $\begin{array}{l}09 / 280 / 98 \\
03 / 30\end{array}$ & $\begin{array}{l}1.330000 \\
1.33000\end{array}$ & 8.638 & 0.10000 & $\begin{array}{l}0.000 \% 9 \\
0.0069\end{array}$ \\
\hline 40 & $01 / 01 / 98$ & 1.35000 & 7.890 & 0.2200 & 0.0061 \\
\hline 40 & $06 / 26 / 97$ & 1.34000 & 8.767 & 0.3000 & 0.0068 \\
\hline 40 & $04 / 05 / 96$ & $\begin{array}{l}1.36700 \\
1.8000\end{array}$ & $\begin{array}{l}9.522 \\
2.01 \\
\end{array}$ & 0.2600 & 0.0076 \\
\hline $\begin{array}{l}40 \\
40\end{array}$ & $\begin{array}{r}02 / 26 / 96 \\
10 / 27 / 95\end{array}$ & $\begin{array}{r}1.18000 \\
1116010\end{array}$ & $\begin{array}{r}2.601 \\
3.511 \\
\end{array}$ & 00800 & 0.0172 \\
\hline 40 & $08 / 23 / 95$ & $\begin{array}{l}1.1 .10010 \\
.15122\end{array}$ & $\begin{array}{l}3.511 \\
2.987 \\
\end{array}$ & $\begin{array}{l}0.0800 \\
0.0700\end{array}$ & $\begin{array}{l}0.0200 \\
0.0210\end{array}$ \\
\hline 40 & $05 / 10 / 95$ & 1.16770 & 3.492 & 0.0900 & 0.0240 \\
\hline 40 & $12 / 18 / 94$ & $\begin{array}{l}1.13024 \\
.1 .57070\end{array}$ & $\begin{array}{l}2.671 \\
027\end{array}$ & 0.1200 & 0.0250 \\
\hline 40 & $06 / 29 / 94$ & $\begin{array}{l}1.15570 \\
1.15010\end{array}$ & $\begin{array}{l}3.397 \\
\end{array}$ & 0.1000 & 0.0250 \\
\hline $\begin{array}{l}40 \\
40\end{array}$ & $\begin{array}{l}01 / 22 / 94 \\
08 / 24 / 93\end{array}$ & $\begin{array}{l}.15810 \\
1.15839\end{array}$ & $\begin{array}{l}3.497 \\
3.487 \\
\end{array}$ & $\begin{array}{l}0.1100 \\
0.1200\end{array}$ & $\begin{array}{l}0.0190 \\
0.0190\end{array}$ \\
\hline 40 & $03 / 01 / 93$ & 1.18600 & 3.630 & 0.0991 & 0.0190 \\
\hline 40 & 12/28/92 & $\begin{array}{l}1.34000 \\
121000\end{array}$ & \begin{tabular}{|l|l|}
8.531 \\
2750
\end{tabular} & 0.2600 & 0.0034 \\
\hline 40 & $\begin{array}{r}08 / 28 / 92 \\
\end{array}$ & $\begin{array}{l}1.21200 \\
115120\end{array}$ & $\begin{array}{l}2.750 \\
2360\end{array}$ & & \\
\hline $\begin{array}{l}40 \\
40\end{array}$ & $\begin{array}{l}02 / 17 / 92 \\
11 / 19 / 91\end{array}$ & $\begin{array}{l}1.1 .15120 \\
1.15030\end{array}$ & $\begin{array}{l}2.360 \\
2.320\end{array}$ & & \\
\hline 40 & $04 / 17 / 91$ & 1.14820 & 2.030 & & \\
\hline 40 & $01 / 26 / 91$ & 1.14760 & 2.370 & & \\
\hline 40 & $11 / 17 / 90$ & 1.14600 & 2.700 & & \\
\hline 40 & $\begin{array}{r}02 / 12 / 90 \\
08 / 23 / 89\end{array}$ & $\begin{array}{r}1.12850 \\
1118990\end{array}$ & $\begin{array}{l}2.483 \\
2.680 \\
\end{array}$ & & \\
\hline $\begin{array}{l}40 \\
40\end{array}$ & $\begin{array}{l}08 / 23 / 89 \\
05 / 22 / 89\end{array}$ & $\begin{array}{l}1.12890 \\
1.14880\end{array}$ & $\begin{array}{l}2.680 \\
1.980\end{array}$ & & \\
\hline 40 & $03 / 20 / 89$ & 1.18650 & 1.850 & & \\
\hline 40 & $02 / 16 / 89$ & 1.11040 & 1.300 & & \\
\hline 40 & $\begin{array}{l}08 / 22 / 88 \\
05 / 1 / 187\end{array}$ & $\begin{array}{l}1.38280 \\
101500\end{array}$ & 10.080 & & \\
\hline 40 & $05 / 19 / 87$ & $\begin{array}{l}1.01500 \\
0.95000\end{array}$ & 0.216 & & \\
\hline 41 & $06 / 19 / 01$ & $\frac{.95000}{1.36980}$ & 0.690 & 0.2000 & 0.0057 \\
\hline 41 & $01 / 09 / 00$ & 1.37900 & 8.883 & 0.3000 & 0.0057 \\
\hline 41 & $08 / 13 / 00$ & 1.42500 & 9.207 & 0.3600 & 0.0170 \\
\hline 41 & $02 / 17 / 00$ & $\begin{array}{l}1.40800 \\
127000\end{array}$ & $\begin{array}{l}9.003 \\
\end{array}$ & 0.1700 & 0.0 \\
\hline$\frac{41}{41}$ & $\begin{array}{l}08 / 18 / 99 \\
02118999\end{array}$ & $\begin{array}{r}1.37000 \\
1140000\end{array}$ & $\begin{array}{l}9.282 \\
8.816\end{array}$ & $\frac{0.1100}{0.1800}$ & $\begin{array}{l}0.0067 \\
0.0687\end{array}$ \\
\hline 41 & $07 / 19 / 98$ & $\begin{array}{l}1.40000 \\
1.41000\end{array}$ & $\begin{array}{l}.81010 \\
.101\end{array}$ & 0. & 0. \\
\hline 41 & 0 & 13 & 8896 & & \\
\hline 41 & 0 & 1.40 & 9570 & 03000 & 0.0068 \\
\hline 41 & $01 / 01 / 97$ & 1.136340 & $\frac{1.59}{9.169}$ & 0.0500 & 0.0068 \\
\hline 41 & $07 / 26$ & 1.23000 & 4.808 & 0.08 & 0.0110 \\
\hline 41 & $01 / 04 / 96$ & 1.37050 & 9.698 & 0.0100 & 0.0068 \\
\hline 41 & $07 / 06 / 95$ & 1.43380 & 11.361 & 0.4400 & 0.0068 \\
\hline 41 & $02 / 26 / 95$ & 1.38350 & 10.849 & 0.5500 & 0.0068 \\
\hline 41 & $08 / 19 / 94$ & $\begin{array}{l}1.35610 \\
.25000\end{array}$ & 11.705 & 0.2700 & 0.0066 \\
\hline$\frac{41}{41}$ & $\begin{array}{l}10 / 27 / 92 \\
021 / 17 / 92\end{array}$ & $\begin{array}{r}1.35880 \\
1.14900\end{array}$ & $\begin{array}{r}7.790 \\
1030\end{array}$ & & \\
\hline$\frac{41}{41}$ & $\begin{array}{l}02 / 1 / 792 \\
08 / 24 / 91\end{array}$ & $\begin{array}{l}1.441890 \\
1.41420\end{array}$ & $\frac{10.320}{9.360}$ & & \\
\hline 41 & $01 /$ & 13 & 10. & & \\
\hline 41 & 0212190 & 157080 & $\frac{11.303}{11.303}$ & & \\
\hline 41 & $08 / 23 / 89$ & 60 & 11730 & & \\
\hline 41 & & 1.415 & 10.16 & & \\
\hline 41 & $03 / 23 / 87$ & 1.54280 & 11.750 & & \\
\hline 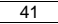 & $09 / 09 / 86$ & 1.07900 & 5.880 & & \\
\hline
\end{tabular}


WSRC-TR-2002-00330, Rev. 0

\begin{tabular}{|c|c|c|c|c|c|c|}
\hline Tank & Date & Density & $\mathrm{Na}(\mathrm{M})$ & $\mathrm{AlOH} 4(\mathrm{M})$ & $\mathrm{C} 204$ (M) & $\mathrm{CrO} 4(\mathrm{M})$ \\
\hline 41 & $\begin{array}{c}\text { ote } \\
04 / 21 / 86\end{array}$ & $\begin{array}{l}1.48620 \\
1.450\end{array}$ & 7.350 & AlU & $0<\mathrm{V}_{4}(\mathrm{I}$ (II) & CIV4 (III) \\
\hline 41 & $08 / 13 / 84$ & 1.23000 & 6.090 & & & \\
\hline 41 & $02 / 26 / 84$ & 1.44000 & 10.350 & & & \\
\hline \begin{tabular}{|l|}
41 \\
41
\end{tabular} & $\begin{array}{l}08 / 09 / 83 \\
04 / 22 / 83\end{array}$ & $\begin{array}{l}1.45000 \\
1.41000\end{array}$ & $\begin{array}{l}8.170 \\
10.710 \\
\end{array}$ & & & \\
\hline $\begin{array}{l}41 \\
41\end{array}$ & $\begin{array}{l}04 / 22 / 83 \\
04 / 22 / 83\end{array}$ & $\begin{array}{l}1.41000 \\
1.49000\end{array}$ & $\begin{array}{l}\frac{10.710}{12.410} \\
\end{array}$ & & & \\
\hline 41 & $04 / 22 / 83$ & 1.49000 & 11.690 & & & \\
\hline 41 & $\begin{array}{l}03 / 09 / 82 \\
\end{array}$ & 1.22000 & 4.700 & & & \\
\hline $\begin{array}{l}42 \\
42\end{array}$ & $08 / 05 / 01$ & $\begin{array}{l}1.27450 \\
131000\end{array}$ & 7.564 & $\begin{array}{l}0.1900 \\
02100\end{array}$ & \begin{tabular}{|l|}
0.0057 \\
\end{tabular} & \\
\hline $\begin{array}{r}42 \\
42 \\
\end{array}$ & $\begin{array}{r}06 / 1 / 4 / 101 \\
0 / 16 / 101\end{array}$ & $\begin{array}{l}1.31900 \\
1.32280\end{array}$ & \begin{tabular}{|l|l|}
8.096 \\
7.887 \\
\end{tabular} & $\begin{array}{l}0.2100 \\
0.2300\end{array}$ & \begin{tabular}{|l|}
0.0018 \\
\end{tabular} & \\
\hline 42 & $03 / 10 / 01$ & $\begin{array}{l}1.02200 \\
1.32200\end{array}$ & 7.123 & $\begin{array}{l}0.2300 \\
0.2700\end{array}$ & $\begin{array}{l}0.0016 \\
0.0034\end{array}$ & \\
\hline 42 & $01 / 09 / 01$ & 1.32000 & 3.625 & 0.0300 & 0.0016 & \\
\hline 42 & 08/09/00 & $\begin{array}{l}1.32000 \\
1.2750\end{array}$ & $\begin{array}{l}7.965 \\
7807 \\
\end{array}$ & 0.2300 & 0.0034 & \\
\hline $\begin{array}{l}42 \\
42\end{array}$ & $\begin{array}{l}02 / 10 / 00 \\
11 / 2 / 2\end{array}$ & $\begin{array}{r}1.32750 \\
135000\end{array}$ & $\begin{array}{l}7.807 \\
.017\end{array}$ & 0.2200 & $\begin{array}{l}0.0034 \\
0069\end{array}$ & \\
\hline $\begin{array}{l}42 \\
42\end{array}$ & $\begin{array}{l}11 / 12 / 2 / 99 \\
09 / 09 / 99\end{array}$ & $\begin{array}{l}1.35000 \\
1.300000\end{array}$ & $\begin{array}{l}8.317 \\
7.139 \\
\end{array}$ & 0.2200 & \begin{tabular}{|l|}
0.0068 \\
0.0200 \\
\end{tabular} & \\
\hline 42 & $06 / 08 / 99$ & 1.00980 & 0.333 & 0.0100 & 0.0015 & \\
\hline 42 & $05 / 07 / 99$ & & 0.191 & 0.0100 & 0.0011 & \\
\hline 42 & $08 / 05 / 98$ & 1.02100 & 0.467 & 0.0100 & 0.0036 & \\
\hline \begin{tabular}{|l|}
42 \\
42
\end{tabular} & $\begin{array}{l}05 / 27 / 98 \\
01 / 13 / 98\end{array}$ & $\begin{array}{l}1.01900 \\
1.00000\end{array}$ & \begin{tabular}{|l|}
0.408 \\
0.448
\end{tabular} & $\begin{array}{l}0.0100 \\
0.030\end{array}$ & $\begin{array}{l}0.0035 \\
0.0030\end{array}$ & \\
\hline $\begin{array}{l}42 \\
42\end{array}$ & $\begin{array}{l}01 / 13 / 98 \\
10 / 27 / 97\end{array}$ & $\begin{array}{l}1.002000 \\
1.02000\end{array}$ & $\begin{array}{l}0.448 \\
0.470 \\
\end{array}$ & $\begin{array}{l}0.0030 \\
0.0040\end{array}$ & $\begin{array}{l}0.0030 \\
0.0040\end{array}$ & \\
\hline 42 & $09 / 23 / 97$ & 1.02000 & 0.440 & 0.0040 & 0.0040 & \\
\hline 42 & $08 / 16 / 97$ & 1.07500 & 0.372 & 0.0100 & 0.0033 & \\
\hline $\begin{array}{l}42 \\
42 \\
\end{array}$ & $\begin{array}{l}06 / 22 / 97 \\
01 / 101 / 97\end{array}$ & $\begin{array}{l}1.01000 \\
1.000000\end{array}$ & \begin{tabular}{|l|l|}
0.259 \\
0.642 \\
\end{tabular} & $\begin{array}{l}0.0100 \\
0.0100\end{array}$ & \begin{tabular}{|l|}
0.0026 \\
0.0076
\end{tabular} & \\
\hline $\begin{array}{l}42 \\
42\end{array}$ & $07 / 29 / 96$ & $\begin{array}{l}1.000000 \\
1.03900\end{array}$ & 0.528 & 0.0100 & $\begin{array}{l}0.0076 \\
0.0078\end{array}$ & \\
\hline 42 & $04 / 30 / 96$ & 1.02630 & 0.527 & 0.0100 & 0.0085 & \\
\hline 42 & $01 / 05 / 96$ & 1.02650 & 0.568 & 0.0100 & 0.0083 & \\
\hline 42 & $11 / 03 / 95$ & $\begin{array}{l}1.02220 \\
1.03230\end{array}$ & $\begin{array}{l}0.504 \\
0545\end{array}$ & 0.0100 & $\begin{array}{l}0.0026 \\
00030\end{array}$ & \\
\hline $\begin{array}{r}42 \\
42 \\
\end{array}$ & $\begin{array}{l}07 / 06 / 95 \\
03 / 107 / 95\end{array}$ & $\begin{array}{r}1.03030 \\
1.02130\end{array}$ & $\begin{array}{l}0.545 \\
0.458 \\
\end{array}$ & $\begin{array}{l}0.0100 \\
0.0100\end{array}$ & \begin{tabular}{|l|}
0.0030 \\
0.0034
\end{tabular} & \\
\hline $\begin{array}{l}42 \\
42 \\
\end{array}$ & $\begin{array}{l}03 / 0 / 95 \\
12 / 18 / 94\end{array}$ & $\begin{array}{l}1.02130130 \\
1.01960\end{array}$ & $\begin{array}{l}0.458 \\
0.466 \\
\end{array}$ & $\begin{array}{l}0.01100 \\
0.0100\end{array}$ & $\begin{array}{l}0.0034 \\
0.0033\end{array}$ & \\
\hline 42 & $09 / 20 / 94$ & 1.01770 & 0.422 & 0.0060 & 0.0032 & \\
\hline 42 & $06 / 15 / 94$ & 1.03000 & 0.315 & & & \\
\hline $\begin{array}{l}42 \\
42\end{array}$ & 06/15/94 & $\begin{array}{l}1.02000 \\
101000\end{array}$ & 0.310 & & & \\
\hline $\begin{array}{r}42 \\
42 \\
\end{array}$ & $\begin{array}{r}06 / 10 / 94 \\
06 / 10 / 94\end{array}$ & $\begin{array}{l}1.01000 \\
1.00000\end{array}$ & $\begin{array}{l}0.300 \\
0.315\end{array}$ & & & \\
\hline 42 & $06 / 04 / 94$ & 1.02000 & 0.316 & & & \\
\hline 42 & $06 / 04 / 94$ & 1.01000 & 0.308 & & & \\
\hline 42 & $05 / 18 / 94$ & 1.08000 & 0.300 & & & \\
\hline $\begin{array}{l}42 \\
42 \\
\end{array}$ & $\begin{array}{l}05 / 18 / 94 \\
05 / 15 / 94\end{array}$ & $\begin{array}{l}1.06000 \\
1.04000\end{array}$ & 0.295 & & & \\
\hline $\begin{array}{l}42 \\
42\end{array}$ & $\begin{array}{l}05 / 151 / 94 \\
05 / 15 / 94\end{array}$ & $\begin{array}{l}1.040000 \\
1.03000\end{array}$ & $\begin{array}{l}0.294 \\
0.287 \\
\end{array}$ & & & \\
\hline 42 & $05 / 16 / 94$ & 1.09000 & 0.746 & & & \\
\hline 42 & $04 / 18 / 94$ & 1.04000 & 0.746 & & & \\
\hline 42 & $02 / 19 / 94$ & $\begin{array}{l}1.04884 \\
10680\end{array}$ & $\begin{array}{l}1.049 \\
1050\end{array}$ & $\begin{array}{l}0.0074 \\
0.0200\end{array}$ & 0.0051 & \\
\hline $\begin{array}{r}42 \\
42 \\
\end{array}$ & $\begin{array}{l}11 / 15 / 93 \\
05 / 27 / 93\end{array}$ & $\begin{array}{l}1.04680 \\
1.04733\end{array}$ & $\begin{array}{l}1.050 \\
1.107\end{array}$ & $\begin{array}{l}0.0200 \\
0.0090\end{array}$ & 000050 & \\
\hline 42 & $\begin{array}{l}05 / 2 / 93 \\
11 / 16 / 92 \\
\end{array}$ & $\begin{array}{l}1.044333 \\
1.04580\end{array}$ & $\begin{array}{l}1.107 \\
0.810\end{array}$ & 0.0090 & & \\
\hline 42 & $10 / 09 / 92$ & 1.06000 & 0.820 & & & \\
\hline 42 & $02 / 17 / 92$ & $\begin{array}{l}1.04520 \\
1.0250\end{array}$ & 0.890 & & & \\
\hline 42 & $\begin{array}{l}08 / 30 / 91 \\
\end{array}$ & $\begin{array}{l}1.04250 \\
102030\end{array}$ & $\begin{array}{l}0.760 \\
\end{array}$ & & & \\
\hline $\begin{array}{l}42 \\
42\end{array}$ & $\begin{array}{l}01 / 26691 \\
08 / 19 / 90\end{array}$ & $\begin{array}{l}1.039330 \\
1.04310\end{array}$ & $\begin{array}{l}0.180 \\
0.750 \\
\end{array}$ & & & \\
\hline 42 & $02 / 20 / 90$ & 1.03400 & 0.610 & & & \\
\hline 42 & $09 / 15 / 89$ & 1.03420 & 0.610 & & & \\
\hline 42 & $09 / 15 / 89$ & 1.04900 & 0.620 & & & \\
\hline \begin{tabular}{|l|}
42 \\
42
\end{tabular} & $\begin{array}{l}08 / 11 / 89 \\
07 / 08 / 89\end{array}$ & $\begin{array}{l}1.02210 \\
1.00060\end{array}$ & $\begin{array}{l}0.410 \\
0.010\end{array}$ & & & \\
\hline $\begin{array}{l}42 \\
42 \\
\end{array}$ & $\begin{array}{l} \\
04 / 24 / 89 \\
\end{array}$ & 1.01900 & 0.740 & & & \\
\hline 42 & $10 / 16 / 88$ & 0.99700 & 0.510 & & & \\
\hline 42 & $06 / 04 / 87$ & 1.00400 & $\begin{array}{l}1.804 \\
\end{array}$ & & & \\
\hline $\begin{array}{r}42 \\
42 \\
4\end{array}$ & $04 / 08 / 87$ & $\begin{array}{l}1.06000 \\
10240\end{array}$ & $\begin{array}{l}1.650 \\
1.730\end{array}$ & & & \\
\hline $\begin{array}{l}42 \\
42\end{array}$ & $\begin{array}{l}12 / 188 / 86 \\
071486\end{array}$ & $\begin{array}{l}1.02240 \\
1.033700\end{array}$ & $\begin{array}{l}1.730 \\
0.584\end{array}$ & & & \\
\hline 42 & $02 / 25 / 86$ & 1.01000 & $\begin{array}{l}0.004 \\
0.039 \\
\end{array}$ & & & \\
\hline 42 & $12 / 29 / 85$ & 1.00800 & 0.026 & & & \\
\hline 42 & $07 / 17 / 85$ & $\begin{array}{l}1.01000 \\
1+1000\end{array}$ & 0.037 & & & \\
\hline 42 & $\begin{array}{l}05 / 22 / 82 \\
05 / 125\end{array}$ & $\begin{array}{l}1.11000 \\
110000\end{array}$ & $\begin{array}{r}2.320 \\
20108 \\
\end{array}$ & 00080 & & \\
\hline $\begin{array}{l}42 \\
42\end{array}$ & $\begin{array}{l}05 / / 155 / 82 \\
03 / 11 / 82\end{array}$ & $\begin{array}{l}1.1 .10000 \\
1.14000\end{array}$ & $\begin{array}{l}2.488 \\
2.230\end{array}$ & 0.0980 & & \\
\hline 43 & $09 / 08 / 01$ & 1.19100 & 4.763 & 0.1400 & 0.0069 & \\
\hline 43 & 09/08/01 & 1.22700 & 5.413 & 0.1400 & 0.0064 & \\
\hline 43 & $09 / 08 / 01$ & $\begin{array}{l}1.22300 \\
12000\end{array}$ & \begin{tabular}{|l|l|}
5.281 \\
5215
\end{tabular} & 0.1000 & 0.0062 & \\
\hline $\begin{array}{r}43 \\
43\end{array}$ & $\begin{array}{c}09 / 08 / 01 \\
\end{array}$ & $\begin{array}{r}1.22000 \\
12000\end{array}$ & $\begin{array}{r}5.315 \\
5338 \\
\end{array}$ & 0.0500 & $\begin{array}{l}0.0065 \\
0.00655\end{array}$ & \\
\hline $\begin{array}{l}43 \\
43\end{array}$ & $\begin{array}{l}09 / 08 / 01 \\
09 / 08 / 01 \\
\end{array}$ & $\begin{array}{r}1.21700 \\
1.22800\end{array}$ & $\begin{array}{l}5.338 \\
5.336 \\
\end{array}$ & $\begin{array}{l}0.0900 \\
0.0200\end{array}$ & $\begin{array}{l}-0.0065 \\
0.0065\end{array}$ & \\
\hline 43 & $07 / 04 / 01$ & $\frac{1.28800}{1.23310}$ & $\begin{array}{l}5.336 \\
5.152\end{array}$ & $\frac{0.0200}{0.1400}$ & $\begin{array}{l}0.00665 \\
0.0064\end{array}$ & \\
\hline 43 & $0501 / 6101$ & 1.20640 & 5676 & 0.1 & 0.0057 & \\
\hline & $03 / 08 / 01$ & 1.20060 & $\begin{array}{l}4.778 \\
478\end{array}$ & 0.0800 & 0.0060 & \\
\hline 43 & $12 / 23300$ & 1.21100 & 4.975 & 0.2700 & 0.0057 & \\
\hline 43 & $10 / 18 / 00$ & 1.20800 & 5.056 & 0.1100 & 0.0057 & \\
\hline 43 & $07 / 30 / 01$ & 1.25000 & 4.919 & 0.2000 & 0.0069 & \\
\hline 43 & $05 / 06 / 00$ & 1.27000 & 5.248 & 0.1200 & 0.0069 & \\
\hline 43 & $02 / 21 / 00$ & 1.17220 & 3.392 & 0 & 0.0068 & \\
\hline 43 & 11/23/99 & $\begin{array}{l}1.26000 \\
120200\end{array}$ & 6.517 & 0.0200 & 0.0 & \\
\hline 43 & $\begin{array}{l}08 / 25 / 99 \\
06 / 01 / 99\end{array}$ & $\begin{array}{r}1.32220 \\
1.24000\end{array}$ & $\begin{array}{l}8.068 \\
5.303 \\
\end{array}$ & $\frac{0.1400}{0.2000}$ & $\begin{array}{l}0.0068 \\
0.0069\end{array}$ & \\
\hline 43 & $03 / 07 / 99$ & $\begin{array}{l}1.24000 \\
1.31000\end{array}$ & $\begin{array}{l}0.303 \\
7.137\end{array}$ & $\begin{array}{l}0.2000 \\
0.0100\end{array}$ & 0.0 & \\
\hline 43 & $11 / 30 / 98$ & 1.20 & 7.117 & 0.0 & 0. & \\
\hline 43 & $08 / 30 / 98$ & 1.19000 & $\begin{array}{l}4.783 \\
\end{array}$ & 0.0600 & 0.0068 & \\
\hline 43 & 05/26/98 & $\begin{array}{l}1.22000 \\
120000\end{array}$ & 5.345 & 0.0700 & 0.0068 & \\
\hline 43 & $\begin{array}{l}021 / 23 / 98 \\
11 / 12 / 97\end{array}$ & $\begin{array}{r}1.20000 \\
1120000\end{array}$ & $\begin{array}{l}4.920 \\
5.603\end{array}$ & $\begin{array}{l}0.1800 \\
0.0600\end{array}$ & $\begin{array}{l}0.00699 \\
0.0069\end{array}$ & \\
\hline 43 & $05 / 09 / 97$ & 121800 & 4.903 & 0.2400 & 0.0069 & \\
\hline 43 & & 12 & 6. & 0.1000 & 0.0068 & \\
\hline 43 & $10 / 06 / 966$ & 118700 & 4040 & 00 & & \\
\hline 43 & $07 / 23 / 96$ & 1.11880 & 3.861 & 0.1100 & 0.0070 & \\
\hline 43 & & 1.19600 & 4.862 & 0.0100 & 0.0 & \\
\hline 43 & 02 & 1.26 & 6.056 & 0.1 & 0.0 & \\
\hline 43 & $10 / 15 / 95$ & 1.40430 & 11.262 & 0.3400 & 0.0068 & \\
\hline 43 & $0 / 718 / 95$ & 1.33740 & 8.443 & 0.2200 & 0.0069 & \\
\hline 43 & $05 / 03 / 95$ & $\begin{array}{l}1.29640 \\
\end{array}$ & 7.591 & 0 & 0.0068 & \\
\hline 年 & 0 & 1.4700 & $\begin{array}{l}0.070 \\
5.422\end{array}$ & 0.0000 & 0.0003 & \\
\hline 43 & 07/14/94 & 1.38990 & $\begin{array}{l}0.4<2 \\
13.250\end{array}$ & 0.14600 & $\begin{array}{l}.00044 \\
0.0068\end{array}$ & \\
\hline
\end{tabular}


WSRC-TR-2002-00330, Rev. 0

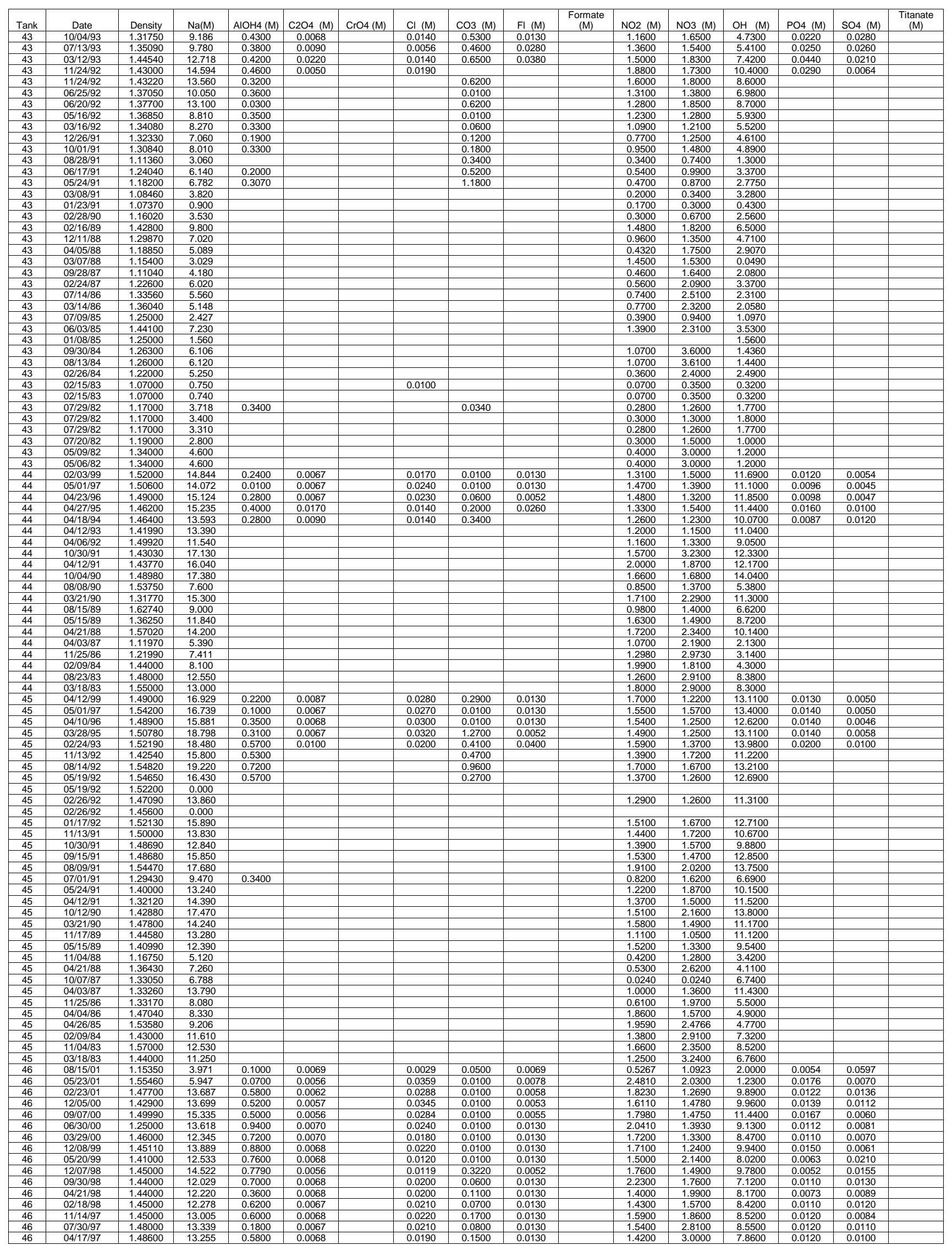


WSRC-TR-2002-00330, Rev. 0

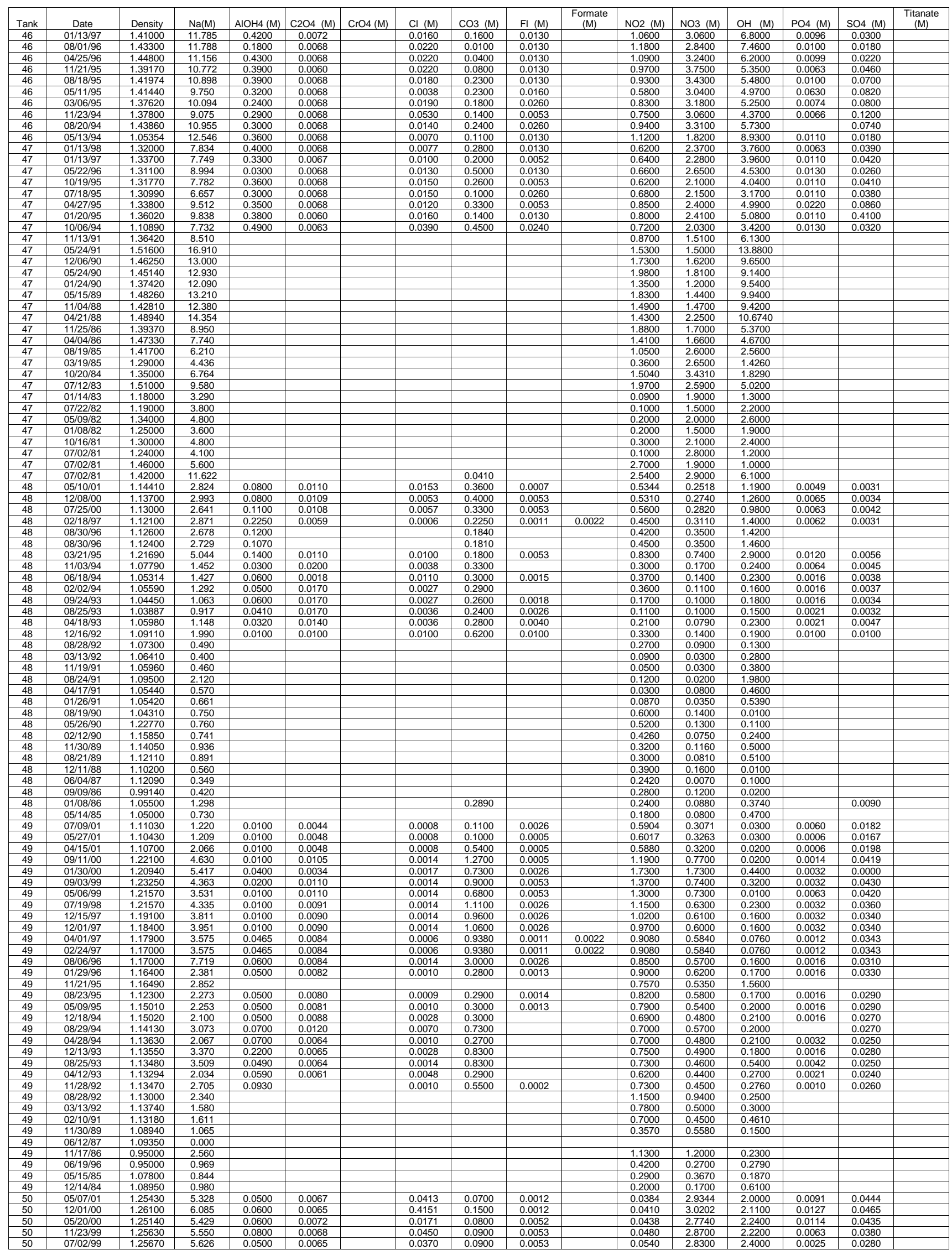


WSRC-TR-2002-00330, Rev. 0

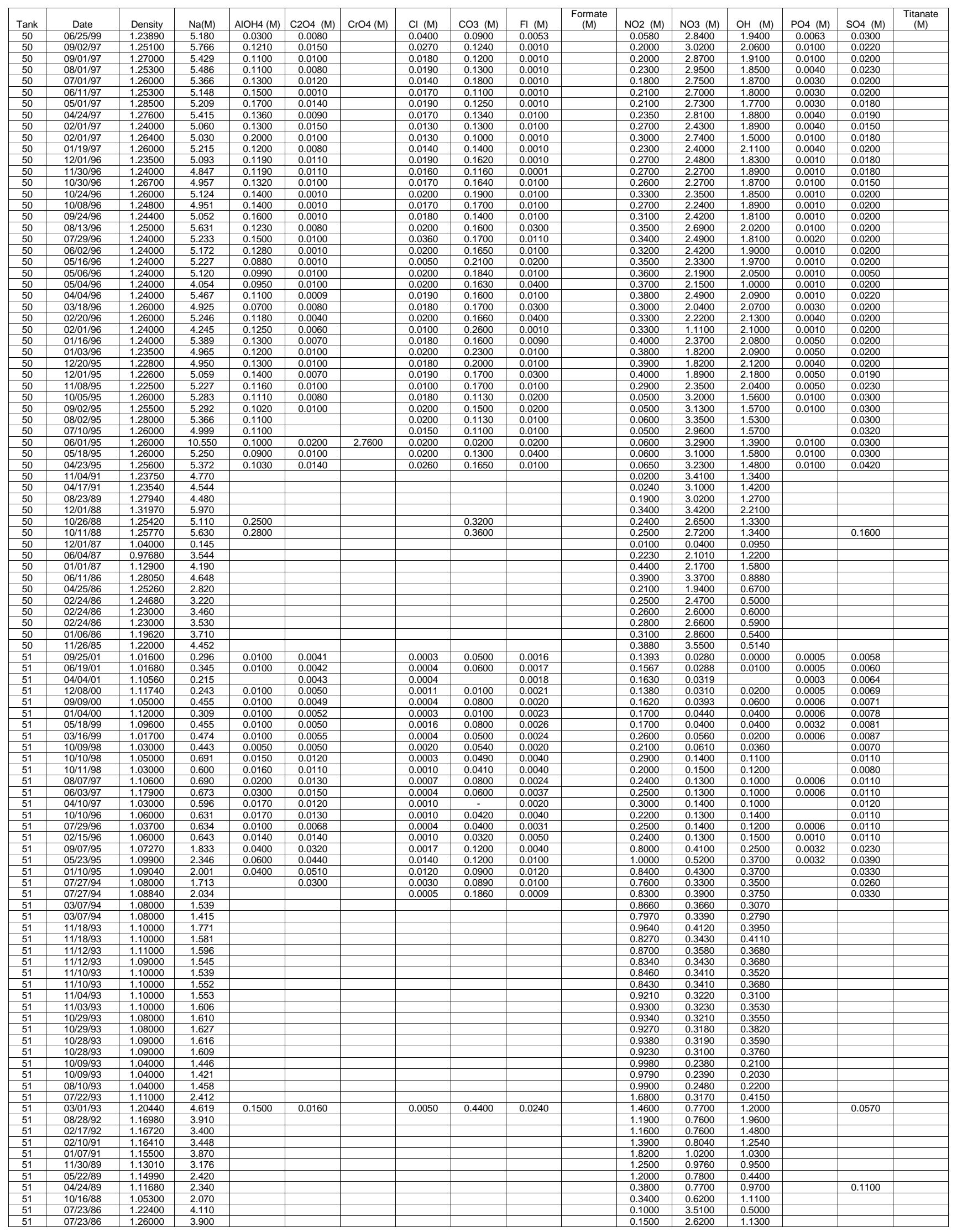


WSRC-TR-2002-00330, Rev. 0

This page intentionally left blank. 


\section{APPENDIX B}

\section{MODIFICATIONS TO GEOCHEMIST'S WORKBENCH FOR NAS gel}

The Geochemist's Workbench (GWB) software package uses equilibrium constants to calculate mineral saturation. For the previous evaporator reports, ${ }^{3,4,5}$ the equilibrium constants used for sodium aluminosilicate gel (NAS $\mathrm{Nel}_{\text {gel }}$ ), the precursor for undesirable minerals in the SRS evaporators, were based on an extrapolation of solubility data in nominally $4 \mathrm{M}$ sodium solutions at temperatures of 30 and $50^{\circ} \mathrm{C}$. ${ }^{6}$ To better model the solubility of $\mathrm{NAS}_{\text {gel }}$ at SRS evaporator sodium concentrations (nominally $8.5 \mathrm{M}$ ), Jonas Adai-Mensah of the University of South Australia measured $\mathrm{NAS}_{\text {gel }}$ solubility at a variety of solution conditions and temperatures. ${ }^{8}$ These results were then used to calculate equilibrium constants for input into the GWB database. An outline of the methodology follows.

1. Add data for $\mathrm{NAS}_{\text {gel }}$ to the thermodynamic database. Data includes the molecular weight, molecular formula, decomposition reaction using GWB basis species, and the log of the decomposition reaction equilibrium constant $(\mathrm{K})$ at $0,25,60,100,150,200,250$, and $300^{\circ} \mathrm{C}$. At this step all $\log \mathrm{K}$ values are set to zero.

2. Run the React.exe module of GWB with the experimentally determined solution compositions and temperatures to calculate $\log \mathrm{K}$ for each solution and temperature ${ }^{2}$.

3. Fit a model of the calculated $\log \mathrm{K}$ values as a function of solution composition and temperature.

4. Using the model, calculate $\log \mathrm{K}$ for the composition $8.5 \mathrm{~m} \mathrm{Na}^{+}, 3 \mathrm{~m} \mathrm{NO}_{2}{ }^{-}+\mathrm{NO}_{3}{ }^{-}$, and $0.2 \mathrm{~m}$ $\mathrm{Al}(\mathrm{OH})_{4}{ }^{-}$at the following temperatures: $0,25,60,100,150,200,250$, and $300^{\circ} \mathrm{C}$.

5. Enter the calculated $\log \mathrm{K}$ values in the database

The molecular formula for $\mathrm{NAS}_{\mathrm{gel}}$, as determined by Mensah, is given in Equation B-1. This equation also shows the decomposition of $\mathrm{NAS}_{\text {gel }}$ in terms of GWB basis species ${ }^{3}$.

$$
\mathrm{Na}_{12} \mathrm{Al}_{12} \mathrm{Si}_{12} \mathrm{O}_{48} \cdot 27 \mathrm{H}_{2} \mathrm{O}+48 \mathrm{H}^{+} \longleftrightarrow 12 \mathrm{Na}^{+}+12 \mathrm{Al}^{3+}+12 \mathrm{SiO}_{2}(\mathrm{aq})+51 \mathrm{H}_{2} \mathrm{O}
$$

In the Mensah experiments, $\mathrm{NAS}_{\text {gel }}$ was dissolved in solutions of known compositions and known temperatures (see Table B-1). When the decomposition reaction was at equilibrium ${ }^{4}$, silicon and aluminum concentrations were measured. Based on the starting solution composition and the measured silicon and aluminum concentrations, the equilibrium solution compositions were calculated as follows:

2 At saturation, $\log \mathrm{Q} / \mathrm{K}=0(\log \mathrm{Q}=\log \mathrm{K})$. With $\log \mathrm{K}$ set to zero, at saturation, the reaction quotient, $\mathrm{Q}$, as calculated by React.exe is equal to $\mathrm{K}$ or $\log \mathrm{Q}=\log \mathrm{K}$.

3 The actual species that are involved in the reaction (e.g., $\left.\mathrm{Al}(\mathrm{OH})_{4}{ }^{-}\right)$are swapped for basis species when running components of GWB.

4 Solutions were periodically sampled and analyzed to determine when equilibrium was reached (see Ref 8 for details). 
- $\left(\mathrm{Na}^{+}\right)$was increased based on the measured silicon concentration, since, per Equation B-1, for each mole of silicon formed, one mole of $\mathrm{Na}^{+}$is formed.

- Silicon is assumed to be in the form $\mathrm{H}_{2} \mathrm{SiO}_{4}{ }^{2-}$.

- Aluminum is assumed to be in the form of $\mathrm{Al}(\mathrm{OH})_{4}{ }^{-}$

- Hydroxide is calculated from a charge balance:

$$
\left(\mathrm{OH}^{-}\right)=\left(\mathrm{Na}^{+}\right)-\left(\mathrm{NO}_{3}{ }^{-}\right)-\left(\mathrm{NO}_{2}{ }^{-}\right)-\left(\mathrm{Al}(\mathrm{OH})_{4}{ }^{-}\right)-2 \cdot\left(\mathrm{H}_{2} \mathrm{SiO}_{4}{ }^{2-}\right)
$$

The calculated equilibrium solution compositions are given in Table B-2.

Table B-6. Initial Solution Composition and Equilibrium Aluminum and Silicon Compositions for $\mathrm{NAS}_{\mathrm{gel}}$ Solubility Experiments

\begin{tabular}{|c|c|c|c|c|c|c|c|}
\hline \multirow{2}{*}{$\begin{array}{l}\text { Solution } \\
\text { ID }\end{array}$} & \multicolumn{5}{|c|}{ Initial Solution Composition } & \multicolumn{2}{|c|}{ Equilibrium Solubility } \\
\hline & $\left(\mathrm{Na}^{+}\right)$ & $\left(\mathbf{O H}^{-}\right)$ & $\left(\mathrm{NO}_{3}{ }^{-}\right)$ & $\left(\mathrm{NO}_{2}^{-}\right)$ & $(\mathrm{Al}(\mathrm{III}))$ & $(\mathrm{Si})$ & (AI) \\
\hline \multicolumn{8}{|c|}{$\mathrm{T}=30^{\circ} \mathrm{C}$} \\
\hline NAS-1 & 3 & 3 & 0 & 0 & 0 & 0.0702 & 0.0791 \\
\hline NAS-2 & 6 & 6 & 0 & 0 & 0 & 0.1013 & 0.0989 \\
\hline NAS-3 & 6 & 4 & 1 & 1 & 0 & 0.0861 & 0.0791 \\
\hline NAS-4 & 6 & 4 & 1 & 1 & 0.15 & 0.0558 & 0.1941 \\
\hline NAS-5 & 6 & 4 & 1 & 1 & 0.45 & 0.0398 & 0.4703 \\
\hline NAS-6 & 12 & 8 & 2 & 2 & 0 & 0.1088 & 0.1091 \\
\hline NAS-7 & 12 & 8 & 2 & 2 & 0.15 & 0.0852 & 0.2201 \\
\hline NAS-8 & 12 & 8 & 2 & 2 & 0.45 & 0.0564 & 0.5104 \\
\hline \multicolumn{8}{|c|}{$\mathrm{T}=65^{\circ} \mathrm{C}$} \\
\hline NAS-9 & 3 & 3 & 0 & 0 & 0 & 0.0881 & 0.1049 \\
\hline NAS-10 & 6 & 6 & 0 & 0 & 0 & 0.2074 & 0.2061 \\
\hline NAS-11 & 6 & 4 & 1 & 1 & 0 & 0.1163 & 0.125 \\
\hline NAS-12 & 6 & 4 & 1 & 1 & 0.15 & 0.0705 & 0.2052 \\
\hline NAS-13 & 6 & 4 & 1 & 1 & 0.45 & 0.0454 & 0.5083 \\
\hline NAS-14 & 12 & 8 & 2 & 2 & 0 & 0.2578 & 0.2842 \\
\hline NAS-15 & 12 & 8 & 2 & 2 & 0.15 & 0.1937 & 0.3508 \\
\hline NAS-16 & 12 & 8 & 2 & 2 & 0.45 & 0.1447 & 0.5796 \\
\hline \multicolumn{8}{|c|}{$\mathrm{T}=130^{\circ} \mathrm{C}$} \\
\hline NAS-17 & 3 & 3 & 0 & 0 & 0 & 0.1119 & 0.1132 \\
\hline NAS-18 & 6 & 6 & 0 & 0 & 0 & 0.2934 & 0.2952 \\
\hline NAS-19 & 6 & 4 & 1 & 1 & 0 & 0.1565 & 0.1589 \\
\hline NAS-20 & 6 & 4 & 1 & 1 & 0.15 & 0.0892 & 0.2282 \\
\hline NAS-21 & 6 & 4 & 1 & 1 & 0.45 & 0.0576 & 0.5108 \\
\hline
\end{tabular}


WSRC-TR-2002-00330, Rev. 0

Table B-7. Molar NAS gel $_{\text {Equilibrium Compositions }}$

\begin{tabular}{|c|c|c|c|c|c|c|}
\hline Solution ID & $\left(\mathrm{Na}^{+}\right)$ & $\left(\mathrm{OH}^{-}\right)$ & $\left(\mathrm{NO}_{3}^{-}\right)$ & $\left(\mathrm{NO}_{2}^{-}\right)$ & $\left(\mathrm{H}_{2} \mathrm{SiO}_{4}{ }^{2-}\right)$ & $\left(\mathrm{Al}(\mathrm{OH})_{4}^{-}\right)$ \\
\hline \multicolumn{7}{|c|}{$\mathrm{T}=30^{\circ} \mathrm{C}$} \\
\hline NAS-1 & 3.0702 & 2.8507 & 0 & 0 & 0.0702 & 0.0791 \\
\hline NAS-2 & 6.1013 & 5.7998 & 0 & 0 & 0.1013 & 0.0989 \\
\hline NAS-3 & 6.0861 & 3.8348 & 1 & 1 & 0.0861 & 0.0791 \\
\hline NAS-4 & 6.0558 & 3.7501 & 1 & 1 & 0.0558 & 0.1941 \\
\hline NAS-5 & 6.0398 & 3.4899 & 1 & 1 & 0.0398 & 0.4703 \\
\hline NAS-6 & 12.1088 & 7.7821 & 2 & 2 & 0.1088 & 0.1091 \\
\hline NAS-7 & 12.0852 & 7.6947 & 2 & 2 & 0.0852 & 0.2201 \\
\hline NAS-8 & 12.0564 & 7.4332 & 2 & 2 & 0.0564 & 0.5104 \\
\hline \multicolumn{7}{|c|}{$\mathrm{T}=65^{\circ} \mathrm{C}$} \\
\hline NAS-9 & 3.0881 & 2.807 & 0 & 0 & 0.0881 & 0.1049 \\
\hline NAS-10 & 6.2074 & 5.5865 & 0 & 0 & 0.2074 & 0.2061 \\
\hline NAS-11 & 6.1163 & 3.7587 & 1 & 1 & 0.1163 & 0.125 \\
\hline NAS-12 & 6.0705 & 3.7243 & 1 & 1 & 0.0705 & 0.2052 \\
\hline NAS-13 & 6.0454 & 3.4463 & 1 & 1 & 0.0454 & 0.5083 \\
\hline NAS-14 & 12.2578 & 7.458 & 2 & 2 & 0.2578 & 0.2842 \\
\hline NAS-15 & 12.1937 & 7.4555 & 2 & 2 & 0.1937 & 0.3508 \\
\hline NAS-16 & 12.1447 & 7.2757 & 2 & 2 & 0.1447 & 0.5796 \\
\hline \multicolumn{7}{|c|}{$\mathrm{T}=130^{\circ} \mathrm{C}$} \\
\hline NAS-17 & 3.1119 & 2.7749 & 0 & 0 & 0.1119 & 0.1132 \\
\hline NAS-18 & 6.2934 & 5.4114 & 0 & 0 & 0.2934 & 0.2952 \\
\hline NAS-19 & 6.1565 & 3.6846 & 1 & 1 & 0.1565 & 0.1589 \\
\hline NAS-20 & 6.0892 & 3.6826 & 1 & 1 & 0.0892 & 0.2282 \\
\hline NAS-21 & 6.0576 & 3.4316 & 1 & 1 & 0.0576 & 0.5108 \\
\hline
\end{tabular}

For input into React.exe of GWB, the molarities must now be converted to molalities.

$$
[X]=(X) \cdot\left(\frac{1}{\text { density }- \text { solute mass }}\right)
$$

where

$[\mathrm{X}]=$ molality of component $\mathrm{X}$

$(\mathrm{X})=$ molarity of component $\mathrm{X}$

density $=$ solution density in $\mathrm{kg} / \mathrm{L}$

solute mass $=$ mass in $\mathrm{kg}$ of solute in $1 \mathrm{~L}$ of solution

The density is calculated from Equation B-3. The derivation of this correlation can be found in Appendix A of this document.

$$
\text { density }=1.013+5.701 \cdot 10^{-2} \cdot\left(\mathrm{Na}^{+}\right)-1.725 \cdot 10^{-3} \cdot\left(\mathrm{Na}^{+}\right)^{2}
$$




$$
\text { solute mass }=\frac{1}{1000} \sum\left(X_{i}\right) M W_{i}
$$

Table B-3 shows the results of the conversion of equilibrium molar concentrations to equilibrium molal concentrations.

The compositions and temperatures given in Table B-3 were input into React.exe of GWB. The calculated $\log \mathrm{K}$ values are given in Table B-4.

Table B-8. Calculated Solution Density, Solute Mass, and Composition in Molality for NAS gel Equilibrium Solutions

\begin{tabular}{|c|c|c|c|c|c|c|c|}
\hline Solution ID & $\begin{array}{c}\text { Solution } \\
\text { Density } \\
\text { (kg/L) }\end{array}$ & $\begin{array}{c}\text { Solute } \\
\text { Mass }(\mathrm{kg} / \mathrm{L})\end{array}$ & {$\left[\mathrm{Na}^{+}\right]$} & {$\left[\mathrm{OH}^{-}\right]$} & {$\left[\mathrm{NO}_{2}^{-}+\mathrm{NO}_{3}^{-}\right]$} & {$\left[\mathrm{H}_{2} \mathrm{SiO}_{4}{ }^{2-}\right]$} & {$\left[\mathrm{Al}(\mathrm{OH})_{4}^{-}\right]$} \\
\hline \multicolumn{8}{|c|}{$\mathrm{T}=30^{\circ} \mathrm{C}$} \\
\hline NAS-1 & 1.117 & 0.133 & 3.121 & 2.898 & 0.000 & 0.0714 & 0.0804 \\
\hline NAS-2 & 1.219 & 0.258 & 6.350 & 6.036 & 0.000 & 0.1054 & 0.1029 \\
\hline NAS-3 & 1.246 & 0.329 & 6.634 & 4.180 & 2.180 & 0.0939 & 0.0862 \\
\hline NAS-4 & 1.246 & 0.335 & 6.646 & 4.115 & 2.195 & 0.0612 & 0.2130 \\
\hline NAS-5 & 1.249 & 0.355 & 6.754 & 3.903 & 2.236 & 0.0445 & 0.5259 \\
\hline NAS-6 & 1.476 & 0.647 & 14.618 & 9.395 & 4.829 & 0.1313 & 0.1317 \\
\hline NAS-7 & 1.476 & 0.654 & 14.699 & 9.359 & 4.865 & 0.1036 & 0.2677 \\
\hline NAS-8 & 1.478 & 0.673 & 14.981 & 9.236 & 4.970 & 0.0701 & 0.6342 \\
\hline \multicolumn{8}{|c|}{$\mathrm{T}=65^{\circ} \mathrm{C}$} \\
\hline NAS-9 & 1.118 & 0.137 & 3.146 & 2.860 & 0.000 & 0.0898 & 0.1069 \\
\hline NAS-10 & 1.227 & 0.277 & 6.534 & 5.880 & 0.000 & 0.2183 & 0.2169 \\
\hline NAS-11 & 1.249 & 0.335 & 6.697 & 4.115 & 2.190 & 0.1273 & 0.1369 \\
\hline NAS-12 & 1.247 & 0.337 & 6.671 & 4.093 & 2.198 & 0.0775 & 0.2255 \\
\hline NAS-13 & 1.250 & 0.358 & 6.780 & 3.865 & 2.243 & 0.0509 & 0.5701 \\
\hline NAS-14 & 1.487 & 0.676 & 15.105 & 9.190 & 4.929 & 0.3177 & 0.3502 \\
\hline NAS-15 & 1.484 & 0.675 & 15.059 & 9.208 & 4.940 & 0.2392 & 0.4332 \\
\hline NAS-16 & 1.485 & 0.688 & 15.238 & 9.129 & 5.019 & 0.1816 & 0.7272 \\
\hline \multicolumn{8}{|c|}{$\mathrm{T}=130^{\circ} \mathrm{C}$} \\
\hline NAS-17 & 1.120 & 0.140 & 3.175 & 2.831 & 0.000 & 0.1142 & 0.1155 \\
\hline NAS-18 & 1.233 & 0.292 & 6.688 & 5.750 & 0.000 & 0.3118 & 0.3137 \\
\hline NAS-19 & 1.252 & 0.342 & 6.768 & 4.051 & 2.199 & 0.1720 & 0.1747 \\
\hline NAS-20 & 1.249 & 0.341 & 6.708 & 4.057 & 2.203 & 0.0983 & 0.2514 \\
\hline NAS-21 & 1.251 & 0.360 & 6.799 & 3.851 & 2.245 & 0.0646 & 0.5733 \\
\hline
\end{tabular}


WSRC-TR-2002-00330, Rev. 0

Table B-9. Calculated log K Values for NAS gel Solutions

\begin{tabular}{|l|c|}
\hline Solution ID & \multicolumn{1}{|c|}{$\log$ K } \\
\hline NAS-1 & 157.7136 \\
\hline NAS-2 & 158.0517 \\
\hline NAS-3 & 161.6694 \\
\hline NAS-4 & 164.4053 \\
\hline NAS-5 & 168.2868 \\
\hline NAS-6 & 164.4158 \\
\hline NAS-7 & 167.0295 \\
\hline NAS-8 & 169.9796 \\
\hline NAS-9 & 135.4874 \\
\hline NAS-10 & 141.3506 \\
\hline NAS-11 & 140.6694 \\
\hline NAS-12 & 140.7778 \\
\hline NAS-13 & 144.2983 \\
\hline NAS-14 & 149.3309 \\
\hline NAS-15 & 148.9351 \\
\hline NAS-16 & 150.5189 \\
\hline NAS-17 & 114.779 \\
\hline NAS-18 & 122.9535 \\
\hline NAS-19 & 120.7002 \\
\hline NAS-20 & 119.6384 \\
\hline NAS-21 & 122.5377 \\
\hline
\end{tabular}

The statistical software $\mathrm{JMP}^{\circledR}$ was used to fit a model of $\log \mathrm{K}$ as a function of $\left[\mathrm{Na}^{+}\right],\left[\mathrm{Al}(\mathrm{OH})_{4}{ }^{-}\right]$, and the inverse of the temperature in Kelvin.

Sodium was chosen because it is the major component of the solutions. Aluminate was chosen because, when added to a starting solution, it had a major impact on solubility. The inverse temperature was chosen because the log of an equilibrium constant is typically proportional to the inverse temperature. Nitrate and nitrite were not used because they had little direct impact on solubility. Hydroxide was not chosen because it is calculated from a charge balance, and highly correlated to the sodium concentration.

The resulting model is given in the following equation.

$$
\begin{gathered}
\log \mathrm{K}=9.125 \cdot \log [\mathrm{Na}+]+7.003 \cdot \log \left[\mathrm{Al}(\mathrm{OH})_{4}{ }^{-}\right]+\frac{5.277 \cdot 10^{4}}{T}-14.54 \\
\mathrm{R}^{2}=0.99
\end{gathered}
$$

Using the above model (Equation B-5), $\log \mathrm{K}$ values were calculated at $8.5 \mathrm{~m} \mathrm{Na}^{+}, 0.2 \mathrm{~m}$ $\mathrm{Al}(\mathrm{OH})_{4}{ }^{-}$, and the following temperatures: $0,25,60,100,150,200,250$, and $300^{\circ} \mathrm{C}$. Table B-4 lists the $\log \mathrm{K}$ values calculated using Equation B-5. These values were then input into the GWB thermodynamic database. 
WSRC-TR-2002-00330, Rev. 0

Table B-10. NAS gel $\log$ K Values for Input into GWB Thermodynamic Database

\begin{tabular}{|c|c|}
\hline $\begin{array}{c}\text { Temperature } \\
\left({ }^{\circ} \mathrm{C}\right)\end{array}$ & $\log \mathrm{K}$ \\
\hline 0 & 182.3431 \\
\hline 25 & 166.1269 \\
\hline 60 & 147.5148 \\
\hline 100 & 130.5209 \\
\hline 150 & 113.7981 \\
\hline 200 & 100.6108 \\
\hline 250 & 89.9449 \\
\hline 300 & 81.1405 \\
\hline
\end{tabular}

Figure B-1 shows a comparison between the log K values derived from Ejaz solubility data (see Evaporator Report Part I) ${ }^{3}$ and values derived from the Mensah data.

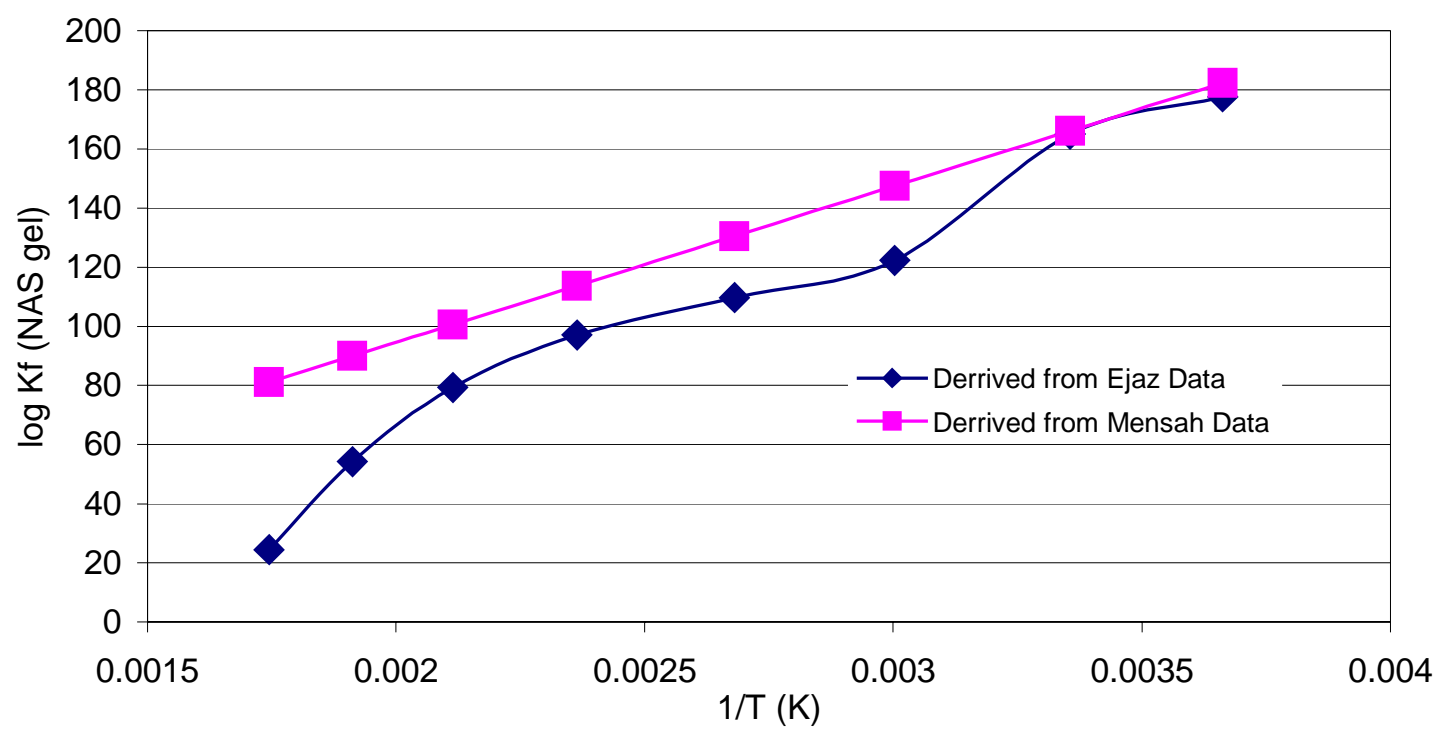

Figure B-3. Comparison of log K Values Used in GWB

From Figure B-1, it can be seen that the Mensah data predicts higher solubilities than the Ejaz solubility data. This is shown more graphically in Figure B-2. In this figure, calculated $\log Q / K$ values (using React.exe of GWB) are plotted for the solutions given in Table B-3. Because these solutions are saturated, their $\log \mathrm{Q} / \mathrm{K}$ values are, by definition, zero. However, in all cases, using the Ejaz derived $\log \mathrm{K}$ values, the calculated $\log \mathrm{Q} / \mathrm{K}$ is much greater than zero. Using the Mensah derived $\log \mathrm{K}$ values, there is an almost even scattering about $\log \mathrm{Q} / \mathrm{K}=0$. Thus, based on the Mensah solutions, using the Ejaz derived $\log \mathrm{K}$ values tends to over estimate the saturation of these solutions relative to $\mathrm{NAS}_{\mathrm{gel}}$. 
WSRC-TR-2002-00330, Rev. 0

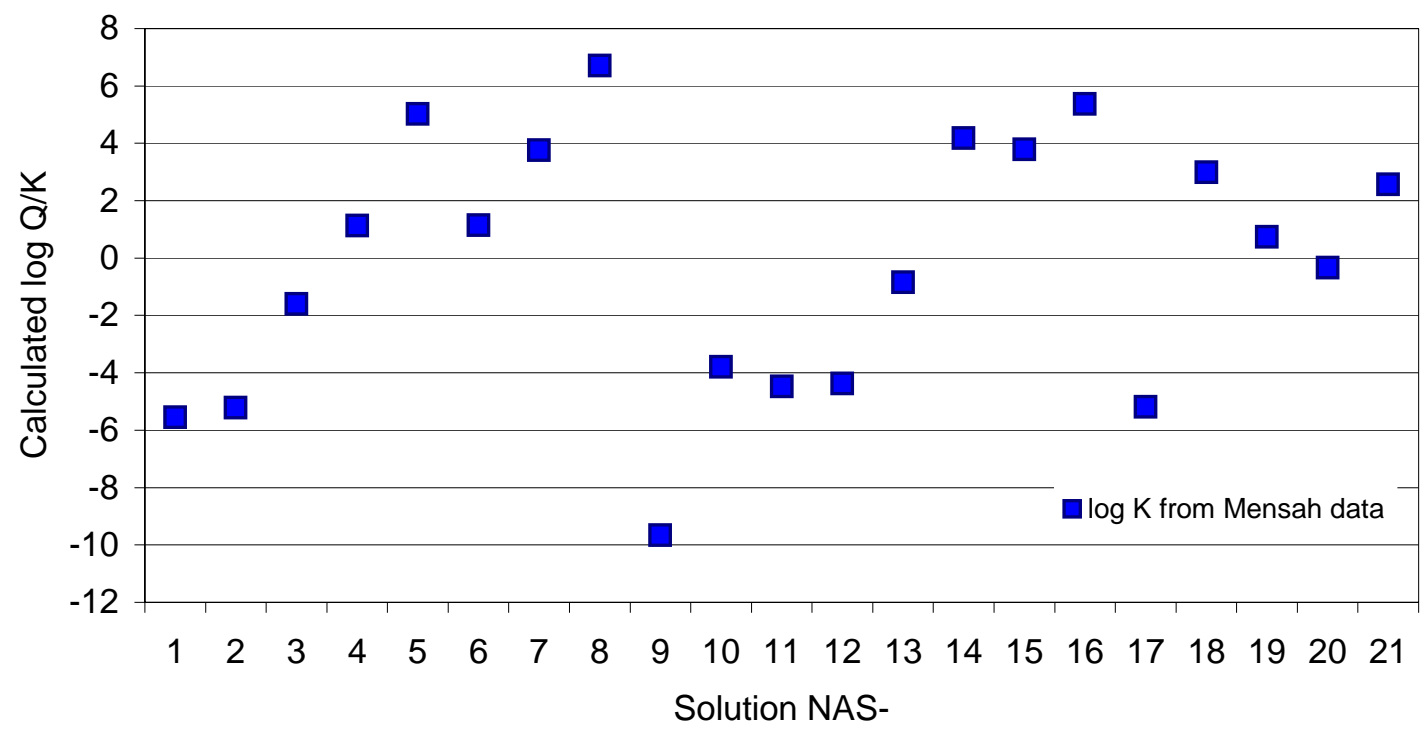

(a)

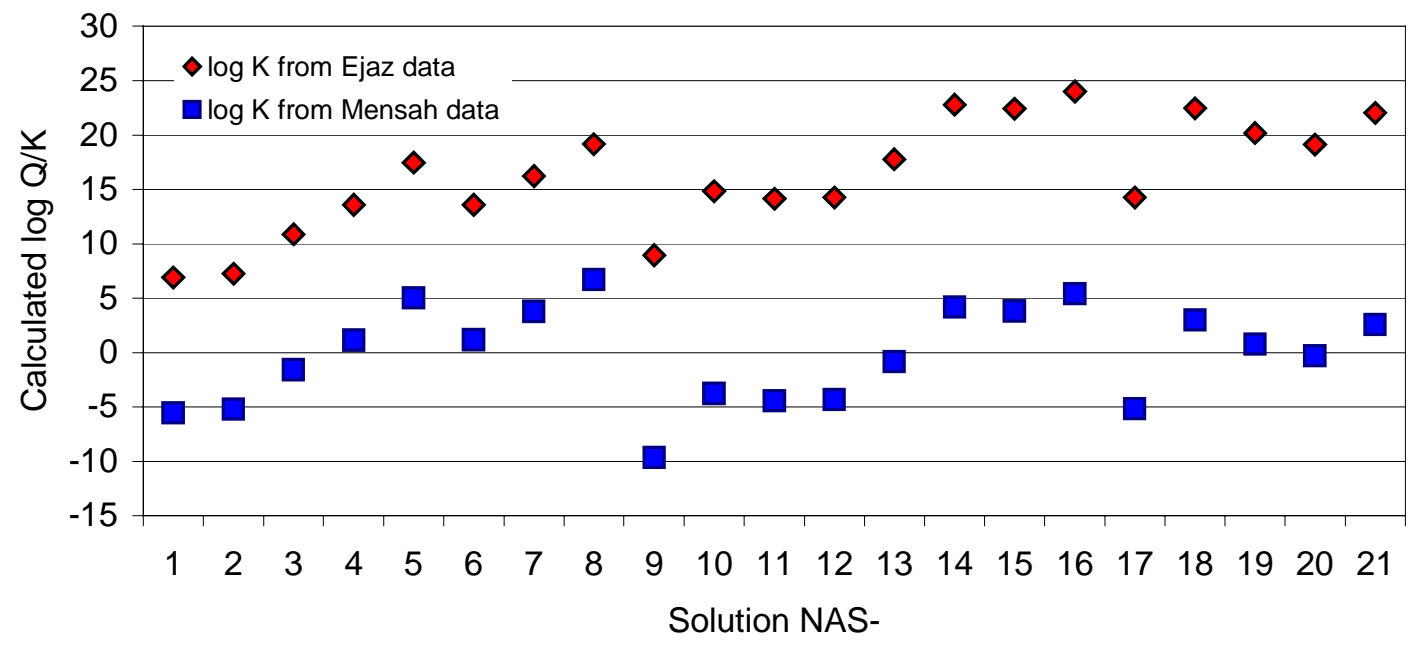

(b)

Figure B-4. Calculated $\log \mathrm{Q} / \mathrm{K}$ values for Mensah $\mathrm{NAS}_{\mathrm{gel}}$ Saturated Solutions 
WSRC-TR-2002-00330, Rev. 0

This page intentionally left blank. 
WSRC-TR-2002-00330, Rev. 0

\section{REFERENCES}

1 W. R. Wilmarth, C. J. Coleman, A. R. Jurgensen, W. M. Smith, J. C. Hart, W. T. Boyce, D. Missimer, C. M. Conley, "Characterization and Dissolution Studies of Samples from the 242-16H Evaporator,” WSRC-TR-2000-00038, Rev. 0 (January 31, 2000).

2 W. R. Wilmarth, C. J. Coleman, J. C. Hart, and W. T. Boyce, "Characterization of Samples from the 242-16H Evaporator Wall,” WSRC-TR-2000-00089 (March 20, 2000).

3 C.M. Jantzen, J.E. Laurinat, and K.G. Brown "Thermodynamic Modeling of the SRS Evaporators: Part I. The 2H and 2F Systems (U)," WSRC-TR-2000-00293, Rev. 1 (April 4, 2002).

4 C.M. Jantzen, J.E. Laurinat, and K.G. Brown "Thermodynamic Modeling of the SRS Evaporators: Part II. The 3H System (U),’ WSRC-TR-2001-00155, Rev. 1 (April 8, 2002).

5 C.M. Jantzen, K.G. Brown, T.B. Edwards, and J.M. Pareizs, "Thermodynamic Modeling of the SRS Evaporators: Part III. Temperature, Evaporation, and Composition Effects on Process Control Strategy," WSRC-TR-2002-00318, Rev. 0 (July 23, 2002).

6 T. Ejaz A.G. Jones and P. Graham, "Solubility of Zeolite-A and Its Amorphous Precursor Under Synthesis Conditions,’ J. Chem. Eng. Data, 44, 574-576 (1999).

7 H. A. Gasteiger, W. J. Frederick, and R. C. Streisel, "Solubility of Aluminosilicates in Alkaline Solutions and a Thermodynamic Equilibrium Model,’ Ind. Eng. Chem. Res., 31, 1183-1190 (1992).

8 J. Adai-Mensah, J.Li, M. Zbik, “The Chemistry, Crystallization, Physicochemical Properties, and Behavior of Sodium Aluminosilicate Solid Phases,' SRT-LWP-200200060 (June 7, 2002).

9 J.M. Pareizs and C.M. Jantzen, "Thermodynamic Modeling of the SRS Evaporators: Part V. Validation,” WSRC-TR-2002-00331 (September 20, 2002).

10 W. R. Wilmarth, S. D. Fink, D. T. Hobbs, M. S. Hay, “Characterization and Dissolution Studies of Samples from the 242-16H Evaporator Gravity Drain Line," WSRC-TR-97-0326, Rev.0 (October 16, 1997).

11 C.S. Boley, M.C. Thompson, W.R. Wilmarth, and K.G. Brown, "Technical Basis for the 242-16H Evaporator Cleaning Process,” WSRC-TR-2000-00211, Rev. 1 (November, 2000). 
WSRC-TR-2002-00330, Rev. 0

12 Iman, R. L. and J. C. Helton, “An Investigation of Uncertainty and Sensitivity Analysis Techniques for Computer Models,” Risk Analysis, 8, 71-90, 1988.

13 Sacks, J., S. B. Schiller, and W. J. Welch, "Designs for Computer Experiments," Technometrics, 31, 41-47,1989.

14 Sacks, J., W. J. Welch, T. J. Mitchell, and H. P. Wynn, "Design and Analysis of Computer Experiments,” Statistical Science, 4, 409-435, 1989.

15 Ye, K. Q., “Orthogonal Column Latin Hypercubes and Their Application in Computer Experiments," Journal of the American Statistical Association, 93, 14301439, 1998.

16 K.G. Brown, "Designed SRS Evaporator Experiments Using Geochemist's Workbench,” SRTC-GPD-2002-00058 (May 15, 2002).

17 R.M. Barrer, "Hydrothermal Chemistry of Zeolites," Academic Press,London (1982).

18 The American Heritage Dictionary, Second College Edition, Houghton Mifflin Co., Boston, MA, (1982).

19 G.M. Barrow, “Physical Chemistry,” 2nd edition, McGraw-Hill Book Company, New York, 843pp., (1966).

20 M.C. Barnes, J.A. Mensah, and A.R. Gerson, "The Mechanism of the Sodalite-toCancrinite Phase Transformation in Synthetic Spent Bayer Liquor,' Microporous and Mesoporous Materials, 31, 287-302 (1999).

21 A.R. Gerson and K. Zheng, "Bayer Process Plant Scale: Transformation of Sodalite to Cancrinite,' J. of Crystal Growth, 171, 209-218 (1997).

22 R. M. Barrer, J. W. Baynham, F. W. Bultitude, and W. M. Meier, "Hydrothermal Chemistry of the Silicates. Part V23I, Low-Temperature Crystal Growth of Aluminosilicates, and of Some Gallium and Germanium Analogues," 195-208 (1959).

23 J.C. Buh. And J. Lons, "Synthesis and Crystal Structure of Nitrate Enclathrated Sodalite, $\mathbf{N a}_{\mathbf{8}}\left[\mathrm{AlSiO}_{4}\right]_{6}\left(\mathbf{N O}_{3}\right)_{2}$," Journal of Alloys and Compounds, v.235, 41-47 (1996).

24 W. R. Wilmarth, D. D. Walker, S. D. Fink, "Sodium Aluminosilicate Formation in Tank 43H Simulants,’ WSRC-TR-97-00389, Rev. 0 (November 15, 1997).

25 B. Subotic, D. Skrtic, I. Smit, L. Sekovanic, “Transformation of Zeolite-A into Hydroxysodalite,” J. Crystal Growth, 50, 498-508 (1980). 
WSRC-TR-2002-00330, Rev. 0

26 S. Bosnar and B. Subotic, "Mechanism and Kinetics of the Growth of Zeolite Microcrystals; Part I. Influence of the Alkalinity of the System on the Growth of Zeolite-A Microcrystals," Microporous and Misoporous Materials, 28, 483-493 (1999).

27 R.K. Iler, "The Colloid Chemistry of Silica and Silicates," Cornell University Press, Ithaca, NY, 324pp. (1955).

28 A.K. Varshneya, "Fundamentals of Inorganic Glasses," Academic Press, Inc., New York, 570pp. (1994).

29 A.J. Mattus, C.H. Mattus, and R.D. Hunt, "Kinetic Testing of Nitrate-Based Sodalite Formation Over the Temperature Range of 40 to $100^{\circ}$ C," U.S. DOE Report ORNL/TM-2001, Oak Ridge National Laboratory, UT-Battelle, LLC, Oak Ridge, TN (April 13, 2001).

30 S.V. Mattigod, D.T. Hobbs, K.E. Parker, D.E. McCready, "Precipitation of Aluminum Containing Species in Tank Wastes," U.S. DOE Report PNNL-13881, Pacific Northwest Laboratory, Richland, WA (May, 2002).

31 H. K. Hardy and T. J. Heal, "Report on Precipitation" in Progress in Metal Physics, V 5, B. Chalmers and R. King (Eds.), Pergamon Pres, New York, 324 pp. (1954).

32 P. J. K. Onorato and D. R. Uhlmann, "Nucleating Heterogeneities and Glass Formation", J. Non Crys. Solids, 22, 367-378 (1976).

33 W. D. Robertson and R. S. Bray, "Precipitation Hardening of Copper Alloys," in Precipitation from Solid Solution, American Society for Metals, Cleveland, Ohio, 328390 (1959).

34 J. Burke, The Kinetics of Phase Transformations, Pergamon Press, New York (1965).

35 W.R. Wilmarth “Tank 30H Sample Analysis,” SRT-LWP-2002-00053 (may 29, 2002).

36 W.R. Wilmarth "Tank 30H and 32H Sample Analysis," SRTC-LWP-2002-00058 (June 19, 2002).

37 D.D. Walker and C.J. Coleman, "Densities and Weight\% Solids of Simulated Salt Solutions,” WSRC-TR-91-176 (April 1991).

38 F.M. Pennebaker, C.J. Coleman, M.A. Jones, W.R. Wilmarth, C.M. Jantzen, and D.R. Click, "Evaluation of Warm Acid Strike Treatment for Silicon Analysis in High Level Waste" WSRC-TR-2003-00036 (January 16, 2003).

39 W.R. Wilmarth “Tank 30H and 32H Sample Analysis," SRTC-LWP-2002-00058 (June 19, 2002). 
WSRC-TR-2002-00330, Rev. 0

40 R.F. Swingle and W.R. Wilmarth, “Results of Tank 26F and 46F Samples," SRTLWP-2001-00118 (June, 2001).

41 W.R. Wilmarth, “Tank 26F Sample Analysis,” U.S. DOE Report SRT-LWP-200200033 (March 25, 2002).

42 W.R. Wilmarth “Tank 30H Sample Analysis,” SRT-LWP-2002-00053 (May 29, 2002).

43 W.R. Wilmarth, “Tank 46F Analysis,” U.S. DOE Document SRT-LWP-2002-00081 (August 2, 2002).

44 C.F. Baes, Jr. and R.E. Mesmer, “The Hydrolysis of Cations," John Wiley \& Sons, New York, 489pp. (1976).

45 S. Sjoberg, L.Ohman, N. Ingri, 'Equilibrium and Structural Studies of Silicon(IV) and Aluminum(III) in Aqueous Solution. 11. Polysilicate Formation in Alkaline Aqueous Solution. A Combined Potentiometric and 29Si NMR Study," Acta Chemica Scandinavica , A39, 93-107 (1985).

46 I. Grenthe, et. al., “Chemical Thermodynamics of Uranium,” North Holland, New York (1992).

47 R.H. Busey, R.E. Mesmer, "Ionization Equilibria of Silicic Acid and Polysilicate Formation in Aqueous Sodium Chloride Solutions to $300^{\circ}$ C,' Inorg. Chem., 16, 24442450 (1977).

48 A.S. Russell, J.D. Edwards, and C.S. Taylor, "Solubility and Density of Hydrated Aluminas in NaOH Solutions,” J. of Metals, p.1123-1128 (October, 1955).

49 D.A. Reynolds and D.L. Herting, "Solubilities of Sodium Nitrate, Sodium Nitrite, and Sodium Aluminate in Simulated Nuclear Waste," U.S. DOE Report, RHO-RE-SST14P, Westinghouse Hanford Company, Richland, WA (September, 1984).

50 S.M. Budd, "The Mechanisms of Chemical Reaction Between Silicate Glass and Attacking Agents,” Phys. Chem. Glasses, 2[4], 111-114 (1961).

51 S.V. Mattigod and B.P. McGrail, "Estimating the Standard Free Energy of Formation of Zeolites Using the Polymer Model," Microporous and Mesoporous Materials, 27, 41-47 (1999).

52 R.F. Swingle, “Characterization of the Tank $38 H$ Variable Depth and Core Samples,” U.S. DOE Report WSRC-RP-2001-00574, Rev.0, Westinghouse Savannah River Co., Aiken, SC (May, 2001). 
WSRC-TR-2002-00330, Rev. 0

53 L.N. Oji and W.R. Wilmarth, “Characterization of Tank 46F Core Samples,” U.S. DOE Report WSRC-TR-2001-00519, Rev.0, Westinghouse Savannah River Co., Aiken, SC (February, 2002).

54 C.I. Aponte, "Evaporation Percent Verification for $\mathbf{2 F}$ and $3 H$ Evaporator Systems Samples,” Calculation number X-CLC-G-00018, Rev. 0 (July 30, 2002).

55 D.E. White, W.W. Brannock, and K.J. Murata, "Silica in Hot-Spring Waters," Geochim. Cosmochim. Acta, 10, 27-59 (1956).

56 C.M. Jantzen, "Summary and Status of HEME/HEPA Filter Dissolution for DWPF (Technology Issue 10.1),’ U.S. DOE Report WSRC-RP-89-533 (1989).

57 C.M. Jantzen, R.F. Swingle, A.R. Jurgensen, and F.G. Smith, "Impact of Tank 19F Zeolite Mound on DWPF Vitrification of Sludge Batch 3," U.S. DOE Report WSRCTR-2002-00288, Rev. 0 